UNIVERSIDADE DE SÃO PAULO

FACULDADE DE FILOSOFIA, LETRAS E CIÊNCIAS HUMANAS DEPARTAMENTO DE LETRAS MODERNAS PROGRAMA DE PÓS-GRADUAÇÃO EM ESTUDOS LINGÜÍSTICOS E LITERÁRIOS EM INGLÊS

MARCO ANTÔNIO MARGARIDO COSTA

\title{
DO SENTIDO DA CONTINGÊNCIA À CONTINGÊNCIA DA FORMAÇÃO: UM ESTUDO DISCURSIVO SOBRE A FORMAÇÃO DE PROFESSORES DE INGLÊS
}

São Paulo 


\title{
MARCO ANTÔNIO MARGARIDO COSTA
}

\author{
DO SENTIDO DA CONTINGÊNCIA À \\ CONTINGÊNCIA DA FORMAÇÃO: \\ um estudo discursivo sobre a formação de \\ professores de inglês
}

Tese apresentada ao Programa de PósGraduação em Estudos Lingüísticos e Literários em Inglês do Departamento de Letras Modernas da Faculdade de Filosofia, Letras e Ciências Humanas da Universidade de São Paulo, para a obtenção do título de Doutor em Letras.

Orientadora: Profa. Dra. Marisa Grigoletto

São Paulo

2008 
Serviço de Biblioteca e Documentação da Faculdade de Filosofia, Letras e Ciências Humanas da Universidade de São Paulo

C837 Costa, Marco Antônio Margarido

Do sentido da contingência à contingência da formação: um estudo discursivo sobre a formação de professores de inglês / Marco Antônio Margarido Costa ; orientadora Marisa Grigoletto. -- São Paulo, 2008. $231 \mathrm{f}$.

Tese (Doutorado - Programa de Pós-Graduação em Estudos Lingüísticos e Literários em Inglês. Área de concentração: Estudos Lingüísticos e Literários em Inglês) - Departamento de Letras Modernas da Faculdade de Filosofia, Letras e Ciências Humanas da Universidade de São Paulo.

1. Lingüística aplicada. 2. Análise de discurso. 3. Formação de professores. 4. Língua inglesa (Estudo e ensino). I. Título. 
À Fátima, minha interlocutora primeira, pela paciência, companheirismo e coragem de ter compartilhado as contingências deste desafio. 


\section{AGRADECIMENTOS}

À Profa. Dra. Marisa Grigoletto, pela oportunidade para concretizar este projeto e pelos momentos de leitura, discussão e orientação - fundamentais à sua realização.

À Profa. Dra. Deusa Maria de Souza-Pinheiro Passos e à Profa. Dra. Walkyria Monte Mór, pela leitura e contribuições apresentadas por ocasião do exame de qualificação.

À CAPES, pela concessão da bolsa do Programa de Doutorado no País com Estágio no Exterior (PDEE).

À Unidade Acadêmica de Letras do Centro de Humanidades da Universidade Federal de Campina Grande - PB, pelo afastamento concedido, o que possibilitou a realização do PDEE e conclusão da tese.

Ao Prof. Dr. Thomas S. Popkewitz da University of Wisconsin-Madison (EUA), pelas discussões e orientação durante a realização do estágio junto àquela instituição.

Aos professores membros dos comitês elaboradores das Diretrizes Curriculares.

A todos os alunos e professores que, gentilmente, colaboraram com as entrevistas, tornando esta pesquisa possível.

Aos meus pais, pelo estímulo à educação.

À Fátima, pela determinação, apoio e incentivo nos momentos de incerteza.

À minha família, em especial, minha irmã, Maria do Carmo, pelo estímulo e carinho ao longo do trajeto, bem como à família paraibana "emprestada", em especial, Terezinha (Tina) pelo acolhimento e amparo.

Aos amigos de sempre, pelo apoio: Marcos Moraes, Marcos Ikeda, Vera, Daniela, Socorro, Beto, como também aos novos "encontrados" no percurso deste trabalho, entre eles: Manuela, Edmilson, Paula, Hamurabi e a todos os colegas professores, pelos diálogos acadêmicos e trocas de impressões - essenciais no processo da escrita. 
[...] não se deixa jamais um erro dormir impunemente em paz, pois esse será um meio seguro para que ele perdure; é preciso discernir o que falha não por pretender com isso se amparar definitivamente no verdadeiro (!), mas para tentar avançar tanto quanto se possa em direção à justiça.

[...] - não há dominação sem resistência: primado prático da luta de classes, que significa que é preciso "ousar se revoltar". - ninguém pode pensar do lugar de quem quer que seja: primado prático do inconsciente, que significa que é preciso suportar o que venha a ser pensado, isto é, é preciso "ousar pensar por si mesmo".

Michel Pêcheux. Semântica e discurso: uma crítica à afirmação do óbvio. 
COSTA, Marco Antônio Margarido. Do sentido da contingência à contingência da formação: um estudo discursivo sobre a formação de professores de inglês. São Paulo, 2008. 231 f. Tese (Doutorado em Estudos Lingüísticos e Literários em Inglês) - Faculdade de Filosofia, Letras e Ciências Humanas, Universidade de São Paulo.

\section{RESUMO}

Recentes transformações sociais, muitas das quais ocorridas sob o signo da pós-modernidade, trazem implicações, que são merecedoras de investigação, para o plano educacional, notadamente, no âmbito das propostas curriculares e da formação de professores, segundo reflexões de Giroux (1988), Kincheloe (1993), Silva (1993, 1999), Usher e Edwards (1994), Lindblad e Popkewitz (2004), entre outros. Assim, o objetivo do presente estudo é investigar e analisar o funcionamento do discurso político-educacional e didático-pedagógico da formação de professores de inglês, à luz da Analise de Discurso de orientação pecheutiana e de conceitos de Foucault $(1969,1971,1975,1979)$. Para tanto, examina orientações curriculares, quais sejam: Diretrizes Curriculares Nacionais para a Formação de Professores da Educação Básica, em nível superior, curso de licenciatura, de graduação plena, e, Diretrizes Curriculares Nacionais para os cursos de Letras. Além dessa parte documental, o estudo traz análise de entrevistas com professores e alunos de cursos de formação de professores de inglês em duas instituições de ensino superior, no estado de São Paulo, sendo uma pública e outra privada. A fim de contextualizar e inserir a contribuição do trabalho, o estudo apresenta e examina, primeiramente, algumas pesquisas sobre a formação de professores, de modo geral, bem como sobre a formação de professores de inglês, mais especificamente, além de discussões curriculares recentes em nível mundial e nacional. Diferentemente da modernidade, com a pós-modernidade, determinados conceitos e fundamentos, tais como: o descentramento e a desestabilização das "verdades", a flexibilidade, a ambivalência, a contingência etc., ganham maior evidência. Partindo da premissa que ambas as perspectivas (modernidade e pósmodernidade) habitam o imaginário discursivo educacional, o estudo elege algumas dimensões de ocorrências da ambivalência nesse contexto, observando como o funcionamento discursivo revela uma noção de contingência sempre presente, fruto de uma ambivalência constitutiva da linguagem, dos sentidos, das relações sociais e dos sujeitos aí inseridos, conforme postulam Pêcheux (1975, 1983), Rorty (1989), Bhabha (1994) e Bauman (1991, 2000, 2004). Aponta, também, para materializações lingüísticas e discursivas que sugerem a permanência de ideais modernistas no discurso analisado, explorando seus efeitos para a formação de professores de inglês. Conclui que os efeitos de sentido, destacados no discurso, revelam um adiamento constante da formação de professores de inglês. Finalmente, apresenta alguns aspectos que podem ser valorizados a fim de provocar deslocamentos de sentidos no plano curricular e formativo.

Descritores: Pós-modernidade, Análise de Discurso, Formação de professores de inglês, Diretrizes Curriculares, Contingência. 
COSTA, Marco Antônio Margarido. Do sentido da contingência à contingência da formação: um estudo discursivo sobre a formação de professores de inglês. São Paulo, 2008. 231 f. Tese (Doutorado em Estudos Lingüísticos e Literários em Inglês) - Faculdade de Filosofia, Letras e Ciências Humanas, Universidade de São Paulo.

\begin{abstract}
Recent social changes, many of which have taken place under the name of post-modernity, bring about implications for the educational field, specially, in the curriculum area as well as teacher education, that should be researched, according to Giroux (1988), Kincheloe (1993), Silva (1993, 1999), Usher and Edwards (1994), Lindblad and Popkewitz (2004), among others. Thus, the objective of the present study is to investigate and to analyze the configuration of the political, educational and pedagogical discourse of the English teacher education, based on Pêcheux's theoretical and philosophical concepts of Discourse Analysis along with some of Foucault's concepts $(1969,1971,1975,1979)$. For that purpose, it examines the National Guidelines for Teacher Education Programs and the National Guidelines for Language and Literature Programs. Besides these documents, the study includes analysis of interviews with professors and students of preservice English teacher education programs in two universities, in the state of São Paulo, a public and a private one. First of all, in order to contextualize and to show the contribution of this research, the study presents and examines some research in the area of teacher education, in general. Secondly, it shifts to some specific research on English teacher education. After that, recent debates about curriculum are explored both nationally and internationally. Differently from modernity, with post-modernity some concepts and principles, such as the decentering and the destabilizing of "truths", flexibility, ambivalence, contingency etc., receive greater evidence. Assuming that both perspectives (modernity and post-modernity) inhabit the discursive imaginary of education, the study chooses some dimensions in which the ambivalence is found, observing how the discursive configuration discloses a notion of a contingency always present derived from a constituent ambivalence of language, of meanings, of social relations and of individuals, as pointed out by Pêcheux (1975, 1983), Rorty (1989), Bhabha (1994) and Bauman $(1991,2000,2004)$. The study also focuses on some discursive and linguistic features that suggest modernist ideals in the discourse and explores their effects concerning the English teacher education. The study concludes that the effects evolved in the discourse unfold a constant postponing of the English teacher education. Finally, it presents some aspects that can be considered in order to provoke shifts of meanings in the curriculum field as well as in the teacher education area.
\end{abstract}

Descriptors: Post-modernity, Discourse Analysis, English teacher education, Guidelines, Contingency. 


\section{LISTA DE ABREVIATURAS E SIGLAS}

$\begin{array}{ll}\text { AD } & - \text { Análise de discurso } \\ \text { CNE/CES } & - \text { Conselho Nacional de Educação / Câmara de Educação Superior } \\ \text { CNE/CP } & - \text { Conselho Nacional de Educação / Conselho Pleno } \\ \text { DCF } & - \text { Diretrizes Curriculares Nacionais para a Formação de Professores da } \\ & \text { Educação Básica } \\ \text { DCL } & - \text { Diretrizes Curriculares para os cursos de Letras } \\ \text { ELT } & - \text { English language teaching } \\ \text { FD } & - \text { Formação discursiva } \\ \text { GQT } & - \text { Gestão pela Qualidade Total } \\ \text { LDB } & - \text { Lei de Diretrizes e Bases } \\ \text { LE } & - \text { Língua estrangeira } \\ \text { MDCF } & - \text { Membro do comitê elaborador das DCF } \\ \text { MDCL } & - \text { Membro do comitê elaborador das DCL } \\ \text { MEC } & - \text { Ministério da Educação } \\ \text { NCLB } & - \text { No child left behind } \\ \text { PCN } & - \text { Parâmetros Curriculares Nacionais } \\ \text { TFA } & - \text { Teach for America } \\ \text { Inep } & - \text { Instituto Nacional de Estudos e Pesquisas Educacionais Anísio Teixeira } \\ \text { PNUD } & - \text { Programa das Nações Unidas para o Desenvolvimento } \\ \text { ANPEd } & - \text { Associação Nacional de Pós-Graduação e Pesquisa em Educação } \\ \text { UNESCO } & - \text { Organização das Nações Unidas para a Educação, a Ciência e a Cultura } \\ \text { TIC } & - \text { Tecnologias da informação e da comunicação } \\ & \end{array}$




\section{LISTA DE SÍMBOLOS}

\begin{tabular}{|c|c|c|}
\hline Sinais & & Ocorrências \\
\hline ( ) & - & Incompreensão de palavras ou segmentos \\
\hline (hipótese) & - & Hipótese do que se ouviu \\
\hline / & - & Truncamento \\
\hline MAIÚSCULA & - & Entonação enfática \\
\hline$:::$ & - & Prolongamento de vogal e consoante (como s, r) \\
\hline- & - & Silabação \\
\hline$?$ & - & Interrogação \\
\hline$\ldots$ & - & Qualquer pausa \\
\hline ((minúscula)) & - & Comentários descritivos do transcritor \\
\hline “” & - & Fala relatada \\
\hline
\end{tabular}

\section{OUTROS SÍMBOLOS}
A1
- Aluno 1
P1
- Professor 1 


\section{SUMÁRIO}

INTRODUÇÃO

PARTE I - CONTEXTUALIZANDO O PERCURSO INVESTIGATIVO .. 6

CAPÍTULO 1 - PÓS-MODERNIDADE, EDUCAÇÃO E CONTINGÊNCIA . 7

1.1 A pós-modernidade como pano de fundo da pesquisa ...................... 7

1.2 Do sentido da contingência à contingência da formação .................... 16

CAPÍTULO 2 - FORMAÇÃO DE PROFESSORES.......................................... 26

2.1 Esboçando reflexões sobre a formação de professores ....................... 26

2.2 A formação específica: alguns percursos já trilhados ........................ 34

2.3 Situando a contribuição da nossa pesquisa ...................................... 42

CAPÍTULO 3 - O CURRÍCULO COMO ESPAÇO DA AMBIVALÊNCIA ... 45

3.1 Reformas Curriculares: variações de um mesmo sentido? .................. 46

3.2 A transferência de deveres e os deslizamentos de sentidos das reformas curriculares ............................................................... 48

3.3 Algumas discussões no Brasil ...................................................... 56

3.4 Diretrizes Curriculares: suas condições de produção ......................... 60

3.5 Sintetizando as reflexões ............................................................... 68

3.6 Reformas Curriculares: para onde nos encaminhamos? .................. $\quad 72$

PARTE II - INVESTIGANDO O DISCURSO DA FORMAÇÃO DE PROFESSORES ….......................................................................... 78

CAPÍTULO 4 - DIRETRIZES CURRICULARES......................................... 79

4.1 Adequar-se para mudar ou mudar para adequar-se? ......................... 82

4.2 A "flexibilidade" como palavra de ordem ........................................ 87

4.3 Entre o necessário e o contingente ..................................................... 91

4.4 Entre a teoria e a prática .................................................................... 96

4.5 Avaliar ou estigmatizar? .............................................................. 101

4.6 Algumas decorrências ..................................................................... 103

CAPÍTULO 5 - O IMPOSSÍVEL DE DIZER: O DISCURSO DA FORMAÇÃO DE PROFESSORES DE INGLÊS (INSTITUIÇÃO 1) ............... 107

5.1 Efeitos de instabilidade e indeterminação no discurso da formação ... 108

5.2 Modos de constituição de um pacto tácito sobre a formação .............. 127

5.3 A linearização de procedimentos e deveres ....................................... 142

5.4 Considerações acerca da Instituição 1 ............................................... 157

CAPÍTULO 6 - AS DUAS FACES DO TRAUMATRÓPIO: O DISCURSO DA FORMAÇÃO DE PROFESSORES DE INGLÊS (INSTITUIÇÃO 2) ........ 
6.1 Em busca do amadurecimento necessário ........................................ 163

6.2 A incerteza das escolhas profissionais .......................................... 174

6.3 A seleção e o residual ..................................................................... 180

6.4 A fragmentação institucional ............................................................ 188

6.5 "A sociedade de segredo" .................................................................. 194

6.6 Considerações acerca da Instituição 2 _............................................ 207

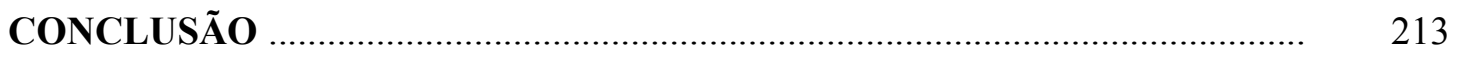

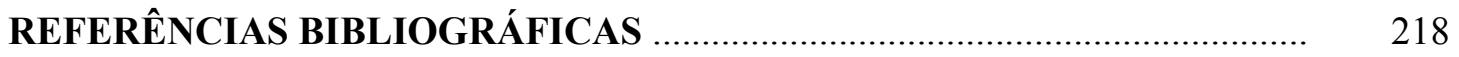

ANEXOS

Anexo 1 - Diretrizes Curriculares Nacionais para a Formação de Professores da Educação Básica, em nível superior, curso de licenciatura, de graduação plena ....... Anexo 2 - Diretrizes Curriculares para os cursos de Letras .....................................

Anexo 3 - Transcrição das entrevistas com os professores e alunos - amostragem da Instituição 1

Anexo 4 - Transcrição das entrevistas com os professores e alunos - amostragem da Instituição 2 


\section{INTRODUÇÃO}

A proposta do presente trabalho nasce da crença de que os cursos de formação de professores merecem grande atenção se temos em mente a necessidade de formar educadores que assumam um papel crítico e reflexivo de intelectual transformador, conforme argumenta Giroux (1988/1997) ${ }^{1}$. Isso nos faz lembrar relevantes trabalhos sobre esse tema como os de Severino (1994), salientando que, para formar um educador, não se pode perder de vista propósitos que englobem a formação técnico-científica, política e filosófica. Acreditando, portanto, na importância dos cursos de formação de professores e, compartilhando da afirmação de Guimarães (2004, p. 19) de que "conhecemos pouco ou praticamente desconhecemos o que ocorre no interior dos nossos cursos de formação de professores", dirigimos nosso olhar especificamente para a formação do professor de inglês.

Nossa vivência, como professor de inglês, em meio ao cotidiano escolar de instituições públicas estaduais e escolas de idiomas nos colocou frente a características específicas desses núcleos de trabalho, cujo painel, embora parcial, das dificuldades, certezas e perspectivas inerentes a esses universos nos foi descortinado. A partir de uma outra perspectiva, como professor de um curso de formação de professores de inglês, pudemos refletir sobre as possibilidades profissionais oferecidas pelo mercado para os futuros professores de inglês desse curso, assim como sobre sua preparação para a vida profissional. Apesar de alguns alunos manifestarem interesse por outras áreas de trabalho (tradução, revisão etc.), nossa preocupação foi, e continua sendo, com a formação do professor de inglês como educador. Dessa forma, os dilemas, impasses e dificuldades que essa tarefa suscita nos impulsionaram a investigar esse processo de formação.

Giroux (1997) nos lembra que as propostas dos programas de cursos de formação de professores têm o objetivo de criar educadores que sirvam aos interesses do Estado, mantendo, portanto, o status quo. Essa constatação nos leva a acreditar na complexidade da questão da formação do professor de inglês em virtude da rede intricada de relações políticas, sociais, culturais e ideológicas que ela envolve. Desse modo, propomos, neste trabalho,

\footnotetext{
${ }^{1}$ Ao longo do trabalho, na primeira referência a obras estrangeiras, indicaremos, quando for o caso, duas datas; a primeira refere-se à publicação do original e, a segunda, refere-se à obra consultada da qual foi retirada a citação. Nas demais ocorrências, será indicada apenas a data da obra consultada.
} 
investigar os processos de representação ${ }^{2}$ da formação do professor de inglês a partir da observação de contextos educacionais em duas instituições de ensino superior, no estado de São Paulo, sendo uma pública e outra privada.

A escolha das universidades deveu-se, primeiramente, ao fato de termos lecionado a disciplina de língua inglesa em uma universidade privada, a partir de onde nossas inquietações - muitas das quais fazem parte desta pesquisa - foram geradas. A opção pela investigação também em uma universidade pública teve como base a importância do seu papel na formação de professores e no desenvolvimento de pesquisas, além do fato de este estudo estar vinculado a um programa de pós-graduação de uma universidade pública.

O corpus do trabalho foi composto por 25 entrevistas $^{3}$ (14 com professores em exercício nos cursos pesquisados e 11 com alunos em formação desses mesmos cursos ${ }^{4}$ ), além de análise documental. Para essa parte da pesquisa, recorremos a documentos emitidos pelo Conselho Nacional de Educação, a saber: Diretrizes Curriculares Nacionais para a Formação de Professores da Educação Básica, em nível superior, curso de licenciatura, de graduação plena e as Diretrizes Curriculares para os cursos de Letras. ${ }^{5}$ A fim de compreender as condições de produção ${ }^{6}$ de tais documentos, entrevistamos, ainda, dois membros das equipes que os elaboraram; sendo um das Diretrizes Curriculares para a Formação de Professores, e outro, das Diretrizes Curriculares para os cursos de Letras.

Propomo-nos a analisar o presente corpus à luz da Análise de Discurso (AD) de orientação pecheutiana, como também mobilizamos conceitos de Foucault que julgamos relevantes para nossa investigação. Acreditamos que essa perspectiva teórica e filosófica nos ajuda a pensar sobre a maneira como a materialidade lingüística reflete o discurso (e, por conseguinte, a ideologia), revelando a aparente unidade dos discursos, ou conforme propõe Orlandi (1999/2002, p. 72$)^{7}$, uma das precursoras da AD no Brasil, a tarefa do analista é ver

\footnotetext{
${ }^{2}$ Utilizamos esse termo no sentido em que é trabalhado por Hall (1997), isto é, como uma imagem produzida no discurso pelo sujeito.

${ }^{3}$ As entrevistas foram realizadas individualmente e gravadas em áudio.

${ }^{4}$ Descreveremos o contexto das instituições pesquisadas na Parte II, Capítulos 5 e 6 , deste trabalho.

${ }_{6}^{5}$ Os documentos encontram-se transcritos integralmente como Anexos 1 e 2, respectivamente.

${ }^{6}$ Mobilizamos a noção de condições de produção do discurso no sentido em que é trabalhado por Orlandi (1999/2002, p. 30). Essas condições de produção podem ser consideradas em sentido estrito (contexto imediato dos sujeitos e da situação), daí a noção de circunstâncias da enunciação, como também em sentido amplo. Nesse caso, as condições de produção envolvem também o contexto sócio-histórico e ideológico no qual um discurso é produzido.
} 
"como o discurso se textualiza". Para essa pesquisadora, a AD "teoriza a interpretação, isto é, coloca a interpretação em questão" (2002, p. 25). Sendo assim, a partir do texto, deve-se buscar compreender o processo de produção de sentidos que a ausência de transparência da língua(gem) possibilita resgatar. Sobre esse aspecto, vale destacar reflexão de Brandão (1997/1998, p. 19), que afirma que a AD concentra-se no texto, considerando a sua opacidade, levando em conta "o modo de funcionamento lingüístico-textual dos discursos, as diferentes modalidades do exercício da língua num determinado contexto histórico-social de produção”.

Desse modo, faz-se necessário apresentar, brevemente, algumas noções e conceitos da $\mathrm{AD}$ que compõem o painel teórico de referência que fundamenta nossa análise. Iniciamos com a noção de sujeito, e por meio dela, a de ideologia. De acordo com Pêcheux (1975/1997b, p. 133), o sujeito é constituído por um processo de "imposição/dissimulação" que o situa, outrossim, cria um significado para ele do que ele é e, ao mesmo tempo, o torna assujeitado a essa situação, constituindo, dessa forma, uma ilusão de que ele "funciona" por si mesmo. Ou seja, não se trata de um sujeito dotado de unicidade e consciência com domínio sobre seu dizer e sobre o sentido desse dizer. Disso decorre a noção de ideologia que, para a $\mathrm{AD}$, é uma formação imaginária, uma condição necessária que faz com que o sujeito e os sentidos se constituam da maneira que se apresentam. É por meio dessa ideologia (imagem construída) que o sujeito se vê, vê o outro, vê o objeto do qual fala e, notadamente, vê o lugar de onde ele e o outro falam. Enfim, é uma imagem que se constrói das "reais" condições de existência. Conforme explicita Orlandi (1992/1997, p. 17), Pêcheux vê o discurso como "o lugar de contato entre língua e ideologia".

Buscamos em Foucault, cujas reflexões, segundo Brandão (1991/1996, p. 31), "colocam diretrizes para uma análise do discurso", a noção de formação discursiva (FD). Esse conceito estabelece que o discurso é constituído por uma "dispersão" de enunciados. Isso auxilia o analista de discurso a perceber formulações diversas conjugando-se a fim de constituir um "novo" discurso, ou seja, um "novo" conjunto de enunciados. Conforme apontam Charaudeau e Maingueneau (2004), foi Pêcheux o responsável por trazer a noção de FD para a AD. Para ele, toda formação social, isto é, uma relação entre as classes sociais, é constituída de posições políticas e ideológicas que se organizam em uma ou várias formações

\footnotetext{
${ }^{7}$ Ao longo do trabalho, na primeira referência a obras nacionais, indicaremos, quando for o caso, duas datas; a primeira refere-se à primeira edição, e, a segunda, refere-se à edição consultada da qual foi retirada a citação. Nas demais ocorrências, será indicada apenas a data da obra consultada.
} 
discursivas interligadas. São essas formações discursivas que estabelecem "o que pode e deve ser dito" a partir de uma posição dada em uma determinada conjuntura (PÊCHEUX, 1997b, p. 160). Para formular essa teoria, Pêcheux parte do princípio de que o sentido de uma palavra não existe "em si mesmo". Decorre daí a noção de que não há um sentido fixo para as palavras, ele é determinado pela conjuntura sócio-histórica na qual elas são produzidas. $\mathrm{O}$ exterior lingüístico (condições de produção do discurso) também afeta a linguagem, isto é, os sentidos das palavras são produzidos/determinados pela história. É por isso que para ele, o discurso é efeito de sentido entre locutores. Com isso, para a $\mathrm{AD}$, a linguagem é vista como produto histórico-social, sendo seu modo de funcionamento fator importante para uma perspectiva discursiva. De acordo com as palavras de Orlandi (1983/2006, p. 117), "esse modo de funcionamento não é integralmente lingüístico, uma vez que dele fazem parte as condições de produção, que representam o mecanismo de situar os protagonistas e o objeto do discurso".

Encontramos, ainda, em Pêcheux (1997b, p. 162), a exploração de um conceito extremamente importante para a AD: o interdiscurso. Sua tese é de que as formações discursivas são constituídas em um espaço no qual figuram formações ideológicas diversas que estão permanentemente em relação de "desigualdade-contradição-subordinação", formando um "todo complexo com dominante". Em outras palavras, é por meio do interdiscurso que podemos identificar algo que já foi dito antes, em um local diferente, em um momento diferente. Devolvendo a palavra a Orlandi (2002), o interdiscurso é, desse modo, a memória do dizer. O presente trabalho se inscreve, portanto, nessa linha teórica da $\mathrm{AD}$ que acabamos de esboçar. Outros conceitos da $\mathrm{AD}$ serão explicados à medida que forem mobilizados na análise.

Este estudo está organizado em duas partes, além da Conclusão, contendo três capítulos em cada parte. A Parte I, à guisa de uma apresentação das condições de produção da tese, discorre, no Capítulo 1, sobre os fundamentos basilares que nos direcionaram para a elaboração da nossa tese, que também será expressa juntamente com as questões de pesquisa. No Capítulo 2, apresentamos resumos de alguns trabalhos cuja preocupação está voltada para a formação de professores/de professores de língua inglesa e analisamos esse levantamento bibliográfico, com o objetivo de oferecer um painel dos estudos realizados nessa área e situar esta pesquisa nesse universo de estudo. No último capítulo da primeira parte, exploramos trabalhos e discussões que abordam especificamente a questão do currículo escolar. 
Incluímos, ainda, nesse Capítulo 3, análise das entrevistas com professores que participaram da elaboração das Diretrizes Curriculares.

No Capítulo 4, da Parte II, analisamos documentos que tratam dos cursos de formação de professores (Diretrizes Curriculares Nacionais para a Formação de Professores da Educação Básica, em nível superior, curso de licenciatura, de graduação plena e Diretrizes Curriculares para os cursos de Letras). Expomos reflexões acerca de alguns aspectos que esse corpus suscita, tais como: perfil dos formandos, competências e habilidades específicas a serem desenvolvidas durante o período de formação, conteúdos curriculares, estruturação do curso e formas de avaliação. No Capítulo 5, analisamos o discurso da formação de professores, a partir das entrevistas realizadas com professores e alunos de um curso de formação de professores de inglês de uma universidade privada, com o objetivo de compreender, nesse discurso didático-pedagógico, as representações acerca da formação de professores de língua inglesa. Finalmente, no Capítulo 6, com o mesmo objetivo do capítulo anterior, o enfoque volta-se para professores e alunos de um curso de formação de professores de inglês de uma universidade pública. Acrescentamos que, por razões metodológicas, nossas questões de pesquisa serão apresentadas no próximo capítulo, bem como a tese que norteia o presente trabalho. 


\section{PARTE I}

\section{CONTEXTUALIZANDO O PERCURSO INVESTIGATIVO}

O papel de um pesquisador não é dizer aos outros o que têm de fazer. Quem dá aos pesquisadores, na qualidade de intelectuais, esse direito? Ao examinar

o "direito" do intelectual de dizer ao restante da sociedade o que fazer, é importante lembrar todas as profecias, promessas, injunções e programas que os intelectuais têm conseguido formular nos dois últimos séculos, cujos efeitos podemos agora observar. $O$ trabalho dos pesquisadores não é moldar

a vontade política dos outros. Em vez disso, é importante que cada intelectual, através das análises realizadas no seu próprio campo, questione incessantemente o que é postulado como auto-evidente, perturbe os hábitos mentais das pessoas, descentralize a maneira como fazem e pensam as coisas, questionem o que é familiar e aceito, examinem regras e instituições e, baseado nessa reproblematização (em que realiza uma tarefa específica como intelectual), participe da formação de uma vontade política (na qual ele tem um papel a desempenhar como cidadão).

Thomas S. Popkewitz (parafraseando Michel Foucault). Lutando em defesa da alma: a política do ensino e a construção do professor. 


\title{
CAPÍTULO 1
}

\section{PÓS-MODERNIDADE, EDUCAÇÃO E CONTINGÊNCIA}

\begin{abstract}
A mais pungente e menos respondível das questões dos nossos tempos de modernidade líquida não é "o que fazer?" (para tornar o mundo melhor ou mais feliz), mas "quem vai fazê-lo?"

Zygmunt Bauman. Modernidade líquida.
\end{abstract}

Antes de iniciarmos nossa investigação, faz-se necessário lançarmos um olhar para uma questão que é essencial para este trabalho e que forma o "pano de fundo" desta pesquisa: a pós-modernidade. Objeto de várias reflexões no meio acadêmico, esse tema tornou-se tônica entre pensadores e teóricos nas últimas décadas, sendo tratado por muitos deles como um prolongamento da modernidade ou como um outro modo de relação com ela. A partir do recorte $^{8}$ que faremos, veremos que a definição do termo é volátil. Contudo, frente a tal quadro, um ponto é irrefutável: estamos diante de uma mudança de paradigma que traz implicações para a vida em sociedade, em diversos níveis (político, econômico, cultural, educacional etc.). Por essa razão, justificamos a referência a alguns conceitos teóricos sobre a pós-modernidade a fim de contextualizar nosso trabalho, revelar a formulação de nossas questões de pesquisa, que enunciaremos ao final desta exposição, bem como a tese que buscaremos comprovar.

$\mathrm{Na}$ primeira seção, apresentaremos alguns conceitos sobre a pós-modernidade. Mostraremos algumas perspectivas, enfatizando suas definições e implicações em diversas áreas da sociedade, para, por conseguinte, direcionar nosso foco para o plano educacional campo de nosso interesse. Na segunda seção, como decorrência da primeira, abordaremos a questão da contingência, idéia fulcral da pesquisa, na qual a tese está fundamentada. Após ser apresentada, proporemos nossas questões de pesquisa que constituirão os mecanismos propulsores deste estudo.

1.1 A pós-modernidade como pano de fundo da pesquisa

\footnotetext{
${ }^{8}$ Não é nosso objetivo explorar exaustivamente conceitos de pós-modernidade, mas sim fornecer um painel das discussões, embora parcial, para esclarecer a gênese da nossa tese.
} 
De uma perspectiva histórica, Anderson (1998/1999, p. 9-10) relata que a idéia de um pós-modernismo surgiu, primeiramente, na década de 1930, no mundo hispanófono. Cunhado para designar uma categoria estética, deve-se sua criação ao poeta Frederico de Onís, que empregou o termo para fazer referência a "um refluxo conservador dentro do próprio modernismo". No entanto, após esse primeiro momento, o uso do termo não teve muita repercussão, voltando a emergir somente em 1954, com o historiador inglês Arnold Toynbee, para descrever uma época que teve início com a guerra franco-prussiana. Conforme Anderson (1999, p.11), essa "idade pós-moderna" foi caracterizada pela "ascensão de uma classe operária industrial no Ocidente e pelo convite de sucessivas intelligentsias fora do Ocidente a dominar os segredos da modernidade e voltá-los contra o mundo ocidental".

Rouanet (1989) parte do princípio de que a pós-modernidade, em seu sentido lato, é um questionamento da modernidade. Comenta que a expressão é aplicada em diversas áreas, a saber: na arquitetura, na literatura, na pintura, na ciência, na filosofia, na economia, na política e na sociedade, de modo geral. Para esse cientista político, existe uma "consciência de ruptura" com o modernismo, entretanto, é necessário esclarecer se há, também, com essa consciência, uma "ruptura real" com o movimento. Essa é a questão que investiga em seu ensaio, refletindo sobre a dimensão do cotidiano, da economia e da política, no âmbito social da pós-modernidade, para, em seguida, abordar o âmbito cultural, analisando questões como: o saber (a ciência e a filosofia), a moral e a arte. Sua conclusão é de que não há ruptura com a modernidade. Argumenta que as tendências da pós-modernidade são prolongamentos do modernismo. Não é nossa intenção detalhar cada segmento analisado por esse pensador, no entanto, apresentamos suas reflexões sobre a dimensão do cotidiano (âmbito social) e acerca da arte (no âmbito cultural) para mostrar, brevemente, seu percurso analítico. Na visão desse cientista político, características do cotidiano pós-moderno, tais como: a estetização da mercadoria, a predominância da informação, o hedonismo e o consumismo generalizado, a extinção dos espaços de intimidade, entre outros, são familiares, pois correspondem a características modernas (preconizadas pela própria modernidade). Entende também que o deslumbramento ou a aversão atual pela informática tem a mesma proporção da admiração (ou aversão) pela invenção da máquina, no início do século XX. Ambos simbolizam “o poder técnico sobre a natureza e uma forma nova de ordenar a vida social" (1989, p. 258). No plano da arte (âmbito cultural), o ensaísta declara que também não distingue um corte com o modernismo. Para ele, características "pós-modernistas" na arte como: jogo, processo, 
anarquia, disjunção, abertura, não passam de tendências modernistas de movimentos como o dadaísmo e o surrealismo.

Concluindo seu ensaio, de modo a responder sua questão inicial se existe uma ruptura de fato ou apenas a consciência de ruptura, Rouanet (1989, p. 268) advoga que o homem contemporâneo está cansado da modernidade por associar a ela "males" como Auschwitz, Hiroshima, ameaça de aniquilação atômica, ressurreição de fanatismos políticos e religiosos, degradação dos ecossistemas. Isso causa uma atitude de rejeição à modernidade, que faz com que exista uma convicção de que há uma transição de paradigma. Para ele, é o desejo de ruptura que leva à crença de que a ruptura existe de fato. Conclui, dessa forma, que "o prefixo 'pós' tem muito mais o sentido de exorcizar o velho (a modernidade) que de articular o novo (o pós-moderno)" (p. 269). Com isso, entende que existe apenas uma consciência de ruptura, ao mesmo tempo, falsa, pois ainda não ocorreu, e verdadeira, porque remete às "deformações da modernidade". Conforme sua visão, a pós-modernidade é então um "mal-estar da modernidade", "é a tentativa de reagir às patologias da modernidade através de uma fuga para frente, renunciando a confrontar-se concretamente com os problemas da modernidade" (p. 269). A partir da sua discussão, propõe o termo "neomoderno", por acreditar que ele ilustra mais claramente essa atitude de contestação da modernidade e não um rompimento, conforme o prefixo "pós" sinaliza.

Para Peters, (2000), não existe definição única e fechada para o termo pósmodernidade, pois ela tem mudado, historicamente, de acordo com a sua utilização por estudiosos que buscam torná-la teoricamente produtiva. Inicialmente, apresenta dois significados gerais para o pós-modernismo, na sua relação com o termo "modernismo": no primeiro, é utilizado esteticamente para designar as transformações nas artes, ocorridas após o modernismo ou em reação a ele; no segundo, o termo é usado em um sentido histórico e filosófico, fazendo referência a um período ou a um ethos (a pós-modernidade). Argumenta também que o termo pós-modernismo não deve ser confundido com pós-estruturalismo, pois ambos apresentam diferenças de ordem teórica e histórica. A fim de reforçar essas diferenças, esse teórico da educação postula que, do ponto de vista histórico, o pós-modernismo se desenvolveu a partir do contexto do modernismo estético, da história ocidental da arte denominada avant-garde, sobretudo da inovação e do experimentalismo artísticos que marcaram movimentos como o cubismo, o dadaísmo e o surrealismo. Acrescenta ainda que o pós-modernismo relaciona-se com o processo de abstração - marca de movimentos como o 
suprematismo, o construtivismo, o expressionismo abstrato, o minimalismo e com o abandono da preocupação estética. Peters conclui, então, que o pós-modernismo não significa o rompimento com o modernismo, mas um outro modo de relação com ele.

Podemos ampliar essa reflexão, se pensarmos sobre a contribuição de Lyotard (1979/1986) e no modo que formula o conceito de pós-moderno. A definição elaborada para o termo, por esse pensador francês, como sendo uma atitude de "incredulidade em relação aos metarrelatos", ou grandes narrativas da humanidade, figura vastamente na literatura voltada para reflexões sobre a pós-modernidade. Esses metarrelatos são versões de histórias (pessoais, políticas, morais, religiosas etc.) que são transmitidas pelas culturas a fim de legitimá-las. Segundo essa perspectiva, esses grandes relatos perderam a credibilidade, instaurando-se, com isso, um movimento de deslegitimação do conhecimento. Ou seja, a característica da modernidade de tornar o conhecimento objetivo, fixo e imparcial, não encontra respaldo em uma época em que o questionamento, a incredulidade, a visão caleidoscópica do conhecimento ${ }^{9}$ desestabiliza conceitos e, por conseqüência, aspectos da vida em sociedade. Conforme argumenta Peters (2000), a contribuição de Lyotard para essa discussão sobre a pós-modernidade foi unir elementos que eram considerados separadamente: o econômico (pós-industrial) e o cultural (pós-moderno).

Detenhamos-nos, a partir deste momento, em algumas análises que fazem articulações com a educação. Segundo Kiziltan, Bain e Cañizares ${ }^{10}$ (1993), a única característica que une vários pensadores sobre a questão da pós-modernidade é o fato de que as sociedades ocidentais estão às voltas com "dramáticas e perturbadoras" alterações. Primeiramente, com relação à economia, argumentam que o capitalismo industrial transitou para o capitalismo de consumo, a produção de bens deslizou para a produção de informação. Quanto à distribuição dos empregos, as mudanças transformaram a área industrial e de manufatura em área de serviços. De modo geral, postulam que a pós-modernidade trouxe a "internacionalização da produção e da distribuição de serviços e informação e a consolidação das forças de produção sob o controle das empresas multinacionais e das estratégias de comunicação global” (1993, p. 206). Os autores desse estudo voltam-se, então, para o plano educacional, julgando ser de

\footnotetext{
${ }^{9}$ Emprestamos expressão de McLennan (1992/[1996?], p. 333), que formula a noção de conhecimento na pósmodernidade como "a kaleidoscopic array of limited and transient language games".

${ }^{10}$ Professores do Departamento de Cultural Foundations of Education and Curriculum, School of Education, Syracuse University, Syracuse, NY (SILVA, 1993, p. 232).
} 
extrema importância pensar sobre essa questão na pós-modernidade. Voltemo-nos à justificativa apresentada:

Primeiramente, o pós-moderno significa a (des)ordem do dia e assim exige esse repensar. É nesse sentido que o pós-moderno condiciona as práticas educacionais cotidianas, molda as questões curriculares (p. ex., o currículo central, o cânon, o multiculturalismo etc.), abala padrões e fronteiras convencionais e, ao final, leva à ansiedade (p. ex., o movimento da volta ao ensino dos fundamentos, o (an)alfabetismo cultural, a crise de autoridade, a falta de disciplina etc.). O pós-moderno, pela primeira vez na história do Ocidente, ameaça radicalmente a possibilidade da educação pública, ao revelar a parcialidade inerente da educação e expor a fragilidade e falta de substância de seus pressupostos epistêmicos e metafísicos. Como tal, o pósmoderno é a moldura de um conjunto singular de circunstâncias que constantemente ameaçam a educação com a perda de sua importância cultural tradicional e de sua legitimidade. (KIZILTAN; BAIN; CAÑIZARES, 1993, p. 209).

Com isso, nesse ensaio, a partir de conceitos de Foucault (discurso, formação discursiva) e de Lyotard (condição pós-moderna ${ }^{11}$, metanarrativas), os autores olham para a noção de educação pública como uma formação discursiva, possuindo, portanto, seu "regime de verdade". A partir da contribuição de Lyotard, sustentam, então, a necessidade de se pensar sobre a desestabilização das metanarrativas da modernidade que a pós-modernidade impõe, considerando aí a educação, principalmente a educação pública. Para tanto, recapitulam reflexões que a condição pós-moderna rende à educação, sintetizando hipóteses ${ }^{12}$, que, em última análise, direcionam a educação pública para a performatização (preparo para assumir atribuições específicas na sociedade) ou anarquia. Na tentativa de rever essa "condição" da educação na perspectiva pós-moderna, propõem uma reformulação do conceito de iluminismo, a partir do interior de uma perspectiva pós-moderna, isto é, separando-o do discurso da modernidade. Com isso, chegam ao princípio da "atitude-limite", que é o termo que Foucault emprega para designar o modo "reflexivo e transgressivo" de ser no mundo, ou seja, o homem em constante problematização com seu presente, sua história e sua constituição. Essa perspectiva foucaultiana, para os autores, traz para a noção de iluminismo a dissimilaridade, o descentramento, o adiamento, a dúvida, a multiplicidade e fluidez do eu, do

\footnotetext{
${ }^{11}$ No sentido de incredulidade diante das grandes narrativas.

12 São três as hipóteses apresentadas: a primeira delas, sugere como um dos efeitos constitutivos mais significativos a noção de conhecimento científico como objetivo, divorciado das contingências das perspectivas e atividades humanas. Na segunda hipótese, a crise contemporânea da educação pública pode ser atribuída ao declínio das metanarrativas, e, por conseguinte, à desintegração do discurso da educação pública. Finalmente, a terceira hipótese está centrada na crise do domínio institucional da educação pública vinculada ao critério de performatividade, ou seja, na prescrição e delimitação de papéis e capacidades dos atores e das práticas educacionais (KIZILTAN; BAIN; CAÑIZARES, 1993, p. 215).
} 
conhecimento e do mundo. Assim sendo, fazendo referência a Foucault, concluem que "uma idéia de educação pública que corporifique o princípio da atitude-limite tem que implicar nada menos do que isso: que 'a possibilidade de não mais ser, fazer, ou pensar o que somos, seja separada da contingência que nos fez o que somos" (KIZILTAN; BAIN; CAÑIZARES, 1993, p. 221). Entendemos que o "modo transgressivo de pensamento" que esses pesquisadores sugerem contempla, portanto, a incerteza, a instabilidade e a dúvida daquilo que poderá vir a ser ou a ocorrer.

De modo similar, as considerações de Usher e Edwards (1994) abrangem questões educacionais. A princípio, argumentam que não é tarefa fácil definir o termo pósmodernidade. Acreditam que qualquer tentativa de formulação de um sentido fechado, estável e único seria contrária à noção de pós-moderno, pois implicaria aí uma totalização - atitude que a pós-modernidade rejeita. Postulam que a pós-modernidade faz da incerteza, da ausência de uma perspectiva central e do significado "flutuante", fenômenos característicos desse contexto. Os autores fazem uma distinção entre os termos "pós-modernidade", "pósmodernismo" e "momento pós-moderno". Para eles, esse último descreve uma atitude de aceitação do pluralismo e da diferença, enquanto que pós-modernismo designa as mudanças ocorridas na produção, propagação e consumo da cultura. Quanto à pós-modernidade, esses teóricos analisam que o termo expressa algo que substitui ou sucede a modernidade. Existe com a pós-modernidade uma perspectiva que:

[...] describes a world where people have to make their way without fixed referents and traditional anchoring points. It is a world of rapid change, of bewildering instability, where knowledge is constantly changing and meaning "floats" without its traditional teleological fixing in foundational knowledge and the belief in inevitable human progress. (USHER; EDWARDS, 1994, p. 10).

Não nos valeremos da distinção entre "pós-modernidade", "pós-modernismo" e "momento pós-moderno" para os propósitos deste trabalho, pois o aspecto que nos interessa é que, independentemente da terminologia adotada, uma questão se impõe: a representação como um "mecanismo" de construção da realidade. Dito de outro modo, nesse momento da pós-modernidade no qual vivemos, os conceitos, as imagens, as instituições (de modo geral) se desfazem ou se mostram como construções que possuem prazo de validade definido. Esse é um aspecto que nos interessa quando voltamos o olhar para o plano educacional. Ou seja, transitamos de um momento em que a totalidade, as certezas, a normatização e a organicidade 
governavam os conceitos e as relações sociais (incluindo aí aspectos políticos, econômicos, culturais etc.), para um momento de reformulação de concepções, do surgimento das incertezas, da parcialidade, da ressignificação de conceitos e, conseqüentemente, das relações na vida social. Como (re)pensar o papel da educação, da formação de professores, visões do que seja educar ou formar professor, nesse ambiente labiríntico ${ }^{13}$ ?

Em momento posterior no estudo, Usher e Edwards (1994) dirigem o olhar para a questão da educação, afirmando que, por estar ela vinculada ao ideal iluminista da modernidade, sua adequação nesse ambiente pós-moderno parece não encontrar morada. Entendem que, se o papel da educação está fundamentado na noção de formação de indivíduos capazes de reconhecer suas potencialidades para se tornarem autônomos e com aptidão para exercerem suas individualidades, diante de um quadro que assume a ambivalência e a descentralização das subjetividades (partindo da premissa que "pósmoderno" implica pluralidade e diferença), a educação é afetada na sua estrutura epistemológica. Sendo assim, a pós-modernidade coloca desafios para a educação na questão curricular, nos seus métodos e objetivos. Podemos concluir, com isso, que esses desafios se estendem também para a questão da formação de professores. No final do estudo, os autores concluem que não há considerações definitivas sobre a questão da pós-modernidade; a única certeza é o embate com as incertezas e o desafio é, portanto, aprender a lidar com elas.

Sobre essas articulações com o campo educacional, lembramo-nos, ainda, de Kincheloe (1993/1997). O autor advoga que uma educação pós-moderna recusa-se a fornecer elementos prontos de modo genérico, aplicáveis a todos os contextos. Professores e alunos aprendem a produzir seu próprio conhecimento - sempre visto como provisório, pois as verdades e crenças são sempre questionadas. Ao contrário da linearidade do pensamento moderno, nesta perspectiva, os eventos são múltiplos e agem uns sobre os outros de maneira simultânea. Assim, os professores passam a compreender as relações da escola com a sociedade, o que faz com que o contexto seja extremamente valorizado. As verdades não são únicas e aplicáveis a todas as situações. A vida e o conhecimento de cada aprendiz devem ser levados em conta. Para esse pensador, "a educação pós-moderna do professor consiste em tirar o máximo das imprevisíveis complicações de sala de aula” (KINCHELOE, 1997, p. 44).

\footnotetext{
${ }^{13}$ Emprestamos a expressão no sentido em que é usada por Kiziltan, Bain e Cañizares (1993, p. 225) para se referir à pós-modernidade como a imagem de um labirinto que contrasta com um mundo ideal iluminista.
} 
Com base na exposição acima, entendemos que a educação depara-se com imensos desafios. Por ter seus ideais baseados nos preceitos da modernidade, conforme apontam Usher e Edwards (1994, p. 24), qual o seu papel diante de uma condição pós-moderna, na qual as verdades não são fixas e universais? Partindo da premissa de que todo discurso é construído por outros discursos, acreditamos ser possível identificar no discurso educacional, materializações lingüísticas e discursivas que, apesar de apontar para a problematização e descentralização das verdades, acabam por revelar pressupostos modernistas. Postulamos haver no discurso educacional um conflito de objetivos: por um lado, o papel arraigado da educação como transmissora de "grandes narrativas", nas palavras de Lyotard (1986), mas, por outro lado, sua "responsabilidade" pós-moderna de desmitificar verdades. Nesse sentido, a análise empreendida por Mascia (2002) sobre o funcionamento do discurso políticoeducacional é bastante exemplar. A partir de uma perspectiva discursivo-desconstrutivista, a autora investiga diversos documentos curriculares ${ }^{14}$ envolvendo o ensino de língua estrangeira, além de depoimentos escritos e orais de professores da rede pública, professores universitários, monitores de delegacia de ensino, entre outros.

A autora parte da premissa de que as reformas curriculares estão pautadas num "ideário de progresso" (p. 18), por isso, a fim de traçar as origens desse ideário, resgata os pressupostos filosóficos do positivismo e suas influências no Brasil. Após esse traçado histórico, mostra como se dá a inserção do ideário de progresso na educação na era da modernidade e, a partir daí, com base nos conceitos da pós-modernidade, passa a investigar o funcionamento discursivo das reformas educacionais e a problematizar seus fundamentos. Ao analisar as condições de produção dos documentos, por exemplo, Mascia (2002, p. 87) diz existir no imaginário dos sujeitos envolvidos na sua elaboração "um processo de integração livre e igualitária entre os membros interessados". Isso pode parecer característico de um momento pós-moderno, no qual se busca valorizar a diversidade. No entanto, a análise da pesquisadora mostra materializações lingüísticas que sugerem a permanência hierarquizada do poder entre as instâncias responsáveis pelos documentos (governo, pesquisadores, professores). Ou seja, em última análise, mantém-se a mesma estrutura padronizada das relações de poder.

\footnotetext{
${ }^{14}$ Os documentos pesquisados são: Proposta Curricular de Língua Estrangeira Moderna - Inglês $\left(1^{\circ}\right.$ grau, 1988 e $2^{\circ}$ grau, 1989), Subsídios para a implementação da Proposta Curricular de língua inglesa (1980), quatro volumes do material subsidiário A Prática Pedagógica (dois volumes de $1^{\circ}$ grau, 1993 e 1994 , e dois de $2^{\circ}$ grau, 1993 e 1994) e os Parâmetros Curriculares Nacionais ( $3^{\circ}$ e $4^{\circ}$ ciclos do Ensino Fundamental - Língua Estrangeira, versão preliminar de outubro de 1997) (MASCIA, 2002, p. 22).
} 
Trazemos, finalmente, reflexões sobre a pós-modernidade elaboradas por Bauman (2000/2001), as quais adotaremos em nossa análise, por acreditarmos que são elas que, fundamentalmente, nos possibilitam fazer maiores articulações com a educação e, por conseguinte, com a formação de professores de inglês - nosso foco principal. Esse sociólogo emprega a designação "modernidade líquida" para indicar a fluidez do estágio presente da atualidade. Inicia sua teoria buscando o significado da palavra "fluidez" em uma enciclopédia que apresenta como sendo "a qualidade de líquidos e gases". A definição prossegue, detalhando que a característica que os distingue dos sólidos é o fato de que "não podem suportar uma força tangencial ou deformante quando imóveis" e assim "sofrem uma constante mudança de forma quando submetidos a tal tensão" (2001, p. 7). Dessa forma, comenta que é característica dos líquidos não manterem sempre a mesma forma, estando sempre prontos e propensos para a mudança. Ações como: fluir, escorrer, esvair-se, respingar, transbordar, vazar, inundar, borrifar, pingar, filtrar e destilar são características dessa fluidez da modernidade líquida. Enfim, fluidez ou liquidez são as metáforas utilizadas para captar a natureza desse momento.

Aproximando-se de algumas concepções referidas, anteriormente, o autor de Modernidade líquida apresenta duas características marcantes dessa nova forma de modernidade que afetou diversos aspectos de nossas vidas. A primeira característica dessa transição da modernidade "pesada" e "sólida" para aquilo que ele classificou como modernidade líquida é o colapso gradual e rápido da ilusão moderna; ou seja, a esperança da totalidade deixa de existir, bem como a noção de que há um fim do caminho a atingir, uma perfeição, o domínio sobre o futuro. Vale lembrar que, em outro trabalho, Bauman (1991/1999a) discute que a modernidade foi um período marcado pela promessa da ordem entre o mundo, o habitat humano e do eu humano, no qual se acreditava na clareza e na transparência na vida humana. Um dos grandes embates da modernidade, então, para o sociólogo, é a tentativa de sufocar a ambivalência presente no mundo, especialmente na linguagem. Desse modo, vê que a pós-modernidade é o momento do aprendizado, da tentativa de se aprender a viver com a ambivalência, a ambigüidade, a bifurcação de sentidos.

A segunda característica apresentada é a desregulamentação e a privatização das tarefas e deveres modernizantes. O que costumava ser visto como tarefa coletiva ou atribuição do Estado, do Governo, de uma instituição passou a ser atribuição de cada indivíduo. Para o autor, na pós-modernidade, "nós, humanos, nos encontramos por nossa própria conta" (2001, 
p. 37). Ele explica que entende por individualização o fato de "transformar a 'identidade' humana de um 'dado' em uma 'tarefa' e encarregar os atores da responsabilidade de realizar essa tarefa e das conseqüências (assim como dos efeitos colaterais) de sua realização" (2001, p. 40). O despertar e a compreensão da responsabilidade individual é uma das principais implicações de tal mudança, conforme advoga. Esses conceitos nos provocam a pensar sobre suas implicações e decorrências no campo educacional, notadamente na formação de professores. Desse modo, buscamos, no presente trabalho, refletir sobre essa delegação de deveres para o indivíduo no contexto educacional - aspecto que não é explorado detalhadamente na obra desse pensador. ${ }^{15}$

Acreditamos ter explicitado, até o momento, algumas reflexões, das quais partimos para formular nossas questões de pesquisa e, finalmente, a tese do trabalho. Antes, porém, haja vista a relevância da noção de contingência para os propósitos deste estudo, cabe-nos fazer alguns esclarecimentos. Logo, essa é a proposta da seção seguinte.

\subsection{Do sentido da contingência à contingência da formação}

Como para a $\mathrm{AD}$, o funcionamento das palavras na história é importante, ou, citando Orlandi (2002, p. 32) “elas [palavras] significam pela história e pela língua”, coligimos algumas definições para os verbetes contingência/contingente. Porém, ressaltamos que não tomamos os sentidos como fixos, estáveis, pois além da impossibilidade de a língua poder expressar um todo, segundo Milner (1978/1987), sabemos da possibilidade de um sentido tornar-se outro, conforme nos diz Pêcheux (1983/2002). Todavia, vale considerar, inicialmente, a acepção dessas palavras em alguns dicionários. De acordo com Houaiss (2001), "contingência" designa "a possibilidade de que alguma coisa aconteça ou não" ou ainda um "fato imprevisível ou fortuito que escapa ao controle; eventualidade". Para o autor, na filosofia, o termo é empregado para designar o "caráter do que ocorre de maneira eventual, circunstancial, sem necessidade, pois poderia ter acontecido de maneira diferente ou simplesmente não ter se efetuado". Para o termo "contingente", o dicionarista nos diz que se trata de algo que "pode ocorrer ou não ocorrer, incerto, que ocorre por acaso ou por acidente, acidental, casual, fortuito, aleatório”. Cita também definição na escolástica que, segundo ele, refere-se a "qualquer ocorrência fortuita e casual quando considerada isoladamente, mas

15 Os conceitos explorados por Bauman, em Modernidade líquida são: Emancipação, Individualidade, Tempo/Espaço, Trabalho e Comunidade. 
necessária e inevitável ao ser relacionada às causas que lhe deram origem”. No spinozismo, "diz-se de circunstância aparentemente eventual, em decorrência de uma limitação do conhecimento humano na compreensão de sua origem causal". Para concluir, na filosofia contemporânea, "diz-se de evento natural ou humano que se caracteriza por sua absoluta indeterminação e imprevisibilidade".

Trazemos também contribuições da filosofia para os termos, a partir de três fontes. Para Lalande (1999, p. 203), "a palavra contingência opõe-se em todos os sentidos a necessidade". O autor de Vocabulário técnico e crítico da filosofia apresenta também a definição do termo em um sentido geral e em um sentido absoluto. No geral, contingente é "tudo aquilo que é concebido como podendo ser ou não, sob qualquer aspecto e sob qualquer reserva que seja” (p. 203). No absoluto, "um futuro é contingente se, sendo todas as coisas aquilo que são, esse futuro se pode produzir ou não; em outras palavras, se a sua realização ou a sua não-realização são igualmente ‘compossíveis' neste presente estado de coisas” (p. 204, grifo do autor).

Abbagnano (2000, p. 200-201) afirma que a definição do termo contingente é "ambígua e pouco coerente". Segundo ele, a terminologia filosófica latina atribuía o mesmo significado para possibile e contingens. Na tradição escolástica (sobretudo por influência da filosofia árabe), o termo passou a designar aquilo que "embora sendo possível em si [no conceito], pode ser necessário em relação a outra coisa, ou seja, àquilo que o faz ser”. E, na doutrina de Spinoza "uma coisa só pode ser considerada por um defeito de nosso conhecimento, já que na realidade, nada há de contingente e tudo é determinado pela natureza divina para ser e para atuar de certo modo". Para o dicionarista, na filosofia contemporânea, (notadamente a francesa), “o termo contingente passou a ser sinônimo de 'não-determinado', [...] de livre e imprevisível; designa especialmente o que de livre, nesse sentido, se encontra ou age no mundo natural". Finalmente, a contribuição de Ferrater Mora (2000, p. 567) esclarece que as definições medievais do termo contingente resumem-se na tese de Santo Tomás, na qual "o contingente é aquilo que pode ser e pode não ser". O autor afirma também que, na visão de Aristóteles, o contingente contrapõe-se ao necessário.

A partir dessa breve exposição, apreciemos como três pensadores, de áreas distintas, apropriaram-se desse conceito em suas reflexões. Inspiramo-nos, inicialmente, nas formulações do crítico pós-colonial, Homi K. Bhabha (1994/2007, p. 259), sobre o conceito 
de sujeito, identidade e agência. Para ele, o contingente é "contigüidade, metonímia, tocar as fronteiras espaciais pela tangente, e, ao mesmo tempo, o contingente é a temporalidade do indeterminado e do indecidível”. Aplicando essa definição para os seus propósitos, surge daí a noção de sujeito/agente visto como parcial, não soberano, suplementar, instável, móvel e que, por isso, rejeita o conceito de identidade fixa e estável. A posição do sujeito é sempre contingente, isto é, altera-se à medida que se altera seu lócus de enunciação (local de onde fala). A contingência do sujeito não inviabiliza a possibilidade de sua agência política, no entanto, a visão de agência soberana, em que as grandes narrativas fizeram acreditar, tornamse irrealizáveis (informação verbal) ${ }^{16}$. Pelo modo como o conceito de contingência é mobilizado por esse crítico indo-britânico, fomos expostos a uma gama de sentidos possíveis que sintetizamos: construções/constituições duplas, disjunções, indeterminações, indefinições, deslocamentos. Enfim, essas são algumas noções inicias que nos projetaram para a elaboração da nossa tese.

Examinemos, a seguir, contribuição do campo da filosofia sobre esse tema, elaborada por Rorty (1989/1994). Nesse trabalho, o autor explora a contingência da linguagem, a contingência da individualidade e a contingência de uma comunidade liberal com o objetivo de sugerir a possibilidade de uma "utopia liberal". ${ }^{17}$ A contingência da linguagem refere-se à impossibilidade de "sair dos vários vocábulos que temos usado e de encontrar um metavocabulário que, de algum modo, dê conta de todos os vocabulários possíveis, de todas as maneiras possíveis de julgar e de sentir" (1994, p. 19). Ou seja, a linguagem é limitante fator que propicia (re)descrições constantes e intermináveis da realidade. Para esse filósofo, não há possibilidade de construir uma realidade fora da linguagem. Isso corresponde a dizer que toda realidade é sempre uma descrição; não existe uma realidade pronta "lá fora" à espera de ser desvelada. Esse filósofo vê na linguagem um instrumento que o homem possui para (re)escrever/(re)descrever a realidade e o mundo em que vive, conforme as suas necessidades e contingências. Sua tese é de que "só as frases podem ser verdadeiras e que os seres humanos fazem verdades ao fazerem linguagens nas quais formulam frases" (1994, p. 31).

\footnotetext{
${ }^{16}$ Contribuições provenientes da palestra Homi K. Bhabha: hibridismo e tradução cultural na linguagem, proferida pelo professor Dr. Lynn Mario T. Menezes de Souza, em setembro de 2004, na FFLCH/USP.

${ }^{17}$ Conforme Rorty (1994, p. 17), sua obra desenha a figura de um "ironista liberal", isto é, alguém que encara a contingência das suas crenças e desejos ("ironista") e acredita que a crueldade é a pior coisa que se pode praticar ("liberal"). Daí decorre o papel da solidariedade humana como única maneira de se manter unidade frente à transitoriedade dos seres humanos. De acordo com análise de Azevedo (2007, p. 16), a intenção de Rorty é propor uma nova auto-imagem para a filosofia, pautada na necessidade de procurar um futuro mais satisfatório que o presente, auxiliando os indivíduos a encontrar novas formas de adaptação em um mundo em constante transformação.
} 
Quanto à contingência da individualidade, Rorty (1994) defende que Freud, Nietzsche e o crítico literário norte-americano, Harold Bloom, revelam a contingência da nossa consciência. Segundo sua análise, foi Nietzsche o primeiro a sugerir que a idéia de "conhecimento da verdade" deveria ser abandonada. Argumenta que a definição de verdade como "exército móvel de metáforas"18, proposta por esse filósofo alemão, insinuava o abandono da noção de "representação da realidade" por meio da linguagem, assim como da intenção de se encontrar um contexto único para todas as vidas humanas. Dando continuidade à sua análise, Rorty sugere que a contribuição do fundador da psicanálise foi a de "desdivinizar o eu ao ir encontrar a origem da consciência nas contingências da nossa formação" (1994, p. 55). Essa sugestão está baseada no rompimento das distinções entre superior/inferior, essencial/acidental e central/periférico que Freud propõe, revelando um "eu" que se constitui a partir de contingências e não de um conjunto de faculdades, sobre as quais se pode exercer controle. Concluindo suas reflexões sobre esse segundo aspecto (individualidade), o autor de Contingência, ironia e solidariedade argumenta que, assim como Freud desdivinizou a consciência e Nietzsche, a verdade, Bloom o fez em direção ao poema e, por conseguinte, ao poeta. Para esse crítico literário, um poema nunca contém um significado em si mesmo, sua unidade está na interação com o leitor e no movimento que ele fará para buscar conexões com outros poemas. Com esse movimento de transferência ou projeção de significados para elementos "externos" ao poema em si, Rorty sinaliza a impermanência de uma interpretação única, individual e soberana, isto é, a interpretação compreende novas interpretações. $O$ que notamos desse aspecto da contingência da individualidade é que a noção de verdade, consciência e interpretação fechadas, únicas e absolutas foram desestabilizadas, conforme leitura de Rorty. Há de se considerar o inesperado, o imprevisível, o novo (contingente) que virá complementar, desviar ou transformar essas noções.

Finalizando esta breve exposição do pensamento rortyano, a contingência de uma comunidade liberal remete à noção de contingência exposta nos âmbitos anteriores (linguagem e individualidade). A concepção política de Rorty sobre a construção de uma "sociedade liberal” implica a aquiescência dos cidadãos de que tanto sua linguagem como sua consciência são contingentes, portanto, o que importa são as mudanças que a própria

\footnotetext{
${ }^{18}$ Em momento anterior no estudo, Rorty (1994, p. 39) reflete sobre a história da linguagem, asseverando que antigas metáforas morrem ao tornarem-se literais, e que, desse modo, passam a servir de base para a formação de novas metáforas. Para ele, a linguagem (da ciência e da cultura) apresentada como tal, não passa do resultado de puras contingências. Dito de outro modo, a linguagem é constitutivamente efêmera.
} 
redescrição, de acordo com novas contingências, torna possível. Essa redescrição depende, contudo, da consciência de que as necessidades se alteram, justificando a necessidade de reescrevê-las (buscar novas metáforas), daí a idéia de contingência para fazer referência à possibilidade de isso ocorrer. Em outras palavras, uma atitude contingente (que poderá ocorrer) que incorpora ou possibilita a incorporação de novas metáforas (sentidos) por meio de novas descrições, sem o objetivo de chegar a uma verdade única que descreva a natureza humana e do mundo, poderá levar a uma "nova" sociedade (utópica), na qual valores morais, éticos, culturais abram espaço para o diferente (nova metáfora). ${ }^{19}$

Nossas conclusões sobre a questão da contingência trazida por esse filósofo norteamericano apontam para a construção de algumas "metáforas" que buscaremos sintetizar. Sobre a linguagem, depreende-se que sua contingência refere-se à sua natureza limitante, passageira e, indefinidamente, dependente de um outro significante. No que tange à individualidade, a partir das perspectivas da filosofia, a contingência é o oposto da unicidade, da totalidade, da fidedignidade. Do ponto de vista psicanalítico, a ausência de domínio, da integralidade, da soberania do "eu" são as "metáforas" que apreendemos. Da perspectiva da literatura, a leitura de Rorty nos propicia associar a contingência com noções de incompletude, parcialidade, encadeamentos sucessivos. Para finalizar, o pensamento político rortyano (construção de uma comunidade liberal) nos leva a compreender que a transitoriedade, a finitude, a impermanência, o acaso são noções vinculadas com a contingência, nessa dimensão abordada.

Para melhor discutir a noção de contingência que mobilizamos em nossa pesquisa, devolvemos a palavra ao sociólogo polonês, Zygmunt Bauman. Conforme já acenamos na seção anterior, na sua visão, um dos grandes enfrentamentos da modernidade residia na tentativa de sufocar a ambivalência presente no mundo, sobretudo na linguagem. Logo no início do seu ensaio, o autor apresenta uma definição para o termo "ambivalência" como sendo a

[...] possibilidade de conferir a um objeto ou evento mais de uma categoria, é uma desordem específica da linguagem, uma falha da função nomeadora (segregadora) que a linguagem deve desempenhar. [...] A ambivalência é, portanto, o alter ego da linguagem e sua companheira permanente - com efeito, sua condição normal. (BAUMAN, 1999a, p. 9).

\footnotetext{
${ }^{19}$ Cabe salientar que, do ponto de vista da $\mathrm{AD}$, todo sentido é sempre metafórico.
} 
Isto posto, concluímos, então que a ambivalência é constitutiva da linguagem e, conseqüentemente, do sujeito, do sentido e do discurso. O desvio dos sentidos, a inconstância das subjetividades e a possibilidade de reinterpretações colocam em cena um outro que se mantinha latente. Com efeito, para Bauman (1999a), o colapso da noção da ordem (do mundo, do habitat humano e do eu humano, bem como da conexão entre os três) que a modernidade se imputava fez despontar seu outro: o indeterminado, o imprevisível. De maneira encadeada, o outro do Estado (poder regulador) é a ambigüidade ("terra de ninguém ou contestada"), o outro da soberania é a violação, a desobediência, por fim, “o outro do intelecto moderno é a polissemia, a dissonância cognitiva, as definições polivalentes, a contingência, os significados superpostos" (1999a, p. 16). É nesse ponto que surge, então, a contingência, em oposição à determinação, isto é, seu outro. É sobre essa questão que nosso trabalho pretende avançar. Com a derrocada dos propósitos ordenadores da modernidade (fixar sentidos, padronizar individualidades, definir poderes, estabelecer regularidades etc.), a contingência se impõe como a manifestação da indeterminação, da incerteza, da dúvida, do acaso. Nessa linha de raciocínio, é legítimo afirmar que a contingência é o legado da modernidade, a herança de uma promessa iluminista não cumprida, o fruto da ambivalência que esteve "sempre lá". Partindo dessa premissa, podemos acrescentar também que a pós-modernidade nos posiciona de maneira provisória, cambiante, instável diante do mundo, da forma como vemos o mundo e das relações (sociais, culturais, políticas etc.) que nele estabelecemos. Sendo assim, acreditamos que as transformações dessa nova forma de modernidade colocam em cena uma noção de contingência que, apesar de apagada, negada ou sufocada com mais veemência, a partir de uma perspectiva moderna, no contexto pós-moderno, está sempre permeando, de modo mais evidente, a linguagem, os sentidos, os conceitos, as relações humanas, enfim.

Dessa forma, se, conforme defende Rorty, a contingência constitui o ser, marcando sua existência com incertezas e indefinições; se a linguagem jamais se completa, o significado está sempre atrelado a novas descrições; e, se a sua comunidade liberal está inscrita no acaso, na possibilidade de que cidadãos se apercebam como criaturas entrelaçadas pelas contingências (dúvidas, ambigüidades, incertezas) que os constituem, conforme afirma Bauman (1999a, p. 261), ela não pode mais ser erradicada, apenas desintoxicada, pois a pósmodernidade é a idade da contingência. Considerando que, segundo esse mesmo sociólogo, o mundo contingente é o mundo do acaso, da indefinibilidade, da incoerência, da incongruência, da incompatibilidade, da ambigüidade, da ambivalência, da incapacidade de decidir, da vida sem garantias, e que, portanto, não podemos negligenciar a contingência, 
sendo sua aceitação a única forma de "emancipação", cabe interrogar como a contingência tem nos constituído, assumindo a premissa de que, por meio de novas descrições, seus sentidos deslizam e se expandem para novas definições. Dito de outro modo, a contingência deve ser considerada e não sufocada, pois ela também atribui sentidos e valores ao que se é, se busca, se pensa, de modo geral, e, se ensina, se aprende e no modo como se ensina e se aprende, no plano educacional.

Essas considerações, acima expostas, nos autorizam a investigar os efeitos de sentido que a contingência constitutiva assume no campo educacional, notadamente, na formação de professores de inglês - foco principal deste trabalho. Baseando-nos, então, nas formulações de Bauman (1997/1998, 1999a, 2001, 2004/2005) sobre a pós-modernidade e, por meio dela, a noção de contingência, nossa tese é que diante dessa mudança de paradigma e desse painel da pós-modernidade (ambivalência, fluidez, inconstância, incerteza etc.), que revela um modus vivendi contingente, podemos estar diante da institucionalização de uma formação contingente ou da legitimação, por meio da atribuição de um "estatuto" contingente, de uma formação precária, temporária, ad hoc. Esse "estatuto" de formação contingente designa um professor que se forma na condição just in case, eventual ou tangencial. A partir dessa perspectiva, sua "formação" pode ser, portanto, postergada para um futuro contingente e sob a responsabilidade de um outro ${ }^{20}$. Ou seja, a formação desse profissional está vinculada a um elemento outro que está por vir (outro curso, especialização, pós-graduação etc.). Assim sendo, objetivamos apontar, no decorrer da análise, o modo como vemos a irrupção da ambivalência nos discursos analisados e, por meio dela, tentaremos argumentar que esses momentos, essencialmente contingentes, revelam um deslizar constante de sentidos, intenções e ações, os quais acabam por implicar uma "formação" que não se completa. É nesse sentido que mobilizamos a noção de contingência.

Conforme argumentamos, no início desta seção, não ignoramos que é impossível à língua expressar um todo (MILNER, 1987), que a ambivalência é a "condição normal" da linguagem (BAUMAN, 1999a) e que um sentido pode tornar-se outro (PÊCHEUX, 2002), sendo, desse modo, contingente (RORTY, 1994). Portanto, a questão que colocamos aqui não é investigar algo que assumimos como condição básica, inerente da linguagem. Nosso

\footnotetext{
${ }^{20}$ Inspiramo-nos nas concepções do princípio dialógico de Bakhtin (1979/2003, p. 21-90), que preconiza a existência do diálogo entre interlocutores e entre discursos. Nesse sentido bakhtiniano, o outro é imprescindível, sendo, portanto, impossível pensar no homem sem considerar as relações que o ligam ao outro, ou seja, o ser humano é definido por meio da alteridade.
} 
interesse é refletir sobre os efeitos de sentido produzidos nos discursos político-educacional e didático-pedagógico que constituem o corpus que aqui apresentamos com o objetivo de entender como seu funcionamento discursivo ${ }^{21}$ pode produzir representações sobre a formação de professores de inglês. Admitindo que a contingência é inescapável, a questão é, então, buscar identificar quais efeitos de sentido ela pode agregar à concepção de formação de professores de inglês. Quando sugerimos a questão da institucionalização de uma formação contingente, estamos considerando o modo de funcionamento de algumas práticas e relações sociais que, ao se repetirem, passam a ser reconhecidas por quem as faz e por quem as observa. Conforme nos diz Guilhon Albuquerque (1980), com esse efeito de reconhecimento, certas práticas e relações tornam-se naturalizadas ou legitimadas, sendo, portanto, institucionalizadas. Por isso a importância do conceito orlandiano de funcionamento discursivo pois, como bem traduziu Passos (2006, p. 54), "há formas de discurso que se cristalizam, tornam-se modelos e se institucionalizam.” Ou seja, há dizeres que se repetem e por meio dessa repetição se legitimam, tornando-se "verdades" incontestáveis. Diante disso, e, assumindo a contingência como constitutiva da linguagem, dos sentidos, das práticas e das relações sociais, pode ocorrer a legitimação de um tipo de formação que se "completa" em um futuro contingente, casual, fortuito, isto é, uma formação "legitimadamente" postergada.

Ordenaremos nosso percurso investigativo, focalizando quatro diferentes dimensões de ocorrências de ambivalência. Iniciaremos essa exposição, a partir do Capítulo 3, no qual argumentaremos que os deslizamentos de sentidos das propostas curriculares, apontados em estudos estrangeiros, são frutos de uma ambivalência designada, por nós, como constitutiva. Com isso, intencionamos promover articulações com a análise das Diretrizes Curriculares, no sentido de indicar a ambivalência, também, presente nesse discurso político-educacional. Nesse âmbito, inicialmente, traremos à baila os momentos de ambivalência presentes nas condições de produção dos documentos analisados (entrevistas com seus elaboradores), segundo nicho investigado, para, em seguida, apontarmos a ambivalência nos próprios documentos (terceiro foco de ambivalência). Finalmente, mostraremos, no discurso didáticopedagógico dos professores e alunos em dois cursos de formação de professores de inglês (quarta dimensão), como entendemos que os momentos analisados podem se constituir de

${ }^{21}$ Conceito elaborado por Orlandi (2006, p. 125) que designa a estrutura de um determinado discurso, cujas finalidades são, previamente, conhecidas assim como o falante e seu interlocutor. É pelo e no funcionamento discursivo que são representados os interlocutores e as relações que mantêm com a formação ideológica. 
forma a apontar para a contingência dessa formação. Neste ponto, é fundamental apresentarmos nossas questões de pesquisa.

Nossas perguntas abordam o corpus constituído pelos documentos (Diretrizes Curriculares), entrevistas com dois membros dos comitês elaboradores (condições de produção) e entrevistas com professores e alunos de cursos de formação de professores de língua inglesa. Desse modo, quanto aos documentos (incluindo as entrevistas com elaboradores), visamos, inicialmente, responder às seguintes perguntas:

1) Quais aspectos são valorizados no processo de formação de professores - em especial, do professor do curso de letras nas Diretrizes Curriculares? ${ }^{22}$

2) Qual a noção sobre formação de professores que esses documentos imprimem, fundamentalmente, sobre o professor de línguas?

3) Quais as características desse futuro professor de letras?

Sendo a ambivalência condição sine qua non dos indivíduos, da sociedade, de suas histórias, que a pós-modernidade ajudou a descortinar, pretendemos também em nosso percurso investigativo, transitar da parte documental para as entrevistas com professores e alunos de dois cursos de formação de professores de língua inglesa, buscando encontrar respostas para as seguintes questões:

4) Como a ambivalência irrompe no discurso político-educacional das Diretrizes Curriculares, nas suas condições de produção e no discurso didático-pedagógico dos professores e alunos das instituições pesquisadas?

5) Há materializações lingüísticas no discurso de professores e alunos que apontam para uma noção de formação contingente?

\footnotetext{
${ }^{22}$ Esclarecemos que as Diretrizes Curriculares para os cursos de Letras não tratam especificamente da formação de professores de inglês.
} 
Baseando-nos em reflexão de Bauman (2005, p. 34), que sugere como um dos efeitos da globalização a falta de interesse do Estado "de manter uma união sólida e inabalável com a nação", fazendo com que direitos sociais tornem-se deveres individuais, ${ }^{23}$ cabe-nos interrogar:

6) Que marcas se apresentam como sugestivas de responsabilização individual na formação do professor de inglês, nas duas instituições pesquisadas?

Ainda a respeito de outra interpretação desse pensador (2005, p. 98), na qual sugere que "todos estamos dentro e no mercado, ao mesmo tempo clientes e mercadorias", indagamos também:

7) Há sinais no discurso dos professores e alunos, nas duas instituições pesquisadas, capazes de indicar esse tipo de relação apontada por Bauman?

Dando continuidade a nossa exposição e buscando contextualizar as condições de produção da pesquisa, formando uma plataforma sobre a qual construiremos nosso trabalho, no Capítulo 2, mostraremos um painel de estudos sobre a formação de professores/de professores de língua inglesa a fimm de situar nossa inserção nesse panorama. No Capítulo 3, em virtude da noção de currículo ser também fundamental neste trabalho, descreveremos algumas discussões nesse campo, à guisa de um preâmbulo, com o objetivo de promover articulações com a análise documental que dá início à Parte II deste estudo.

23 Sobre esse tema, lembramos também outro trabalho de Bauman (1998/1999b), Globalização: as conseqüencias humanas. 


\section{CAPÍTULO 2}

\section{FORMAÇÃO DE PROFESSORES}

Há uma idade em que se ensina o que se sabe; mas surge em seguida uma outra em que se ensina o que se não sabe: a isso se chama procurar.

Roland Barthes. Lição.

Na primeira seção deste capítulo, apresentamos trabalhos referentes à formação de professores, de forma mais geral, cujas questões estão relacionadas à profissionalização, saberes docentes, cotidiano escolar, entre outras, com o objetivo de mostrar um recorte de algumas discussões ocorridas nessa área e como as conclusões apresentadas suscitam, reforçam ou divergem de nossas preocupações. Na segunda seção, debruçamo-nos sobre pesquisas que abordam, mais especificamente, a formação de professores de inglês.

\subsection{Esboçando reflexões sobre a formação de professores}

Iniciamos com alguns traçados históricos apontados por Santos (2002). Para ela, a década de 1960 foi marcada por uma investigação da relação entre processo de ensino e os produtos de aprendizagem. Durante esse período, o objetivo era buscar as melhores formas de ensinar e como preparar os professores para utilizá-las. Na década seguinte, a questão passou a ser o papel político do professor. Os estudos pedagógicos de natureza crítica surgidos nessa época mostraram as relações entre Estado, classe social, ideologia e educação. Segundo Santos, há uma tendência nas décadas mais recentes, no campo da formação docente, de buscar saber como o professor é formado nas e pelas instituições escolares. Essa tendência, segundo a autora, origina-se com as mudanças econômicas, políticas, sociais e culturais ocorridas na sociedade, fazendo com que as investigações educacionais tomem um novo rumo. Busca-se compreender como a história de vida do professor e sua trajetória profissional se cruzam, modelando seus comportamentos, suas perspectivas profissionais, sua visão e suas concepções sobre a educação, o processo de ensino, a organização do trabalho escolar, as políticas que orientam direta ou indiretamente sua prática pedagógica. Perseguindo essa mudança de paradigma, questões como identidade, carreira, processos de formação, constituição de saberes docentes, políticas educacionais são temas recorrentes em pesquisas recentes, conclui a pesquisadora. Assim, nossa proposta de estudo sobre as Diretrizes pode 
significar a abertura de um leque de opções que pode estar inserida nessa tendência, conforme também mencionaram os membros das comissões que participaram da elaboração desses documentos, como veremos adiante. Pensamos que, sobretudo, investigar e problematizar a formação do professor de inglês pode ajudar a detectar inquietações que ocorrem no interior dos cursos e a pensar sobre nossa posição diante delas.

Sintetizando algumas conclusões de Santos (2002), há pontos que deveriam ser considerados nas pesquisas voltadas para a formação docente, que nos interessam para o propósito desta pesquisa. Quanto à organização curricular, por exemplo, além de se tentar buscar maneiras de superar a dicotomia entre teoria e prática, deveria também haver um maior questionamento sobre a separação existente entre ensino e pesquisa, no interior das universidades e das instituições voltadas para a formação docente. Acima de tudo, deveria se buscar a superação da estrutura disciplinar que prevalece nos currículos desses cursos, considerando-se, ainda, a importância dos saberes práticos na formação profissional do professorado.

Discussão sobre as Diretrizes Curriculares para a formação de professores foi elaborada pelo trabalho de Laranjeira (2003) que, por ter coordenado ações de formação de professores junto à Secretaria de Educação Superior do Ministério da Educação, esteve presente no grupo que participou da elaboração desses documentos. Como defensora dessas propostas, critica a distância existente entre os cursos de Educação Básica e as escolas de formação de professores, afirmando que tais cursos desconhecem o conteúdo desses documentos. Com isso, vê que a Educação Básica tem sua qualidade prejudicada por desconhecer as finalidades específicas de cada uma de suas fases, figurando apenas como prérequisito da fase seguinte. A pesquisadora entende que a fragmentação dessas fases acaba por tratar o aluno "como alguém que ainda vai ser alguém, ignorando suas tarefas de desenvolvimento próprias de cada uma das etapas" (p. 45). Para tanto, apresenta dados estatísticos referentes aos índices de reprovação que marcam os primeiros anos de cada etapa inicial da Educação Básica; por exemplo, o ano inicial do Ensino Fundamental, revelando sua fragmentação em relação à Educação Infantil; ou ainda, o primeiro dos anos finais do Ensino Fundamental ( $5^{\mathrm{a}}$ série), que revela a ruptura com os primeiros anos dessa mesma etapa. 
Nesse trabalho, além de apresentar sua defesa pelas Diretrizes Curriculares Nacionais para a Formação de Professores da Educação Básica (de ora em diante DCF), apresenta um painel histórico sobre as discussões que antecederam a elaboração desse documento e analisa o programa de um curso de formação de professores, tendo como parâmetro as orientações sugeridas nesses documentos. Acredita também que as DCF são um grande avanço na área de formação de professores por tratarem da questão da profissionalização do professor e questionarem a prevalência do bacharelado em relação à licenciatura, nas instituições de ensino superior. Prossegue, argumentando que existe um preconceito nas universidades, de modo geral, de que apenas os cursos e profissionais que formam professores devem ser tratados como sendo "da área da educação" - atitude condenável, segundo ela. Concordamos com sua crítica, pois também entendemos que, se o professor está envolvido na questão da aprendizagem dos seus alunos, independentemente de sua área de interesse, não há dúvida acerca de sua inserção na área de educação.

A questão central do seu trabalho, na verdade, reside na discussão sobre o desenvolvimento de competências que são preconizadas pelas DCF. Para tanto, vê a necessidade de submeter essas competências a um processo de ressignificação, tendo como ponto de partida o perfil do profissional que deve ser formado. Desse modo, para construir um projeto de curso de formação de professores, após definição desse perfil, as etapas que se seguem devem ser: "o estabelecimento das competências, a seleção e o tratamento dos conteúdos, os princípios metodológicos e as funções da avaliação" (p. 74). Para Laranjeira, estabelecer competências, na perspectiva das DCF é pensar nas funções que estão implicadas nas dimensões do perfil do profissional a ser formado, definindo os conhecimentos que são necessários para exercer sua atividade profissional. Para a autora, pensar em desenvolvimento de competências ao invés de acúmulo de conhecimentos propicia o rompimento da dicotomia teoria/prática presente nos cursos de formação de professores, por partir de uma lógica que enfatiza a questão do "fazer". Algumas de suas considerações tratam ainda da questão do trabalho coletivo na escola como dimensão da atuação profissional do professor em formação. Esse tema é apontado pela autora da tese como um compromisso da formação, pois é preciso “desencadear um processo de revisão de valores capaz de higienizar as atitudes contaminadas pela cultura da individualidade que marca a convivência" (p. 86).

Para o que nos interessa neste trabalho (a formação de professores de inglês), algumas dessas conclusões apontadas, tais como a questão da profissionalização do professor, o 
preconceito existente nas universidades, de modo geral, sobre a área da educação, a dicotomia teoria/prática presente nos cursos de formação de professores e a cultura da individualidade, são temas que também serão explorados no decorrer deste estudo.

Com relação à constituição de saberes docentes, Therrien (2002) defende que o docente deve ser formado para ser um permanente pesquisador de sua prática. Para tanto, ele destaca quatro categorias que considera centrais na formação docente: seu trabalho, seu saber, sua cultura e sua racionalidade. O trabalho é caracterizado como a transposição de saberes com outros sujeitos. Seu saber diz respeito a uma apreensão simbólica da realidade, incluindo a cultura em todas as suas dimensões, subdividindo-se ainda em: saberes disciplinares e curriculares, saber de formação pedagógica, saber da experiência profissional e saberes da cultura e do mundo vivido na prática social. Quanto à cultura, ela diz respeito à pluralidade de saberes ou ao repertório de conhecimentos disponíveis e mobilizados pelo docente para conduzir sua ação pedagógica no contexto da sala de aula, ou seja, é uma "cultura em ação". Finalmente, sobre a questão da racionalidade, ele a apresenta como sendo o produto da reflexão sobre a ação e expressão da relação teoria/prática. Enfim, é uma categoria voltada para a racionalidade prática que move o docente no seu trabalho.

No nosso entendimento, todas essas categorias são necessárias e merecedoras de um olhar cuidadoso e detalhado. No entanto, destacaremos dentre elas, a questão do saber docente, por nos ajudar nos propósitos deste trabalho e por ser nessa, segundo Therrien, que a articulação entre esses saberes (disciplinares, curriculares, pedagógicos etc.) imprime a marca da identidade do docente. Concordamos com sua afirmação de que essa articulação de saberes deve ocorrer durante o processo de formação. No entanto, entendemos que para ocorrer, de fato, essa articulação, é necessária a mobilização de várias instâncias e elementos que fazem parte do contexto educacional. Por exemplo, como facilitar a compreensão dos alunos com relação ao conjunto das disciplinas de um curso de letras e de um curso de formação de professores e, sobretudo, como promover a compreensão da relação das disciplinas entre os dois cursos? É necessário, sobretudo, questionar como esses saberes são constituídos, quais relações políticas, ideológicas, de poder, enfim, estão presentes nesses saberes. Tentaremos, desse modo, por meio das entrevistas realizadas nas duas instituições de ensino, buscar elementos que denotem a compreensão ou a falta dela por parte dos alunos sobre essa articulação de saberes durante o processo de formação, como ocorre a constituição desses saberes e, acima de tudo, que saberes são esses. Quanto à questão da dicotomia teoria/prática, 
as conclusões desse pesquisador nos fazem pensar que expressões como "professor como permanente pesquisador de sua prática" ou ainda "cultura em ação" sugerem não apenas uma valorização da prática, mas acabam funcionando como um mecanismo que auxilia na constituição ou cristalização desse binarismo, sem tentar entender como ele é construído.

Encontramos exemplos de pesquisas sobre a formação de professores, em âmbito nacional, em análise de Cachapuz (2002) sobre o estudo realizado pela Fundação das Universidades Portuguesas, em 2001, de 376 cursos de graduação naquele país. Esse relatório traz como causas do insucesso nos cursos de graduação, além das deficiências trazidas do ensino secundário, a falta de sensibilidade da universidade portuguesa para escolher professores qualificados pedagogicamente, assim como o fato do desempenho pedagógico não ser tão valorizado quanto o desempenho científico desses professores. Resumiremos, a seguir, alguns aspectos apresentados nesse estudo, que poderão refletir temas presentes no nosso corpus. Uma de suas considerações é de que o ensino superior carece de investigação com ênfase na questão didática dos docentes e não no aspecto pedagógico. Ele entende que deveria haver investigações centradas em problemas concretos de ensino sentidos pelos docentes (e discentes), ou seja, o professor pesquisando sobre sua própria forma de ensinar. Ele apresenta como grande dificuldade para essa mudança de atitude o caráter individualista da função docente, em que "cada um é dono do seu território disciplinar". Para promover uma reflexão didática, esse autor português sugere que deve haver uma quebra do isolamento dos docentes para que eles possam avaliar as relações entre o que ensinam e o modo como ensinam. Cachapuz sugere, por exemplo, a estratégia da observação por pares, na qual poderá ocorrer a partilha de reflexões conjuntas na análise de situações concretas do ensino.

Outro exemplo trazido pelo pesquisador português vem da medicina, com a exploração da perspectiva PBL (Problem Based Learning) ou aprendizagem por meio de problemas. Em seu relato, essa perspectiva teve início nos anos 1960 e foi utilizada na medicina, em virtude da dificuldade de conciliar o surgimento de novas questões médicas com os currículos das universidades. Algumas características citadas sobre essa abordagem dizem respeito a uma maior integração dos conteúdos disciplinares, estrutura curricular voltada para temas e não disciplinas, valorização da aprendizagem cooperativa, entre outras. Cachapuz acredita que, dessa maneira, o olhar está mais dirigido aos processos e não somente aos produtos da aprendizagem. O foco, então, não é na resolução do problema em si, mas no 
aprendizado que ocorre durante as questões e dúvidas que vão surgindo por ocasião da análise de cada problema.

A partir de cada estudo apresentado, buscamos aspectos que nos remetem às questões propostas nesta pesquisa. Além disso, temos tentado evidenciar como iremos abordá-las por meio das análises que virão adiante. Nessa pesquisa que acabamos de apresentar, algumas conclusões também tocam em problemas que desejamos questionar. Primeiramente, o comentário sobre a deficiência trazida do ensino secundário. Desejamos observar se esse tipo de questão está também presente no discurso dos professores dos cursos de licenciatura aqui pesquisados e como ela aparece. Outros resultados apresentados que também nos interessam abordam a questão do preparo didático do professor e o caráter individualista da profissão docente, aspectos que também buscaremos observar se emergem de nosso recorte $\operatorname{discursivo}^{24}$.

Guimarães (2004) afirma que a formação de professores é uma preocupação freqüente nas discussões sobre a educação escolar no Brasil, nos últimos vinte anos. Associando-se a esses trabalhos, esse pesquisador traz estudo no qual discute a formação de professores, nos cursos de pedagogia, letras e história, na Universidade Federal de Goiás. Nas suas justificativas, declara haver pouco conhecimento sobre o que ocorre no interior desses cursos de formação, afirmação que compartilhamos com o pesquisador. Os aspectos analisados na pesquisa são: os saberes docentes veiculados pelos cursos, a identidade profissional que esses saberes proporcionam aos alunos e as práticas formativas utilizadas no processo de formação. Um dos resultados dessa pesquisa mostra que o fato de as licenciaturas desses cursos terem sido ministradas nos próprios institutos proporcionou uma melhoria da qualificação nos quadros de docentes e tem proporcionado o surgimento de atitudes mais positivas em relação à formação de professores. Concordamos com Guimarães, quanto à afirmação "todos os cursos, não só as licenciaturas, lidam com as dimensões do pedagógico e do didático, por estarem envolvidos com o fenômeno formação" (2004, p. 81). Para ele, o desenvolvimento dos cursos deve ter como característica distintiva a intencionalidade de formar professores.

Barros (2005) discute a necessidade de considerar questões referentes ao trabalho "real" desenvolvido pelo professor no cotidiano escolar. Em seu texto, esse conceito é

\footnotetext{
${ }^{24}$ Expressão apresentada por Orlandi (1984, p. 14), que indica "um fragmento da situação discursiva".
} 
empregado para designar atividades vivenciadas pelos docentes no cotidiano, fugindo do que é padronizado, prescrito, regulado. Sua inquietação reside no fato de muitos processos de formação docente não incluírem a análise do trabalho "real" do professor, havendo maior valorização de conhecimentos formais e institucionalizados. Apresenta, então, a noção de "currículo real”, conforme definição de Ferraço, que para maior esclarecimento, julgamos necessário transcrever na íntegra:

Currículo real refere-se à diversidade de ações, inter/ações, super/ações e ressignificações, produzidas e compartilhadas nos cotidianos escolares que possibilitam desencadear processos de formação continuada aos sujeitos (educadores e estudantes) que praticam esses cotidianos. Assim, diferente de qualquer documento prescrito, o currículo real diz da diversidade vivida na escola, fala do trabalho real, se mostra como o hipertexto produzido e compartilhado pelas/nas redes de práticas que produzem subjetividades nos cotidianos escolares. ${ }^{25}$

Esse estudo, portanto, busca chamar a atenção dos pesquisadores na área de educação para as maneiras singulares de ensinar, denominado por ela, de "jeitinhos" do trabalho real. Ao mencionar a questão do valor atribuído à educação pelo mercado, argumenta que, atualmente, há uma lógica para convencer os indivíduos no sentido de escolherem escolas, titulações e professores da mesma forma que escolhem produtos disponíveis no mercado de consumo. Embora estejamos de acordo com essa constatação, julgamos que seu estudo falha por se tornar exatamente o objeto de sua própria crítica. Em outros termos, ao enfatizar a importância do que chamou de trabalho real, sua análise acabou adquirindo valor prescritivo por não ter apresentado exemplos do que denominou como "jeitinhos" no cotidiano escolar. Acreditamos que sua perspectiva fornece uma entrada por onde se podem agregar sentidos a uma educação pós-moderna que leve em conta a contingência, a incerteza, a transitoriedade dos conteúdos curriculares. No entanto, sua pesquisa não avança nesse sentido.

Também sobre o tema "cotidiano escolar", Amorim (2005), cujos trabalhos abordam propostas de formação de professores, defende, nesse estudo, a importância de investir nas relações entre cotidiano, formação de professores e currículo como "invenção" de subjetividades. Para ele, é preciso refletir sobre propostas e planos de formação de professores, não deixando de considerar que estão sempre "condicionados às situações conflitantes, díspares, de relações de poder e de uma política mais localizada em princípios de subjetividade do que na racionalidade objetiva" (p. 118). Portanto, nessas propostas, as

\footnotetext{
${ }^{25}$ FERRAÇO, 2002 apud BARROS, 2005, p. 79.
} 
identidades estão sujeitas ao jogo da diferença por estarem intimamente relacionadas com questões históricas e políticas. Explica que não se deve pensar na relação professor/cotidiano por meio de imagens excludentes ou conceitos que se polarizam, tais como: híbrido/puro, permanência/mudança. A diversidade, a heterogeneidade inerente nessa articulação deve ser analisada como fatores que coexistem, afirma. Entendemos que a questão levantada por esse pesquisador é pensar na constituição da identidade do professor como processo interminável de incorporação e transformação. Ele usa ainda exemplo das imagens obtidas em fotografias, explicando que se deve olhar para elas como maneiras de construir as experiências do cotidiano e não como expressão verdadeira. Notamos proximidade dessa comparação com conceito de representação de Hall (1997), mencionado em momento anterior. O ensaio de Amorim defende, portanto, que pensar na identidade do professor nos tempos atuais, é pensar num sujeito que não está limitado a dois pólos, obrigando-se a optar entre esse ou aquele, mas, na verdade, trata-se de um sujeito que transita entre esses pólos, cujas características coexistem simultaneamente.

Sobre processos de formação, Estrela (2002) apresenta reflexão sobre uma experiência, na qual observa a questão da investigação como uma estratégia de formação contínua de professores. A autora propõe seu estudo por julgar que a escola está em transformação, reflexo também de mudanças ocorridas na sociedade. Para o professor, ela entende que essas mudanças implicam uma "nova profissionalidade" que requer atitudes de questionamento crítico, cooperação, capacidade de iniciativa, abertura à mudança e responsabilidade ética. Julgamos importante incluir esse estudo, embora realizado em instituições de nível não universitário, por sugerir esse apelo para a busca por um novo profissionalismo do trabalho docente, apresentando palavras de ordem tais como acabamos de mencionar (cooperação, iniciativa etc.). Concordamos com a autora quanto à questão da mudança de atitude educacional. É necessário agregar novos sentidos e concepções à educação, à formação etc. Sabemos que todo discurso é heterogeneamente constituído, no entanto, a incorporação (não intencional, portanto) de palavras, conceitos e noções que circulam em uma esfera mundial ${ }^{26}$ ao contexto educacional parece-nos temerário se uma reflexão com profundidade sobre as suas implicações para a educação não forem consideradas. Dessa forma, sua pesquisa também nos provoca a olhar para nossas entrevistas

\footnotetext{
${ }^{26}$ Voltaremos a esse ponto, no próximo capítulo.
} 
com professores e alunos a fim de identificar se e como, discursivamente, esse apelo por uma "profissionalidade" docente se configura.

Um dos princípios orientadores, nesse estudo, reside na preocupação por uma formação de professores capaz de articular teoria e prática e que essa formação proporcione momentos e meios de análise para uma tomada de consciência crítica em relação a uma situação profissional concreta. Essa experiência de formação contínua foi designada pela pesquisadora como Projeto IRA (Investigação, Reflexão, Ação). Na verdade, essa proposta de investigação e reflexão tornou-se, ao longo dos anos, motivo de muitos estudos ${ }^{27}$ (NÓVOA, 1992/1995; SCHÖN, 1998/2000; PIMENTA; GHEDIN, 2002); seu uso, no entanto, parecenos banalizado, pois o professor é instado a refletir sobre sua prática, sem receber propostas, parâmetros ou pontos de partida para essa reflexão. Entendemos que é preciso refletir sobre a prática docente, mas a partir de qual perspectiva? Quem estabelece critérios para essa reflexão e como eles são estabelecidos? Que concepções de professor estão embutidas nessa prática de reflexão? Acreditamos que essas são algumas questões legítimas a serem investigadas ao se abordar o trinômio acima citado tão recorrente na educação. ${ }^{28}$

\subsection{A formação específica: alguns percursos já trilhados}

Iniciamos a seção, trazendo de volta a questão do ensino reflexivo. Tagata (2000) investiga como o discurso sobre essa questão e sobre Qualidade Total ${ }^{29}$ constitui a identidade dos professores de uma rede particular de ensino de língua inglesa, onde esses programas

\footnotetext{
${ }^{27}$ O ensino reflexivo preconiza uma reflexão sistemática sobre a prática do professor em sala de aula, proposta que poderia amenizar a divisão existente entre teoria e prática. Quanto a este tema, vale lembrar também o que Coracini (2003a, p. 310) indica em seu estudo da abordagem reflexiva no discurso do professor do Ensino Médio e Fundamental. Apesar de ser apontado por todos os pesquisados como uma "boa coisa", pois "coloca o desenvolvimento nas mãos dos próprios professores", a autora vê a impossibilidade de uma reflexão autônoma em virtude da insegurança dos professores ou ainda da memorização de idéias apresentadas em cursos de formação realizados. Entende também que o desejo de transmitir aos professores a capacidade de pensar criticamente pode ser sintetizado no "desejo de verdade e de controle de si e do outro".

${ }^{28}$ Apesar da relevância das questões, não nos ocuparemos em respondê-las neste estudo.

${ }^{29}$ Esse programa foi desenvolvido no Japão por um grupo de cientistas e engenheiros, a partir de idéias econômicas norte-americanas ali introduzidas logo após a $2^{\mathrm{a}}$ Guerra Mundial, numa tentativa de promover a recuperação social e econômica do país. No Brasil, a Gerência da Qualidade Total começou a ser difundida na década de 1980, para ajudar as indústrias brasileiras a enfrentar uma crise econômica nacional motivada, entre outros fatores, pela concorrência internacional. Iniciou-se nos Estados Unidos, a aplicação dessa proposta também em outras áreas (TAGATA, 2000). Na educação, portanto, ela constitui-se como um modelo gerencial, descrito como mais "humano", "participativo" e "motivador" (p. 47). De acordo com esse modelo, a escola passa a ser vista como "empresa", o aluno ganha status de "cliente", aulas e cursos passam a ser vistos como "produtos", professores são considerados como "técnicos" e diretores de escolas como "gerentes' (p. 109).
} 
foram implementados, quase concomitantemente. $\mathrm{O}$ pesquisador, inicialmente, apresenta e comenta algumas concepções de ensino reflexivo para, em seguida, descrever seu processo de implementação no contexto acima mencionado. Após comentar as semelhanças entre os dois programas, descreve também que tanto no programa de gerenciamento da Qualidade Total (GQT) quanto no de ensino reflexivo, os professores se sentiram "pouco à vontade" com os papéis que lhe foram atribuídos na instituição: "vendedor", “convencedor", "instrumento de propaganda", além da responsabilidade de "entreter o aluno", o que os levavam a serem vistos como principais responsáveis pela satisfação do cliente (aluno). Segundo a pesquisa, isso provocou sensações de confusão, incerteza e frustração nos professores que passaram a relacionar ensino reflexivo a treinamento ou até mesmo ao GQT.

Os resultados da pesquisa apontam para o insucesso da proposta de ensino reflexivo naquele contexto, pois além da falta de hábito dos professores com relação ao trabalho de pesquisa, eles também se deparavam com fatores institucionais que os limitavam ou os cerceavam quanto à escolha dos temas propostos para investigação em sala de aula - fato que mostrou a falta de autonomia do professor. Isso deixou também os professores em estado de autovigilância, levando-os a policiar suas atividades, pois, conforme conclusões apresentadas, essa instituição pesquisada adotou como parâmetro principal para medir o sucesso da reflexão realizada pelos professores a quantidade de alunos rematriculados no semestre seguinte. Tagata também conclui que o ensino reflexivo, no contexto analisado, não proporcionou aos professores a possibilidade de se verem como educadores ou intelectuais capazes de formar um pensamento crítico, pois além das relações entre sala de aula e contexto social não terem sido consideradas, houve a valorização do conhecimento de técnicas de ensino e da capacidade de solucionar problemas práticos em detrimento do questionamento dos sistemas de valores imbuídos em suas práticas pedagógicas.

Concluímos que os resultados apresentados por Tagata (2000) são representativos de uma situação conflitante, na qual os professores se deparam com propostas mercadológicas "inovadoras", edulcoradas para tornar a educação mais "produtiva" ou "comprometida". Vemos que essa situação é exemplar de um momento no qual visões da modernidade se deparam com conceitos da pós-modernidade. Podemos supor como uma das causas desse conflito aquilo que Bauman (1999a) designou como a desregulamentação e a privatização de tarefas e deveres. Isto é, o professor é, nesse caso, responsabilizado tanto pelo aumento, como pela redução de alunos na instituição. Tal visão pode ocasionar, no mínimo, uma ansiedade no 
professor com relação a seus propósitos educacionais, conforme sugerem Kiziltan, Bain e Cañizares (1993). Com efeito, os resultados trazidos por Tagata mostram exatamente isso. Como partimos da premissa de que somos perpassados por vários discursos, a pesquisa que ora resenhamos nos instiga, então, a detectar nos discursos que serão analisados mais adiante conflitos de natureza semelhante.

Em sua tese, Delibo (1999), primeiramente, recompõe as metodologias de ensino de línguas estrangeiras, a partir de uma retrospectiva histórica para, em seguida, apresentar as características gerais do curso responsável pela formação de professores e discutir os aspectos relativos à qualificação desses profissionais, no âmbito de uma instituição privada. Finalmente, sugere alguns caminhos para o aprimoramento da formação do professor de língua inglesa.

A hipótese que norteia seu trabalho diz respeito à necessidade de repensar o papel da língua materna como facilitadora para a aprendizagem "consciente e significativa" da língua estrangeira. Ele acredita que o uso do português nas aulas de inglês pode ser pensado como fator de "oxigenação" nos cursos de formação de professores. Para comprovar sua hipótese, o pesquisador, primeiramente, reflete sobre o conteúdo programático do curso analisado, concluindo que a fragmentação das habilidades lingüísticas em disciplinas estanques evidencia a inexistência de um trabalho de conjunto na elaboração dos planos de ensino. Somando-se a essa constatação, julga que o painel "crítico" na formação do professor de inglês deve-se, ainda, a alguns fatores, tais como: tempo exíguo (pouco tempo para processamento de informações), ausência de conhecimento prévio (falta do conhecimento formal de língua portuguesa como recurso facilitador), excesso de população (agrupamento excessivo de alunos), postura inadequada do aluno (transferência de responsabilidade da sua aprendizagem para o professor e/ou instituição), metodologia inadequada (sumários superficiais sobre a estrutura da língua) e resistência à língua materna (professores rejeitam o uso da língua materna como elemento facilitador).

Utiliza-se de questionários realizados com alunos do curso de graduação em letras (habilidades: inglês/português), nos quais levanta comentários e observações dos alunos iniciantes e concluintes. Esses depoimentos revelam grande nível de frustração dos alunos com relação ao conhecimento lingüístico (inglês e português) como também com relação ao preparo para a docência. Para o primeiro, os alunos propõem que a universidade deveria 
exigir "nível de língua" no exame vestibular, pois aqueles que "sabem" a língua, tiveram que "buscar fora da universidade". Com relação ao preparo profissional, apontam a "falta de prática” em sala de aula, pois ocorre apenas, no último ano, como estágio de observação, tendo uma carga horária restrita.

A fim de comprovar sua hipótese, Delibo (1999) aplica alguns testes para os alunos, nos quais detecta, entre outros resultados, que a gramática constitui a principal dificuldade com a língua inglesa. Os resultados revelaram também que os alunos que fizeram uso da língua materna como recurso auxiliar nos testes foram bem sucedidos. Basicamente, sua conclusão é de que os fatores responsáveis pelas circunstâncias problemáticas que permeiam a formação profissional dos alunos de letras são: o conhecimento lingüístico precário e o despreparo teórico-pedagógico. A partir disso, comenta sobre a importância da interdisciplinaridade, sugerindo que a lingüística aplicada, assim como a prática pedagógica, precisam estar interligadas com a psicolingüística, a sociolingüística, a pedagogia geral, entre outras. Critica, finalmente, o que chama de propaganda enganosa veiculada por algumas instituições que, almejando sucesso financeiro, tratam seus cursos de graduação como produtos que entram e saem de circulação, de acordo com o custo/benefício (medido por pesquisas mercadológicas) que cada um deles pode ou não trazer, transformando ainda o aprendiz em cliente.

Supomos que muitas das questões levantadas, na pesquisa acima, poderão convergir com nossa análise, especialmente, ao voltarmos o olhar para o discurso de professores e alunos sobre a formação de professores de inglês. Primeiramente, com relação ao painel "crítico" desenhado (tempo exíguo, ausência de conhecimento etc.). Em segundo lugar, a própria noção de formação e, por fim, sua crítica a respeito da perspectiva institucional que transforma "o aprendiz em cliente". O espaço de quase dez anos entre essa pesquisa e a de nossa autoria nos faz questionar as mudanças ou permanências de alguns dos resultados indicados, apesar das diferenças teóricas e metodológicas entre essas pesquisas.

Platero (2000), tendo como foco principal de atenção a Lei de Diretrizes e Bases (LDB) de 1996 e as indicações dos Parâmetros Curriculares Nacionais (PCN), no contexto do Ensino Médio, estuda o relato das experiências vividas por uma professora de língua inglesa. O ensino de inglês, nessa etapa, para a pesquisadora, envolve uma "revisão" do conteúdo do ensino fundamental e a preparação para o vestibular. Daí seu interesse em pesquisar em que 
medida as propostas dos $\mathrm{PCN}$, por preconizar o desenvolvimento de uma competência comunicativa, são úteis ao aluno. Primeiramente, a pesquisadora apresenta como avanço na Lei o “espírito flexibilizador", citado por Demo (1997/1999, p. 15), presente em vários trechos do documento. Além de "flexibilidade", a palavra "autonomia" também figura na LDB com relação ao nível curricular, tanto no Ensino Fundamental quanto no Ensino Médio. Quanto aos princípios fundamentais na organização curricular, as palavras de ordem são interdisciplinaridade e contextualização. ${ }^{30}$ Após análise desses termos no texto da LDB, a autora discorre sobre alguns temas discutidos nessa Lei, quais sejam: o papel do professor, o planejamento do curso, a escolha do material didático, competências e habilidades, e avaliação.

Alguns aspectos chamam nossa atenção nesse estudo com relação à leitura desses documentos. Primeiramente, a professora entrevistada (objeto do estudo de caso) relata que a administração da escola restringe o contato e leitura desses documentos. Outra questão trata da falta de iniciativa dos professores para "entenderem" os Parâmetros, segundo ela. Voltemo-nos a outros aspectos da pesquisa, tomando alguns fatos: a) o estudo focalizou apenas uma professora e como ela produz sentidos aos preceitos da LDB; b) na visão da pesquisadora, essa professora foi "especial", pois apresentava qualidades que diferiam da maioria dos professores do Ensino Médio, cuja tenacidade por continuar sua formação por meio de cursos de aperfeiçoamento, capacitação, palestras etc., é evidente. A partir desses dados, somos levados a acreditar que os exemplos de atividades sugeridas pela professora em sala de aula, somados aos sentidos atribuídos por ela aos conceitos da LDB, tendem a figurar como um modelo de interpretação e conduta para professores de inglês. Nessa pesquisa, a ênfase na formação permanente, acrescida do fato de essa professora ser identificada nominalmente, incluindo aí seu local de trabalho, ao nosso ver, epitoma as qualidades de um professor "modelo" de um lado, e instaura a criação de um segundo pólo, ocupado por professores que não se vêem contemplados nesse padrão. Esse mecanismo, ao invés de aproximar esses dois pólos, pode acabar por perpetuar a distância entre eles, fazendo com que professores não se vejam como "especiais" por algum dos motivos listados (diferenças na qualificação profissional, quantidade de cursos realizados, falta de experiência profissional etc.).

\footnotetext{
${ }^{30}$ Empreenderemos análise sobre essa questão de palavras de ordem em propostas curriculares no capítulo seguinte.
} 
Rodrigues (2005) coordena e acompanha um curso de formação continuada dedicado a professores de inglês do Ciclo I do Ensino Fundamental, isto é, nos anos iniciais de escolarização $^{31}$. Com isso, sua pesquisa mostra, por um lado, o processo vivido pela pesquisadora durante a elaboração do referido curso, e, por outro lado, o processo vivido pelos professores na construção coletiva de uma proposta curricular para o ensino de inglês nesse período escolar ${ }^{32}$. No momento da discussão sobre a escolha do que ensinar e de como ensinar, algumas concepções sobre a aprendizagem de língua estrangeira que os professores manifestavam foram coletadas por Rodrigues. Primeiramente, a concepção de que aprender uma língua estrangeira implica a habilidade de produzir, oralmente, frases corretas em inglês, portanto, o trabalho com a modalidade oral deve preceder o trabalho com a modalidade escrita. Outra concepção diz respeito à visão estruturalista de língua, isto é, o ensino de línguas deve ter um caráter linear, partindo do ensino de palavras para, em seguida, introduzir unidades maiores, ou ainda de estruturas sintáticas mais simples para as mais complexas. Outras questões, levantadas ainda durante a preparação do curso, surgiram em forma de lamento, revelando algumas concepções que esses professores tinham de si. Apesar do esforço, os professores queixavam-se de que os alunos aprendiam somente "algumas palavrinhas" em inglês. Além disso, incomodavam-se também por entender que as estratégias de ensino utilizadas (trabalho com músicas, jogos e histórias) ajudavam a reforçar uma noção de que o ensino de inglês é encarado como um momento de diversão. Isso fazia com que esses professores não se sentissem em uma posição confortável em relação aos demais colegas e membros da equipe pedagógica das escolas que atuavam por dois motivos. Do ponto de vista do conteúdo lingüístico, os professores achavam que ensinavam pouco, em virtude da falta de tempo; sobre sua inserção no projeto político-pedagógico da escola, sentiam-se diminuídos (como professores de inglês) ou menos importantes, em função de algumas medidas administrativas. Explicaram, por exemplo, que, em algumas escolas, as aulas de reforço ou de recuperação paralela aconteciam durante as aulas de inglês. Nesse contexto, na visão desses professores, a aula de inglês passou a constituir um momento de descontração, um bônus, ao qual somente alguns alunos tinham direito. Esses são alguns resultados que nos interessam para nossa pesquisa, pois acreditamos que revelam visões educacionais que são desenvolvidas

\footnotetext{
${ }^{31}$ A Lei n ${ }^{\circ} 9394$ (LDB), de 20 de dezembro de 1996, determina o ensino de, pelo menos, uma língua estrangeira moderna no currículo oficial da Educação Básica a partir do $5^{\circ}$ ano do Ensino Fundamental (BRASIL, 1996).

${ }^{32}$ Estabeleceu-se a leiturização como objetivo geral do ensino de inglês no Ciclo I. Esse processo pressupõe o trabalho com textos e não o ensino de unidades lexicais contextualizadas em frases ou pequenos diálogos para troca de informações (RODRIGUES, 2005, p. 129).
} 
e mostram reflexos na formação de professores no ensino universitário - nosso objeto de estudo.

Ferro (1998) reconstitui a trajetória da formação de professores de inglês em uma universidade pública. ${ }^{33}$ Para tanto, descreve a história da metodologia de ensino de inglês, a evolução do ensino de línguas no Brasil e a formação de professores de inglês na cidade de São Paulo antes e depois de 1934 (data da fundação da Universidade de São Paulo, local onde realizou a pesquisa). Analisa, enfim, a disciplina Prática de Ensino de Inglês e a formação de professores de inglês, sob a perspectiva da interferência de três modelos de formação profissional discutidos por Wallace (1991): o do Ofício, o da Ciência Aplicada e o Reflexivo. Segundo a autora, o primeiro modelo sugere a existência de um profissional especialista na prática da profissão, detentor de um "saber fazer" adquirido por meio da imitação de técnicas e recomendações ensinadas pelo mestre, daí a noção de perpetuação do ofício como um conhecimento que se passa de "geração a geração". No modelo da Ciência Aplicada, o conhecimento prático está ligado à escolha de meios apropriados para se obter objetivos específicos. Nesse modelo, problemas do ensino são pesquisados com base em conhecimento científico a fim de que resultados precisos possam ser obtidos. No último modelo, o professor tem um papel múltiplo, possuidor, além de conhecimentos e técnicas, de um conjunto de manifestações de talento, valores, intuição e sensibilidade.

De acordo com o levantamento histórico da formação pedagógica do professor de inglês concluído pela pesquisadora, o primeiro modelo implantado na instituição para esses professores foi o do Ofício, originário do modelo do professor primário do Instituto de Educação - antiga Escola Normal Caetano de Campos. Como os professores que atuavam na escola secundária eram considerados autodidatas e portadores de modelos de ofício diversos, tais como: advocatício, médico, religioso, ou mesmo professor primário, esse modelo foi dado como ideal. Como, também, com a fundação da universidade, não houve explicitação do modelo de ofício de professor secundário, houve então uma adaptação ou transferência do modelo de professor primário para o secundário. ${ }^{34}$ A partir de tal constatação, a autora passa a

\footnotetext{
33 A pesquisadora adotou como "eixo condutor fundamental" para análise da formação do professor de inglês a disciplina, então, denominada: Prática de Ensino e Estágios Supervisionados de Inglês. Recorreu ainda a diversas fontes, tais como: anuários, guias, programas e documentos dessa instituição, leis e registros de época, somados a depoimentos de professores e ex-alunos.

${ }^{34}$ Segundo Ferro (1998, p. 169), o fato de, na instituição investigada, a formação de professores ser considerada tarefa de segunda categoria contribuiu para o "atraso" na configuração de um modelo de formação de professor secundário.
} 
discorrer sobre momentos que, em virtude de interferências institucionais, legais, ou de desenvolvimento de áreas como lingüística e psicologia, ela entende como tentativas de modificações dos modelos de formação profissional acima aludidos. Mas, para o que nos interessa, vemos que nas suas conclusões, o modelo que prevalecia para o professor de línguas (incluindo o professor de inglês) é o modelo de Ofício. Ou, seja, um especialista com conhecimento técnico que após treinamento é capaz de exercer sua profissão, enfim, "um mero repetidor de bons exemplos, a serem reproduzidos após treinamento" (FERRO, 1998, p. 167). Na verdade essas conclusões datam de dez anos passados, mas acreditamos que podem nos ajudar a pensar sobre o discurso de professores e alunos das duas instituições pesquisadas que serão analisados mais adiante.

Para concluir esta seção, trazemos pesquisa de Baghin-Spinelli (2003), no qual a autora analisa processos identitários do professor brasileiro de língua inglesa em universidades públicas e privadas no Brasil. A exploração do espaço da formação ocorre por meio da $\mathrm{AD}$, tendo como objeto da pesquisa, "alunos-professores" da disciplina Práticas de Ensino de Língua Inglesa, nas universidades pesquisadas. A análise busca identificar algumas representações do sujeito sobre o professor de inglês (formado e em formação), da língua inglesa, da formação de professores de inglês, entre outras. Segundo a autora, a constituição da identidade do professor de língua inglesa, no contexto observado, "se dá em relação ao outro-nativo de língua inglesa primordialmente, ao outro-colega de sala de aula, e ao outroprofessor" (p. 196). Nessas relações, observa-se que o sujeito aprendiz de professor de inglês ocupa uma posição "embrionária”, conclui Baghin-Spinelli, isto é, no imaginário discursivo, o aluno brasileiro está sempre em fase de preparação, não sendo capaz de atingir a maturidade lingüística que vê no outro (falante nativo, colega e professores fluentes na língua-alvo). Um dos efeitos de sentido apontados trata daquilo que a autora chamou de "apagamento ou silenciamento da brasilidade", ou seja, para o brasileiro ocupar a posição de professor de inglês, é preciso deixar de lado, enquanto aprendiz, suas marcas genuínas. Notam-se também efeitos de valorização da vivência no exterior, sobretudo nos Estados Unidos da América e Inglaterra. Enquanto isso não acontece, adia-se a "aprendizagem" do inglês, restando ao aprendiz brasileiro ocupar "o lugar da falta e ou da falha" (p. 197), uma vez que o lugar da “completude” é ocupado pelo falante nativo de língua inglesa.

Conforme podemos observar, as representações discursivas trazidas no trabalho que acabamos de citar podem comprometer a noção de formação de professores de inglês. A partir 
do efeito de divisão existente no universo acima descrito, instaura-se a impossibilidade da formação enquanto a "falta" não for devidamente "suprida". Isso nos faz pensar na dificuldade de provocar a compreensão do papel do professor de inglês como educador, pois como não se consegue romper com a noção de que ele é um sujeito em constante defasagem, perdem-se de vista oportunidades educacionais.

\subsection{Situando a contribuição da nossa pesquisa}

Vale esclarecermos, diante do painel aqui desenhado, no qual revelamos preocupações que fazem parte do universo da formação de professores, de que modo nossa contribuição está inserida. Os trabalhos selecionados pertencem a diferentes perspectivas teóricas e filosóficas, mas todos trazem reflexões críticas sobre a formação de professores, abordando questões da constituição do saber do professor, sua relação com o cotidiano escolar (experiências didáticopedagógicas) e, ainda, a formação em si (pré ou em serviço). Poderíamos sintetizar que as linhas aqui esboçadas apontam para questões que envolvem a maneira como o professor é formado, como ele é constituído (saberes) e como realiza seu trabalho. Nosso estudo está voltado para a primeira dessas linhas, isto é, como ele se forma. Argumentamos, também, que nossa inserção nesse universo de pesquisa dá-se por meio da $\mathrm{AD}$, tendo como premissa um contexto que considera uma transição para o paradigma da pós-modernidade.

Quanto às pesquisas específicas sobre a formação de professores de inglês, norteadas, marcadamente, pelo paradigma crítico da formação reflexiva, vemos que as preocupações estão voltadas, especialmente, para o fazer pedagógico, ou seja, análises de procedimentos intrínsecos ligados à formação (estudos de caso, historização de disciplinas, análises de propostas curriculares etc.). Nossa contribuição também está inserida nessa dimensão, analisando a questão da formação por meio do discurso da formação, isto é, investigamos os efeitos de sentido que podemos depreender no discurso de professores-formadores ${ }^{35}$ e alunos sobre a noção de formar professores de inglês.

\footnotetext{
35 Empregamos a expressão "professor-formador" para fazer referência ao docente formador de novos professores.
} 
Para Moreira e Silva (1994), a pós-modernidade e, com ela, movimentos como a virada lingüística ${ }^{36}$ problematizam concepções que estão no cerne de nossas noções de educação e currículo. Concordamos com os autores e acrescentamos que vemos na área dos estudos lingüísticos, a importância da perspectiva discursiva por levar em conta a dimensão social e histórica da linguagem. Os pressupostos analíticos da AD propiciam ampliar nossa compreensão sobre as relações mediadas pela linguagem. Assim, no campo educacional, as relações entre os sujeitos envolvidos em situação de ensino-aprendizagem podem ser melhor compreendidas por meio da agregação de novos, ou deslocamentos de sentidos.

Dessa forma, pretendemos problematizar a noção de formação de professores de inglês e provocar os sujeitos envolvidos nessa relação, bem como na formação, de um modo geral, a revolver algumas maneiras com as quais analisamos e organizamos o currículo e, principalmente, os modos com os quais nos referimos à preparação docente, em especial, a do futuro professor de inglês. O caráter interdisciplinar da $\mathrm{AD}$ nos ajuda a perceber as minúcias que fazem parte das representações acerca da formação, do professor-formador e do aluno. Com isso, longe de tentarmos apenas expor a interioridade do universo da formação de professores de inglês, por meio de um pequeno retrato, desejamos inserir-nos nos debates educacionais, propondo a intensificação de diálogos entre vários agentes envolvidos na preparação e formação da profissionalidade ${ }^{37}$ do futuro professor de inglês, independentemente das vinculações científicas, departamentais, filosóficas ou políticas.

A noção de "função autor" elaborada por Foucault (1969/2006) nos ensina que nossa figura de autor deste trabalho é uma função discursiva, ou seja, organizamos e mostramos o modo de existência, de circulação e de funcionamento de determinados discursos. Contudo, sabemos que o "autor" sempre se manifesta por meio das "costuras" realizadas entre os discursos. Sendo assim, reivindicando a "autoria" do texto que nos cabe, apresentamos um diagnóstico da formação do professor de inglês, tomando o discurso político-educacional das Diretrizes Curriculares e o discurso didático-pedagógico nas duas instituições pesquisadas.

36 Conforme definição apresentada por Costa (2005, p. 140), “a expressão virada lingüística refere-se às movimentações no campo da filosofia em que o discurso e a linguagem passam a ser considerados como constituidores da realidade. Segundo as concepções que se afinam com a virada lingüística, nosso acesso a uma suposta realidade é sempre mediado por discursos que não apenas a representam, falam dela, mas a instituem. Quando se fala de algo também se inventa este algo".

37 Tomamos o termo no sentido em que é trabalhado por Estrela (2002, p. 141) para designar valores de cooperação, capacidade de iniciativa, questionamento crítico, abertura à mudança e responsabilidade ética. 
Diante disso, nosso trabalho aponta para trilhas que podem estar enfraquecidas ou obscurecidas frente a vários outros discursos que a pós-modernidade faz emergir.

Após circunscrição do nosso trabalho, voltemos nosso olhar para a questão do currículo, que, conforme já sinalizamos, é essencial para se pensar sobre a interioridade de um curso, no nosso caso, de formação de professores de inglês. 


\title{
CAPÍTULO 3
}

\section{O CURRÍCULO COMO ESPAÇO DA AMBIVALÊNCIA}

\author{
Zeus, do alto do Olimpo, determina o rumo dos acontecimentos e muitas \\ vezes os deuses enganam a nossa expectativa: o que se espera não se cumpre \\ e ocorre o que não se espera. \\ Eurípides. Medéia.
}

Conforme exposto, na Introdução, o fato de termos atuado no interior de um curso de formação de professores nos colocou frente a diversos dilemas inerentes a esse universo; dentre eles, a questão do currículo. O objetivo deste capítulo, então, é refletir sobre alguns trabalhos que envolvem questões de currículo, reformas educacionais e propostas curriculares, em nível nacional e internacional. Pretendemos, com isso, investigar as direções apontadas nesses estudos com relação a mudanças curriculares, quais as regularidades apresentadas e tendências de debates suscitadas, com o objetivo de promover articulações com nossa análise sobre as Diretrizes Curriculares, objeto do primeiro capítulo da Parte II.

Para tanto, dividimos o presente capítulo em dois segmentos. No primeiro (seções 3.1 e 3.2), que contemplará trabalhos estrangeiros, argumentaremos que a presença da ambivalência, nesse nível das políticas educacionais, acaba por revelar um elemento outro não previsto, inesperado, contingente. Buscaremos evidenciar também, durante a análise, ações que vemos como corporalizações daquilo que Bauman (2001, p. 38) sugere como sendo resultado da modernidade líquida: a "desregulamentação e a privatização das tarefas e deveres". No segundo segmento (seções 3.3 e 3.4), nós nos concentraremos nas pesquisas realizadas no Brasil, a fim de proporcionar uma recuperação das discussões recentes sobre a questão curricular, problematizar alguns desses resultados, apontar conexões com trabalhos estrangeiros, e refletir sobre aspectos que ainda deveriam ser contemplados ou mais detalhados no que tange à questão curricular. As condições de produção das Diretrizes Curriculares são apresentadas também, nesse segmento (seção 3.4), momento no qual exploraremos, igualmente, a ambivalência no discurso dos seus elaboradores. Finalmente, na última seção, formularemos algumas conclusões que serão retomadas, na Parte II deste estudo. 


\subsection{Reformas Curriculares: variações de um mesmo sentido?}

Para iniciarmos discussão sobre a questão do currículo, evocamos, inicialmente, a maneira como Popkewitz, especialista nesse assunto, encara o tema:

Vejo o currículo como um conhecimento particular, historicamente formado, sobre o modo como as crianças tornam o mundo inteligível. Como tal, esforços para organizar o conhecimento escolar como currículo constituem formas de regulação social, produzidas através de estilos privilegiados de raciocínio. Aquilo que está inscrito no currículo não é apenas informação - a organização do conhecimento corporifica formas particulares de agir, sentir, falar e "ver" o mundo e o "eu" (1994, p. 174).

A articulação desse conceito com a análise das Diretrizes Curriculares que faremos em momento posterior é de suma importância para compreendermos como esses documentos refletem maneiras de ver o aluno, o professor e seu trabalho, no nosso caso específico, o professor-formador e alunos do curso de licenciatura. Lindblad e Popkewitz (2004b, p. vii) vêem que reestruturações educacionais assumiram grande importância nas últimas décadas. $\mathrm{Na}$ área da educação, as mudanças estão relacionadas a aspectos como a descentralização, desregulamentação, accountability ${ }^{38}$ profissional, mercantilização (marketization), entre outros, com o objetivo de mudar as relações do Estado com a sociedade civil. A fim de indicar essa mudança do papel do Estado, que transfere para outros órgãos (públicos ou privados) a organização e a administração de instituições sociais, com base na teoria foucaultiana de governamentalidade, os autores adotam o termo governance (LINDBLAD; POPKEWITZ, 2004b, 2004c).

Lembramos que Bauman (2001) postula considerações semelhantes, sem, no entanto, mencionar questões educacionais. Mas, voltemos para a análise dos educadores com relação às reestruturações no campo educacional. Segundo eles, as mudanças ocorrem também nos programas de cursos de formação de professores. Em decorrência disso, as mudanças na área das políticas curriculares também apresentam modificações a fỉm de incorporar mudanças culturais, sociais e econômicas que vêm com palavras de ordem, tais como "sociedade do

\footnotetext{
${ }^{38}$ Decidimos manter o termo accountability em inglês em razão da complexidade do seu significado. No âmbito da administração pública, por exemplo, Campos (1990) advoga a impossibilidade da sua tradução para o português, por não ver na realidade social brasileira uma conjuntura que dê conta, na mesma proporção, do sentido que a palavra implica em inglês. Normalmente, seu uso está associado à responsabilidade social ou a uma atitude responsiva de prestação de contas (explicação, justificativa) de gestores públicos ou cidadãos comuns.
} 
conhecimento" (knowledge society) e "aprendiz por toda vida" ou "aprendiz eterno" (lifelong learner). Outra implicação do termo "reforma" (restructuring) é sua ligação com noções do perfil de quem é o aluno sob responsabilidade da escola e suas relações com a comunidade, a nação e processos globais. Enfim, vemos aqui que a questão da constituição da identidade do aluno é um tema que emerge sempre que se planeja uma reforma na área educacional.

Para esses autores, reforma educacional é um conceito de sentido mutante. Assim, nesse trabalho, os pesquisadores apresentam reformas educacionais em diversos continentes e como expressões de caráter global assumem características locais. Além disso, analisam também reformas em diversos países europeus, observando quais são as práticas discursivas que ordenam as diferentes reformas, em diferentes contextos educacionais. O objetivo dessa pesquisa não é avaliar a aplicabilidade das mudanças, mas sim analisar como as regras e padrões estabelecidos são possíveis de serem pensados na forma que são formulados. Para esse exercício, Popkewitz (1998) apresenta o termo "system of reason" que é utilizado para designar os princípios de regras e padrões de pensamento que governam, normalizam e naturalizam ações. Essas reformas são, portanto, apresentadas como um fenômeno global que trazem palavras de ordem com sentidos semelhantes em diferentes contextos e países. $\mathrm{Na}$ Inglaterra, por exemplo, expressões como "justiça social” e "negócios”, "individualismo competitivo", "membro de uma equipe" (social justice, business, competitive individualism, a team member) aparecem em reformas educacionais, assumindo um caráter de verdade, no qual não há controvérsias ou ambigüidades. Na França, noções de “integração social”, e "nova solidariedade entre classes sociais" (social integration and new solidarity between social classes) são apresentadas. Na Argentina e Taiwan, os termos recorrentes são "democratização" e "desregulamentação" (democratisation and deregulation) que aparecem combinados com a expressão "responsabilidade pessoal" (personal responsibility). Em Portugal, os termos encontrados em mudanças educacionais falam em "educação ao longo da vida e treinamento", "sociedade do conhecimento" e "globalização." (life-long education and training, knowledge society and globalization) Enfim, essas são algumas palavras e expressões que são encontradas quando questões de mudanças educacionais estão em andamento. Os autores trazem, desse modo, reflexões no sentido de observar como as questões de reforma educacional geram princípios com o objetivo de ordenar e governar as ações e a participação dos sujeitos envolvidos. Postulam, ainda, que as questões de reforma sempre apresentam conceitos com duplos sentidos, isto é, processos de inclusão, por exemplo, não podem ser analisados sem levar em conta problemas de exclusão que passam a ser 
inerentes aos processos de inclusão. As certezas estabelecidas nas reformas não podem ser avaliadas sem olharmos também para as incertezas inerentes a esses processos. É nesse movimento que intervimos com a noção de ambivalência, isto é, já que os deslizamentos de sentidos nas políticas educacionais (primeira das dimensões que analisamos) são inevitáveis, a questão que merece ser posta, então, é como aprender a conviver com essa bifurcação de sentidos, ou com a apresentação de uma realidade até então "inesperada", contingente nesse nível curricular. Essa é uma questão que pode nos ajudar a pensar nas reformas educacionais propostas no Brasil, especificamente, no caso do presente trabalho, nas Diretrizes Curriculares Nacionais, bem como no seu processo de elaboração.

\subsection{A transferência de deveres e os deslizamentos de sentidos das reformas curriculares}

Cabe-nos detalhar um pouco mais a pesquisa de Lindblad e Popkewitz (2004a) a fim de demonstrar como vemos a ambivalência apresentada nesses estudos. ${ }^{39}$ Observaremos alguns resultados que analisam processos que ocorrem em pares (inclusão/exclusão; certezas/incertezas; descentralização/centralização etc.) nos exemplos coletados em diversos países estudados. Iniciando pela Argentina, Dussel (2004), em suas conclusões, entende que as noções de "responsabilidade" e "autonomia", expressões que figuram em reformas escolares, abrigam discursos sobre administração que, aparentemente, são novos, mas, na verdade, envolvem temas antigos como obediência a regras, incluindo aqui, normas de conduta e respeito aos símbolos da pátria. Chen (2004) repensa a questão da descentralização nas reformas educacionais em Taiwan, observando como esses movimentos são readequados para contemplar conceitos globais, mas que, paradoxalmente, acabam mostrando a coexistência de conceitos locais, revelando, portanto, noções centralizadoras que mostram a continuidade histórica da cultura chinesa com suas raízes no Confucionismo.

Os próprios organizadores dessa coletânea de estudos, ao analisarem, em outro ensaio (2004b), reformas ocorridas na União Européia, argumentam que a descentralização é uma forma de individualização que visa administrar as incertezas. Os processos de descentralização são apresentados como mecanismos elaborados para monitorar, ordenar e

\footnotetext{
${ }^{39}$ Lembramos que, conforme esclarecemos, no Capítulo 1, esta é a primeira dimensão, na qual exploramos a presença da ambivalência.
} 
gerenciar reformas escolares. Ao mesmo tempo que a escola é vista como uma instituição injusta, há a promessa de, por meio dela, ser possível atingir igualdade e justiça na sociedade.

A análise apresentada por Muller (2004), sobre as reformas na África do Sul, trata das políticas de fusões institucionais que objetivam reduzir de 35 para 21, o número de instituições de ensino de terceiro grau no país, almejando aprimorar a qualidade e a eficiência do ensino. O pesquisador vê esse processo como decorrência de movimentos de globalização, no qual o Estado busca se eximir ou diminuir suas responsabilidades de mantenedora das universidades. Assim, com as fusões e as novas parcerias, as universidades podem contemplar influências de outros nichos do mercado que possam atender, futuramente, suas necessidades.

Um outro caso que mostra os efeitos da descentralização dos deveres do Estado para a sociedade civil vem da França. Dessa perspectiva, van Zanten (2004) analisa o aumento da autonomia atribuída a diversas instâncias políticas da sociedade (regiões, departamentos, municipalidades), instâncias importantes na área educacional (Reitorias, Supervisões Acadêmicas), como também mudanças nas relações de poder entre diferentes grupos da sociedade; professores e pais inserem-se nesse segmento. Esse último é o que lhe interessa nesse estudo, no qual observa que o Estado mantém o poder de formular e legitimar políticas administrativas, mas, no entanto, transfere a responsabilidade dos objetivos e princípios para os indivíduos, a escola etc. Nesse contexto, a pesquisadora investiga o aumento da representatividade dos pais no sistema educacional francês. Uma de suas conclusões é a distorção de preceitos de unidade e coerência em virtude da grande interferência dos valores e estilo de vida dos pais de classe média que, historicamente, detêm privilégios diferenciados em comparação com famílias de poder aquisitivo inferior. Embora a visão desses pais, oriundos da classe média francesa, não apresente poder de decisão em questões curriculares, pedagógicas ou de avaliação, na verdade, eles exercem significativa influência sobre aqueles que estão envolvidos nas decisões que abordam essas questões.

Popkewitz e Lindblad (2000), em outro estudo sobre a União Européia, analisaram também os sistemas de razão ${ }^{40}$ que regem as políticas de inclusão e exclusão na educação.

\footnotetext{
${ }^{40}$ Optamos por essa tradução para "systems of reasoning”, ao invés de "sistemas de raciocínio", conforme edição brasileira (Porto Alegre: Artmed, 2001), por entendermos que "razão" designa algo mais abrangente do que "raciocínio", sendo, portanto, mais apropriado para a noção que o conceito implica. No texto original (POPKEWITZ, 1998), variações como "systems of reason", "systems of rules", "forms of reasoning", "discursive practices" são empregados com bastante proximidade de sentido, cuja interpretação formulamos
} 
Entendemos que sistemas de razão são os mecanismos empregados para que um conceito seja formulado da forma que é apresentado, os raciocínios formulados que tornam uma idéia, conceito, princípios naturalizados ou aceitos como verdades inquestionáveis. Nesse trabalho, questionando o consenso de que há uma inclusão total possível, os autores circulam por diversos países europeus, analisando como processos ditos inclusivos também podem ser exclusivos. Questões de raça, gênero, processos migratórios, mercado de trabalho, entre outros, estão presentes nessas análises. Sobre inclusão e exclusão no mercado de trabalho, os autores mostram, por exemplo, alguns dados da Organização para a Cooperação e o Desenvolvimento Econômico (OECD). Um desses resultados discutidos vem de um estudo finlandês que revela processos de exclusão que se iniciam antes mesmo da conclusão da formação profissional. $\mathrm{O}$ estudo demonstra que apenas um pequeno grupo de estudantes que recebeu regularmente auxílio financeiro (sustenance allowance) teve acesso a uma escolha vocacional e conseqüente ingresso na carreira profissional.

Em Popkewitz (1998), encontramos outro exemplo de análise sobre reformas educacionais em sua avaliação sobre o Teach for America (TFA) ${ }^{41}$. Em 1990, esse pesquisador foi convidado para avaliar o TFA, cujas preocupações estavam centradas em determinar os "sistemas de razão" nas maneiras que a questão do sucesso e do fracasso era formulada. Ou seja, ele não estava interessado em determinar como o sucesso ou o fracasso ocorrem, tampouco identificar formas de sucesso ou fracasso e quais sujeitos podem assim ser classificados. Sua investigação buscou compreender como o discurso acerca da questão da criança urbana e rural foi construído.

O primeiro aspecto que salientamos nessa pesquisa é o fato de TFA ter sido gerado a partir de uma iniciativa privada, reforçando aspecto que temos evidenciado sobre a questão da iniciativa não pública para apresentar propostas de reforma para problemas sociais. Tal ação, na nossa visão, constitui-se em exemplo ilustrativo de uma descentralização ou desregulamentação de tarefas (BAUMAN, 2001), ou governance, para Lindblad e Popkewitz (2004b, 2004c). Nessa pesquisa sobre TFA, chama a atenção, igualmente, que o avaliador

no corpo do texto. O termo "discourses" é também usado no trabalho como sinônimo de "systems of knowledge" para designar as relações de múltiplos conhecimentos que governam as práticas dos professores. Esses sistemas de conhecimentos dão origem ao raciocínio que formam os objetos de reflexão. Com isso, essa pesquisa buscou verificar como conhecimentos pedagógicos constroem o professor que governa a criança.

41 TFA é apresentado em seu trabalho como um programa alternativo para a formação de professores, cuja graduação ocorrera em outras áreas do saber que não em educação, tendo como objetivo recrutar e treinar essas pessoas para atuarem em escolas urbanas e rurais nos Estados Unidos, onde houvesse escassez de professores. 
dessa proposta vê que, nas reformas contemporâneas, the moral domains of the soul are the site of struggle (POPKEWITZ, 1998, p. 25). Para ele, isso é traduzido no programa como discursos da salvação que "tornam” a criança um indivíduo justo, capaz e competente. Para isso, o estudo volta-se para a construção de binarismos levantados nos discursos dos professores participantes do TFA que colocavam de um lado as normas de inteligência e competência e, de outro, as crianças a serem "salvas" das escolas onde os professores treinados pelo programa foram alocados. A presença desses binarismos nos discursos dos professores faz surgir, para Popkewitz (p. 41), um "duplo" que é o espaço habitado por algo a ser resgatado. Tomemos exemplo fornecido de um professor entrevistado que coloca em um pólo um aluno "ambicioso". A partir da ausência de um segundo pólo, cria-se, discursivamente, um "duplo"; no caso, foi proposto "indiferente". O que esse teórico postula é que essa ausência (segundo pólo) reinscreve um elemento que deve ser resgatado. A construção dos "duplos" torna, desse modo, impossível para a criança ser "normal” ou estar na média, pois ela está inscrita em um espaço de oposição. Isso ocorre também com a questão que é central nesse estudo sobre a diferenciação entre criança urbana e criança rural, que funciona como um sistema de inclusão e exclusão. Não apenas por estar ligado a imagens cosmopolitas em um pólo, e imagens pastorais, de outro, mas também por esse discurso sobre educação rural e urbana evocar um espaço social no qual grupos étnicos, raciais e minoritários se apresentam como diferentes e devem ser normalizados.

Atentemos para mais um exemplo norte-americano, em estudo sobre No child left behind (NCLB). ${ }^{42}$ Cochran-Smith e Lytle (2006) lançam um olhar para a maneira como professores, o ensino e o papel dos professores são representados nesse documento. Por possuir caráter normativo e abrangente e com uma linguagem que evoca um sentimento de igualdade, segundo os pesquisadores, NCLB deve ser questionada, pois acreditam que visões sobre ensino e professores contidas nesse documento apresentam falhas, são lineares e reduzidas.

As críticas quanto à representação dos professores, nesse documento, são no sentido de que grande parte da responsabilidade pelo sucesso dos alunos depende dos professores.

\footnotetext{
42 Essa lei federal de 2001 tem como objetivo aprimorar o ensino das escolas norte-americanas a partir dos primeiros anos de escolaridade até o Ensino Médio (High School). NCLB está baseada em quatro princípios norteadores: accountability por resultados, maior possibilidade de escolhas para os pais, maior controle local e flexibilidade e ênfase no fazer funcional baseado em pesquisa científica (U.S. DEPARTMENT OF EDUCATION, 2007, tradução nossa).
} 
Transformar o professor na "solução" para os problemas da educação desvia a atenção de outras questões prementes, como pobreza e racismo, segundo os críticos. A grande ênfase no conhecimento conteudístico, além de trazer de volta uma idéia de que o conhecimento é transmitido, faz com que professores se tornem consumidores de produtos, implementadores de programas baseados em pesquisa, usuários de dados estatísticos, transmissores de saber e habilidades e corretores das dificuldades dos alunos determinadas por testes. The idea that knowledge is an object to be transmitted from outside experts to teachers, who then transmit it to students (p. 6). Enfim, de acordo com esses pesquisadores, NCLB apresenta o professor como um sujeito que, por não estar devidamente preparado para trabalhar com as "dificuldades" dos alunos, deve buscar (consumir produtos) para melhor detectar, nomear, corrigir, e aumentar os dados estatísticos sobre a escolarização. Dessa forma, então, ele é representado como o problema e também a solução para a educação, ou para tomarmos reflexão de Derrida $(1972 / 1991)^{43}$, veneno e remédio ao mesmo tempo.

Alguns aspectos nos chamam a atenção nessa análise. Primeiramente, a questão que temos tentado evidenciar sobre a transmissão da responsabilidade para o indivíduo, tanto para as conquistas como para as derrotas, em que a modernidade líquida faz acreditar. Ou seja, esse estudo sobre a NCLB nos faz ver que a ênfase na preparação profissional, segundo essa Lei, depende exclusivamente do professor. Se ele está enfrentando dificuldades na sua prática pedagógica, é porque desconhece pesquisas que possam auxiliá-lo em sua atuação em sala de aula. Sendo assim, ele deve ser, novamente, "treinado e re-treinado", pois, desse modo, ele poderá corrigir as "suas" falhas e da escola. Outra questão, igualmente próxima de análises anteriores, diz respeito aos conceitos que emergem de diferentes partes do mundo, fruto de uma sociedade cada vez mais globalizada, no qual a informação flui rapidamente. Há, segundo esses pesquisadores, uma lógica mundial sobre a competitividade presente em NCLB que se reflete na educação por meio da busca de melhores resultados, aumento de produtividade, aplicação efetiva de recursos disponíveis e índices estatísticos. Finalmente, a posição paradoxal do professor, que os pesquisadores desse estudo vêem no documento, como problema e solução, ou seja, uma construção binária, na qual ambos os pólos se retroalimentam, fazendo continuar uma cadeia interminável de ausência e complemento.

\footnotetext{
${ }^{43}$ Nesse trabalho, Derrida explora a oposição entre fala e escrita a partir de um texto do filósofo Platão, intitulado Fedro. Entre outras questões, comenta sobre a ambigüidade dos sentidos veiculados pela palavra de origem grega phármakon, que pode ser traduzida por remédio, ou droga curativa, mas também veneno. $\mathrm{Na}$ obra de Platão, a linguagem escrita está associada à palavra phármakon por apresentar essa característica "nociva" de ambivalência.
} 
Voltemos-nos, novamente, a alguns dados da realidade européia. Sobre a questão dos binarismos ou dicotomias que mencionamos anteriormente, Leite (2005) reflete sobre os desafios sociais da mudança do século XX para o XXI e suas implicações para o currículo e a profissão docente. A partir das mudanças curriculares ocorridas em Portugal, nos últimos anos do século XX, a pesquisadora esclarece que o discurso oficial sobre as reformas curriculares visa contemplar diversas realidades da população, em variados contextos sociais. Com isso, grande ênfase foi dada a vivências dos alunos e problemas oriundos de suas comunidades, com o objetivo de promover relações entre o saber escolar e a intervenção social. Conforme sinalizamos, anteriormente, essa não é uma postura inovadora, mas a vemos como um reflexo dos conceitos que passam a fazer parte de diferentes realidades pelo globo, ou como sugerem Lindblad e Popkewitz (2004a), são "traveling policies". A conclusão dessa pesquisadora portuguesa esclarece que, como no sistema educativo do seu país, professores são chamados para cumprir tarefas junto ao Ministério da Educação, "é preciso combater a tradicional separação entre os conceptores (os administradores da tutela educativa e os acadêmicos) e os práticos (os professores das escolas)" (LEITE, 2005, p. 134). Para ela, então, é importante que se reconheçam os mecanismos que geram a separação entre "conceptores" e "práticos" que acabam por dicotomizar os professores entre técnicos e práticos. Para finalizar, postula que, para promover uma renovação pedagógica, os professores devem assumir um papel de coautores do currículo. Como veremos a seguir, no Brasil, há também um processo semelhante para a construção de propostas curriculares. Ou seja, a elaboração desses documentos é também formulada a partir da congregação de professores de diversas partes do país e de formações variadas. Entre as conclusões desse estudo português, o fato que nos interessa é sobre a construção de uma dicotomia entre aqueles que elaboram e os que cumprem, ou devem cumprir, as orientações curriculares. Entendemos que esse jogo binário é também uma construção dos sujeitos que fazem parte dessa realidade, conforme observaremos em momento posterior.

Detenhamo-nos na reforma educacional, proposta no documento: White Paper on Education and Training ${ }^{44}$ (COMISSION OF THE EUROPEAN COMMUNITIES, 1995). Nesse documento, publicado pelo Comitê Europeu, o objetivo estava voltado para a educação, cujos subtítulos envolviam o ensino e a aprendizagem rumo a uma "sociedade da aprendizagem" (tradução nossa). Alguns temas levantados sobre esse documento, que nos

\footnotetext{
${ }^{44}$ White Papers são documentos elaborados para a Comunidade Européia com propostas para áreas específicas
} daquela sociedade. 
interessam para nosso trabalho, tratam da questão da identidade do aprendiz. Ou seja, quais características são valorizadas, nesses documentos, que determinam o tipo de pessoa que se pretende formar. Paralelamente a esse processo de levantamento de valores e princípios que devem formar um aprendiz, há a construção de um aprendiz não desejado; isto é, o fato de privilegiar determinadas características envolve a exclusão de outras. Vejamos algumas passagens, nas quais o perfil desejado do aprendiz de uma sociedade da aprendizagem é esboçado. $^{45}$

Sobre as novas tecnologias da informação e suas influências na sociedade européia, o trabalho é apresentado como um conjunto de "atividades inteligentes" que requer iniciativa e habilidade de adaptação. Em virtude de movimentos de internacionalização na economia, as preocupações do documento são no sentido de melhorar a competitividade e a qualidade de vida por meio de uma melhor distribuição de recursos pelo mundo. A respeito de valores culturais e sua transmissão para novas gerações, o documento aponta que esse não é apenas papel da escola, mas de todos os cidadãos. Dessa forma, enfatiza a importância da capacitação de jovens para buscarem novas respostas, mas sem esquecer dos valores humanos, propondo que a sociedade européia seja aberta, multicultural e democrática. Trazemos esses aspectos para a discussão, pois, nos documentos que analisaremos no próximo capítulo, temas como os aqui apresentados (novas "tecnologias", competências e habilidades) serão igualmente abordados. Nossas reflexões almejam observar a maneira como tais questões são tangenciadas e, principalmente, os deslizamentos de sentidos.

Da mesma forma, incluímos momentos que destacam o papel do ensino voltado para a inovação. Abordando, novamente, as novas tecnologias de informação, características que são normalmente esquecidas, mas que devem ser valorizadas pelos educadores, conforme aponta esse documento são: a observação, o uso do senso comum, da curiosidade e o desejo de experimentar. A capacidade de julgar, tomar decisões e escolher é apresentada como qualidade essencial para a compreensão do mundo. Tais qualidades contemplam a seleção de critérios para se fazer escolhas, a recordação de lições do passado e habilidade para avaliar o futuro. Esse aspecto sobre a avaliação do futuro nos interessa pela sugestão de que os educadores devem apresentar o mundo como uma construção inacabada para que se possa

\footnotetext{
${ }^{45}$ Nossas afirmações estão baseadas na análise do documento e em anotações de aula do professor Dr. Thomas S. Popkewitz, no curso Reform and change in curriculum and instruction, ministrado no Department of Curriculum and Instruction da University of Wisconsin-Madison, EUA, em 2007.
} 
cultivar um instinto para o futuro. Evocamos novamente aqui estudo sobre "conceitos itinerantes" (LINDBLAD; POPKEWITZ, 2004a, tradução nossa) quando nos deparamos com termos como flexibilidade, que é apresentada no documento como uma questão central para o ensino para que se possa atender diversos grupos da sociedade, cujos interesses também são variados. Conforme tentaremos argumentar, mais adiante, essas noções sobre inovação, flexibilidade, habilidade para avaliar o futuro são propostas decorrentes de uma nova conjuntura social e que despontam, concomitantemente, em diversas partes do mundo. Sendo assim, os caminhos aqui traçados por nós são no sentido de tornar exeqüíveis nossas problematizações terminológicas nos documentos que investigaremos, pois podemos também encontrar conceitos similares aos mencionados acima.

Para finalizar esse painel de estudos internacionais, em outro trabalho vindo da Argentina, Dussel (2005) comenta sobre hibridismo nas questões curriculares, trazendo pesquisa acerca da genealogia do termo e seus usos na teoria e história do currículo. Iniciando com o uso, no século XIX, pela botânica e zoologia, essa autora apresenta como o teórico póscolonial Homi K. Bhabha formulou o conceito de híbrido em sua teoria. Após esse painel histórico do termo, essa pesquisadora argentina assume como um dos traços da "'hibridação contemporânea' a rapidez com a qual opera para incluir distintos discursos e, portanto, a velocidade com a qual se perdem os marcadores originais do discurso" (p. 71). Traz como exemplo a reforma curricular argentina que foi proposta, inicialmente, a partir da reforma espanhola dos anos 1970, que, por sua vez, apropriou-se de reformas ocorridas nos Estados Unidos. Entendemos que sua afirmação sobre a "perda dos marcadores originais do discurso" é controversa, pois acreditamos no discurso como uma dispersão, não se tratando, portanto, da questão de investigar a origem, ou como a autora afirma, a marca original do discurso. Além disso, como a discussão envolve conceitos de hibridismo, que entendemos como uma transformação, na qual se podem ver características "novas", mas também reflexos do "antigo", supomos que analisar a maneira como ocorrem esses processos de transformação seja mais instigante em termos de pesquisas educacionais. De todo modo, tomamos seu exemplo, por acreditarmos que nos ajuda a mostrar alguns rumos das discussões curriculares na América Latina, como também ilustra esse movimento de conceitos itinerantes (LINDBLAD; POPKEWITZ, 2004a), já mencionado acima.

Algumas conclusões desse painel apresentado por nós demonstram que aspectos, aparentemente, opostos fazem parte de um mesmo processo. Assim, uma prática inclusiva 
também pode ser exclusiva, como um procedimento de descentralização pode, em última análise, reverter em centralização, como o consenso também pode instaurar conflitos que acabam por mostrar a divisão ao invés da unidade. Acreditamos que esses discursos presentes nas reformas educacionais, especificamente, na área curricular, aspecto que estamos tratando neste capítulo, circulam também em discussões no Brasil. Partimos do pressuposto de que no ambiente da pós-modernidade no qual vivemos, ocorre também no nosso país, uma delegação de responsabilidades do Estado para a sociedade civil, com a conseqüente implicação desse movimento na educação, nas reformas educacionais brasileiras, nos processos de formação de professores e mudanças curriculares. Passemos, desse modo, a olhar para alguns trabalhos, em âmbito nacional, que envolveram essa questão, com o objetivo de verificar se os resultados obtidos confirmam nossa premissa e, sobretudo, como isso se configura discursivamente.

\subsection{Algumas discussões no Brasil}

$\mathrm{Na}$ seção anterior, a partir de estudos de pesquisadores estrangeiros, mostramos algumas tendências de mudanças das relações do Estado com a sociedade civil (desregulamentação de deveres), e, por meio dessas mudanças, os deslizamentos de conceitos ocorridos (nossa primeira dimensão da ambivalência). Nesta seção, reunimos alguns debates envolvendo questões curriculares, no Brasil, com o objetivo de substanciar nossas reflexões acerca do tema e, a partir delas, ajudar-nos a transitar para a análise das Diretrizes Curriculares. Os trabalhos pertencem a diferentes matrizes teóricas e filosóficas, mas são, na maioria, pautados pelo paradigma pós-estruturalista e pós-colonialista.

Lopes e Macedo (2005a) reúnem discussões de vários autores, não apenas no Brasil, no campo do currículo, que apontam como necessárias em virtude das mudanças ocorridas na sociedade, provocadas por fenômenos como a "globalização econômica, mundialização da cultura e processos de transformação de identidades" (p. 9). Numa dessas discussões, de autoria das próprias organizadoras do trabalho (2005b), elas traçam um painel sobre a questão curricular no Brasil, a partir da década de 1920, quando as reflexões começaram a receber influências de teóricos norte-americanos. A partir de 1980, segundo elas, o pensamento curricular brasileiro foi influenciado por vertentes marxistas, com o surgimento da pedagogia histórico-crítica e pedagogia do oprimido. $\mathrm{Na}$ década seguinte, os estudos sobre currículo passaram a ser marcados por um viés sociológico, sendo ele mostrado como um espaço, no 
qual relações de poder estão imbricadas. Incorporando abordagens pós-modernas e pósestruturais, nomes como Foucault, Derrida, Deleuze, Guattari e Morin passaram a fazer parte das discussões curriculares. Lopes e Macedo (2005b, p. 47-48) vêem, finalmente, o campo do currículo no Brasil, nos anos 1990, marcado pelo hibridismo, em virtude da diversidade de tendências teóricas e o rompimento/incorporação de sistemas culturais diversos nesse campo. Trazem como decorrência desse hibridismo a "reterritorialização de discursos produzidos fora do campo educacional". Concluem que, dessa forma, os discursos presentes nos debates sobre currículo propiciam o surgimento de novas identidades, fazendo com que a teorização acerca desse tema se torne uma área difusa, com um contínuo deslizar entre diversos campos de conhecimento.

Corazza (2005) explica o significado de um pós-currículo ou currículo da diferença, ou seja, um currículo que é pensado à luz das teorias pós-críticas em educação. De caráter mais descritivo, seu ensaio enumera características desse tipo de currículo, sem, no entanto, apresentar análises de como essas características são vistas em propostas curriculares. De acordo com descrição apresentada, um pós-currículo rejeita currículos oficiais de governos neoliberais. Esclarece também que um pós-currículo escuta a fala dos diferentes e integra essas diferenças em seu corpus, sendo dessa forma, democrático e participativo. Em suma, um pós-currículo nada promete aos educadores e educandos; no entanto, garante a eles que suas condições de analistas críticos das culturas e de intelectuais serão intensificadas.

Sem também apresentar análise de propostas curriculares, mantendo um caráter mais normativo, Costa (2005) adverte sobre contribuições que os estudos culturais podem trazer para as discussões sobre currículos escolares. Comenta sobre a importância das abordagens pós-estruturalistas, apresentando como exemplos a desconstrução e o afastamento de conceitos baseados em binarismos. Acrescenta que seu trabalho tenta mostrar maneiras pelas quais descrevemos o mundo por meio da linguagem e, desse modo, "modelam amplamente nossa compreensão sobre por que e como as coisas são como são" (p. 143). Essa proposta nos interessa, mas reiteramos que, no trabalho dessa pesquisadora, não encontramos contribuições sobre esse modo de análise.

Nessa mesma direção normativa, Canen (2005) tece reflexões sobre os desafios que o multiculturalismo coloca para as reformas curriculares. Segundo sua análise, é cobrada da educação, e por conseqüência do currículo escolar, a formação de cidadãos "abertos para o 
mundo, flexíveis, tolerantes e democráticos" (p. 176). A partir dessa premissa, a pesquisadora tenta responder como preocupações multiculturais aparecem nas propostas curriculares. Suas reflexões são apresentadas como uma lista de preceitos a serem combatidos para evitar a cristalização de preconceitos que as práticas curriculares que se pretendam multiculturais tentam suprimir. Um dos exemplos demonstrados pela autora acerca de sentidos e perigos do muticulturalismo diz respeito ao "folclorismo", isto é, a redução das questões multiculturais a valorização de costumes, festas ou outros aspectos folclóricos de grupos culturais diversos (Dia do Índio, Semana da Consciência Negra etc.). Concordamos com algumas reflexões postuladas, no entanto, novamente ressentimo-nos de análise mais direcionada para uma proposta curricular, fato que torna seu ensaio um guia de procedimentos para se pensar na construção de um currículo que contemple questões multiculturais.

Ferraço (2005), a partir de reflexões sobre o cotidiano escolar, problematiza a noção de currículo prescritivo. Analisando formulações de estudantes e professores do ensino fundamental, bem como fragmentos de livros didáticos e paradidáticos sobre ciências, o pesquisador investiga os diferentes valores, ideologias, lógicas embutidos nesses exemplares de discurso. Uma de suas conclusões é de que o currículo deve ser pensado a partir "do que é de fato realizado nas salas de aula" (p. 33). Apoiando-se no conceito de "tradução" de Homi K. Bhabha, o pesquisador salienta a importância de ler, discutir e pensar sobre os currículos sem omitir a participação dos "sujeitos anônimos do cotidiano", que irão efetivamente atribuir significados às prescrições curriculares. Concordamos com o conceito de leitura do currículo como processo de construção de sentidos, no entanto, essa questão de "pensar sobre o que é de fato realizado na sala de aula", conforme sugere o pesquisador, pode acabar por enfatizar a dicotomia teoria/prática, com a valorização dessa última, em detrimento da primeira.

Analisando o processo de criação curricular, Oliveira (2005) argumenta que as modificações apresentadas nos currículos e nas atividades de formação de professores não apresentam grandes inovações. A autora entende que as reformas funcionam, na verdade, como "um movimento de horizontalização das relações entre aqueles que desfrutaram do direito de ser reconhecidos como produtores de saber" (p. 44). Segundo sua perspectiva, portanto, o caráter prescritivo dos documentos curriculares é uma tentativa de solidificar práticas produzidas rotineiramente por aqueles que desfrutam do poder de se conclamarem habilitados para falar sobre o que falam. Sua argumentação não nos parece tão inovadora, no entanto, gostaríamos de chamar a atenção para sua conclusão de que mais importante do que 
criar normas é preciso criar maneiras de ampliar o diálogo e a interação na academia a fim de melhor compreender por que as práticas docentes são realizadas da forma como são.

Reflexão sobre a questão da alteridade no currículo escolar é trazida por Carvalho (2005), que inicia pela diferenciação entre currículo formal (Parâmetros Curriculares Nacionais, projetos político-pedagógicos, propostas estaduais ou municipais), e currículo vivido ou praticado. Esse termo, segundo a autora, é usado para designar as relações de poder, cultura, escolarização que efetivamente se manifestam no cotidiano escolar. O que a referida pesquisadora sugere como alteridade no currículo é o fato de o sistema educacional estar apoiado em oposições binárias (desejável/indesejável; legítimo/ilegítimo) e que tais operações acabam sempre por descaracterizar o segundo elemento. Dessa forma, conclui que pensar a questão da alteridade no currículo implica repensar as diversas relações culturais, pedagógicas, sociopolíticas e estruturais da escola. Compreendemos a preocupação, bem como acreditamos na necessidade de repensar, conforme alertou a autora, sobre as questões binárias que estão presentes na realidade escolar. Poderíamos ainda acrescentar oposições entre teoria/prática, pesquisa/ensino, qualificar/desqualificar e outros tantos binarismos com os quais nos deparamos no cotidiano da escola e do ensino. Vendo nessas posições binárias construções que se cristalizam e se instituem no fazer dos sujeitos envolvidos (alunos e professores), supomos que a falta de conscientização dessa construção nos impede de perceber que esses binarismos são construídos a partir da mesma fonte.

Não acreditamos que as reformas educacionais possam ser pensadas como panacéias para questões pedagógicas, curriculares, e de formação de professores. A idéia defendida por nós é de que a complexidade inerente a qualquer reforma curricular deve ser amplamente discutida por todos os sujeitos envolvidos no processo educacional. Ignorar que elas existem, ou supor que elas não nos dizem respeito, não levam a uma reflexão sobre como o fazer educacional significa para alunos e professores. Rejeitar esses documentos por serem prescritivos não é uma postura crítica. Encará-los com criticidade, no nosso julgamento, significa envolver-se com eles a fim de procurar entender como eles podem fazer sentido no contexto específico de cada realidade escolar. Desse modo, não é suficiente rejeitar uma prescrição curricular por achá-la hegemônica ou distante da realidade escolar dos sujeitos envolvidos, mas é possível pensar sobre ela, de uma perspectiva foucaultiana, tentando entender como foi possível de ser proposta da maneira que se apresenta. Tal postura poderá surtir efeitos no fazer educacional de cada professor. Considerando que vemos esse fazer 
como fruto de uma lógica prescritiva interna de cada docente, muitas vezes, ele se configura como "natural", não se conjugando com uma prática normativa exterior. Colocar, portanto, esse fazer em questão poderá, por fim, ajudar o educador a refletir no modo como, ao longo do tempo, ele também adquiriu o poder ou o direito para fazer, agir e ensinar da forma que o faz.

\subsection{Diretrizes Curriculares: suas condições de produção}

Passemos para outra seção, na qual discutiremos as condições de produção das Diretrizes Curriculares, a fim de estabelecer articulações com a análise documental que será apresentada no primeiro capítulo da Parte II. Para isso, entrevistamos dois professores universitários que fizeram parte do comitê que elaborou as Diretrizes Curriculares. O primeiro deles participou do comitê elaborador das Diretrizes Curriculares Nacionais para a Formação de Professores da Educação Básica $\left(\mathrm{DCF}^{46}\right)$, e o segundo, do comitê elaborador das Diretrizes Curriculares para os cursos de Letras (de ora em diante DCL). As questões propostas para ambos foram:

1) Como foi o processo de elaboração das Diretrizes?

2) Houve algum tipo de pressão externa, interferência de natureza não educacional na elaboração do texto?

3) Quais as expectativas quanto à aplicabilidade dessas Diretrizes nos cursos de licenciatura?

Esclarecemos, inicialmente, que pretendemos observar como os discursos desses sujeitos revelam o que Foucault (1979/2003c) chamou de governamentalidade. Em outras palavras, como vemos as etapas da elaboração das Diretrizes como um conjunto de procedimentos e estratégias que irão controlar ou fazer com que os cursos pareçam mais uniformes.

Segundo o primeiro professor entrevistado, as DCF nascem de um trabalho que começa na Secretaria de Educação Fundamental e não na Secretaria de Educação Superior, como poderia se supor. O ponto de partida para o início de sua elaboração foi provocado pelas

\footnotetext{
${ }^{46}$ Abreviatura empregada para fazer referência a tal documento, conforme esclarecido no Capítulo 2.
} 
discussões das equipes que faziam parte do Ministério da Educação (MEC) com professores da rede oficial. Segundo relato, nas visitas empreendidas a escolas, pelas equipes do MEC para discutir os Parâmetros Curriculares Nacionais (PCN), observou-se que, nessas discussões, elogiava-se a boa formulação e filosofia dos PCN, no entanto, uma questão "fundamental" era enunciada pelos professores: "quem vai dar essa aula?" A espontaneidade e a aparente simplicidade da pergunta representaram, na verdade, a força motriz para se pensar que havia, ainda, uma questão mais importante que merecia igual ou maior relevância: a formação de professores. Elaborou-se, então, o que foi chamado de Referenciais para Formação de Professores, ainda no âmbito da Secretaria de Educação Fundamental. Esse trabalho ocorreu de forma concomitante com a discussão das Diretrizes Curriculares para os diferentes cursos no âmbito da Secretaria de Educação Superior. O fato de o produto dessas discussões ter sido disponibilizado por meio virtual fez com que a comissão responsável pelos Referenciais para Formação de Professores pudesse acompanhar a evolução desse esboço das Diretrizes Curriculares. O que se percebeu, então, é que havia uma ausência da preocupação com a formação de professores nessas Diretrizes. Elas não apresentavam a consistência esperada para esse tema. Foi dessa análise, então, que nasceu a idéia de elaborar um documento que propusesse Diretrizes Gerais para Formação de Professores. Um dos conceitos que fundamentam essas Diretrizes é a noção de competência, que, segundo o primeiro professor entrevistado, um dos membros da comissão responsável pela elaboração das Diretrizes Curriculares para a Formação de Professores (de ora em diante $M \mathrm{MCF}^{47}$ ), é a capacidade de se "apropriar do acúmulo de conhecimentos e ter liberdade de usá-los em situações da vida real”.

Segundo MDCF, essas Diretrizes almejam, desse modo, a defesa de uma idéia de professor como profissional possuidor de um instrumental próprio que envolve o conhecimento de como o aprendiz pensa a fim de apoiá-lo no desenvolvimento do pensamento. Isso fez a comissão elaboradora julgar que essas Diretrizes deveriam delimitar as características da profissão docente, daí a importância da noção de competência que as fundamenta. Esboçou-se, então, um documento inicial que foi apresentado para as comissões de especialistas das diversas áreas de conhecimento. As discussões oriundas desses encontros refletiram uma divisão existente entre "o povo da educação e o povo dos institutos das áreas específicas", que, de acordo com MDCF, é um enorme obstáculo para a melhoria da

\footnotetext{
${ }^{47}$ Adotamos a referida abreviatura para designar o membro do comitê organizador das Diretrizes Curriculares Nacionais para a Formação de Professores da Educação Básica (DCF), com o objetivo de facilitar a leitura.
} 
qualidade da formação de professores no Brasil. Seu argumento é de que não deve haver disparidade entre "como eu ensino e o que eu ensino", deve haver uma maior aproximação entre essas "duas pontas". Nesse sentido, as Diretrizes foram pensadas para virem a ser um elemento "provocador" para essa aproximação. ${ }^{48}$

Assim como a comissão das DCF, no caso das DCL, a comissão não foi constituída com o fim específico de elaborar Diretrizes, de acordo com o segundo professor entrevistado. O trabalho dessa comissão consistia, basicamente, na avaliação de cursos já existentes ou de propostas para instalação de novos cursos. Desse modo, os membros da comissão de especialistas de Letras do MEC foram convidados para propor um documento que se chamaria Diretrizes Curriculares para os cursos de Letras, como uma seqüência das propostas iniciadas nas DCF. Como o trabalho básico dessa comissão incluía, por vezes, visitar instituições, essas visitas acabavam por fornecer um painel geral da situação dos cursos de letras das universidades privadas no país. Ou, para citar as palavras do entrevistado, um dos membros responsáveis pela elaboração das Diretrizes Curriculares para os cursos de Letras (de ora em diante $\mathrm{MDCL}^{49}$ ), "isso permitia que a gente se desse conta da enorme heterogeneidade que caracteriza o universo de cursos de instituições privadas”. Essa diversidade observada foi considerada durante o processo de elaboração das DCL, pois a equipe optou por fazer um texto que abordasse mais princípios, "sem definir ou especificar muito as coisas", postura que poderia atrapalhar ao invés de ajudar os cursos de letras, na visão da comissão. A filosofia do documento, então, passou a ser: desenhar um "panorama de flexibilidade" dos cursos de letras, fazendo com que os currículos pudessem contemplar demandas regionais. Enfim, foi um documento "mais genérico mesmo", explica MDCL.

Diferentemente das Diretrizes para o Ensino Fundamental e Médio que geraram mais discussão, no caso das Diretrizes para o Terceiro Grau, de acordo com MDCL, o trabalho foi

\footnotetext{
${ }^{48}$ Vemos a preocupação com a formação de professores, no campo das políticas públicas nacionais, por meio de normas tais como: Lei 9.394, de 20 de dezembro de 1996, que "estabelece as diretrizes e bases da educação nacional" (BRASIL, 1996), Lei 10.172, de 9 de janeiro de 2001, que "aprova o Plano Nacional de Educação" (BRASIL, 2001), Resolução CNE/CP 1, de 18 de fevereiro de 2002, que "institui Diretrizes Curriculares Nacionais para a Formação de Professores da Educação Básica, em nível superior, curso de licenciatura, de graduação plena" (CONSELHO NACIONAL DE EDUCAÇÃO / CONSELHO PLENO, 2002a) e a Resolução CNE/CP 2, de 19 de fevereiro de 2002, que "institui a duração e a carga horária dos cursos de licenciatura, de graduação plena, de formação de professores da Educação Básica em nível superior" (CONSELHO NACIONAL DE EDUCAÇÃO / CONSELHO PLENO, 2002b). Destacamos como exemplos de tal propósito a busca por promover maior articulação do saber específico com o saber pedagógico e o aumento da carga horária dedicada à preparação do profissional docente.

${ }^{49}$ Idem nota 46. No entanto, nesse caso, trata-se do membro da equipe elaboradora das Diretrizes Curriculares para os cursos de Letras (DCL).
} 
mais solitário. Uma das constatações apontadas por esse membro foi de que, ao avaliar propostas de instalações de novos cursos, seus projetos eram muito parecidos. Isso levou a equipe a descobrir a existência de firmas de consultoria especializadas em elaboração de projetos para novos cursos. Esse painel revelou, então, a grande carência de orientação das pessoas envolvidas no processo de criação de novos cursos. O trabalho diário da comissão (leitura de projetos de novos cursos, visitas a instituições de ensino superior) tornou-se, desse modo, o ponto de partida para a elaboração das DCL. Era preciso criar um documento capaz de explicitar qual deveria ser o perfil de um curso de letras, bem como questões fundamentais da área e quais aspectos deveriam ser considerados nos currículos. Vemos, nas intenções descritas, aquilo que Popkewitz (1998) denominou "pastoral care", ou seja, existe um cuidado, uma atenção revelada com relação aos cursos para que recebam as orientações necessárias a fim de que possam contemplar características do curso de letras. No entanto, esses documentos acabam por funcionar como um conjunto de procedimentos e estratégias que, em última análise, irão controlar, supervisionar ou avaliar os cursos para que pareçam mais semelhantes.

É necessário destacar uma questão que consideramos pertinente para o tipo de análise que o presente trabalho propõe e que diz respeito ao processo de elaboração do texto dessas Diretrizes. Há um consenso, no âmbito local ${ }^{50}$, de que tudo aquilo vindo de um nível central, representado aqui pelas comissões do Ministério da Educação, não é algo exeqüível, prático ou que diz respeito à realidade "local". Cria-se, nesse âmbito, uma resistência ou um conceito de inaplicabilidade porque aqueles que representam o nível central "desconhecem" realidades locais, ou seja, estão criando documentos, orientações ou leis fundamentadas numa realidade virtual, distante. No entanto, pudemos levantar nas entrevistas com os membros dessas comissões que não houve qualquer "inspiração transcendente", nem a importação de idéias prontas, tampouco uma tentativa de privilegiar determinados grupos, regiões ou instituições. Em ambos os textos (DCF e DCL), o ponto de partida foi o levantamento de questões, dúvidas, incertezas detectadas nas inúmeras visitas a instituições ou nas análises de projetos de cursos (novos ou para recredenciamentos) que faziam parte do trabalho diário dessas comissões. Segundo os entrevistados, durante o processo de elaboração das Diretrizes, não houve qualquer tipo de lobby ou interferência de natureza não educacional na tentativa de privilegiar determinados grupos ou entidades. Em ambas as comissões, os membros eram

\footnotetext{
${ }^{50}$ Empregamos essa designação para fazer referência a um grupo de pessoas ou entidades que, efetivamente,
} farão uso das Diretrizes. 
constituídos por professores de diferentes áreas de formação e de diferentes regiões do país que visitavam ou entravam em contato com professores também de diferentes áreas e de diferentes partes do país. Tal informação nos leva a acreditar que o painel levantado que serviu como ponto de partida para a construção do texto das Diretrizes foi amplo e revelador de uma realidade, marcadamente, de nível nacional. Esse aspecto é bastante enfatizado por MDCF que declara: "o que tem ali [nos documentos] é o meu sonho de professora... e em nenhum momento... nesse processo todo... houve alguma pressão do ministério ou do oitavo andar ou do terceiro andar" (informação verbal). Da mesma forma, MDCL garante que o trabalho foi executado com liberdade e que, em nenhum momento, durante o processo de elaboração do documento, houve pressão para que o texto tivesse determinadas características. Afirma ainda que, em nenhum momento, se lembra de algum outro membro da comissão ter relatado que foi procurado por alguém ou pressionado para que determinada expectativa fosse contemplada no texto.

Apoiando-nos também no modo como Popkewitz (2006) vê a presença do par "hopelfear" relacionado a reformas curriculares na atualidade, notamos nos discursos desses dois membros do comitê elaborador das Diretrizes e à luz desse conceito teórico, um panorama de investimento na formação (hope), mas, que sugere, concomitantemente, o medo da sua não-concretização (fear). Mobilizamos essa concepção por entender que funciona como decorrência de uma realidade em constante mutação, líquida ou fluida, na qual as identidades, conceitos e perspectivas se alteram rapidamente, apresentando desdobramentos de novas visões e sentidos num fluxo incessante, fazendo com que as direções sejam sempre bifurcadas.

Passaremos a destacar alguns pontos que julgamos melhor ilustrar o que expomos. Primeiramente, vemos aqui a noção de "pastoral care" como a tentativa de ouvir as inúmeras questões, dúvidas e ansiedades oriundas dos diversos cursos de letras do país. Há, portanto, um efeito de cuidado, de atenção para com a alteridade. Por essa razão, tal atitude constituiuse em "hope", ou seja, no investimento de que os documentos elaborados possam contemplar todas as necessidades, provendo aos cursos as orientações necessárias para seu funcionamento. Ao mesmo tempo que se investia nas Diretrizes, revelando a esperança (hope), portanto, havia a expectativa de que, após sua elaboração, esses documentos fossem mais discutidos e reelaborados, mas isso não ocorreu, segundo MDCL. Após desfeita a comissão, não se sabe de (ou se desconhecem) trabalhos que busquem verificar a maneira 
como esses documentos são lidos ou como, de maneira prática, são contemplados nas propostas de novos cursos de letras, por exemplo. Da mesma forma, com relação às DCF, a ausência de um trabalho de acompanhamento do impacto desse documento nos cursos de formação de professores é sentida pelo membro dessa comissão.

Para responder à questão sobre a aplicabilidade das Diretrizes, expectativas até mesmo pessoais como co-autores dos textos, os dois membros entrevistados revelaram preocupação parecida com relação à recepção dos textos. Para MDCL, a interrupção dos projetos com as mudanças de governo é encarada como um dos fatores responsáveis pela "redefinição de prioridades" e a conseqüente paralisação de políticas das várias áreas do governo, nelas incluídas as educacionais. Com isso, a penetração desse documento, a maneira como ele é "metabolizado" é algo totalmente desconhecido. Seu receio é que esse documento passe apenas a fazer parte do conjunto da legislação vigente sobre os cursos de Letras, disponibilizado pelo MEC, "esgotando-se no âmbito da burocracia", sendo referenciado apenas em momentos de criação e avaliação de cursos. MDCL espera que haja uma continuidade desse trabalho com as Diretrizes no sentido de acompanhar o impacto desse documento no dia a dia do curso, "na vida do curso". Suas sugestões são no sentido de que discussões e compartilhamento de experiências poderiam ser promovidas entre pessoas da mesma instituição ou não, podendo ter, por vezes, alguém do próprio MEC ou alguém que esteja mais familiarizado com os documentos. Sua expectativa é de que as pessoas que estão realmente atuando nos cursos de letras não deleguem a preocupação da formação com o profissional de letras apenas para os coordenadores de cursos. Que eles pensem sobre a responsabilidade de propor currículos que garantam a formação de um profissional cujo perfil é esboçado nas Diretrizes; no entanto, com relação a esse aspecto, o membro entrevistado não se mostrou otimista. Em todos os momentos da entrevista, o discurso desse sujeito é, portanto, carregado de expressões de "medo" e de incertezas. Medo de que o documento se torne somente uma lei do qual tomam conhecimento apenas aqueles que fazem parte de comissões responsáveis pela criação de cursos e que, desse modo, devem seguir os protocolos e procedimentos que o MEC preconiza. Medo de que a leitura e o "entendimento" das Diretrizes estejam nas mãos unicamente dos coordenadores dos cursos e não dos professores que deveriam refletir sobre a aplicabilidade dessas orientações.

De modo semelhante, MDCF esperava que o trabalho das Diretrizes continuasse em forma de um diálogo constante entre o MEC, Conselho Nacional de Educação e instituições 
de ensino, porque as Diretrizes trazem um "jeito novo de pensar a formação" e para isso necessita-se de um trabalho de exploração constante das mesmas. Tal expectativa, na nossa ótica, constitui-se em um investimento na educação, uma esperança, portanto, de mudança. Pela sua experiência, em visitas a instituições, observava-se que os currículos das instituições estavam pautados na lógica do acúmulo de conhecimento. Ou seja, as discussões tinham como ponto de partida o estabelecimento de quais disciplinas os cursos deveriam ter, ou qual a carga horária de cada disciplina. Do seu ponto de vista, não é essa a proposta das Diretrizes. Pelo contrário, o ponto de partida deve ser uma análise das demandas sociais, a reflexão inicial deve ser "quem é o sujeito que você precisa formar para os desafios que a nossa sociedade tem hoje?" Para que isso ocorra, um projeto de curso só será efetivo se começar a ser pensado "pelo lado de fora dos muros da escola", enfim, a partir da necessidade detectada na sociedade. Primeiramente, é preciso pensar sobre a constituição de um determinado perfil de profissional, para, em seguida, pensar sobre as competências que esse profissional precisa desenvolver. Após esse processo, deve-se pensar sobre quais as áreas de conhecimento precisam estar presentes nessa formação. Só após essa reflexão, segundo MDCF, é que se pode discutir sobre disciplinas específicas para o curso. Como é possível perceber, esse é um trabalho de muita reflexão e que só pode ter andamento se houver interesse não apenas dos órgãos oficiais para acompanhamento, mas também de todos aqueles envolvidos no processo de formação de professores. Porém, MDCF sugere a ausência de possibilidade para que isso ocorra, ao relatar que a formação de professores não é mais preocupação da Secretaria de Educação Superior e que desconhece se essa área ocupa algum outro setor do Ministério da Educação. Vemos aqui o caráter de incerteza, de medo, portanto, apresentados concomitantemente. Há esperança no sentido de se pensar a formação de maneira diferente, mas junto com essa visão, o medo, a desesperança do esquecimento, da interrupção das metas.

Quanto à questão do conteúdo dos cursos, MDCL traz também reflexão sobre o papel do professor e do perfil do aluno do curso de letras. Sua expectativa é de que, hoje, o papel do professor na universidade deve ser totalmente redefinido; a atitude de garantir apenas o ensino do conteúdo deve ser revista. Admite que o conteúdo não deixou de ser importante, mas é preciso questionar qual conteúdo deve ser considerado na elaboração do curso. Também acredita que as Diretrizes não funcionam como uma "camisa de força", pois elas permitem que o curso possa "respirar", ou seja, há flexibilidade, mas isso precisa ser discutido entre todos aqueles envolvidos nos cursos de graduação. Por isso sua ênfase de que o trabalho das Diretrizes não se esgote apenas na burocracia. Notamos, novamente, nesse momento, esse 
sujeito revelando sua certeza, sua esperança de que a flexibilidade presente nas Diretrizes não tornará os cursos limitados. No entanto, sua queixa é de que há um individualismo e um comodismo muito grande por parte dos professores que acabam trabalhando de forma muito solitária, sem integração entre os conteúdos das diversas disciplinas de um curso. Entende que um dos motivos desse comportamento é a questão das diversas demandas de dentro e também de fora da universidade. Com esse painel, fica difícil congregar o corpo docente e coordenadores para uma discussão da maneira que as Diretrizes sugerem. Outra questão também levantada é de que muitos professores do ensino superior estão mais preocupados com a pós-graduação, fazendo com que os cursos de graduação sejam "tocados" como sempre foram, levando cada professor a ministrar sua disciplina da forma como acha que deve ser. MDCL acredita na importância do conteúdo, mas a questão central, segundo ele, é a necessidade de se pensar sobre a organicidade do curso. Esse é, portanto, outro momento de medo no discurso analisado. Há a esperança de que, por ser um documento "genérico", ele possa ser flexibilizado e adequado as mais diversas regiões do país pelos mais diversos cursos. Entretanto, pelos motivos acima listados, há também o medo de que ele se perca no meio do processo burocrático-administrativo das universidades.

Outra decorrência desse aspecto anteriormente citado é a questão do perfil do aluno do curso de letras, detectado por MDCL, mas em nível mais local. Acredita que a falta de uma visão mais global do curso, da convivência e da interação das diversas disciplinas deixa os alunos à mercê da própria sorte. Segundo MDCL, uma pequena quantidade de alunos que desenvolvem trabalhos de iniciação científica acabam entendendo um pouco mais sobre as questões relevantes na área de letras, e, acabam, por fim, entendendo melhor o currículo. É importante salientar que esse é um exemplo do universo da instituição a qual MDCL está vinculado. No entanto, acreditamos ser um dado importante para o desenvolvimento do nosso estudo, pois entendemos que a grande maioria dos alunos não tem acesso à iniciação científica, principalmente nas instituições privadas, fazendo com que essa compreensão do eixo curricular (supondo que haja) só ocorra num momento futuro. Como postula MDCL, os alunos atribuirão sentido a conhecimentos adquiridos na universidade apenas após sua inserção no mercado de trabalho: "eles eventualmente vão repensar tudo que fizeram e o que aconteceu na universidade". Nesse último momento, então, detectamos que apesar do fato de as Diretrizes fornecerem um leque variado de opções para a elaboração do currículo dos cursos, o que na visão desse sujeito se revela como sendo uma esperança, a aposta de uma maior abrangência das orientações, há, ao mesmo tempo, o medo de que a grande maioria dos 
alunos não consiga depreender a organicidade do curso, fato revelador, portanto, de um aspecto que falha, ou o medo da não-abrangência.

\subsection{Sintetizando as reflexões}

A partir deste momento, reiteramos pontos de interesse, ora apontados, que nos ajudarão nas análises desenvolvidas na segunda parte deste trabalho. Antes, porém, retomamos reflexões de Bauman (2001), anteriormente citadas, a respeito da desregulamentação e privatização das tarefas e deveres, que são apresentadas como fruto da transição da modernidade sólida para a líquida. Como vimos, esse sociólogo argumenta que um dos efeitos sentidos dessa transição está na maneira como direitos sociais tornam-se deveres individuais. Atentemos mais uma vez para suas palavras: "nós, humanos, nos encontramos por nossa própria conta" (p. 37). Outrossim, evocamos discussão de Foucault (2003c) sobre governamentalidade. Conforme já esboçado, esse pensador analisou como as táticas de reforma do Estado foram transportadas para a vida cotidiana por meio da arte de governar. Tais táticas de reforma englobam mudanças institucionais e a individualização de problemas sociais. Passemos à demonstração de como mobilizamos os referidos conceitos na análise.

Podemos encontrar exemplo ilustrativo dessa delegação de responsabilidades para o indivíduo no estudo de Cochran-Smith e Lytle (2006) sobre No child left behind. Conforme apontado, o professor é visto como problema, mas também solução para os problemas da educação. Ou seja, o aprimoramento do professor para "melhor" ensinar depende unicamente dele; se não o faz, deve receber a culpa pelos "desacertos", "fracasso" ou "insucesso" na sua profissão. Nessa perspectiva, um banco de sugestões, ofertas ou receitas prontas para aplicar está disposto diante do professor, cabendo a ele apenas escolher a "melhor" fórmula para ensinar. Outros exemplos igualmente óbvios sobre a responsabilização do indivíduo são encontrados em Muller (2004), que analisou as políticas de fusões institucionais sobre as reformas na África do Sul, e também em van Zanten (2004), que observou aumento da autonomia atribuída, por exemplo, aos pais, na sociedade francesa. Acrescentamos, ainda, o projeto de uma iniciativa privada, nos Estados Unidos, que resultou no programa Teach for America e análise sobre o White Paper on Education and Training, sobre a qual concluímos que as características desejadas (inovação, curiosidade, poder de julgamento e decisão) são também fontes propulsoras de capacitação do indivíduo para se autogerir. 
Outro aspecto que podemos observar, a partir dos estudos relacionados, diz respeito às observações apontadas por Lindblad e Popkewitz (2004a) sobre políticas itinerantes. Vimos que os conceitos recorrentes em diversos países, presentes em reformas educacionais que foram apresentados como decorrências de movimentos de descentralização e desregulamentação do Estado, também podem ser encontrados nos trabalhos sobre reformas curriculares no Brasil. À maneira de outros países, que elaboraram suas palavras de ordem (Inglaterra: individualismo competitivo; França: nova solidariedade entre classes sociais; Argentina e Taiwan: desregulamentação e responsabilidade pessoal; Portugal: sociedade do conhecimento e globalização), algumas palavras de ordem formuladas nacionalmente (hibridismo, multiculturalismo, alteridade) são também vistas como decorrências de movimentos de globalização econômica, mundialização da cultura, reterritorialização de discursos (LOPES; MACEDO, 2005a), ou, ainda, como movimento de horizontalização das relações de poder (OLIVEIRA, 2005). Enfim, entendemos que as discussões sobre reformas curriculares no Brasil são também pensadas de uma perspectiva que considera mudanças históricas, culturais, sociais e econômicas ao redor do mundo.

Outro reflexo da noção de conceitos itinerantes no Brasil pode ser determinado quando se pensa na questão do perfil dos professores ou dos alunos esboçados nessas mudanças curriculares. Na Inglaterra, por exemplo, conforme Maguire (2004), espera-se que o professor contemporâneo seja flexível, ambicioso e tenha um individualismo competitivo. Nos Estados Unidos, Cochran-Smith e Lytle (2006) entendem que o perfil de professor desejado no programa de governo No child left behind é de consumidor de produtos. Com relação aos alunos, no documento White Paper on Education and Training, a meta é tornar os jovens capacitados para buscarem novas respostas para uma sociedade aberta, multicultural e democrática. Há ainda o incentivo para que os educadores formem cidadãos com o desejo de experimentar, com poderes de julgamento e de decisão e com instinto para avaliar o futuro. Vemos semelhanças, também no Brasil, de algumas expectativas com relação à educação quando se espera a formação de cidadãos "abertos para o mundo, flexíveis, tolerantes e democráticos" (CANEN, 2005). Ou seja, observamos que a noção de flexibilidade se esboça como uma palavra de ordem na educação, bem como tolerância e conceitos próximos como alteridade, diferença etc., além de democracia. Da mesma forma, depreende-se que os alunos devam ser flexíveis, tolerantes e democráticos. Mas como isso acontece no interior de um curso de formação de professores? Como esses conceitos aparecem nos discursos de professores e alunos desse curso? Tentaremos encaminhar nossa discussão no sentido de 
encontrarmos respostas para tais questões. Do mesmo modo, pretendemos observar se encontramos sentidos que se aproximam dessas políticas itinerantes no discurso das Diretrizes Curriculares, foco do próximo capítulo. Sobretudo, almejamos pensar sobre as implicações sinalizadas para a formação de professores, dentro do contexto de redistribuição ou diluição de deveres e responsabilidades para o indivíduo, tendências que entendemos como frutos de uma sociedade pós-moderna, ou, nas palavras de Bauman (2001), líquida ou fluida.

Um terceiro aspecto que a seleção desses trabalhos suscitou reside na observação também de Lindblad e Popkewitz (2004a) sobre a constituição de conceitos duplos, ou visões que se desdobram em sentidos opostos nas reformas curriculares - efeito de uma ambivalência constitutiva - do nosso ponto de vista. Reiteramos algumas conclusões apresentadas em trabalhos pesquisados para melhor esclarecimento. Na Argentina, discursos sobre administração, aparentemente novos, envolvem, na verdade, de acordo com Dussel (2004), temas antigos com relação ao estabelecimento de regras e condutas. Em Taiwan, a questão da descentralização nas reformas educacionais acaba por revelar noções que são centralizadoras (CHEN, 2004). Popkewitz (1998) estudou as políticas de inclusão e exclusão na educação, nos Estados Unidos, em sua análise sobre TFA. Popkewitz e Lindblad (2000) observaram os mesmos mecanismos na União Européia. Também nos Estados Unidos, Cochran-Smith e Lytle (2006) analisaram que o professor é delineado como sendo o problema, mas também solução para a educação.

Esse mecanismo de desdobramento em posições duplas, opostas ou antagônicas nos faz pensar sobre os trabalhos brasileiros que foram mencionados. Ao afirmarem que a área curricular apresenta contínuo deslizar entre diversos campos de conhecimento, Lopes e Macedo (2005b) nos provocam a pensar sobre as escolhas dessas áreas que farão parte das discussões curriculares. Ou seja, como essas áreas são selecionadas? Quem estabelece os critérios para seleção das mesmas? Enfim, a prática das escolhas nos parece como o desenrolar de um processo que, ao tentar ser inclusivo, também se revelará exclusivo ao deixar de fora das discussões curriculares algumas áreas do conhecimento. Outros estudos, ainda (CORAZZA, 2005; FERRAÇO, 2005), a partir da visão baseada no paradigma "pós", que mostram, portanto, as possibilidades de inclusão de diversos pontos de vista nas discussões curriculares, na nossa perspectiva, são traídos em suas considerações por tornaremse normativos. No primeiro deles, a definição do indivíduo como analista crítico de culturas ou com potencial de intelectual público instaura um segundo pólo ocupado por aquele que 
fatalmente não será analista ou intelectual. Qual a designação, então, para esse indivíduo? A quem será atribuído o direito de definir como esse indivíduo será nomeado? Enfim, entendemos que a dualidade, a bifurcação é inerente a qualquer posicionamento crítico que se faça. O que não pode deixar de ser considerado é o grau de reconhecimento, anuência e envolvimento com essas divisões daqueles que estão inseridos nas discussões no campo curricular. No segundo deles, a discussão curricular a partir "do que é de fato realizado nas salas de aula", conforme apontamos, parece-nos sinalizar a valorização do que comumente é designado como "prática", que poderá encaminhar-se para a constituição ou o reforço da dicotomia teoria/prática. A ênfase na realidade da sala de aula, desacompanhada da percepção de que esse posicionamento pode estar excluindo o exterior da sala de aula, ou a não-prática (aquilo que não está sendo realizado na sala de aula) acaba por constituir ou reforçar uma visão dicotômica.

A respeito dessa constituição de conceitos duplos, ou visões que se desdobram em sentidos opostos nas reformas curriculares, por meio do par "hope/fear", levantamos, no discurso dos sujeitos envolvidos na elaboração das Diretrizes Curriculares, momentos que se apresentaram como antagônicos, que apostam na certeza, mas também revelam as dúvidas ou incertezas. Lembremos a maneira como os documentos foram apresentados como sendo "elemento provocador" entre "o povo da educação e o povo dos institutos das áreas específicas" (no caso das DCF), ou ainda como um "panorama de flexibilidade" (no caso das DCL). Vemos que, em ambos os casos, a perspectiva é de investimento num trabalho coletivo, no qual diferentes pontos de vistas podem ser contemplados. Entretanto, esses mesmos pólos de esperança se bifurcam, mostrando a incerteza (fear), quando os sujeitos revelam o medo de que esses documentos façam parte apenas da legislação vigente do órgão que os concebeu. Há, principalmente, a presença da incerteza, nos momentos em que as dificuldades para fazer com que professores se envolvam em discussões desses documentos são formuladas. Lembramos alguns motivos citados: demandas internas da universidade, individualismo dos docentes, desconhecimento, valorização da pós-graduação, entre outros. Finalmente, outro momento no qual percebemos a presença desse caráter dividido entre a esperança e o medo surge na questão da compreensão do currículo como um todo por parte do aluno. Embora haja uma proposta para a formulação de um currículo flexível, amplo, com mobilidade, a percepção dessa estrutura por parte dos alunos só é conseguida em um momento futuro ou se o aluno estiver envolvido em pesquisa a partir do início do curso. Como dissemos, isso nos parece privilégio de poucos, o que faz com que essa flexibilidade, 
essa aposta na inclusão de diversas perspectivas, pensada no momento da concepção desses documentos, acabe por configurar-se como uma incerteza, uma não-realização da abrangência almejada.

\subsection{Reformas Curriculares: para onde nos encaminhamos?}

Diante desse panorama de trabalhos de pesquisadores brasileiros, algumas questões prementes, no campo curricular, foram indicadas: a criação curricular, a problematização do currículo prescritivo, a noção de um pós-currículo, a inclusão de temas como estudos culturais, alteridade, multiculturalismo etc., no currículo escolar. Nossa questão levantada como título da presente seção é, deliberadamente, ambivalente. Justifiquemo-nos: em primeiro lugar, o percurso trilhado até aqui, as problematizações suscitadas funcionam como um arauto da análise das Diretrizes Curriculares, no próximo capítulo, que servirá como exemplificação, como a concretização dos pontos aqui mencionados (palavra de ordem, deslizar de sentidos, desregulamentação de deveres). Em segundo lugar, considerando os debates aqui expostos sobre a questão curricular e, acreditando na inesgotabilidade do tema, o que mais podemos acrescentar?

Moreira e Silva (1994), após reconstituírem a história dos estudos curriculares, apontam como central, nessa discussão, a compreensão do currículo não somente como elemento organizador do conhecimento escolar. Por isso, analisam suas relações com a ideologia, a cultura e o poder. Sendo o currículo perpassado por esses elementos, os autores salientam a importância de uma investigação a seu respeito de uma perspectiva histórica. Isto é, para eles, é imperativo "flagrar" os momentos históricos que possibilitam que os arranjos curriculares concebidos tornem-se naturalizados, investigando a contingência e a historicidade de tais "arranjos". Surge daí a importância do papel da virada lingüística, da linguagem e do discurso, como recursos capazes de descentralizar a soberania, a autonomia, a racionalidade do sujeito, e, conseqüentemente, da educação e do currículo. ${ }^{51}$

\footnotetext{
51 À época da produção desse estudo, os autores, apesar da importância de abordar a construção do currículo de uma perspectiva discursiva, notavam que tal abordagem não havia sido explorada de maneira suficiente. Outra crítica apontada tratava do descompasso com que as transformações ocorridas com as "novas tecnologias" (televisão, música, videogames, revistas) e a informática são abordadas nas discussões curriculares. Na opinião dos pesquisadores, abster-se da incorporação de uma compreensão dessas transformações à teorização curricular crítica significaria "entregar a direção de sua incorporação à educação e ao currículo nas mãos de forças que as utilizarão fundamentalmente para seus objetivos mercadológicos e de preparação de uma mãode-obra adequada aos fins de acumulação e legitimação.” (MOREIRA; SILVA, 1994, p. 33).
} 
Alguns anos após a publicação desse ensaio, Silva (1999/2001), volta a discutir a questão do currículo sob três perspectivas diferentes: como prática de significação, como representação e como fetiche. Considerando o impacto das teorizações pós-modernistas (pósestruturalismo, estudos culturais, virada lingüística), o autor, diferentemente do estudo anterior, que analisa o currículo como texto, o explora como exemplar de discurso, agregando, com isso, às suas reflexões, as relações sociais aí imbricadas. Daí o papel do currículo como prática de significação, isto é, como um campo de produção (“zona de produtividade") e de criação de sentidos sobre espaços e atividades sociais. A partir de tal visão, destaca, especialmente, o papel do currículo como formador de identidades sociais.

A concepção de currículo como representação colide com a noção de que nele está a transcrição de um "real", de um conhecimento a ser revelado. Assim como a linguagem, o currículo não é transparente, ele é um "local em que circulam signos produzidos em outros locais, mas também um local de produção de signos" (SILVA, 2001, p. 64). Em outras palavras, o conhecimento admitido como "real", inscrito no currículo, pode ser (re)definido fato que torna o currículo objeto de disputa, abrindo espaço para as relações de poder. Finalmente, é possível pensar o currículo como fetiche, considerando que alunos, professores, teóricos educacionais atribuem ao conhecimento que está ali "corporificado" (nos livros didáticos, guias, tópicos, temas, autores etc.) "poderes transcendentais”. O currículo é também fetiche, na visão do crítico educacional, por ser uma construção humana, social, cabendo a ele, portanto, desfetichizá-lo. Com isso, os críticos educacionais, segundo Silva, obliteram a idéia de que aquilo que vêem como fetiche possui uma história e é resultado de uma relação social. Sua proposta, então, é explorar a ambigüidade do fetiche, tratando-o não como algo negativo, indesejável, mas fruto de "uma contingência das nossas formas de conhecer e de representar" (p. 104). No campo educacional, explorar o currículo como fetiche não significa apenas vê-lo como conhecimento, como informação que ancora alunos e professores. Não está em questão, tampouco, expor, denunciar, revelar a fetichização do currículo, como faz a crítica educacional. Sua argumentação é no sentido de estabelecer uma nova relação "simpática" com o currículo. Essa relação implica aprender a conviver com ele, aceitando seu "hibridismo" entre o mundo das coisas e o mundo social. 
Se considerarmos resultados da pesquisa de Paiva, Frangella e Dias (2006) ${ }^{52}$, na qual investigam dissertações e teses, no período de 1996 a 2002, sobre a prática curricular e propostas curriculares oficiais e não oficiais, pensamos que a proposta de Silva (2001) carece, ainda, de constante discussão. De acordo com os autores dessa pesquisa, na grande maioria dos trabalhos, as políticas curriculares são vistas como produto exclusivamente da ação oficial, sendo a construção curricular entendida como "um processo de construção política exógeno e distanciado da atuação de professores e pesquisadores envolvidos nas questões de ensino" (p. 251). William Pinar, outro importante pesquisador do campo do currículo, afirma, em entrevista a Lopes e Macedo (2006, p. 17), que os estudos do currículo devem propiciar "conversa que inclui a memória, assim como um sentido de futuro (pelo menos um comprometimento com o futuro para o avanço nesse campo de estudo)". O entrevistado declara ainda que é necessário, para a teoria do currículo, num momento histórico em acelerada transformação, "descobrir e articular para si mesma e para outros" (p. 31), o significado das disciplinas escolares. Também sugere que a teoria psicanalítica tem muito a contribuir para a compreensão das complexas relações que envolvem subjetividade e aprendizagem, bem como ensino e currículo.

Mediante as discussões sobre currículo aqui expostas, parece-nos, neste ponto, inescapável postular uma questão que surge como emergente e, de nosso ponto de vista, bastante óbvia e pertinente: como contemplar as incertezas no âmbito curricular? Tal enfrentamento desponta como impreterível no ambiente da pós-modernidade, pois é nessa conjuntura que a ambivalência, a ambigüidade e a contingência mostram-se mais evidentes. Considerando que as propostas curriculares deslizam, revelando outros sentidos, que a preparação de alunos deve estar voltada para sua capacitação para buscar "novas respostas", sendo preciso desenvolver um "instinto" para avaliar o futuro, parece-nos imprescindível aprendermos a transitar de um terreno "fixo" para um movediço, sobretudo a movimentar-se nesse espaço de incerteza. Lembramos que, em momento anterior, mostramos como as incertezas permearam o discurso dos elaboradores das Diretrizes Curriculares (condições de produção).

\footnotetext{
${ }^{52}$ A pesquisa Estado da arte do currículo da educação básica, financiada pelo Inep/PNUD (Instituto Nacional de Estudos e Pesquisas Educacionais Anísio Teixeira / Programa das Nações Unidas para o Desenvolvimento) e realizada no âmbito da ANPEd (Associação Nacional de Pós-Graduação e Pesquisa em Educação), objetivou analisar o campo do currículo da escola básica tendo como foco as teses e dissertações produzidas pelos programas de pós-graduação em educação no país, no período de 1996 a 2002 (PAIVA; FRANGELLA; DIAS, 2006, p. 247).
} 
Teóricos curriculares sugerem a incorporação de áreas diversas nos debates, mas, como fazê-lo? Como não correr o risco de tornar-se apenas normativo? Como enfrentar o descompasso entre o aparente momento de certeza, de definição das escolhas curriculares e as contingências, as surpresas, as incertezas da sua não-realização? Caberia pensar se há maneiras de contemplar, nas opções acerca do currículo, no sentido stricto (preparo de um programa, escolha de um material, texto, livro, autor etc.), “cláusulas omissas" como em um documento de natureza jurídica? Não esperamos do currículo, no sentido lato do termo, com uma chancela governamental, que as incertezas (casos omissos) sejam resolvidas em determinado âmbito a ser designado (uma instituição, delegacia de ensino, coordenadoria, órgão supervisor etc.), no entanto, acreditamos que há maneiras de trazer para o plano educacional aquilo que possa se tornar imponderável: a dúvida, a incerteza, a contingência.

Com efeito, Morin (1999/2006), em Os sete saberes necessários à educação do futuro, dedica-se a pensar em como enfrentar a incerteza, a imprevisibilidade da história humana. ${ }^{53}$ Considerando a sociedade do conhecimento, na qual as mudanças apresentam valores ambivalentes, esse pensador francês advoga que a educação deve estar voltada para as incertezas ligadas ao conhecimento. O autor cunha a expressão "ecologia da ação" para indicar que toda ação escapa à vontade de seu autor ao entrar "no jogo das inter-retro-ações do meio em que intervém" (p. 88). É por meio da "ecologia da ação" que se explica o risco de fracasso, de desvio ou de perversão da intenção inicial de uma determinada ação. Sua proposta é a exploração do pensamento (ensinamento, poderíamos acrescentar) estratégico, no qual, ao invés da preparação de uma seqüência de ações (programa, diríamos), ou um plano de aula, por exemplo, o objetivo centrar-se-ia na elaboração de um cenário de ação. Tal cenário envolve as (in)certezas e as (im)probabilidades da ação planejada.

Evocamos a distinção entre "educar" e "treinar" proposta por Widdowson (1990, p. 62), pertinente para este momento da discussão. De acordo com o autor, o treinamento do professor envolve um processo de preparação para se atingir resultados, previamente, estabelecidos e conhecidos, ou seja, pouca ênfase é dada ao caráter inusitado do ensino, uma vez que o treinamento é pautado pela noção de previsibilidade. Por outro lado, a formação de professores (nossa tradução para teacher education), diz respeito ao preparo do professor frente à imprevisibilidade das situações educacionais, isto é, não se trata da aplicação de

\footnotetext{
${ }^{53}$ Em estudo anterior (1999/2000), o autor já havia trabalhado a mesma questão.
} 
técnicas padronizadas e prontas para serem mobilizadas em contextos educacionais. Isto significa que o professor deve ser capacitado para reformular idéias e modificar padrões estabelecidos diante das situações imprevisíveis de ensino. Desse modo, parece-nos impreterível a incorporação da incerteza, da dúvida, da contingência nas propostas curriculares, para que professores e futuros docentes possam ensinar, movimentando-se com mais autonomia em terrenos de incertezas.

Somos da opinião, conforme já expusemos, de que a ambivalência é constitutiva, assim como a contingência, a incerteza. Entendemos que o caminho proposto por Morin (2006) pode ser desafiador para educadores e alunos, entretanto, cabe-nos acrescentar que, antes de trabalharmos, ou pensarmos na criação de estratégias para enfrentar as incertezas da ação, é necessário pensar em mecanismos que possibilitem a compreensão da incerteza, da ambivalência, da contingência como fator desviante, inusitado, casual. Acreditamos que aqui reside desafio maior para educadores: despertar no aluno e no próprio professor a noção de que o imprevisível, o inesperado, o contingente sempre terá seu espaço cativo. Não se trata de uma aposta, um investimento na contingência, mas de pensar em meios de torná-la incorporada, integrada à aprendizagem. Não nos propomos no presente trabalho à exploração de tais meios, mas a investigar se e como essa questão aparece no discurso da formação.

Cabe lembrar, aqui, o conceito de "transposição didática", que pode ser um meio para se conseguir tal incorporação. O referido processo é empregado para designar a transformação do conhecimento científico em conhecimento escolar. ${ }^{54}$ Chevallard (1991), discutindo tal processo na matemática, advoga que para ensinar um determinado item do saber, ele deve passar por adaptações e/ou adequações a fim de torná-lo um objeto de ensino. Para o autor, então, a transposição didática é um processo criativo de transformação, primeiramente, de um objeto de saber em um objeto a ser ensinado e, subseqüentemente, em um objeto de ensino. Perrenoud (1997/1999), ao tratar do conceito de competência em educação, entendida por ele como "capacidade de agir eficazmente em um determinado tipo de situação, apoiada em conhecimentos, mas sem limitar-se a eles" (p. 7), defende a reconstrução da noção de transposição didática para a eficácia de uma abordagem por competências ${ }^{55}$. Para o autor, então, ela é a

\footnotetext{
${ }^{54}$ As DCF tratam de tal conceito em seu Art. $10^{\circ}$.

${ }^{55}$ Em trabalhos subseqüentes (1999/2000, 2002), o autor volta a discutir o desenvolvimento de competências para ensinar.
} 
sucessão de transformações que fazem passar da cultura vigente em uma sociedade (conhecimentos, práticas, valores etc.) ao que dela se conserva nos objetivos e programas da escola e, a seguir, ao que dela resta nos conteúdos efetivos do ensino e do trabalho escolar e, finalmente - no melhor dos casos -, ao que se constrói na mente de parte dos alunos (p. 73).

Desse modo, o autor defende a existência de um processo de investigação do docente a fim de vislumbrar com quais situações os alunos irão deparar-se na sociedade. Por isso sua defesa de que os programas escolares levem em consideração uma transposição didática baseada em uma "análise prospectiva e realista das situações de vida" (p. 74). Como a imprevisibilidade é condição básica da pós-modernidade, não basta fazer uso da transposição didática como mecanismo profilático de transformação da incerteza em conteúdo curricular. A questão nos parece mais complexa. Quando sugerimos a incorporação da incerteza no processo de formação de professores, não sugerimos apenas uma disposição curricular que contemple a incerteza, como forma de alerta sobre a imprevisibilidade da realidade escolar; nossa sugestão é no sentido de preparar o aluno para agir sobre ela. 
PARTE II

INVESTIGANDO O DISCURSO DA FORMAÇÃO DE PROFESSORES

Ser significa ser para o outro e, através dele, para si. O homem não tem um território interior soberano, está todo e sempre na fronteira, olhando para dentro de si ele olha o outro nos olhos ou com os olhos do outro.

[...] Eu não posso passar sem o outro, não posso me tornar eu mesmo sem o outro; eu devo encontrar a mim mesmo no outro, encontrar o outro em mim.

Mikhail Bakhtin. Estética da criação verbal. 


\title{
CAPÍTULO 4
}

\section{DIRETRIZES CURRICULARES}

\begin{abstract}
O que é afinal um sistema de ensino senão uma ritualização da palavra; senão uma qualificação e uma fixação dos papéis para os sujeitos que falam; senão a constituição de um grupo doutrinário ao menos difuso; senão uma distribuição e uma apropriação do discurso com seus poderes e seus saberes?

Michel Foucault. A ordem do discurso.
\end{abstract}

Nas reflexões que fizemos, no capítulo anterior, a partir de estudos resenhados sobre reformas curriculares, buscamos mostrar como vimos a disseminação de conceitos e políticas educacionais globais, esboçadas também no Brasil, como resultado de processos de aproximação de diferentes realidades ao redor do mundo. Esses processos que ocorrem sob a égide da globalização provocam o despertar de reflexões e preocupações que embora, na sua aparência, possam apresentar noções semelhantes, tendem a manifestar variantes de sentido, assumindo diferentes formas, de acordo com os contextos nos quais estão inseridos. Convém recordar que somos da opinião que esses conceitos mutantes e itinerantes devem ser cuidadosamente observados na realidade escolar, incluindo, aqui, reformas curriculares, projetos pedagógicos e cursos de formação de professores. Cabe ressaltar, ainda, que vimos nos apoiando em reflexões de Bauman (1999a, 2001, 2005) que postulam uma realidade pósmoderna fluida e líquida, assumindo, portanto, diferentes formas de modo incessante e rápido. Esse pensador chama a atenção, ainda, para características dessa nova realidade expressas no colapso da ilusão da totalidade, como também na desregulamentação e privatização de tarefas e deveres. Seguindo essa linha de pensamento, apontamos, no capítulo que antecedeu, como vimos a questão da transferência de obrigações para o nível individual. Além disso, discutimos acerca da determinação de perfis que as propostas curriculares apresentam, tendo como base essa realidade pós-moderna, líquida ou fluida. Questionamos, principalmente, as implicações dessa fluidez em cursos de formação de professores; para tanto, analisamos as condições de produção das Diretrizes Curriculares Nacionais, tomando contribuição de Popkewitz (2006) sobre a constituição de noções que se apresentam em pares (certezas/incertezas, esperanças/medos etc.). 
Por percebermos marcas de ambivalência nas Diretrizes Curriculares, isto é, as orientações apresentadas podem, naturalmente, ser desdobradas, desmembradas, ou apontar para rumos distintos, adotamos a "disjunção" como categoria de análise para abordarmos o corpus constituído por tais documentos. Então, neste momento do trabalho, apresentamos o terceiro foco de ocorrência da ambivalência. ${ }^{56}$ Vemos que a disjunção pode ser um modo de mostrar a ambivalência que, para nós, é noção presente em várias áreas do saber, em conceitos, nas relações humanas e para nosso propósito, nas discussões educacionais. Dessa forma, iniciamos a discussão do capítulo, apontando para essas marcas de ambivalência, para esse desdobrar de sentidos no discurso desses documentos. Este capítulo está subdividido em seções que levam em consideração momentos de irrupção dessa ambivalência que temos procurado demonstrar ao longo do estudo. Advogamos também que algumas sugestões apontadas nos documentos são reflexos de um contexto pós-moderno, no qual os conceitos viajam e se transmutam e as obrigações estão a cargo do indivíduo. Reiteramos que não vemos nesses documentos propostas definitivas para a elaboração curricular dos cursos de formação de professores/letras. Tampouco é nosso interesse propor alterações em seu texto. Nossa argumentação toma as Diretrizes Curriculares como exemplar de discurso, apontando para fragmentos discursivos que, por mostrarem-se ambivalentes, podem propiciar a continuidade de um determinado tipo de formação docente.

Quanto à formação de professores, a Lei 9.394 - Lei de Diretrizes e Bases da Educação, de 20 de dezembro de 1996, nos Art. 61 a $63,{ }^{57}$ contempla essa temática. No âmbito do Conselho Nacional de Educação - CNE, foram instituídas as Diretrizes Curriculares Nacionais para a Formação de Professores da Educação Básica, em nível superior, curso de licenciatura, de graduação plena (CONSELHO NACIONAL DE EDUCAÇÃO / CONSELHO PLENO, 2002a), e as Diretrizes Curriculares Nacionais dos cursos de Filosofia, História, Geografia, Serviço Social, Comunicação Social, Ciências Sociais, Letras, Biblioteconomia, Arquivologia e Museologia (CONSELHO NACIONAL DE EDUCAÇÃO / CÂMARA DE EDUCAÇÃO SUPERIOR, 2001). Essas diretrizes constituem-

\footnotetext{
${ }^{56}$ Lembramos que estamos investigando quatro diferentes dimensões (focos de ocorrência da ambivalência) ao longo do trabalho. Na primeira dimensão, apresentada no Capítulo 3 da Parte I (seção 3.2), mostramos, em nível mundial, os deslizamentos de sentidos de algumas políticas educacionais, de acordo com estudo de Lindblad e Popkewitz (2004a). Em seguida, na seção 3.4, voltamo-nos para a segunda dimensão ao tratarmos das condições de produção das Diretrizes Curriculares. Nesse momento, apontamos como vimos algumas formulações se constituírem em forma do par "hopelfear" (POPKEWITZ, 2006).

${ }^{57}$ Esses artigos remetem ao Decreto 3.276, de 06 de dezembro de 1999, que "dispõe sobre a formação em nível superior de professores para atuar na educação básica” (BRASIL, 1999).
} 
se em um conjunto de orientações norteadoras para a formulação do projeto pedagógico dos referidos cursos.

Lembramos análise de Severino (1986, p. 54), de que um dos planos do qual se pode encarar o discurso pedagógico é o plano do legal. Para ele, "o processo educacional desenvolve-se na sociedade supostamente de acordo com normas jurídicas, dispositivos legais elaborados e impostos pelo poder político-burocrático encarnado pelo Estado". Nesse mesmo artigo, ele destaca que:

[...] é possível apreender, através da política educacional em geral e da legislação educacional em particular, quais os elementos ideológicos preponderantes que o Estado, e através dele as classes dominantes de uma dada sociedade, quer veicular e inculcar ao todo da população (p. 56).

Dessa forma, neste capítulo, buscaremos identificar como as Diretrizes Curriculares Nacionais, enquanto “epistemologia social” (POPKEWITZ, 1991/1997, 1994), tentam moldar os cursos de formação de professores, os cursos de letras, como também os professoresformadores/professores e alunos. Para esse teórico da educação:

A epistemologia social fornece uma forma de analisar as regras e os padrões pelos quais o conhecimento sobre o mundo é formado e pelos quais as distinções, as categorizações que organizam as percepções, as formas de responder ao mundo e as concepções do "eu" são formadas através de nosso conhecimento sobre o mundo (1994, p. 197).

Para iniciarmos a discussão, é importante salientar que compartilhamos da visão do autor, ou seja, as Diretrizes Curriculares preconizam formas de educar e de ver o indivíduo, isto é, elas são resultados de uma construção social de sentidos. Evidenciamos que nossa abordagem das Diretrizes se fundamenta em uma perspectiva que entende a leitura como processo de produção de sentidos e não como texto acabado e de significação única. A recepção do leitor, caracterizado, nesse caso, pelos docentes de cursos de formação de professores/letras, sua vivência, associada ao seu conhecimento de mundo, irão atribuir sentidos ao texto, pois acreditamos que o "real" significado dessas Diretrizes estará nessa relação dialógica do texto com seu leitor. Ou seja, a construção do seu significado se completará a partir das impressões impostas ao texto por um outro (BAKHTIN, 2003). Apesar de não ser nosso interesse abordar a questão da recepção do leitor, pois tomaremos o texto das Diretrizes como exemplar de discurso, cumpre-nos chamar a atenção para esse fato, pois 
acreditando na complexidade dos princípios apresentados, somos da opinião de que toda reforma curricular deve ser amplamente discutida por todos que estão envolvidos no processo educacional, como já sinalizamos, anteriormente.

Conforme esclarecemos, as Diretrizes Curriculares para os cursos de letras destinamse a estabelecer normas para esses cursos de graduação, visando orientar a formulação do projeto pedagógico do referido curso. Para tanto, após a introdução, apresentando considerações acerca de suas características básicas e princípios norteadores, esse documento é formulado a partir dos tópicos a seguir:

a) o perfil dos formandos nas modalidades bacharelado e licenciatura;

b) as competências gerais e habilidades específicas a serem desenvolvidas durante o período de formação;

c) os conteúdos caracterizadores básicos e os conteúdos caracterizadores de formação profissional, inclusive os conteúdos definidos para a educação básica, no caso das licenciaturas;

d) a estruturação do curso;

e) as formas de avaliação.

Como, em alguns trechos desse documento, há sugestão para que se observe também as orientações constantes nas Diretrizes Curriculares Nacionais para a Formação de Professores da Educação Básica (DCF), elaboramos assim, breve explanação sobre tal documento. As orientações constantes nessa Resolução estão dispostas em forma de dezenove artigos, sendo alguns desses, desmembrados em itens, subitens e parágrafos. Tais artigos buscam contemplar a organização curricular de cada instituição, a concepção, o desenvolvimento e abrangência dos cursos de formação, a construção do projeto pedagógico e as competências profissionais, entre outros aspectos. Gostaríamos de salientar a característica eminentemente jurídica desse documento, quase contratual, que nos leva a compartilhar da visão de Grigoletto (2004), cuja análise sobre alguns textos que tratam do ensino de línguas estrangeiras modernas afirma que esse tipo de discurso, predominantemente impositivo, visa à uniformidade de método, conteúdos, procedimentos pedagógicos e administrativos de forma geral.

\subsection{Adequar-se para mudar ou mudar para adequar-se?}


Passemos à análise das Diretrizes, iniciando com itens propostos nas Diretrizes Curriculares para os cursos de Letras $(\mathrm{DCL})^{58}$. Em seu parágrafo inicial, identificamos o que poderíamos chamar de objetivo principal dessas DCL:

Esta proposta de Diretrizes Curriculares leva em consideração os desafios da educação superior diante das intensas transformações que têm ocorrido na sociedade contemporânea, no mercado de trabalho e nas condições de exercício profissional. Concebe-se a Universidade não apenas como produtora e detentora do conhecimento e do saber, mas, também, como instância voltada para atender às necessidades educativas e tecnológicas da sociedade. Ressalta-se, no entanto, que a Universidade não pode ser vista apenas como instância reflexa da sociedade e do mundo do trabalho. Ela deve ser um espaço de cultura e de imaginação criativa, capaz de intervir na sociedade, transformando-a em termos éticos. (CONSELHO NACIONAL DE EDUCAÇÃO / CÂMARA DE EDUCAÇÃO SUPERIOR - CNE/CES, 2001, p. $29^{59}$, grifos nossos).

O primeiro aspecto que gostaríamos de ressaltar é a preocupação com as "transformações na sociedade contemporânea e no mercado de trabalho". Logo em seguida, o esclarecimento sobre o papel da universidade de "atender às necessidades educativas e tecnológicas da sociedade". Percebemos, nessas formulações ${ }^{60}$, uma ênfase para que a universidade satisfaça à sociedade não apenas como instrumento de produção de conhecimento, mas que também volte seu olhar para as exigências do mercado de trabalho, sobretudo para as transformações tecnológicas ocorridas.

Sobre esse primeiro aspecto destacado, lembramos os trabalhos resenhados, no capítulo anterior, que vincularam as reformas educacionais às mudanças ocorridas na sociedade. Encontramos, no excerto acima, o mesmo discurso de que é preciso mudar também na educação, envolvendo aí, o papel da universidade, do seu professor e do seu aluno, em virtude de mudanças mais amplas que transformam o mercado de trabalho e o profissional.

58 As DCL foram estabelecidas pela Resolução CNE/CES 18, de 13 de março de 2002 (CONSELHO NACIONAL DE EDUCAÇÃO / CÂMARA DE EDUCAÇÃO SUPERIOR, 2002). Em seu Art. $1^{\circ}$ lê-se que "as Diretrizes Curriculares para os cursos de Letras, integrantes dos pareceres CNE/CES 492/2001 e 1363/2001, deverão orientar a formulação do projeto pedagógico do referido curso". Esclarecemos que no Parecer CNE/CES 492/2001 (CONSELHO NACIONAL DE EDUCAÇÃO / CÂMARA DE EDUCAÇÃO SUPERIOR, 2001) estão efetivamente descritas as Diretrizes Curriculares para os cursos de Letras. Desse modo, nossa análise toma como exemplar de discurso o referido documento.

59 A página mencionada nas citações do CNE/CES (2001) refere-se à paginação definida no documento consultado via internet (ver Referências Bibliográficas).

${ }^{60}$ Esse termo é mobilizado, no decorrer de nossa análise, seguindo definição de Courtine (1981). Para o autor, como as formulações são do nível do intradiscurso, isto é, fazem parte daquilo que se diz num dado momento sob determinadas condições, elas se esgotam no momento em que são ditas. 
Kaufman $^{61}$ postula que existe uma política invisível da escolarização que objetiva produzir indivíduos adaptáveis às necessidades do mercado. Giroux também nos alerta que:

[...] é imperativo examinar as forças ideológicas e materiais que têm contribuído para o que desejo chamar de proletarização do trabalho docente, isto é, a tendência de reduzir os professores ao status de técnicos especializados dentro da burocracia escolar, cuja função, então, torna-se administrar e implementar programas curriculares, mais do que desenvolver ou apropriar-se criticamente de currículos que satisfaçam objetivos pedagógicos específicos (1997, p. 158).

Por isso, um questionamento se impõe em relação ao sentido do termo "tecnologia". Para Popkewitz (1998), ele é usado para designar um plano de aula, por exemplo. Percebemos, então, como os deslizamentos de sentidos são passíveis de ocorrer, fato que nos reforça a entender a importância de discussões não apenas sobre esses documentos, mas sobre qualquer outro destinado a "organizar" uma realidade escolar. Podemos ampliar essa reflexão, ao considerarmos estudo de Coracini (2007), no qual ela analisa as relações conflituosas no imaginário de professores sobre o fenômeno da globalização e novas tecnologias (vídeo, televisão, internet, multimídia etc.). A autora pesquisa o modo como o marketing das novas tecnologias gera conflitos e tensões na constituição das subjetividades dos professores. ${ }^{62}$

Supondo que esse termo pode indicar qualquer técnica moderna e complexa, pensamos, por exemplo, no universo da informática. Entendemos que as novas tecnologias podem e devem ser incorporadas às práticas pedagógicas. Entretanto, acreditamos ser pertinente, primeiramente, pensarmos em formas de transformar os recursos oferecidos pelas tecnologias em maneiras de produzir conhecimento. Ou seja, o professor deve ser instigado a interferir criticamente nas informações coletadas via internet, por exemplo.

Concebe-se, comumente, o mundo "virtual" como fonte infinita de possibilidades com amplos instrumentos para auxiliar ou até mesmo "atrair" o aluno para a aula. Na verdade, é necessário que haja ponderação sobre o uso desses recursos para não se correr o risco de transformá-los em "regimes de verdade", segundo Foucault (1979/2003d). Ou seja, versões de "verdade" são elaboradas e estabelecidas que, envoltas por um caráter transcendente desses

${ }^{61}$ KAUFMAN, 1978 apud KINCHELOE, 1997, p. 60.

${ }^{62}$ A autora observa que o desenvolvimento tecnológico forma um imaginário que mitifica as novas tecnologias, transformando-as em recursos indispensáveis para o ensino. Daí surge o conflito dos professores; pois, desafiados diante desse "efeito de verdade" produzido, desejam dominar as novas tecnologias, mas, ao mesmo tempo, deparam-se com a falta de conhecimento diante do novo que fragiliza sua autoridade frente aos "saberes" veiculados por meio das novas tecnologias. 
recursos tecnológicos, tornam-se mecanismos de controle e de opressão. Por um lado, aqueles indivíduos desprovidos de tais recursos tornam-se "excluídos" de uma rede mais ampla de comunicação. Por outro lado, os detentores dos mais sofisticados recursos podem assumir uma posição que favorece o controle, o saber e, conseqüentemente, o poder.

Por meio dessa discussão, não queremos sugerir que a menção à tecnologia, nos documentos, é inadequada ou inconseqüente. Pelo contrário, o que advogamos é que há temas que demandam escrutínio constante. Desse modo, a questão é verificar se, e como, os debates acerca do tema "novas tecnologias" estão inseridos no momento da elaboração do currículo, das escolhas das disciplinas, enfim, na extremidade em que elas produzirão seus efeitos: a sala de aula. A esse respeito, destacamos asserção de Macedo (1997, p. 39) sobre "os mirabolantes projetos oficias, que apresentam a tecnologia como grande redentora dos problemas da área" educacional. Lembramos, também, estudo sobre o impacto das tecnologias da informação e da comunicação (TIC), em contextos educacionais, de Barreto (2005), argumentando que há uma "fetichização" de tais recursos, promovida pelo mercado, como se representassem "solução mágica" para problemas educacionais. A autora investiga resultados de pesquisas desenvolvidas em escolas na cidade do Rio de Janeiro sobre as TIC e aponta práticas que, revestidas de um caráter inovador (por exemplo, utilização do processador de texto Word), revelavam "prática velha e sem sentido" (ditado de palavras). A pesquisadora defende a necessidade de se inventar e socializar táticas que viabilizem o trabalho com as TIC com a intenção de "agregar novos sentidos à formação e ao trabalho docente" (p. 156).

Destacaremos, ao longo da análise, trechos que identificamos como, eminentemente, de efeito retórico no discurso, como vimos acima acerca do termo tecnologia. Mas, voltemos à questão do papel da universidade. $\mathrm{O}$ segundo ponto que destacamos trata da criação de um duplo que formulamos como produzir/sofrer reflexo da sociedade. Ou seja, há o investimento na universidade para ela ser capaz de intervir, transformar, enfim, ser ativa, mas, ao mesmo tempo, há a instauração de um par oposto que descreve a passividade, ou a aceitação da universidade como apenas um reflexo da sociedade. Na verdade, o que acenamos, nesse momento, é um desdobramento do que chamamos de bifurcação de sentidos ou criação de pares/duplos. A formulação de que a "Universidade não pode ser vista apenas como reflexo da sociedade e do mundo, mas sim como espaço de cultura, imaginação criativa, com capacidade de intervenção e transformação na sociedade" coloca em cena dois elementos da pós-modernidade. Primeiramente, a (re)distribuição de deveres: a universidade "deve ser 
capaz de...”, ou seja, ela passa a ter essa atribuição. Há, desse modo, uma transferência de obrigações, pois discursivamente não se esboça a quem essa tarefa era atribuída. Entendemos que essa transferência de obrigações pode ocorrer em diversos níveis, não apenas partindo do Estado para o indivíduo, pois da ótica da fluidez, há um deslizamento constante inclusive sobre a desregulamentação de obrigações. O fato que nos interessa é observar como os deslizamentos de sentidos ocorrem e as implicações daí advindas. Apple (1994, p. 63), por exemplo, nos alerta que as diretrizes e metas curriculares objetivam responsabilizar as escolas "pelo sucesso ou fracasso de seus alunos". Desse modo, conforme defendemos anteriormente, nossa crítica aos documentos é no sentido de provocar reflexões acerca das possíveis representações discursivas, a fim de entender como elas funcionam e, principalmente, agir sobre elas.

De acordo com Kincheloe (1997, p. 173), ao incorporar modelos à sua prática, os professores "permitem que o poder molde suas vidas profissionais". Na verdade, Foucault (2003c e 1975/2003b) argumenta que o poder também produz saber, ele não é apenas um dispositivo que serve para censurar ou oprimir. Portanto, entendemos que "para atender às necessidades educativas e tecnológicas da sociedade", os professores devem estar atentos para que isso não os torne dependentes ou seguidores de uma nova rede global de informações, acreditando que as novas tecnologias garantem um "ensino melhor".

Mencionando Lyotard, Peters (1994) nos diz que a noção de "cultura de empresa" pode ser a criação de uma metanarrativa. Ele argumenta que:

\footnotetext{
Essa nova metanarrativa está baseada numa nova visão do futuro. A linguagem usada para sustentar essa visão é uma linguagem de 'excelência', 'inovação, melhoria e modernização', 'obter mais com menos', 'alfabetização tecnológica', 'revolução na informação e nas telecomunicações', 'marketing e gerência internacionais', 'treinamento de habilidades', 'desempenho' e 'empresa' (p. 222).
}

Isto posto, desejamos enfatizar, portanto, que vemos a possibilidade de preparar um futuro professor, utilizando avançados recursos tecnológicos para "satisfazer" o mercado de trabalho. Contudo, parece-nos indispensável pensar sobre a maneira como os recursos tecnológicos são utilizados no cotidiano escolar. É inevitável considerar aqui, novamente, reflexão de Foucault sobre as ramificações do poder no momento que se torna capilar (1979/2003e). É na sua extremidade (espaço sala de aula) que a inserção de técnicas e 
instrumentos (computadores, referências ao mundo virtual, consultas a internet) pode possibilitar a criação de uma soberania do saber e, portanto, de dominação. Dependendo do modo como alunos, professores, instituições escolares passem a utilizar-se de tais recursos tecnológicos, atribuindo-lhes característica de fonte inesgotável de saber e possibilidades, assumindo-os como discursos de verdade, esses recursos podem tornar-se mecanismos produtores de discriminação na escola e na sociedade como um todo.

Gostaríamos de destacar outro momento, que identificamos como, eminentemente, de efeito retórico no discurso. A respeito do objetivo principal dessas DCL, chamamos a atenção para um fragmento que parece ficar à margem das discussões: "ela [universidade] deve ser um espaço de cultura e de imaginação criativa, capaz de intervir na sociedade, transformando-a em termos éticos". Pensamos que tal atribuição de tarefa à universidade demanda, entre outros aspectos, tempo, debates e investigação sobre o conceito de ética, de como ele é explorado nas instituições de ensino, quem está autorizado a discutir tal tema nas universidades. Concluímos que a forma como essa questão é proposta nos documentos pode fazer com que a noção de ética incorra em um espaço vazio, que não cala, fato que, no nosso ponto de vista, imprime no discurso um efeito de distanciamento, de inoperância das propostas.

\subsection{A "flexibilidade" como palavra de ordem}

Após refletirmos sobre os objetivos dessas Diretrizes, lançamos também um olhar para os princípios norteadores presentes nas DCL:

Os princípios que norteiam esta proposta de Diretrizes Curriculares são a flexibilidade na organização do curso de Letras e a consciência da diversidade / heterogeneidade do conhecimento do aluno, tanto no que se refere à sua formação anterior, quanto aos interesses e expectativas em relação ao curso a ao futuro exercício da profissão. A flexibilização curricular, para responder às novas demandas sociais a aos princípios expostos, é entendida como a possibilidade de:

- eliminar a rigidez estrutural do curso;

- imprimir ritmo e duração ao curso, nos limites adiante estabelecidos;

- utilizar, de modo mais eficiente, os recursos de formação já existentes nas instituições de ensino superior. (CONSELHO NACIONAL DE EDUCAÇÃO / CÂMARA DE EDUCAÇÃO SUPERIOR, 2001, p. 29, grifos nossos).

Nesse excerto, observamos a materialização de palavras de ordem como resultado da disseminação de conceitos que a realidade pós-moderna faz propagar. Remetemos o leitor ao 
estudo de Maguire (2004), no qual a autora analisa processos de "modernização" no contexto escolar inglês e suas implicações para os professores. Nos documentos analisados, sugere-se que o professor contemporâneo seja flexível. Compreendemos que, nas DCL, a flexibilidade é outorgada aos profissionais envolvidos com a questão curricular, que devem "imprimir ritmo", "utilizar recursos" e "eliminar rigidez”, ou seja, ela está presente, é parte inerente, pois dito desse modo, ela é suposta como existente. É interessante notar como essa característica de flexibilidade apresenta simultaneamente seu duplo, sua outra face, criando um par que designaremos como flexibilidade/rigidez. Ou seja, não há como dissociar essas noções, pois essa flexibilidade irá, fatalmente, apresentar limites, ou ainda, a flexibilização poderá vir a ser negada ou rejeitada, o que levará ao aparecimento do seu duplo: a rigidez. Notemos ainda como a incisa "de modo mais eficiente" ajuda a criar esse efeito binário. Depreende-se que os recursos de formação existentes nas instituições de ensino superior não são ou podem não ser utilizados de modo eficiente, que vise à flexibilização, portanto.

Os termos "diversidade" e "heterogeneidade", apontados no excerto anterior, parecem pertinentes para uma discussão que leve em consideração os preceitos de uma educação pósmoderna, já mencionados, quais sejam: a desestabilização das verdades únicas, o descentramento e reformulação de conceitos e perspectivas etc. Antes, porém, para o propósito de nossa reflexão, acatamos contribuições dos estudos lingüísticos de AuthierRevuz (1998/2001, 2004), para quem, em todo discurso, há inscrições de marcas lingüísticas de diversos enunciadores, isto é, dizeres formulados de diferentes pontos de vista. Segundo a autora, a heterogeneidade é constitutiva do sujeito, do discurso e do dizer. Partindo de tal premissa, cabe questionarmos, em nossa análise, como o professor irá desenvolver práticas que dêem conta dessa perspectiva. Para Silva (2003, p. 76), numa perspectiva dos estudos culturais, tanto "a identidade como a diferença têm que ser ativamente produzidas [...] Somos nós que as fabricamos, no contexto de relações culturais e sociais". Nossa preocupação, portanto, reside no fato de que, se esse docente que prepara futuros professores para o exercício do magistério não estiver alerta sobre a complexidade das questões que envolvem a diversidade (raça, classe sócio-econômica, origem, variações lingüísticas etc.) e a heterogeneidade (formações discursivas, perspectivas enunciativas, efeitos de sentido, etc.), levando em conta uma perspectiva lingüística-discursiva, seu trabalho didático-pedagógico poderá voltar-se apenas para maneiras pré-estabelecidas de buscar e manter homogeneidades em sua sala de aula. 
Lembramos reflexões de McLaren (1997), prefaciando o trabalho de Giroux, das quais, por considerarmos relevantes, citaremos algumas que julgamos endossar nossas preocupações com o tema da diversidade:

Como podem os problemas relacionados com classe, raça, gênero e poder serem traduzidos em questões de qualidade e excelência educacional? De que maneira podemos nos reposicionar enquanto educadores contra a cultura dominante a fim de reconstituir nossas próprias identidades e experiências e aquelas de nossos estudantes? Como é possível reconhecer a diferença e as múltiplas formas de identidade e ainda assim abordar as questões de vontade e luta política? Que diversidade silenciamos em nome de uma pedagogia libertadora? (MCLAREN, 1997, p. xiii).

Acreditamos que essa "consciência" (da diversidade/heterogeneidade) almejada pelas Diretrizes requer do docente um maior engajamento para desvendar, em sua prática, formas autoritárias e não críticas de ensinar, camufladas por uma atitude criativa e libertadora. Esse engajamento deve traduzir-se em pesquisa, em utilização de recursos semióticos, etnográficos, conforme aponta Kincheloe (1997). Na verdade, esses são alguns caminhos, pois não há garantias de que isso possa despertar no educador uma percepção mais acurada das particularidades de cada aprendiz.

Faz-se necessário olharmos também para os princípios norteadores das DCF, nos quais há destaque para a formação para a atividade docente com o objetivo de preparar para:

I. o ensino visando à aprendizagem do aluno;

II. o acolhimento e o trato da diversidade;

III. o exercício de atividades de enriquecimento cultural;

IV. o aprimoramento em práticas investigativas;

V. a elaboração e a execução de projetos de desenvolvimento dos conteúdos curriculares;

VI. o uso de tecnologias da informação e da comunicação e de metodologias, estratégias e materiais de apoio inovadores;

VII. o desenvolvimento de hábitos de colaboração e de trabalho em equipe. (CONSELHO NACIONAL DE EDUCAÇÃO / CONSELHO PLENO, 2002a, Art. $2^{\circ}$, grifos nossos).

Primeiramente, essa seqüência de substantivos nos traz à mente o trabalho de Grigoletto (2002). Em sua análise sobre os sentidos da nomeação the transfer of power sobre o processo de concessão da independência da Índia, essa autora menciona um ensaio de 
Barthes, no qual ele constata que os substantivos identificam noções genéricas. ${ }^{63}$ Segundo a pesquisadora, esse teórico diz ainda que o uso do artigo definido com substantivos confere o caráter de postulados que não podem ser contestados. Vemos que essa análise contribui com o nosso trabalho no sentido de mostrar como esses enunciados ${ }^{64}$ colaboram com a criação de um discurso difuso, reforçando, dessa forma, algumas postulações anteriores sobre a possibilidade de se manter o status quo por meio de leis que, ao não precisar posturas e condutas, deixarão o professor refém de práticas já cristalizadas. Lembramos que essas formulações fundamentam não apenas as DCL, mas também as Diretrizes de diversos cursos (filosofia, história, geografia, serviço social etc.). Dessa forma, caberia problematizar também como cada um desses cursos daria conta de aspectos como "o acolhimento e o trato da diversidade", "o uso de tecnologias da informação", entre outros, a partir de fragmentos tão "abertos" e genéricos.

O segundo aspecto que observamos nesse excerto é a presença de algumas palavras de ordem ou expressões que passaram a fazer parte de um discurso, que vimos analisando como reflexo de uma condição pós-moderna: "diversidade”, "práticas investigativas”, "tecnologias da informação", "materiais de apoio inovadores", "hábitos de colaboração e de trabalho em equipe”. Lembramos alguns exemplos já mencionados (Inglaterra: atuação em equipe; França: integração social; Brasil: consideração das diferenças, multiculturalismo, inovação etc.). Entendemos que essas expressões no texto das DCF foram contempladas ou metamorfoseadas nas DCL com o uso do termo "flexibilidade", se a tomarmos com o significado de ligeireza de movimentos ou ainda "aptidão do espírito para se aplicar a diversas ocupações e estudos" (HOUAISS, 2001). Assim, o termo "flexibilidade" contempla todas as outras qualidades sugeridas (capacidade de aceitar diferenças, de ser investigativo, inovador, cooperativo etc.). Enfim, notamos que os conceitos podem viajar por várias partes do mundo, como já dissemos, como também migrar e se transformar em níveis mais próximos, por exemplo, das DCF para as DCL. Não queremos com isso mostrar-nos contrários ou rejeitar noções que se tornam disseminadas. A questão que colocamos aqui é a de investigar a maneira pela qual essas noções aparecem como fruto de um discurso que pode ser identificado como pós-moderno e,

\footnotetext{
${ }^{63}$ Barthes, em seu ensaio intitulado "Gramática africana", analisa a linguagem do governo colonialista francês sobre a África. O autor constata o predomínio de substantivos que identificam noções genéricas como "humanidade", "missão", "cooperação" etc., no vocabulário do colonizador ao descrever suas atividades realizadas no continente africano (BARTHES, 1970 apud GRIGOLETTO, 2002, p. 128).

${ }^{64}$ Mobilizamos o termo, tendo em vista contribuição de Courtine (1981), a partir da teorização de Foucault (1969/2007). Conforme nos diz o autor, os enunciados encontram-se no interdiscurso, que é a instância de constituição dos sentidos, por estar ali todo o conjunto de formulações ditas e esquecidas. Por isso, diferentemente das formulações que se esgotam ao serem ditas, os enunciados se repetem.
} 
principalmente, como elas se tornam fluidas, mutantes, tendo, assim, seus sentidos desdobrados. $^{65}$

\subsection{Entre o necessário e o contingente}

Quanto ao perfil dos formandos, julgamos ser importante refletir um pouco mais sobre “as relações com o outro", mencionado nesse trecho das DCL que transcrevemos:

O objetivo do Curso de Letras é formar profissionais interculturalmente competentes, capazes de lidar, de forma crítica, com as linguagens, especialmente a verbal, nos contextos oral e escrito, e conscientes de sua inserção na sociedade e das relações com o outro. (CONSELHO NACIONAL DE EDUCAÇÃO / CÂMARA DE EDUCAÇÃO SUPERIOR, 2001, p. 30, grifos nossos).

Como encarar esse "outro" sem incorrer nos conceitos tão amplamente difundidos sobre respeito ao outro, direito do outro, etc.? As considerações de Bakhtin (2003) ampliam essa concepção de que o "outro" também nos compõe. A questão que se coloca é: quais as representações que fazemos desse "outro"? Ou ainda, quais as representações que professores/professores-formadores fazem desse “outro"? Skliar (2003, p. 71), partindo das reflexões advindas dos estudos culturais, argumenta que existe uma "regulação e um controle que define para onde olhar, como olhamos quem somos nós e quem são os outros e, finalmente, como o nosso olhar acaba por sentenciar como somos nós e como são os outros". Argumenta, também, que há uma banalização do emprego do termo "o outro" em contextos educacionais (p. 29). Consideramos, então, que essas reflexões, associadas à falta de compreensão das relações dialógicas imbricadas com o seu uso, poderão perpetuar visões distorcidas e tendenciosas que sufocarão as diferenças inerentes a cada indivíduo, ao espaço sala de aula e à escola de uma maneira mais ampla.

Tomemos outro excerto das DCL, ainda abordando a questão do perfil do profissional formado pelo curso de letras:

\footnotetext{
${ }^{65} \mathrm{Na}$ interpretação de Demo (1999, p. 25-26), sobre a LDB n ${ }^{\circ}$ 9394, de 20/12/1996, apesar de a noção de "flexibilidade" ser apropriada ao contexto educacional, alguns riscos (deslizamentos, diríamos) devem ser observados. Por exemplo: "a flexibilidade pode ser confundida com o abuso do direito de interpretar", como também "pode ser confundida com certo "vale-tudo"". De forma mais pontual, o autor nos alerta que a flexibilidade "pode principalmente ser mal utilizada pelas autoridades locais, sob todos os ângulos, desde nivelar tudo por baixo, alegando falta de condições financeiras sobretudo, encobrir a politicagem, até contentar-se com aprendizagem nenhuma; pode servir, nesse contexto, para maltratar ainda mais os docentes e os alunos, sempre sob a escusa da falta de recursos".
} 
Independentemente da modalidade escolhida, o profissional em Letras deve ter domínio do uso da língua ou das línguas que sejam objeto de seus estudos, em termos de sua estrutura, funcionamento e manifestações culturais, além de ter consciência das variedades lingüísticas e culturais. Deve ser capaz de refletir teoricamente sobre a linguagem, de fazer uso de novas tecnologias e de compreender sua formação profissional como processo contínuo, autônomo e permanente. A pesquisa e a extensão, além do ensino, devem articular-se neste processo. O profissional deve, ainda, ter capacidade de reflexão crítica sobre temas e questões relativas aos conhecimentos lingüísticos e literários. (CONSELHO NACIONAL DE EDUCAÇÃO / CÂMARA DE EDUCAÇÃO SUPERIOR, 2001, p. 30, grifos nossos).

Encontramos, nesse excerto, qualidades que são esperadas do profissional formado pelo curso de letras. Primeiramente, destacamos o efeito da busca pela completude, expresso por meio dos vocábulos "domínio" da língua-alvo (sobre estrutura, funcionamento e manifestações culturais) e "consciência" (sobre variedades lingüísticas e culturais). Percebemos que esse desejo de completude, ou seja, conhecer todos os aspectos relacionados à língua-alvo e ter consciência sobre suas variedades implicam uma busca constante. $\mathrm{O}$ que significa para um aluno ter domínio sobre as manifestações culturais, nas quais essa línguaalvo está envolvida? Considerando a rapidez com que as informações circulam e, conseqüentemente, a fluidez dos conceitos e idéias por elas veiculadas, poderíamos ainda questionar em qual momento é possível afirmar que se tem o domínio da estrutura e do funcionamento dessa língua, por exemplo. Some-se a isso, a rapidez com que novas palavras são criadas e/ou transformadas em virtude de mudanças sociais, políticas e econômicas.

De modo similar, a palavra "consciência" também sugere totalidade de conhecimento sobre as variedades lingüísticas e culturais, implicando uma busca incessante. Tal efeito é reforçado, ao se propor que o "profissional em Letras" seja capaz de compreender sua formação por meio de um processo "contínuo, autônomo e permanente". Cria-se, dessa forma, uma proposição para que a formação nunca termine, esboçando o perfil de um aprendiz que pode ser caracterizado como sendo um lifelong learner, ou seja, um aprendiz para toda a vida. Há, sobretudo, um compartilhamento dessa formação, podemos dizer até que há uma transferência de dever do professor/professor-formador para o aluno, inculcada por meio da qualidade "autonomia". Pensamos que essa "compreensão do processo de formação" funciona como o estabelecimento de um compromisso entre aluno e professor/professor-formador, no qual esse se responsabiliza pela assimilação, o entendimento, de que o aluno tome para si sua formação. Esse aluno, portanto, deve saber se autogovernar, deve ter liberdade para 
administrar, selecionar, produzir conhecimentos para sua formação. Vemos essa "transferência de autonomia" para o futuro profissional como fruto do que vimos nos empenhando para esclarecer a respeito da desregulamentação de deveres que a pósmodernidade imprime. Julgamos pertinente inserir qualidades como autonomia e interesse pelo aperfeiçoamento contínuo na formação de professores, mas acreditamos que essa perspectiva aberta merece escrutínio a fim de termos um painel de como essa relação pode acontecer na vida do curso. A pergunta que se impõe, então, é saber como ocorre esse compartilhamento da responsabilidade pela formação. Salientamos ainda o fato de que, além de possuir domínio e consciência sobre a língua-alvo, esse profissional deve ter reflexão crítica, ser capaz de refletir teoricamente sobre a linguagem e fazer uso de novas tecnologias. Apontamos, novamente, que essas são manifestações dos discursos recorrentes sobre reformas curriculares, conforme mostramos em nossa análise no capítulo anterior sobre o documento White Paper on Education and Training, por exemplo, bem como no estudo argentino, no qual a palavra de ordem apontada foi "autonomia" (DUSSEL, 2004).

Não estamos discutindo a validade dessas noções e qualidades para a educação ou para educadores e aprendizes. Nosso propósito, vale reiterar, é pensar sobre os efeitos de sentido desses conceitos inseridos na realidade escolar e, principalmente, refletir sobre as possíveis decorrências que essas noções podem promover. Partindo da questão do perfil do formando, que foi acima discutido, pensamos que é possível ocorrer, durante o processo de formação, a construção de um duplo que classificamos como necessário/contingente. Como esse perfil deve apresentar as qualidades mencionadas (domínio, consciência etc.), é preciso indagar sobre os mecanismos a serem colocados em uso na determinação ou escolha dos conteúdos formadores que preparem o futuro profissional para conseguir essas qualidades. Como se dão no interior de um curso de formação de professores as discussões e escolhas das teorias sobre a linguagem, por exemplo? Ou ainda, como a pesquisa e a extensão serão articuladas para tornar o futuro professor autônomo? Como ocorre a inclusão de novas tecnologias que visem formar um profissional crítico? Enfim, essa seqüência de questões elencadas nos faz pensar que ao tentar determinar os conteúdos que possam ser, ou possam desenvolver "domínio", "consciência", "reflexão crítica" etc., fatalmente, haverá um deslizar de objetivos que irão oscilar entre conceitos necessários ou contingentes. Podemos supor que algumas perguntas possíveis sejam: qual a necessidade de incluir determinado conteúdo se ele será apresentado futuramente por outro professor, ou de outra forma? Qual a necessidade de discutir certos conceitos, se o aluno não pretende seguir determinado rumo em seus estudos, ou se essas 
discussões poderão ocorrer ainda em momento posterior, em virtude da complexidade de uma abordagem teórica, por exemplo? Poderíamos ainda continuar com outras teorizações, porém o que desejamos enfatizar é a constituição dessa oscilação disjuntiva ao se pensar sobre as escolhas curriculares. Em ambas as possibilidades essa oscilação entre o par necessário/contingente irá se configurar. Por um lado, se a busca pela completude for assumida como possível, a escolha entre conhecimentos necessários para atingi-la determinará aqueles que são contingentes. Por outro lado, se a totalidade não for considerada como meta factível, muitos desses conhecimentos serão contingentes, fazendo com que as escolhas incidam sobre alguns "necessários” apenas.

Voltaremos ainda aos dois excertos anteriores, mas identifiquemos, nos trechos que se seguem, as determinações acerca das competências e habilidades dos formandos:

[...] o curso de Letras deve contribuir para o desenvolvimento das seguintes competências a habilidades:

- domínio do uso da língua portuguesa ou de uma língua estrangeira, nas suas manifestações oral e escrita, em termos de recepção e produção de textos;

- reflexão analítica e crítica sobre a linguagem como fenômeno psicológico, educacional, social, histórico, cultural, político e ideológico;

- visão crítica das perspectivas teóricas adotadas nas investigações lingüísticas e literárias, que fundamentam sua formação profisssional;

- preparação profissional atualizada, de acordo com a dinâmica do mercado de trabalho;

- percepção de diferentes contextos interculturais;

- utilização dos recursos da informática;

- domínio dos conteúdos básicos que são objeto dos processos de ensino e aprendizagem no ensino fundamental e médio;

- domínio dos métodos e técnicas pedagógicas que permitam a transposição dos conhecimentos para os diferentes níveis de ensino. (CONSELHO NACIONAL DE EDUCAÇÃO / CÂMARA DE EDUCAÇÃO SUPERIOR, 2001, p. 30, grifos nossos).

Chamamos a atenção para a opacidade das características desejadas: "interculturalmente competentes", "conscientes de sua inserção na sociedade e das relações com o outro", apontados no primeiro excerto da seção, e "percepção de diferentes contextos interculturais", no excerto acima. Reconhecemos que competência, consciência e percepção são noções complexas que merecem apuro de detalhes, no entanto, não vemos nas DCL discussão no sentido de mostrar algumas dimensões desses conceitos. Não é nosso objetivo, tampouco, analisá-los neste trabalho, entretanto, salientamos o fato de a densidade de tais conceitos fazer com que a formulação "preparação profissional atualizada, de acordo com a 
dinâmica do mercado de trabalho" torne-se mais evidente, realçada, pois, ao contrário dos conceitos anteriores, nesse, a "preparação" é orientada, detalhada. Notemos como esse efeito é produzido pelo marcador discursivo "de acordo com", iniciando a incisa que se segue.

Destacamos, ainda, que as formulações acima "preparação profisssional atualizada, de acordo com a dinâmica do mercado de trabalho" e "utilização dos recursos da informática" são noções que remetem a conceitos elaborados também em nível mundial. ${ }^{66}$ Entretanto, conforme demonstramos, no capítulo anterior, tais conceitos passam por uma alquimia local que os fazem adquirir novas "roupagens". Logo, cabe-nos observar os deslizamentos, as "roupagens", as transformações deles inseridos no âmbito que aqui investigamos. Além dos oito quesitos listados no excerto anterior, há, ainda, em outro momento do texto, formulação sugerindo que o formando "deverá ter, também, a capacidade de resolver problemas, tomar decisões, trabalhar em equipe e comunicar-se dentro da multidisciplinaridade dos diversos saberes que compõem a formação universitária em Letras" (CONSELHO NACIONAL DE EDUCAÇÃO / CÂMARA DE EDUCAÇÃO SUPERIOR, 2001, p. 30, grifos nossos). A ênfase para "resolver problemas", "tomar decisões" e "trabalhar em equipe" nos faz lembrar, novamente, da análise de Giroux (1997) sobre a proletarização do trabalho docente. Podemos ver esses conceitos aplicados a uma perspectiva educacional, no entanto, nosso conhecimento de mundo nos informa que essas são palavras-chave, conceitos amplamente difundidos no mercado de trabalho contemporâneo. Conforme Orlandi (1988/2001, p. 53), “o discurso é uma dispersão de textos". Isso nos faz perceber que os sintagmas: "resolver problemas", "tomar decisões" e "trabalhar em equipe" são materializações lingüísticas que nos remetem a um discurso empresarial. É válido, sobretudo, observar que essas formas vêm expressas com emprego de verbos - que transmitem dinamismo e diligência - diferentemente das formulações anteriores expressas com substantivos, que, conforme já mencionamos, ajudam a criar uma certa vaguidade no discurso. Assim sendo, nesse ponto da reflexão, podemos concluir que as adaptações ou as transformações de sentido das palavras de ordem, no contexto analisado, apontam para um nicho predominantemente mercadológico. Cabe relembrar, aqui, análise de Moreira e Silva (1994), exposta no capítulo anterior, sobre as novas tecnologias e a informática. A preocupação dos autores, quando o ensaio foi produzido, residia no fato de que a ausência de uma "teorização curricular crítica" sobre tais temas poderia deixar a educação e o currículo à mercê de objetivos mercadológicos.

66 Como exemplos ilustrativos, lembramos, entre outras, as formulações no documento White Paper on Education and Training, apontadas no capítulo anterior. 
Nosso entendimento sobre essas exigências do perfil do profissional de letras nos mostra um painel dividido entre noções, expectativas, conceitos complexos e de vastas dimensões de um lado, e de outro, noções mais próximas do aprendiz, mais pragmáticas, mais direcionadas. Notemos como "fazer uso de novas tecnologias" e "utilização dos recursos da informática" são noções mais específicas, mais procedimentais. Vemos, dessa forma, a construção de uma postura disjuntiva: de um lado, temos requisitos mais precisos e, de outro, noções mais gerais. Podemos ainda enfatizar que a expressão "fazer uso de novas tecnologias" causa um efeito paradoxal, pois "fazer uso de" parece iniciar a descrição de um procedimento mais específico, no entanto, a inclusão de "novas tecnologias", conforme já apontamos, é também um conceito amplo, ocorrência que faz a expressão ter efeito de oxímoro. Na nossa interpretação, isso parece figurar um deslizamento de sentidos, ou uma bifurcação, conforme já vimos empregando. Mas, voltemos, por ora, nossa atenção para outros aspectos apresentados nas DCL.

\subsection{Entre a teoria e a prática}

Com relação aos conteúdos curriculares, tomemos o excerto seguinte:

Considerando os diversos profissionais que o curso de Letras pode formar, os conteúdos caracterizadores básicos devem estar ligados à área dos Estudos Lingüísticos e Literários, contemplando o desenvolvimento de competências a habilidades específicas. Os estudos lingüísticos e literários devem fundar-se na percepção da língua e da literatura como prática social e como forma mais elaborada das manifestações culturais. Devem articular a reflexão teórico-crítica com os domínios da prática - essenciais aos profissionais de Letras, de modo a dar prioridade à abordagem intercultural, que concebe a diferença como valor antropológico e como forma de desenvolver o espírito crítico frente à realidade. (CONSELHO NACIONAL DE EDUCAÇÃO / CÂMARA DE EDUCAÇÃO SUPERIOR, 2001, p. 31, grifos nossos).

Inicialmente, chamamos a atenção para a formulação: "abordagem intercultural que concebe a diferença como valor antropológico e como forma de desenvolver o espírito crítico frente à realidade". É mister salientar que não identificamos, nas DCL e nas DCF, uma ênfase para a construção de currículos contextualizados. Ou seja, não há referências à importância do conhecimento local, situacional. Acreditamos que caberia mencionar no texto, de maneira explícita, que os projetos curriculares deveriam incluir o conhecimento trazido por diversas representações encontradas na sociedade (grupos de diferentes raças, crenças, origens etc.), na 
tentativa de desencorajar qualquer forma de preconceito. No entanto, vemos que, no discurso, a formulação "priorização da abordagem intercultural" parece prescindir de comentários. Parece-nos imprescindível relembrar contribuições de Giroux:

O conhecimento no modelo curricular dominante é tratado basicamente como um domínio dos fatos objetivos. Isto é, o conhecimento parece objetivo no sentido de ser externo ao indivíduo e de ser imposto ao mesmo. Como algo externo, o conhecimento é divorciado do significado humano e da troca intersubjetiva.

Uma vez perdida a dimensão subjetiva do saber, o propósito do conhecimento torna-se a acumulação e a categorização. Perguntas do tipo "Por que este conhecimento?" são substituídas por perguntas técnicas como "Qual é a melhor maneira de se aprender este dado corpo de conhecimento? (GIROUX, 1997, p. 45-46).

Dizer-se inclusivo e consciente das diferenças não é suficiente para possibilitar uma conduta pedagógica que realmente dê conta de verdades locais e contextualizadas. Sobre essa questão, evocamos Orlandi (1997, p. 12) e sua reflexão sobre o silenciamento. Segundo essa autora, "há um sentido no silêncio", isto é, essa ausência também significa algo. Acreditamos que apenas o emprego dos termos "diversidade", "heterogeneidade", mencionados no texto e analisados na seção 4.2 , não reproduzem a complexidade inerente a esses conceitos.

Nessa mesma linha de reflexão, outro aspecto que é "posto em silêncio" é a questão do material didático ${ }^{67}$. Vale ressaltar que não esperamos uma lista de opções ou guias, entretanto, a ausência de um apelo para que se considerem no currículo formas locais de conhecimento, conforme apontamos, poderá deixar os elaboradores do currículo "oficial” à mercê das práticas dominantes, desconsiderando, conseqüentemente, que professores e alunos são produtores de conhecimento. Coracini (1999b) alertou para o fato de o livro didático poder colaborar para a manutenção de uma determinada ideologia dominante. Sabemos que os livros didáticos buscam sempre uma linearidade no aprendizado, uma homogeneização nos procedimentos, sem mencionar a questão mercadológica envolvida; dessa forma, é compreensível que tal aspecto não esteja contemplado nesses documentos. Contudo, a ausência de orientação para que coordenadores, professores, orientadores pedagógicos

\footnotetext{
${ }^{67}$ Usamos a expressão "material didático" para indicar não somente livros que, porventura, possam ser adotados em algumas instituições de ensino superior, mas também para indicar a seleção de textos ou outros recursos que possam servir de fonte para discussões que propiciem a aprendizagem.
} 
estejam alertas sobre o caráter problemático do material didático e as implicações da sua escolha pode fazer com que antigas representações do livro didático e hábitos continuem a vigorar. $^{68}$

Ainda com relação aos conteúdos curriculares, vemos na formulação: "reflexão teórico-crítica com os domínios da prática" outro exemplo de construção de pares, aspecto que temos buscado identificar no discurso desses documentos. Estamos apontando para os efeitos produzidos nas construções "reflexão (teórico-crítica)” com “domínios (da prática)", ou seja, entendemos que o par teoria/prática está posto nessas orientações, com ênfase, sobretudo, para a prática. Note-se o efeito da incisa "essenciais aos profissionais de Letras", que produz um efeito fundante ou estruturante na formação de professores. Considerando a forma e o objetivo das DCL, entendemos que a maneira pela qual essa questão foi introduzida propicia a instauração da noção de que essa dicotomia é parte inerente do professor. Vejamos o que Popkewitz nos diz sobre esse ponto:

I consider the distinction of "practice" and "theory" in the teaching and teacher education of the program as part of the scaffolding that constructs the teacher. [...] Practice does not stand outside of theory but is itself a theoretical concept that "tells" one how the world is to be held together and reflected upon (1998, p. 79-80).

A questão que merece ser posta, na nossa visão, é pensar, conforme postula esse educador, não em construções binárias, mas sim como pares que são partes de um mesmo processo. Vale ressaltar a sugestão de que "os domínios da prática” devem priorizar a "abordagem intercultural", conforme transcrito acima. Atentemos para o caráter disjuntivo nessa formulação, pois entendemos que a questão da abordagem intercultural (ênfase em sua priorização) em si já envolve um conceito teórico. Ou seja, há uma sugestão para se valorizar a prática (constituição do par teoria/prática), mas, ao mesmo tempo, essa prática remete a uma teoria que lhe é inerente. Ao instaurar uma disjunção, um desses pólos (prática) volta a ligarse com o outro como resultado dessa separação. Além dessa formulação, há também, na seqüência, outra proposta: "o processo articulatório entre habilidades e competências no curso de Letras pressupõe o desenvolvimento de atividades de caráter prático durante o período de integralização do curso" (CONSELHO NACIONAL DE EDUCAÇÃO / CÂMARA DE EDUCAÇÃO SUPERIOR, 2001, p. 31, grifos nossos). Reiteramos comentário

\footnotetext{
${ }^{68} \mathrm{O}$ trabalho de Coracini sugere algumas razões que levam professores a adotar um livro didático, entre elas: os alunos ficam perdidos sem ele, o material representa economia de tempo no preparo de aulas etc.
} 
elaborado sobre a formulação anterior, pois, nesse, a divisão entre teoria e prática é também sugerida. A articulação entre habilidades e competências implica, igualmente, um conceito teórico. Lembramos reflexão sobre a questão das competências mencionadas no trabalho de Laranjeira (2003) e no capítulo anterior, sobre as condições de produção das Diretrizes Curriculares. Também com o objetivo de remeter o leitor a outros trabalhos, anteriormente citados, lembramos que argumentamos (nos mesmos Capítulos 2 e 3) como vimos que alguns modos de dizer podem dar início ou reforçar a dicotomia teoria/prática na educação (THERRIEN, 2002; ESTRELA, 2002; FERRAÇO, 2005). Com isso, perde-se de vista o espaço entre esses dois pólos, que acreditamos ser o campo da produção, da (re)formulação dos sentidos. Como os conceitos se bifurcam naturalmente, se a ambivalência subjaz, caberia pensar sobre a articulação desses pólos como formas complementares, como expressões do mesmo. Desse modo, a reflexão poderia centrar-se em formas de aproximação desses "opostos" ao invés de intensificar dicotomias. No entanto, percebemos no discurso desses documentos efeitos que reforçam a disjunção.

Sobre a estruturação do curso, há uma solicitação para que se observe o que as DCF preconizam, em seu Art. $5^{\circ}$. Trecho que transcrevemos abaixo:

Art. $5^{\circ}$ O projeto pedagógico de cada curso, considerado o artigo anterior, levará em conta que:

I. a formação deverá garantir a constituição das competências objetivadas na educação básica;

II. o desenvolvimento das competências exige que a formação contemple diferentes âmbitos do conhecimento profissional do professor;

III. a seleção dos conteúdos das áreas de ensino da educação básica deve orientarse por ir além daquilo que os professores irão ensinar nas diferentes etapas da escolaridade;

IV. os conteúdos a serem ensinados na escolaridade básica devem ser tratados de modo articulado com suas didáticas específicas;

V. a avaliação deve ter como finalidade a orientação do trabalho dos formadores, a autonomia dos futuros professores em relação ao seu processo de aprendizagem e a qualificação dos profissionais com condições de iniciar a carreira. (CONSELHO NACIONAL DE EDUCAÇÃO / CONSELHO PLENO, 2002a, grifos nossos).

A apresentação dessa orientação, disposta em forma de artigos, parágrafos únicos, itens e subitens, imprime ao documento um efeito legislador, que deixa os indivíduos submissos a ela. Vemos essa marca como reflexo de um discurso jurídico, portanto. Notemos como as formas deônticas nas formulações (verbo "dever" em algumas de suas variantes: deverá, deve, devem), em conjugação perifrástica com verbos no infinitivo (garantir, orientar- 
se, ser, ter) torna o discurso marcadamente intimidador. Lembramos, aqui, reflexões de Foucault (2003b) sobre o poder disciplinar que postula que a vigilância hierárquica, a sanção normalizadora e o exame são meios de controle, parte de um processo de adestramento dos corpos e do espírito. Acreditamos que as formulações presentes nesse artigo das DCF (e em vários outros), com o verbo "dever", funcionam na direção de auxiliar a padronizar uma prática homogênea não apenas em relação à estrutura dos cursos, mas também no que diz respeito aos conteúdos, métodos, procedimentos, materiais didáticos etc. $\mathrm{Na}$ verdade, a perspectiva foucaultiana de poder contribui para visualizarmos nesses documentos, de uma maneira geral, formas de conduta que o Estado pretende criar; como por exemplo, o caráter marcadamente empresarial na escola, ou ainda, enunciados que - por não apresentar clareza acabam por incentivar e legitimar práticas homogeneizadoras. Nossa reflexão sobre esse aspecto retoma, dessa maneira, comentário anterior a respeito da determinação/seleção de características que sejam necessárias, importantes, essenciais para a estrutura do curso em oposição àquelas que são contingentes. De modo semelhante, o mesmo processo poderá ocorrer quanto a essa questão da estruturação do curso. Ao se elaborar o projeto pedagógico, na tentativa de buscar elementos (partes) para compor esse projeto (conteúdos, disciplinas, módulos, temas etc.), poderá haver um contínuo deslizar entre os elementos considerados importantes para poder "cumprir" as orientações postuladas e aqueles que não são contingentes, portanto.

A complexidade dos temas com os quais temos nos deparado nas Diretrizes Curriculares, tais como "novas tecnologias", "termos éticos", "flexibilidade", "diversidade", entre outros, nos faz lembrar trabalho de Souza (2003) sobre políticas curriculares. Segundo a autora, diante da complexidade de determinados conceitos apresentados nos Parâmetros Curriculares, "o professor experimenta uma espécie de sensação de culpa que o remete ao lugar da incompetência” (p. 344) por não compreender algumas orientações nem torná-las factíveis. Outra questão levantada pela autora é sobre a transversalidade. Para ela, alguns temas (meio ambiente, ética, pluralidade cultural etc.) acabam se transformando em disciplinas escolares por serem considerados "produto da análise do governo" (p. 340). Desse modo, a análise da pesquisadora nos apóia na ênfase para um exame minucioso acerca dos conceitos apresentados nas Diretrizes Curriculares para que temas pluridisciplinares não acabem se tornando disciplinas em si. 


\subsection{Avaliar ou estigmatizar?}

Passemos para a última seção das DCL, que trata da questão da avaliação. Observemos as seguintes formulações que tratam desse item, primeiramente nas DCL para, em seguida, compará-las com as sugestões propostas nas DCF:

A avaliação a ser implementada pelo colegiado do curso de Letras deve constituir processo de aperfeiçoamento contínuo e de crescimento qualitativo, devendo pautar-se:

- pela coerência das atividades quanto à concepção e aos objetivos do projeto pedagógico e quanto ao perfil do profissional formado pelo curso de Letras;

- pela validação das atividades acadêmicas por colegiados competentes;

- pela orientação acadêmica individualizada;

- pela adoção de instrumentos variados de avaliação interna;

- pela disposição permanente de participar de avaliação externa. (CONSELHO NACIONAL DE EDUCAÇÃO / CÂMARA DE EDUCAÇÃO SUPERIOR, 2001, p. 31, grifos nossos).

Art. $8^{\circ}$ As competências profissionais a serem constituídas pelos professores em formação, de acordo com as presentes Diretrizes, devem ser a referência para todas as formas de avaliação dos cursos, sendo estas:

I. periódicas e sistemáticas, com procedimentos e processos diversificados, incluindo conteúdos trabalhados, modelo de organização, desempenho do quadro de formadores e qualidade da vinculação com escolas de educação infantil, ensino fundamental e ensino médio, conforme o caso;

II. feitas por procedimentos internos e externos, que permitam a identificação das diferentes dimensões daquilo que for avaliado;

III. incidentes sobre processos e resultados. (CONSELHO NACIONAL DE EDUCAÇÃO / CONSELHO PLENO, 2002a, grifos nossos).

Para abordarmos esse item da avaliação, vale lembrar, novamente, a interpretação de Foucault (2003b) sobre um dos mecanismos de poder disciplinar: o exame. Sua reflexão acerca desse tema preconiza que "o exame supõe um mecanismo que liga um certo tipo de formação de saber a uma certa forma de exercício de poder" (p. 156). Sintetizando o que nos diz esse pensador, o exame é uma estratégia do poder que, de maneira tácita, transforma seus "súditos" em objetos. Isso pertence a uma parte daquilo que esse filósofo designou como um dos três modos de objetivação do sujeito explicitados em seu texto "The subject and power" (1982/1983, p. 208), no qual ele sintetiza e discute os objetivos de suas pesquisas. Voltando à sua reflexão sobre o exame, outro postulado revela que, além da transformação em objeto, os alunos (empregamos esse termo, pois é o que nos interessa neste trabalho) passam a ser considerados por meio de documentos e registros. Isso nos leva a sua última postulação sobre o exame que diz respeito ao indivíduo visto como um "caso". Ou seja, olhar os alunos como 
casos que podem ser estudados, medidos, classificados, acaba por facilitar que o poder continue a interferir e a definir o que deve ser mantido, excluído, alterado etc.

Ampliando essa reflexão, vale, então, observar a formulação "disposição permanente de participar de avaliação externa" presente nas DCL, que vemos como tradução das DCF, sugerindo que a avaliação dos cursos seja feita por "procedimentos internos e externos". Voltando à reflexão de Foucault sobre os modos de objetivação, podemos acrescentar que tal formulação revela que a estruturação dos cursos deve estar submetida a práticas de divisão e conseqüente classificação. Cabe interrogar se tais práticas não ajudariam a criar um conteúdo curricular visando somente à preparação, ao treinamento para a obtenção de "sucesso" nessas avaliações. Ou seja, corre-se o risco de essas práticas avaliativas atuarem simplesmente como formas que estigmatizam e rotulam. Lembramos que instrumentos como ENADE (Exame Nacional de Desempenho de Estudantes), ENEM (Exame Nacional do Ensino Médio), entre outros, acabam sendo maneiras de catalogar, classificar resultados e, por meio deles, alunos e professores. Os rankings acerca das instituições submetidas a tais exames, constantemente, divulgados e explorados pela mídia exemplificam nossa asserção. Com isso, não pretendemos assumir posição contrária a tais mecanismos de avaliação, pois entendemos que podem gerar competitividade, levando aquelas instituições relacionadas na base desses rankings a buscar aperfeiçoamentos na área pedagógica, curricular etc. A questão que colocamos aqui é a de investigar se os processos de avaliação, baseados nas propostas das Diretrizes Curriculares, serão amplamente discutidos e (re)definidos. Entendemos que não é tarefa fácil detalhar o que seria uma avaliação vista como "processo de aperfeiçoamento contínuo". Nossa crítica não é com relação à ausência dessa elaboração no texto, tampouco que a questão da avaliação deva ser (re)definida a partir dos documentos mencionados. Nossa argumentação é no sentido de salientar que a ausência de detalhamento pode reforçar a complexidade do tema. Outrossim, por supormos que no interior das instituições de ensino as discussões exaustivas sobre a questão da avaliação são raras, nossa hipótese é que as práticas avaliativas continuarão a contribuir para perpetuar rituais disciplinadores que, ao invés de propiciar crescimento intelectual e crítico, acabam por validar prejulgamentos sobre grupos, níveis de aprendizagem e local de formação dos professores (instituições de ensino superior).

Sublinhamos que os adjetivos "periódicas" e "sistemáticas", presentes nas DCF para descrever as formas de avaliação, foram traduzidos nas DCL pelas locuções adjetivas: "processo de aperfeiçoamento contínuo e de crescimento qualitativo" ou ainda, "instrumentos 
variados de avaliação". Observamos a proximidade desses termos que poderíamos justificar por meio da relação interdiscursiva dessas formações (ORLANDI, 2002). Vemos, ainda, que os termos pertencem a uma mesma família parafrástica, segundo Pêcheux e Fuchs $(1975 / 1997) .{ }^{69}$ Entretanto, para o que nos interessa nessa análise, cabe observar que, em ambos os documentos, os adjetivos contribuem para criar esse efeito de opacidade no discurso. Advogamos, dessa forma, que a diluição da concepção das práticas avaliativas pode continuar a transformá-las em mecanismos que apenas pontuem, classifiquem e dividam os alunos. Ou seja, divisamos, novamente, outro momento no qual conceitos se bifurcam, criando pares que acabam por revelar a mesma origem constitutiva, que aqui denominamos avaliar/estigmatizar. No caso, os objetivos da avaliação preconizados para promover "aperfeiçoamento" e “crescimento" poderão também ser desviados do seu propósito, figurando como indicadores que ajudarão a manter ou a criar designações para alunos e instituições.

\subsection{Algumas decorrências}

Pelas reflexões expostas neste capítulo, contando com contribuições de teóricos educacionais, acreditamos que, de um modo geral, essa análise possibilitou-nos ponderar sobre algumas questões que pretendemos investigar nos cursos de formação de professores, no capítulo a seguir. À maneira de outros países, que relacionaram as reformas educacionais a mudanças de outras áreas da sociedade, no Brasil, a partir das Diretrizes Curriculares, vimos como as mudanças são vinculadas às transformações no mercado de trabalho e profissional. Sobre o surgimento de palavras de ordem decorrentes de políticas que viajam, notamos como a palavra "flexibilidade" se constituiu prioridade na formação, conforme já havíamos sinalizado, nas conclusões do capítulo anterior. Outros termos ou expressões recorrentes ainda são: "diversidade", "práticas investigativas", "tecnologias da informação", "materiais de apoio inovadores" e "colaboração e trabalho em equipe". Conforme já enfatizamos, acreditamos que esses conceitos devem ser cuidadosamente observados na realidade escolar, incluindo aqui, reformas curriculares, projetos pedagógicos e cursos de formação de professores, com o objetivo de entender como os sujeitos envolvidos nesse processo atribuem sentidos a essas concepções. Sinalizamos que, de acordo com nossa ótica, essas palavras

\footnotetext{
${ }^{69}$ Para os autores, "a produção do sentido é estritamente indissociável da relação de paráfrase” (p. 169), desse modo, permitimo-nos afirmar que os termos analisados apresentam aproximações semânticas, mantendo entre si uma "matriz de sentido".
} 
podem assumir finalidade puramente mercadológica. Esse é um dos aspectos que pretendemos investigar nos capítulos que se seguem. Sobre a redistribuição de obrigações, apontamos que a qualidade "autonomia", que deve ser atribuída ao aluno, causa esse efeito de transferência de deveres; o aluno, portanto, passa a figurar também como agente na sua formação.

No decorrer do estudo, apresentamos a disjunção como mecanismo para criação de pares, de bifurcações de sentidos, resultado de uma ambivalência, que vemos sempre presente nas reformas curriculares e, especificamente, nos assuntos propostos nas Diretrizes Curriculares. Assim sendo, considerando alguns efeitos produzidos pelo discurso na forma de construções disjuntivas com relação a temas como o perfil do aluno, a avaliação, o conteúdo curricular, somados, ora à complexidade dos conceitos discutidos (flexibilidade, diferença, o outro etc.), ora ao "silenciamento" sobre alguns tópicos (termos éticos, livro didático, valorização do contexto), somos levados a partilhar do modo como Popkewitz (2006) vê a presença do par "hope/fear" relacionado a reformas curriculares na atualidade, conforme algumas considerações discutidas no capítulo anterior, sobre as condições de produção desses documentos.

Para maior clareza do que precede, sintetizamos os cinco momentos nos quais percebemos no discurso o delineamento desse par formado pela esperança, o investimento da proposta das DCL (hope) e pela incerteza, a contingência, o medo da não-realização (fear). Ou seja, junto com a aplicação de um esforço para se atingir uma meta, há também o risco inerente a essa aplicação ou a possibilidade de o objetivo não se concretizar. Apresentamos o primeiro momento quando analisamos as formulações sobre o papel da universidade. Nesse, há orientação para que ela possa intervir na sociedade e transformá-la em termos éticos (hope) e não simplesmente ser reflexo da sociedade (fear). Em outras palavras, a universidade é pensada para ser uma instância criadora e transformadora da sociedade, mas, pode, em última análise, ser apenas o reflexo dela. No segundo momento, a respeito daquilo que vimos como palavra de ordem (flexibilidade), apresentada nos princípios norteadores das DCL, postulamos a formação do par flexibilidade/rigidez. A flexibilização curricular proposta (hope) é pensada para responder a demandas sociais, rompendo com a rigidez estrutural dos cursos. Ou seja, o par "rigidez" (fear) já está posto, há um efeito de que ele seja pré-existente. 
Sobre o perfil dos formandos, considerando a forma como as competências e habilidades foram sugeridas (por meio de conceitos complexos ou densos), defendemos a existência do par que designamos como necessário/contingente (terceiro momento). Isto é, considerando a complexidade ou a opacidade dos conceitos, supomos que os debates no interior dos cursos de formação de professores possam ocorrer de maneira disjuntiva, oscilando entre conteúdos que sejam pensados como necessários, importantes para a "completude" da formação (hope) e outros que possam ser postergados ou tangenciados, contingentes, portanto (fear). Entendemos que, em qualquer escolha, em qualquer nível, haverá essa separação entre necessário e contingente, entretanto, o que questionamos é o modo como tal separação pode ocorrer, quando se pensa em requisitos constitutivos de um determinado perfil profissional.

Os dois últimos momentos, nos quais também advogamos a existência do par "hopelfear", foram apontados nos itens que tratam da questão dos conteúdos curriculares e da avaliação. No quarto momento, então, sugerimos que a formulação "articular a reflexão teórico-crítica com os domínios da prática - essenciais aos profissionais de Letras” reforça a dicotomia teoria/prática já presente nas discussões educacionais. Mas o fato que destacamos aponta para o termo "articulação" como uma proposta de investimento, a possibilidade de sua realização (hope), que vem, ao mesmo tempo, recortada pela incisa "essenciais aos profissionais de Letras", que, da nossa ótica, provoca um efeito de reforço da dicotomia (fear), contrariando ou enfraquecendo, por conseguinte, a noção de investimento na articulação entre os dois pólos. Em outras palavras, a aposta é na articulação, mas ela pode também não ocorrer; nesse caso, busca-se garantir que o aspecto fundamental na formação seja a prática.

Finalmente, no último momento, tratamos da questão da avaliação. Argumentamos que o caráter eminentemente jurídico das orientações, somado aos efeitos de opacidade que os adjetivos provocaram e formulações difusas como "disposição permanente de participar de avaliação externa" nos ajudaram a pensar na construção de um par que vimos como avaliar/estigmatizar. Não obstante a ausência de materializações lingüísticas que nos guiassem para a constituição desse segundo pólo (estigmatizar), baseamo-nos nas reflexões de Foucault (2003b) sobre os mecanismos de poder disciplinar e, a partir delas, teorizamos sobre o desvio, o deslizamento do objetivo de avaliar para aperfeiçoar e crescer (hope) para propósitos apenas classificatórios (fear). 
Nos capítulos seguintes, pretendemos avançar nossa discussão sobre algumas reflexões suscitadas nesse e em capítulos precedentes. Em primeiro lugar, conforme já esclarecemos, à luz das reflexões de Bauman (2001) sobre a modernidade líquida, buscaremos entender como é possível pensar sobre desregulamentação de deveres em um curso de formação de professores. Partindo do estudo de Lindblad e Popkewitz (2004a) sobre políticas e conceitos que viajam e se transformam, visaremos identificar nos discursos de professoresformadores e alunos, nas duas instituições pesquisadas, a manifestação de algumas dessas políticas ou palavras de ordem, tentando entender como elas são pensadas ou contextualizadas. 


\title{
CAPÍTULO 5
}

\section{O IMPOSSÍVEL DE DIZER: \\ O DISCURSO DA FORMAÇÃO DE PROFESSORES DE INGLÊS (INSTITUIÇÃO 1) ${ }^{70}$}

[...] a evocação da "complexidade da situação" serve para nos livrar da responsabilidade de agir.

Slavoj Žižek. Um mapa da ideologia.

\begin{abstract}
Neste capítulo, voltamos-nos para a questão da ambivalência na dimensão do discurso didático-pedagógico, investigando, especificamente, as concepções de formação de professores de inglês. Reiteramos que estamos investigando quatro diferentes dimensões (focos de ocorrência da ambivalência) em nosso estudo. Na primeira dimensão, apresentada no Capítulo 3 da Parte I (seção 3.2), mostramos, em nível mundial, os deslizamentos de sentidos de algumas políticas educacionais. Em seguida, na seção 3.4, voltamo-nos para a segunda dimensão ao tratarmos das condições de produção das Diretrizes Curriculares. No Capítulo 4 da Parte II, nosso interesse centrou-se nas bifurcações de sentidos das orientações propostas em tais documentos (terceira dimensão). Assim, este e o próximo capítulo compõem a quarta e última dimensão da ambivalência que propusemo-nos a investigar ao longo do trabalho, na qual o foco será o discurso da formação de professores de inglês. Nesse ponto, cabe-nos esclarecer que a construção do nosso objeto discursivo partiu de entrevistas realizadas, cujas questões propostas foram as seguintes:
\end{abstract}
a) Para o professor-formador:
1) Como você se vê formando professores?
2) Como vê esse aluno, futuro professor?
3) Que tipo de trabalho faz com seus alunos que julga importante para sua formação?

b) Para o aluno:

1) Como você se vê fazendo um curso de formação de professores?

2) Como vê seus professores-formadores?

\footnotetext{
${ }^{70}$ Por razões éticas, esse é o modo que adotamos para nos referir à primeira instituição pesquisada.
} 
3) O que esse curso deve fornecer?

Neste capítulo, trazemos resultados da pesquisa realizada numa instituição de ensino superior, privada, fundada há cerca de 40 anos. Nela, realizamos 14 entrevistas, sendo cinco com alunos do curso de licenciatura em letras, com habilitação dupla: português/inglês e nove com professores-formadores do mesmo curso. Os professores-formadores e alunos selecionados para as entrevistas eram membros de um grupo de pesquisa do qual também atuávamos como pesquisador durante o ano de 2005. Assim, o grupo congregava professoresformadores ministrantes de disciplinas pedagógicas (didática, metodologia do ensino etc.) como também das disciplinas específicas (língua inglesa, língua portuguesa e suas literaturas). O curso de licenciatura da Instituição 1 possui duração de três anos.

Optamos por dividir o presente capítulo em quatro seções. Na primeira, além de apresentarmos as categorias de análise mobilizadas, quais sejam: a polifonia enunciativa, a negação e a narrativização ${ }^{71}$, argumentamos que há no discurso analisado um efeito de indeterminação e indefinição sobre a concepção de formação de professores de inglês obtido por meio desses modos lingüísticos e discursivos de dizer. Na segunda seção, partindo do pressuposto de que a concepção sobre a formação de professores de inglês tem seu sentido diluído, indefinido, distanciado, investigamos sinais no discurso que sugerem a constituição de um pacto tácito sobre a impossibilidade de formar um professor de inglês, em face do contexto apresentado. Na terceira seção, por meio de uma categoria de análise nomeada "linearização", exploramos a maneira como as atividades docentes são seqüenciadas, podendo provocar um efeito de adiamento da formação do futuro professor de inglês. Na quarta e última seção, apresentamos algumas considerações sobre o discurso analisado, na Instituição 1.

\subsection{Efeitos de instabilidade e indeterminação no discurso da formação}

Iniciando a análise e, com isso, já apontando elementos que subsidiam nossa tese, traremos, primeiramente, três excertos a fim de mostrar, separadamente, como a polifonia

\footnotetext{
${ }^{71}$ Termo emprestado do trabalho de Bertoldo (2003, p. 161) que analisa "o discurso pedagógico da lingüística aplicada". Conforme sua análise, o professor dessa disciplina cumpre função de narrador ao testemunhar sobre sua experiência como conhecedor da área. Ao fazê-lo, o professor ordena sua experiência, seguindo uma seqüência temporal, "narrativizando-a", daí nossa inspiração para adotar o termo em nossa pesquisa, de modo semelhante.
} 
enunciativa, a negação e a narrativização ${ }^{72}$ produzem efeitos de indeterminação e instabilidade no discurso da formação de professores de inglês. Em seguida, ampliaremos esses focos, mantendo tais categorias a fim de observarmos os efeitos gerados por meio desses modos de funcionamento discursivo, no decorrer do estudo.

O primeiro aspecto que destacamos, no discurso dos sujeitos analisados (aluno e professor-formador), trata da sua constituição pelo discurso do outro (BAKHTIN, 2003). Ou seja, como o aluno é representado no discurso do professor-formador e vice-versa. Buscaremos demonstrar, com essa categoria de análise, como diversas vozes se mesclam, auxiliando na construção de uma representação desses sujeitos e, por meio dela, da formação de professores de inglês. A primeira possibilidade com a qual trabalhamos refere-se a formas explícitas da heterogeneidade, conforme estudo de Authier-Revuz (2001, 2004). Partindo da teoria bakhtiniana do dialogismo, a autora postula que, em todo discurso, o enunciador sempre inscreve um outro por meio de marcas lingüísticas, percebidas na negociação que o sujeito falante realiza com o heterogêneo em seu discurso. Por meio da reprodução (imitação) de vozes, ora do aluno, ora do professor-formador, essa forma de conotação autonímica (fragmento "outro" integrado à cadeia discursiva) instaura, de modo incessante, um "estatuto outro" no discurso dos sujeitos analisados, tornando-o saturado de marcas "outras" que o deixam volátil, instável, fluido ${ }^{73}$.

Iniciamos com a apresentação de alguns trechos das entrevistas que tratam do perfil do aluno, de expectativas com relação ao magistério e algumas formulações que abordam a formação que os alunos trazem do Ensino Médio. Vejamos o excerto ${ }^{74}$ a seguir, no qual encontramos uma descrição sobre esse aluno do curso de licenciatura:

Excerto $1 \quad \mathrm{P} 3^{75}$ : bom... eu vejo o aluno um pouco perdido... na verdade... primeiro... porque ele tem muita dificuldade em relação a conteúdos... então eles... até têm consciência por exemplo que um curso de três anos... como é atualmente na maior parte das faculdades... é um curso que não supre todas as suas necessidades... então o aluno vem falar... "olha... eu tenho falhas nesse conteúdo... eu não vi isso... eu não li essa obra... eu não vi esse período..." seja lá o que for... esse tema... então eles têm dificuldade de conteúdo... ah... isso já é alguma coisa que os incomoda um pouco... ah... agora do ponto de vista prático... as experiências que os alunos têm... eles contam... por exemplo...

\footnotetext{
72 Entendemos que, no presente corpus, tais processos ocorrem concomitantemente, razão pela qual optamos por manter as categorias referenciadas em uma mesma seção.

${ }^{73}$ No sentido em que o termo é trabalhado por Bauman (2001).

${ }^{74}$ Orientamos que alguns excertos serão retomados, em outros momentos, com diferentes objetivos.
} 
quando eles fazem estágio... ou então quando eles têm que preparar uma aula e expor... eu os vejo também um pouco perdidos... porque... talvez não só perdidos... desanimados também... porque eles escutam as... os testemunhos dos colegas... dos outros professores... e esses testemunhos em geral são em relação à escola pública... e a gente sabe que a escola pública passa por uma fase bastante crítica... então eles ficam um pouco desnorteados... alguns ainda não têm aquele ideal que é... "eu quero trabalhar... eu quero ser professor... eu quero ir para a escola pública... eu quero tentar mudar a situação..." [...] agora se eu fosse pesar tudo na balança... eu diria que há muito mais... que há muito mais... éh... aspectos negativos... não é?... os alunos estão muito mais preocupados... muito mais perdidos... muito mais... até desinteressados do que os aspectos positivos... essa é a impressão que eu tenho...

No excerto acima, a "dificuldade em relação a conteúdos", no caso específico do professor-formador entrevistado, diz respeito a obras e períodos da literatura brasileira. Tal dificuldade é referenciada no discurso por meio de formulações (vozes) atribuídas ao aluno: “olha... eu tenho falhas nesse conteúdo... eu não vi isso... eu não li essa obra... eu não vi esse período... [...] esse tema”. É esse o sentido da polifonia enunciativa que vemos presente no discurso aqui analisado (entrecruzamentos de diversas vozes). Vale notar que ao empregar formas nominais na qualificação do sujeito (particípio sem auxiliar), o uso dos termos "perdidos", "desanimados", "desnorteados" e "desinteressados", além de se confundirem com adjetivos - característica mista, portanto - revela ainda o resultado de uma ação acabada, ou seja, isso já está posto, não há possibilidade de mudança, como em "perdidos", por ser o resultado de uma ação passada (professor-formador comenta a chegada do aluno e seu contato com o conteúdo). Acrescente-se a isso, ainda, o valor passivo dos verbos transitivos utilizados no particípio (perder, desanimar, desnortear, desinteressar) e formas modalizadoras como "não só", "um pouco", "muito mais até" que produzem um efeito de fragilidade e incerteza na adjetivação.

Com relação à vida profissional como futuro professor, pode-se "ouvir" também a polifonia presente ao se integrar à cadeia discursiva um fragmento "outro". A expressão metalingüística "que é" traz para a enunciação uma voz que, por meio do interdiscurso, ou seja, pelo "conjunto do dizível, histórica e lingüisticamente definido", nas palavras de Orlandi (1997, p. 89), nos sugere a descrição de um professor “ideal”. A modalização por meio do advérbio de tempo "ainda" torna a perspectiva da carreira docente duvidosa, incerta. Depreende-se que o padrão de professor, com o qual o professor-formador parece se identificar, não é encontrado nesse aluno, futuro professor. Há, desse modo, além da ausência

\footnotetext{
${ }^{75}$ Adotaremos o símbolo "P" para indicar o professor-formador. O numeral refere-se à ordem seqüencial da realização das entrevistas.
} 
de preparação prévia para a formação universitária, uma ausência de perspectiva profissional para o futuro professor de inglês.

No excerto seguinte, a falta de preparo dos alunos também é trazida. Vejamos como isso aparece:

Excerto 2 P1: [...] o primeiro trabalho mesmo é desmistificar... ah... desmistificar a obra, o autor, desmistificar tudo... e em segundo lugar é botar as pessoas pelo menos para tentarem ler alguma coisa... ler e... fundamentalmente... ahn... pelo menos tentar discutir isso a partir mesmo de uma formação mais precária que eles têm... quer dizer... as formações são sempre precárias né... [...] o desemprego aí de professores... aos milhares... não se dá por falta de (vaga)... se dá por incompetência mesmo... incompetência generalizada... incompetência decorre muito também dessa preguiça... né "ah eu não vou ler... né... eu não vou fazer... não vou isso... não vou aquilo"...

Com o excerto acima, introduzimos a segunda categoria de análise que mobilizamos: a negação; vista aqui, como mecanismo de descrição das aptidões ou ausência delas na definição do aluno. Para tanto, evocamos a concepção de negação elaborada por Ducrot (1984/1987). O lingüista propõe três formas de negação: metalingüística, polêmica e descritiva. Para ocorrer a negação metalingüística, segundo ele, é necessário que haja um enunciado positivo anterior, cujo locutor seja definido. $\mathrm{O}$ enunciado negativo contradiz "os próprios termos de uma fala efetiva à qual se opõe" (p. 203). Para esse caso, o autor apresenta o seguinte exemplo: "Pedro não parou de fumar; de fato, ele nunca fumou na sua vida" (p. 204). Como dissemos, é necessário supor que este dizer é uma resposta a um locutor que acaba de enunciar: "Pedro parou de fumar". Ou seja, a negação metalingüística produz um efeito de correção de uma fala anterior; Pedro não pode ter parado de fumar, pois, na verdade, nunca fumou. Nesse caso, a negação passa a ter um "valor de elevação" ao invés de seu "efeito habitual de 'abaixamento"” (p. 204).

Já no caso da negação polêmica, o efeito é sempre "rebaixador", pois ela é uma negação ou refutação de uma fala anterior. Segundo Ducrot (1987, p. 204), a negação polêmica "corresponde a maior parte dos enunciados negativos". Nesse caso, a negação não é entre locutores, como na negação metalingüística, mas entre enunciadores, pois a negação não rejeita os termos de um locutor anterior (autor expresso de um enunciado). ${ }^{76}$ Aqui, o

\footnotetext{
76 Guimarães (2002/2005), retomando estudos da teoria polifônica da enunciação de Ducrot (1987), define como "Locutor" (com maiúscula) o "lugar que se representa no próprio dizer como fonte deste dizer" (p. 23). Como
} 
enunciado afirmativo é construído no próprio interior da enunciação. O exemplo do lingüista é: "Pedro não é inteligente". Com isso, o enunciador rejeita não uma voz que possui origem determinada (um locutor), mas um enunciado originado de um discurso indefinido: "Pedro é inteligente".

Na negação descritiva, não é possível perceber a polifonia presente nas duas formas anteriores, pois, nesse acaso, a negação é para "representar um estado de coisas, sem que seu autor apresente sua fala como se opondo a um discurso contrário" (p. 203). Tomemos o exemplo proposto: "N, que não conhece Pedro, pergunta a $\mathrm{Z}$ o que pensa dele, e $\mathrm{Z}$ afirma 'ele não é inteligente"”. Ou seja, a contextualização nos permite inferir que tal formulação não retoma uma outra voz anterior, pois apenas descreve um "estado de coisas", podendo ser assim parafraseada: "Pedro é um imbecil”, sem sugerir alteração do sentido, da perspectiva de Ducrot.

Julgamos que a visão do lingüista nos auxilia a reconhecer, nas imitações trazidas nos excertos 1 e 2, marcas de negação polêmica. Em ambos os casos, há um dizer que esboça um propósito da não-execução das ações: “ah eu não vou ler... né... eu não vou fazer... não vou isso... não vou aquilo" (excerto 2). Do mesmo modo, no excerto 1 , o advérbio de negação "não" descreve experiências - ou a ausência delas - em: "eu não vi isso... eu não li essa obra... eu não vi esse período..." Ou seja esse tipo de negação coloca em cena dizeres esperados contrários e (possivelmente) formulados por um enunciador que fala do lugar de dizer de professor-formador. A negação, em tais formulações, produz então, um efeito “rebaixador", conforme análise de Ducrot (1987, p. 204). Assim sendo, essa representação esboça o perfil de um aluno pautado na ausência, na falta de preparo (conteúdo lingüístico ou literário) com o qual se possa iniciar sua formação. Podemos inferir também que o ponto de partida para iniciar a formação profissional está baseado em um painel movediço, incerto.

Voltemos nossa atenção, nos excertos 1 e 2, para a forma como a pessoa de quem se fala (aluno) é referenciada. O termo delocutivo é empregado para designar a pessoa de quem se fala (terceira pessoa). Na interpretação de Charaudeau e Maingueneau (2004, p. 310), esse

esse dizer é sempre socialmente situado, o autor acrescenta que o "Locutor", para se constituir como tal, enuncia de um lugar social. Por isso, o autor adota a designação "locutor-x" (com minúscula) para se referir aos diversos lugares sociais ocupados pela voz do "Locutor" (locutor-aluno, locutor-professor etc.). Quanto ao termo "enunciador", Guimarães o toma como "um lugar de dizer" (p. 25), isto é, uma perspectiva da qual se enuncia. Essa é a distinção adotada, neste trabalho. 
termo passa a ser classificado juntamente com o termo elocutivo (direção ao "eu") e alocutivo (direção ao "tu") como atos de enunciação ou locutivos. Segundos os autores, no alocutivo, o locutor implica seu interlocutor em seu ato de enunciação; enquanto que no elocutivo, o propósito na enunciação é situado nele mesmo. Com relação ao delocutivo, o locutor situa o propósito da sua enunciação sobre uma terceira pessoa. Em outras palavras, o locutor "deixa que o propósito [da enunciação] se imponha como tal [...]." Entendemos que com esse movimento, o locutor se exime da responsabilidade do propósito (da enunciação). Isso posto, vemos que a delocutividade, portanto, revela uma descrição atitudinal esperada por parte do aluno, no excerto 2: "ele deveria ler, ele deveria fazer isso e aquilo" ou ainda o cumprimento de certas exigências básicas para o curso, no excerto 1: "ele deveria ter visto esse conteúdo, período, obra ou tema". Obtém-se, com esse modo de dizer, um efeito de descomprometimento, de isenção dos sujeitos com relação ao que possa ser produzido a partir desse momento, considerando a "ausência" de preparo declarada nos dois fragmentos. ${ }^{77}$

Outra categoria mobilizada em nossa análise é a narrativização. Segundo Charaudeau e Maingueneau (2004, p. 342), para que haja narrativa, é necessário encontrarmos “a representação de uma sucessão temporal de ações". Tal conceito nos ajuda a identificar modos narrativos (mini-relatos) de constituição de subjetividades que trazem implicações na representação do discurso da formação. Na interpretação de Bruner (1996/2001, p. 44), a narrativa é "um modo de pensamento e um veículo de produção de significado". Em outras palavras, é por meio da narrativa que os indivíduos atribuem sentidos a suas vidas, para si e para os outros, permitindo, desse modo, a construção de identidades que os situem na sociedade em que vivem. Sendo assim, o autor sugere "elementos universais das realidades narrativas" (p. 129), dentre os quais, trazemos alguns que nos auxiliam no propósito deste trabalho.

Nos fragmentos narrativizados, é possível identificar "uma estrutura de tempo consignada", isto é, há na enunciação um desenrolar de eventos, sugerindo uma seqüência de início, meio e fim da ação narrada. Tal característica se aproxima da definição de Charaudeau e Maingueneau acima citada. O segundo elemento trata dos motivos das ações narradas. De

\footnotetext{
77 Cabe lembrar trabalho de Baghin-Spinelli (2003), apresentado no capítulo Formação de professores, por suscitar uma aproximação com a análise ora proposta. Ao investigar os processos identitários do professor brasileiro de inglês, a autora analisa alguns mecanismos enunciativos que constroem uma representação desse sujeito como "aquele que ocupa o lugar da falta e/ou da falha" (p. 197).
} 
acordo com Bruner (2001, p. 131) "as ações narrativas implicam estados intencionais". Isto significa dizer que, ao narrar, o indivíduo é movido por crenças, desejos, teorias e valores que subjazem ao processo narrativo. Tal elemento é classificado como: "as ações têm motivos". De fato, conforme pretendemos demonstrar adiante, alguns fragmentos narrativizados parecem provocar um efeito de envolvimento do professor-pesquisador ${ }^{78}$, suscitando uma atitude responsiva. A partir desse elemento, outros dois parecem decorrer: a "ambigüidade de referência" e a "negociabilidade inerente". Com o primeiro, aprendemos que o fato narrado está sujeito a questionamentos. O segundo elemento abre espaço para outras possíveis interpretações, gerando novas narrativas. Ou seja, em ambos os casos, trata-se da construção de realidades e não de uma realidade única. "A centralidade do problema" é outro elemento que nos faz identificar a presença da narrativização nos excertos apresentados. Com tal característica, o autor nos diz que os fatos narrados surgem a partir de "problemas". Com efeito, essa é uma noção basal presente nos dizeres a serem analisados, conforme iremos argumentar.

Para iniciar a análise dos excertos 3 e 4 a seguir, evocamos, também, o trabalho de Teixeira (2001, p. 277), que utiliza a denominação “expressões avaliativas” para designar não somente adjetivos como também particípios adjetivados (magoado), expressões preposicionais (sem sorte) etc., em sua análise. ${ }^{79}$ No tratamento com os verbos, a adjetivação recai sobre o próprio processo que o verbo nomeia. Para essa classe gramatical, a autora propõe uma divisão entre: verbos de sentimento de disposição favorável (amar, apreciar); verbos de apreensão perceptiva (parecer, dar a impressão de que) e os verbos de opinião (achar, crer, pensar). Esse é o ponto de nosso interesse para esta análise, pois observamos que, em momentos recorrentes, a qualificação desse aluno ocorre, então, por meio de uma sucessão de acontecimentos, mostrados, inicialmente, no excerto a seguir:

Excerto 3 P4: [...] eles não têm conhecimento de quase nada da língua... eles vêm com aquela... com aqueles conceitos magros e distorcidos de língua portuguesa... ah... e... eles vêm pra sala de aula sem base nenhuma... sem conhecimento... eu to falando de língua portuguesa... mas na verdade... eles não vêm com conhecimento quase nenhum... eles não vêm com uma postura que a gente espera para um nível universitário [...] é um aluno específico que tem mil

\footnotetext{
${ }^{78}$ A expressão "professor-pesquisador" refere-se ao autor deste trabalho.

79 Nesse trabalho, a autora parte do estudo de Kerbrat-Orecchioni (1980) que pesquisou procedimentos lingüísticos (shifters, modalizadores, termos avaliativos), pelos quais o locutor imprime sua marca na mensagem, dentre eles, os adjetivos. Após apresentar as classificações dos adjetivos e a divisão em categorias proposta por essa autora, Teixeira acrescenta uma categoria formada por palavras ou grupos de palavras de outras classes gramaticais que adquirem estatuto de adjetivo.
} 
problemas... a maioria vem do Estado com todas aquelas lacunas que já são... conhecidas... né [...] o que falta para eles... na verdade... é conteúdo... porque... a gente tenta né suprir essa lacuna de deficiência... de defasagem... mas não dá... você consegue... na verdade... pincelar algumas coisas ali...

Nesse excerto, o verbo "vir" no presente do indicativo, ora em sentenças afirmativas, ora negativas, assume função de "adjetivo" no plano descritivo; ou seja, a descrição do perfil desse sujeito é feita por meio de um verbo, que podemos encaixar, na classificação proposta por Teixeira (2001), como um verbo de opinião. As seqüências pseudo-adjetivadas com as expressões preposicionadas "sem base", "sem conhecimento" e do advérbio "quase", que, conforme Ducrot (1972/1977, p. 277), possuem também um valor negativo, são ainda sucedidas por uma oração relativa restritiva: "eles não vêm com uma postura que a gente espera para um nível universitário". Temos, então, com esse excerto, a exposição da narrativização como categoria de análise, pois podemos identificar: a) um tempo narrativo (chegada do aluno à universidade); b) a narração é motivada por uma crença (espera-se algo do aluno); c) a "postura" referida é algo discutível, conforme demonstraremos; d) a "realidade" representada pode ser redescrita e, finalmente, e) há um "problema" (conflito) com relação ao perfil do aluno. Baseamo-nos, ainda, em contribuição de Brandão (2000, p. 29-30) sobre os constituintes da estrutura da seqüência narrativa. Podemos identificar, no excerto 3, os seguintes itens: a) um agente da ação (aluno); b) há uma pequena sucessão de acontecimentos, na qual se cria uma tensão (efeito obtido pelo verbo “vir"); e, principalmente, c) um final na forma de uma avaliação: os alunos não apresentam uma postura que se espera para um nível universitário. ${ }^{80}$

Ampliando a reflexão sobre a postura que se espera para um nível universitário, (mas não se diz), Henry (1975/1990) nos fornece uma teoria de grande importância sobre o funcionamento discursivo das construções relativas determinativas ao introduzir a noção de efeito de "pré-construído" desse tipo de oração. Ou seja, tal tipo de construção traz, de maneira implícita, uma representação elaborada anteriormente. Podemos, de fato, observar que, por meio da interdiscursividade, o sujeito resgata em seu enunciado essa representação que está implícita no seu dizer, já "construída" (por professores-formadores ou pela instituição universitária) que diz respeito a certas normas de postura esperadas de um aluno

\footnotetext{
${ }^{80}$ De acordo com a autora, além dos três constituintes reunidos em nossa análise, a estrutura da seqüência narrativa deve conter ainda: 1) uma passagem de um estado para outro (por exemplo, da infelicidade à felicidade) por meio de acontecimentos encadeados; 2) um processo em que se constrói uma intriga com a integração dos fatos em uma ação única; e, 3) uma causalidade narrativa.
} 
universitário. No exemplo em questão, a descrição ocorre de maneira inversa; depreende-se que há um modelo ideal e consensual ("postura que a gente espera"), mas não é esse o perfil do aluno, naquela situação. Ou seja, essa qualificação é constituída num espaço entre uma situação "real" e o modelo esperado. O modelo "ideal” e esperado - que não é descrito - é dado pelo efeito de pré-construído.

Cabe-nos aqui chamar a atenção para a questão da postura esperada para um nível universitário, sob uma perspectiva discursiva. Tendo, também, como pano de fundo, o contexto da pós-modernidade, no qual as "verdades" são questionadas e a transitoriedade, a incerteza, a atitude de incredulidade ${ }^{81}$ parecem prevalecer, a questão que se impõe é legítima: que postura esperada é essa? Da mesma forma, cabe atentar para o efeito de indeterminação que os substantivos "deficiência" e "defasagem" incitam. Defasagem em relação a quê? Depreende-se que há uma diferença, um descompasso entre as duas fases (escolas estaduais para a universidade), porém, na cadeia discursiva, revela-se a impossibilidade de resgatar essa “diferença” ("mas não dá”).

Outro aspecto que se evidencia, na enunciação, diz respeito ao verbo "pincelar". Se tomarmos a acepção da palavra e considerarmos os deslizamentos inerentes da língua(gem), como podemos refletir sobre os sentidos do termo como um ato pedagógico? Estaria o professor-formador responsável por dar uma "nova" cor ao aluno (pintar), remediar (tomando "pincelar" em seu sentido stricto), agir na superficialidade por meio de "retoques" e complementos (em um sentido lato do termo)? Ou seja, seria sua função trabalhar com a aparência, com uma nova forma de representação? Com tais questionamentos, identificamos, na enunciação, a existência de um conflito, no qual coabitam certezas, idealismos, atitude missionária do professor, cujas responsabilidades são: prover "base", "conhecimento", um saber necessário para a vida acadêmica (a definir). Por outro lado, há o reconhecimento da impossibilidade, da incompletude, da diversidade e, sobretudo, da incerteza de como conviver com elas.

Perpassados que somos pelo discurso da modernidade, da ilusão iluminista do saber único, fixo, apreensível na sua totalidade, e, ao mesmo tempo, capturados em um momento de elasticidade, de fluidez, de transformações múltiplas e incessantes, que concepção de

\footnotetext{
${ }^{81}$ Cf. Lyotard, 1986.
} 
formação de professores é possível formular? Como formar um professor em face de tais características pós-modernistas, assumindo que tal discurso também nos constitui? Pelo que acabamos de refletir acerca do excerto 3 , reconhecemos, na enunciação, um efeito importante de indeterminação que pode acarretar, em toda a extensão da palavra, um distanciamento da formação.

Vejamos outros fragmentos narrativos que tratam do perfil do aluno, iniciando com P5: "os nossos alunos... eles têm... eles vêm... eu acho... muito mal acostumados... assim... sentam para receber... informações... só isso..." Nesse fragmento, destacamos o uso do verbo "vir", no presente do indicativo (“eles vêm...”), que dá início a um relato sobre esse momento inicial que é qualificado de forma bastante passiva: "sentam para receber... informações... só isso..." Formulação semelhante é encontrada no excerto ${ }^{82}$ abaixo:

Excerto $4 \quad$ P7: [...] eu acho que a formação universitária do jeito que é dada na área de língua inglesa é muito fraca porque os alunos entram mais fracos $[\ldots]$ os alunos eles chegam assim bem desorientados né... eles não sabem o que é a faculdade... eles não sabem o que se espera de alunos né... acho que também a gente peca por não falar né por já criticar que não sabem... comportamento éh desrespeitoso comportamento infantil né e eles assim... de uma hora pra outra eles têm que passar né daquele perfil de colegial primeiro... quando entram na faculdade já tem que ser adulto profissional já com metas estabelecidas né então assim é... éh... eu acho que... não é só culpa dos alunos a insuficiência... é culpa de todo um contexto que a gente vive... não tem muita perspectiva né... você não pode prometer... sabe aquela coisa de (falar sobre) carreira... ta ruim até pra quem ta dando aula né... então eu acho que eles assim... eu penso que eles saem bem frustrados porque eles não têm muita opção de mercado né então a gente tenta... prometer várias coisas... que vai ser melhor... tentar formar... incentivar para uma pós-graduação... eu acho que eles saem assim com vontade de estudar a formação deles não é...

A partir da prefixação negativa (“desorientados”), seguida das formulações: "eles [alunos] não sabem o que é a faculdade", "eles não sabem o que se espera de alunos", semelhantes à formulação apresentada no excerto 3 ("eles não vêm com uma postura que a gente espera para um nível universitário”), observa-se um efeito de pré-construído, isto é, tais noções remetem a um "conceito" pré-formulado. Contudo, tal formulação não é explicitada, é suposto que o aluno saiba o que é uma faculdade e o que se espera dele. A partir da formulação, cria-se uma imagem que descreve uma falta, realçada, principalmente, pela repetição do advérbio "não". No dizer de P7 (excerto 4), a formação universitária na área de língua inglesa "é muita fraca porque os alunos entram mais fracos". Acrescenta ainda que a

\footnotetext{
${ }^{82}$ Retomaremos parte desse excerto, em momento posterior, com outro objetivo.
} 
"insuficiência" não é somente dos alunos, pois a vê como resultado do "contexto que a gente vive". Nesse momento, temos, então, outro destaque para a questão da ausência de conteúdos, emergindo do discurso, um efeito de insatisfação não só com relação ao conhecimento da língua inglesa, como também, com relação ao ensino, de modo geral - fato que se torna um elemento impeditivo para incentivar os alunos.

Voltemo-nos para alguns aspectos que, do nosso entendimento, também se constituem em um conflito de perspectivas. Tomemos, novamente, os dizeres trazidos por P5: "os nossos alunos... eles têm... eles vêm... eu acho... muito mal acostumados... assim... sentam para receber... informações... só isso...” Depreende-se, com tal dizer, a existência de um arranjo escolar que é fruto de um ideal iluminista de educação (alunos recebem informações). Tal postura, vista como passiva pelo professor-formador, de acordo com esse modo de dizer, está impregnada no aluno ("eles vêm muito mal acostumados") como resultado de um processo de escolarização, no qual tal conduta foi alimentada e solidificada. Somando-se a essa análise, as formulações trazidas no excerto 4 nos levam a identificar, novamente, um painel de indefinição com relação ao papel da universidade e o que se espera dos seus alunos. Vemos que os alunos chegam "desorientados", desconhecendo seu papel e, sobretudo, da universidade. Tal indefinição é atribuída ao "contexto". No entanto, caberia interrogar, afinal, sob a responsabilidade de quem está o esclarecimento sobre a postura do aluno universitário e da universidade? Há consenso com relação a tal definição? Em face da materialidade lingüística, essa definição não é dita, é simplesmente suposta.

Desse modo, a partir das formulações de P5 e de P7 (excerto 4), observamos no discurso do professor-formador uma situação conflitante e conflituosa. P5 depara-se com uma postura (in)esperada, com a qual deve iniciar a formação (a passividade é criticada), mas uma postura contrária a essa não é proposta ou sugerida (não se sabe qual é?). Do mesmo modo, P7 (excerto 4) queixa-se do painel inicial encontrado (ausência de esclarecimento sobre papéis do aluno e da universidade), que, também, não é determinado, no ato da enunciação. Diante do exposto, advogamos que no discurso desses sujeitos, a indefinição, a indeterminação e, principalmente a instabilidade resultante de um contexto (pós-moderno?), no dizer de P7, com relação ao trabalho docente são postos em cena. Há, também, uma promessa, um incentivo para se buscar um "futuro melhor" ${ }^{\wedge 3}$. No fragmento analisado, os

\footnotetext{
${ }^{83}$ Voltaremos a esse ponto mais adiante.
} 
verbos "prometer", "tentar" e "incentivar" ajudam a criar a noção de um fazer educacional de natureza experimental, tornando o professor-formador um ponto de ligação, de transição que ajudará o aluno a buscar sua formação em outro momento futuro contingente ("eles [alunos] saem assim com vontade de estudar a formação deles”). Esse modo de dizer nos faz entender que a "formação" representa algo disfuncional que deve ser estudado, analisado. Como se fosse preciso tentar compreender que tipo de formação foi aquela.

Lembramos que, além da negação como forma de descrever os sujeitos e da narrativização como processo integrante na construção de concepções educacionais, vimos também tentando demonstrar, por meio da heterogeneidade discursiva, que há sempre um outro que se faz presente, ora pelo interdiscurso (um dizer que remete a outro discurso), ora pela polifonia na enunciação (multiplicidade de vozes do sujeito falante), mas sempre dando a conhecer na formulação, a presença de um elemento já afirmado anteriormente. Vimos argumentando que por meio desses modos de dizer, detectamos um efeito de instabilidade, de indeterminação, de não-fixação de sentidos. Tomemos outro exemplo, trazido no excerto seguinte, que revela uma forma não marcada da heterogeneidade mostrada ao fazer uso do discurso indireto:

Excerto 5 P6: [...] e o pessoal de letras é um pessoal maravilhoso porque eles escrevem... eles lêem... eles interpretam... eles se abrem a isso... e isso para o professor atualmente é um ganho... se bem que os professores da área específica acham que eles não lêem o suficiente... não escrevem o suficiente... mas eu que tenho um pouco dessa errância pelos outros cursos acabo tendo uhn... uma visão muito positiva deles...

Nesse exemplo, o enunciador não só menciona a "origem" $\$ 4$ do enunciado como também o emprega em seu dizer. Em um processo, também marcadamente narrativodescritivo, como vimos anteriormente (“o pessoal de letras é um pessoal maravilhoso porque eles escrevem... eles lêem... eles interpretam..."), P6 integra em sua análise um fragmento outro que atribui aos professores-formadores da disciplina específica da área de letras, iniciado pela expressão de retificação "se bem que", mostrando, desse modo, um mecanismo de negociação que coloca em crise seu "próprio" 85 dizer - marca, portanto, de heterogeneidade discursiva. Entendemos que esse fragmento traz à baila um conflito de visões

\footnotetext{
${ }^{84}$ Empregamos aspas para remeter ao fundamento da ilusão do sujeito de ser origem do seu dizer. Para Pêcheux (1997b), além dessa ilusão, chamada por ele de "esquecimento $\mathrm{n}^{\circ}$ 1", há uma segunda ilusão discursiva do sujeito: "esquecimento $n^{\circ} 2$ ". Nesse, o sujeito tem a ilusão de que o significado é único, ou seja, para ele há uma correspondência precisa das palavras no discurso com a realidade.

${ }^{85}$ Idem a nota anterior.
} 
acerca do aluno de letras. No discurso, a representação do sujeito como "bom" leitor, cuja capacidade interpretativa e de produção escrita lhe é inerente, parece-nos evidenciar uma característica da modernidade por sugerir uma rotulação (fixação) das identidades: alunos de letras escrevem, lêem e interpretam. Admitindo que tal representação faz parte do imaginário dos professores-formadores, vemos, no excerto 5, a captura de um dizer dos professoresformadores da área específica de letras que parece ir de encontro àquela noção cristalizada. É nesse sentido que supomos haver um conflito de concepções, pois há um painel que parece não se harmonizar com determinada visão (alunos não lêem e não escrevem o suficiente). Temos, com isso, outro momento no qual se depreende um efeito de indefinição, de indeterminação acerca do papel do professor de um curso de letras e do próprio curso de formação. Retrato que, para nós, parece ser fruto de uma condição pós-moderna. A fim de articular a formulação de P6 (excerto 5) com o dizer de P8 (da área específica), incluímos o excerto abaixo:

Excerto 6 P8: [...] às vezes eu sinto que é um curso muito superficial... não é... principalmente em língua... às vezes me dá... um pouco de medo... do... do conhecimento lingüístico que esse aluno tem pra passar para os futuros alunos deles... né... isso me dá um pouco de medo... assim... embora tenha aluno que diga... que vai sair daqui professor de português... eu questiono também... ((risos)) não só o inglês... como o português ou como em qualquer... a literatura... eu acho que falta... uma... acho que falta uma base mais sólida... lingüística...

Há, de certa forma, um efeito de consonância com a voz outra (professores-formadores da área específica) trazida por P6 (excerto 5), pois vemos aqui preocupação expressa na formulação: "me dá um pouco de medo do conhecimento lingüístico que os alunos irão passar para seus futuros alunos". P8 resgata em sua enunciação a questão da habilitação dupla (português/inglês) que parece funcionar como elemento camuflador das dificuldades conteudísticas dos alunos. Independente da opção escolhida, há uma demonstração de perplexidade diante da "falta de uma base sólida lingüística" em ambas as línguas.

Voltemo-nos a outras marcas da polifonia enunciativa que ajudam a criar no discurso o efeito de indeterminação e indefinição acerca da formação dos professores de inglês. A partir dos excertos 7, 8 e 9 a seguir, observemos, na argumentação de $\mathrm{A} 5^{86}$, a maneira como a

\footnotetext{
${ }^{86}$ Adotaremos o símbolo "A" para indicar o aluno. O numeral refere-se à ordem seqüencial da realização das entrevistas.
} 
formação do professor de inglês torna-se distanciada, transportada para um nível "ideal" inatingível.

Excerto 7 A5: eu me vejo mesmo como uma formadora de idéias... porque eu acho que... o professor... antes de qualquer coisa ele... ele forma idéias... ele joga conceitos... e:.: esses conceitos... é lógico... eles vão ser trabalhados durante o percurso todo que o aluno ta dentro da escola e::. ... deve ser... é meio que moldando... é como se o aluno... ele fosse realmente uma massinha e::: essa massinha você vai moldando... você vai... esticando daqui... vai colocando um pouco mais de cor do outro lado... e vai realmente moldando ele pra vida que seria::: da/na sociedade...

Nesse primeiro momento da enunciação (excerto 7) que trata do perfil do aluno, a indicação dêitica de pessoa nos permite enxergar a existência de quatro protagonistas no discurso: "eu" (aluno $=$ locutor $^{87}$ ), "ele" (professor $=$ delocutário), "você" (professor = alocutário "imaginado") e "ele" (aluno = delocutário). Para melhor acompanharmos essa movimentação do sujeito no discurso, evocamos aqui a noção de Pêcheux (1969/1997a, p. 82) que concebe o sujeito como "um lugar determinado na estrutura de uma formação social". Continuando sua análise, o teórico postula que esse lugar é "representado" em processos discursivos, característica que cria neles "uma série de formações imaginárias". A implicação decorrente desse conceito é a de que o sujeito não seja apenas social, mas também dotado de inconsciente (PÊCHEUX; FUCHS, 1997, p. 177). Em outro trabalho, Pêcheux (1997b, p. 133) retoma essa noção de sujeito, apresentando "uma teoria não-subjetivista da subjetividade". 88

As postulações de Pêcheux nos permitem olhar para o discurso de A5 de forma a identificar na sua argumentação traços dessas “formações imaginárias", por meio de uma série de deslizamentos que marcam, como diz o lingüista francês, "o funcionamento espontâneo da forma-sujeito" (1997b, p. 163). Lembrando que a questão inicial do professor-pesquisador objetivava obter uma qualificação do perfil do aluno, notamos que $\mathrm{E}_{1}{ }^{89}=$ locutor, expresso pelo pronome "eu", primeiramente julga ser "formadora de idéias", em seguida, desliza para a posição de um professor ideal (delocutário “ele") que nomearemos $\mathrm{E}_{2}$. Lembramos, aqui,

${ }^{87}$ Conforme esclarecemos, estamos empregando o termo no sentido em que é trabalhado por Guimarães (2005).

${ }^{88}$ Com esse estudo, na interpretação de Maldidier (2003, p. 70), "o tema da heterogeneidade em Pêcheux se esboça decididamente".

${ }^{89}$ Usaremos a forma "E" seguida de um numeral para designar um enunciador, ou seja, um ponto de vista do qual se enuncia, conforme propõe Guimarães (2005, p. 25), com base na teorização de Ducrot (1987). Destacamos que abordagens semelhantes também são encontradas nos trabalhos de Brandão (1998) e Orlandi (2001). 
contribuição de Weinrich (1964/1974, p. 61) sobre a função dos tempos verbais no discurso. Nesse estudo, a partir da subdivisão dos tempos verbais em dois grupos, o autor passa a fazer uma distinção entre mundo comentado e mundo narrado. Esse último, empregado em todos os tipos de relato - literários ou não - descreve eventos distantes, propiciando, dessa forma, aos interlocutores, uma atitude de pouco engajamento. Por outro lado, o primeiro (mundo comentado), utilizado no diálogo, no drama, no ensaio, faz com que o falante assuma uma atitude mais comprometida, de maior engajamento. Vejamos como tais efeitos de sentido são obtidos, no recorte que fazemos. Por exemplo, no excerto 7, o emprego do verbo "formar", no presente do indicativo expressa um mundo comentado, cuja característica principal é revelar uma atitude de engajamento, de comprometimento que coincide com a nominalização do termo "formadora". Desse modo, o painel inicial que encontramos vislumbra-se como um enunciador $E_{1}$ que, ao dizer, move-se para a posição de $E_{2}$, decorrência da coincidência dos vocábulos "formar/formadora" e do encadeamento explicativo iniciado pela conjunção "porque" acrescido de fragmentos que denotam ações desse $E_{2}$ ("ele forma idéias... ele joga conceitos”). Vale notar também, no que se segue, o efeito metafórico construído, iniciado pela locução comparativa "é como se”. De acordo com Menezes de Souza (2004, p. 123, nota 3), “a metáfora remete a algo que está no lugar de outra coisa e, portanto, substitui e mascara uma falta". ${ }^{90}$ Esse jogo de substituição inserido na argumentação de A5, somado aos encadeamentos enunciativos de origem "mista", cria no seu discurso um ato de coenunciação, um efeito de compartilhamento na tentativa de suprir uma falta. Essa formasujeito, então, de que nos fala Pêcheux (1997b, p. 163), se mostra disseminada em várias instâncias enunciativas, revelando, assim, essa falta que é constitutiva do sujeito e do dizer. Para o que nos interessa, a disseminação de vozes faz emergir do discurso uma cadeia de formulações justapostas que permite que os sentidos sobre a formação de professores se constituam de modo atemporal, anistórico, etéreo, elástico e líquido ${ }^{91}$.

Examinemos o modo como algumas atividades empreendidas durante a graduação são trazidas no discurso. Observamos, inicialmente, o emprego do pronome "você" $\left(\mathrm{E}_{3}=\right.$ professor = alocutário "imaginado") inserido em um processo narrativo-descritivo como um agente de procedimentos "pedagógicos" ("você vai... esticando daqui... vai colocando um pouco mais de cor do outro lado... e vai realmente moldando") investidos sobre o aluno (= "massinha"). Por meio de uma série de locuções verbais (vai moldando, vai esticando, vai

\footnotetext{
${ }^{90}$ Cabe ressaltar que para a $\mathrm{AD}$, o sentido das palavras é sempre metafórico.

${ }^{91}$ No sentido em que Bauman (2001) discute o termo.
} 
colocando) que possuem um efeito explicativo, deparamo-nos com uma sugestão do perfil de um professor "ideal".

Conforme vimos no excerto 7, A5 ( $\left.\mathrm{E}_{1}\right)$ move-se, por meio da posição-sujeito, primeiramente, para "ele" (professor = delocutário) que designamos por $\mathrm{E}_{2}$, e, em seguida, para "você" (professor = alocutário "imaginado"), que classificamos como E 3 . No próximo excerto (8), identificamos o desenrolar de um processo que supomos ilustrar o que Pêcheux (1997b, p. 171) denominou de "tomada de posição". Segundo o autor, esse é um processo pelo qual o sujeito se vê "como autor de seus atos", caracterizado, portanto, por uma aparente homogeneidade enunciativa, pois "a tomada de posição resulta de um retorno do Sujeito no sujeito" (1997b, p. 172). Na sua teoria, Pêcheux fala em um desdobramento da forma-sujeito entre "sujeito da enunciação" e "sujeito universal". 92 Ele explica, em seguida, que esse desdobramento assume três diferentes modalidades das tomadas de posição. Na primeira delas, ocorre uma superposição (sujeito da enunciação + sujeito universal), fazendo com que o sujeito mantenha-se assujeitado de forma consentida - posição que Pêcheux caracteriza como a do "bom sujeito" (p. 215). Na segunda modalidade ("mau sujeito"), o sujeito da enunciação se distancia do sujeito universal, buscando apartar-se da formação discursiva na qual se vê assujeitado. Finalmente, na terceira modalidade ("desindentificação"), esse sujeito da enunciação desloca-se da formação discursiva em que se encontrava, desfazendo, portanto, a forma-sujeito que lhe moldava para identificar-se com uma outra formação discursiva e, por conseqüência, com outra forma-sujeito. Exemplifiquemos, então, como vemos essa “fragmentação do sujeito", conforme palavras de Indursky (2000), no excerto a seguir:

Excerto 8 A5: [...] eu acho que é extremamente delicado ser professor... hoje em dia... e::: acho que essa profissão... ela é muito mais pra pessoas idealistas do que pessoas que simplesmente... que nem a gente vê... muito nas escolas... no meu caso... quando eu tava fazendo estágio e tudo mais... a gente vê muitas pessoas encarando o magistério éh... encarando a::: profissão de ser professor como um bico... como uma segunda profissão... quando... na realidade... não deveria ser isso... deveria ter pessoas realmente engajadas em modificar... o mundo... em transformar o mundo em... um local melhor... em transformar realmente pessoas em seres humanos completos... sabe... pessoas que pensam... pessoas que raciocinam... pessoas que não tão simplesmente... aceitando éh... o que a sociedade impõe... mas que elas vêem algum tipo de

${ }^{92}$ Para Pêcheux (1997b, p. 214), “os indivíduos são interpelados em sujeitos falantes (em sujeitos de seu discurso) por formações discursivas que representam na linguagem as formações ideológicas que lhes são correspondentes". Desse modo, "a interpelação do indivíduo em sujeito de seu discurso se realiza pela identificação (do sujeito) com a formação discursiva que o domina". Tal interpelação implica um desdobramento na constituição do sujeito do discurso em: "sujeito da enunciação" (locutor responsável pelos conteúdos postos) e "sujeito universal" (sujeito da ciência ou que se pretende como tal). 
informação... que elas vêem alguma coisa que ta sendo passada e elas vão pensar a respeito... elas vão falar "poxa... isso aí ta sendo passado... mas o que tem por trás disso?" sabe, "e ... que que isso interfere... sei lá... na economia... na política... na sociedade?" ... e e:: a gente vê muito pouco isso exatamente por fal/por essa falta de engajamento que existe... e isso eu acho uma pena também...

Conforme observamos, no excerto 7, há uma identificação atitudinal impressa no discurso ("eu" $\mathrm{E}_{1}$ : "formadora" = "ele" $\mathrm{E}_{2}$ : "aquele que forma"). Com a coincidência das posições de $\mathrm{E}_{1}$ com $\mathrm{E}_{2}$, temos a primeira modalidade de que nos fala Pêcheux (1997b, p. 215), caracterizada pela superposição do sujeito da enunciação $\left(E_{1}\right)$ com o sujeito universal $\left(E_{2}\right)$. Foi o que o autor chamou de "bom sujeito". Na seqüência (excerto 8), A5 transita para uma segunda tomada de posição, na qual critica, questiona, revolta-se contra um comportamento que julga ser disseminado por esse sujeito universal. Observemos o efeito modalizador do advérbio "extremamente" que inicia essa passagem, marcando, desse modo, a transição do "bom sujeito" para o "mau sujeito". A cadeia argumentativa que se segue revela um distanciamento progressivo desse sujeito universal, uma dissociação que podemos representar como $E_{1}-E_{2}$. Por meio de um argumento de autoridade, expresso pela locução verbal "estava fazendo" (estágio), tempo narrado, portanto, A5 se vê autorizado a contestar por enunciar de uma posição que não mais se iguala ao sujeito universal. É preciso notar, também, a mudança de designação genérica empregada por A5 ao referir-se a esse sujeito universal como "pessoas". Em outras palavras, A5 passa a questionar a forma-sujeito que até então ocupava ao criticar a falta de engajamento. Do ponto de vista da materialidade lingüística, tal efeito é obtido pela repetição do advérbio "realmente" que intensifica o efeito asseverativo do encadeamento iniciado pela forma verbal perifrástica de caráter proposicional "deveria ter".

Perseguindo a seqüência argumentativa de A5, temos ainda, um efeito de coesão referencial por meio do uso de expressões sinônimas "pessoas/seres humanos" para substituir, de forma totalizadora, a posição do aluno delocutário (também expresso por "ele" no discurso de A5), conforme vimos acima e que chamaremos de $\mathrm{E}_{4}$. Na verdade, esse efeito de coesão funciona como mecanismo de desidentificação de A5. Em outras palavras, após passar por uma modalidade de conjunção com a forma-sujeito do sujeito universal $\left(E_{2}\right)$ e, por meio de uma tomada de posição, criar um distanciamento, o sujeito da enunciação desloca sua identificação para uma outra formação discursiva que, de nossa ótica, funciona como um retorno à posição de aluno, que designamos por $\mathrm{E}_{4}$ por não se tratar de uma voz coincidente com $\mathrm{E}_{1}$, em virtude do percurso que acabamos de relatar. Convém salientar, também, a coesão 
referencial pela pró-forma pronominal "elas" que entendemos como um (re)posicionamento ou uma tentativa de (re)identificação da forma-sujeito aluno que então enuncia: "poxa... isso aí ta sendo passado... mas o que tem por trás disso?” sabe, “e... que que isso interfere... sei lá... na economia... na política... na sociedade?” Encerrando esse movimento, portanto, A5, volta a empregar o substantivo pronominalizado "a gente" e, finalmente, "eu”, acomodando-se, então, a uma forma-sujeito que, nesse contexto, poderíamos chamar de "original" $\left(\mathrm{E}_{1}\right)$.

Antes de ponderarmos sobre os efeitos dessa tomada de posição no discurso de A5, bem como sobre as implicações para nossa investigação, passemos para outro momento, no qual a questão do curso e da formação são abordados.

Excerto 9 A5: [...] como é que você quer abordar tudo isso... em dois anos? ... porque... na realidade... ta... o curso é de três anos... mas a gente tem literatura só em dois... então eu acho isso um crime... eu acho... pavoroso... sabe... eu acho que::.: ... isso... é lógico... ta... eu entendo do ponto de vista... da faculdade... porque::: no mercado... hoje em dia... tem esses DITOS cursos superiores de dois anos... que também é um outro crime... que eu acho que o MEC não deveria autorizar isso e::. ... esses cursos... eles... é lógico... acabam éh... oferecendo uma coisa... muito competitiva... porque para um cara que quer só o diploma (então ele) é muito conveniente... ele ir em um curso de dois anos e adquirir o seu diploma... ele não vai querer fazer uma faculdade... então as faculdades... cada vez mais... elas tão mi/mixando tudo pra comportar em três anos... só que... por um lado... por exemplo... pra mim... que::.: ... viso aprender realmente... e quero adquirir conhecimento... é terrível ((exclamou)) ... porque eu vejo muita coisa sendo abandonada e tem que ser abandonada por causa de tempo...

Observamos que, nesse momento, A5 resgata em seu discurso um "você", que conforme já indicamos, ocupa o lugar de professor alocutário "imaginado" $\left(\mathrm{E}_{3}\right)$ para referir-se à aplicação do conteúdo. Reparemos na seqüência intercalada que revela diferentes vozes que perpassam por A5, marcada por expressões modalizadoras em seu discurso. Dessa forma, temos o seguinte esquema: $E_{1}$ marca no seu dizer, por meio da entonação, uma modalidade de frase interrogativa, que figura como um postulado autoritário, requerendo ou implicando o interlocutor (professor-pesquisador) em uma atitude responsiva, seja de engajamento, anuência, adesão, que vem marcado por um caráter de dubiedade ao empregar a referência dêitica pronominal "você". No entanto, em seguida, A5 ameniza esse efeito autoritário do seu ato ilocucionário ${ }^{93}$ por meio do modalizador "na realidade" e do marcador fático "ta", introduzindo uma "justificativa" (voz institucional) para sua pergunta, que nomeamos ainda

93 Conforme Austin (1962/1990, p. 95), "atos ilocucionários" são "proferimentos que têm uma certa força (convencional)", tais como: informar, ordenar, prevenir, avisar, entre outros. 
como um "locutor coletivo" " 94 . No entanto, no encadeamento seguinte, por meio da conjunção adversativa "mas" retoma a postura de engajamento, formulada anteriormente por meio da sentença interrogativa, manifestando uma crítica a partir da perspectiva de $\mathrm{E}_{1}$ (a gente) para, em seguida, modalizar novamente sua carga asseverativa ("é lógico... ta... eu entendo") que reintroduz a voz de um "locutor coletivo" marcada explicitamente pela expressão "do ponto de vista... da faculdade" e pelo encadeamento iniciado pela conjunção explicativa "porque".

A partir de então, A5 (locutor "responsável" pelo dizer) inicia um jogo polifônico, entre dois locutores (explícitos ou não) responsáveis por formulações que se intercalam e colocam em cena dois enunciadores, que podemos definir como locutor-aluno A5 (perspectiva de $\mathrm{E}_{1}$ ) e um locutor coletivo (perspectiva institucional: faculdade, MEC), uma voz, portanto, representativa de um grupo que se mostra diluído entre várias instâncias não identificadas. Para melhor visualização desse jogo polifônico, resumimos as formulações no esquema seguinte $^{95}$ :

\begin{tabular}{ccc}
\hline $\begin{array}{c}\text { LOCUTOR COLETIVO } \\
\text { (instituição, faculdade, mercado, } \\
\text { MEC) }\end{array}$ & $\leftrightarrow$ & $\begin{array}{c}\text { LOCUTOR A5 } \\
\text { (perspectiva de E } 1 \text { ) }\end{array}$ \\
\hline $\begin{array}{c}\text { "o curso é de três anos" } \\
\text { "existem cursos superiores de dois } \\
\text { anos" }\end{array}$ & $\leftrightarrow$ & $\begin{array}{c}\text { "é outro crime }[\ldots] \text { não deveria ser } \\
\text { autorizado" }\end{array}$ \\
$\begin{array}{c}\text { "esses cursos oferecem uma coisa } \\
\text { muito competitiva }[\ldots] \text { são } \\
\text { convenientes" }\end{array}$ & $\leftrightarrow$ & $\begin{array}{c}\text { "é terrível" } \\
\text { "o conteúdo dos cursos deve ser } \\
\text { ministrado em três anos" }\end{array}$ \\
\hline
\end{tabular}

Para a reflexão que estamos propondo neste trabalho, é de suma importância, portanto, perceber a diluição de $\mathrm{E}_{1}$, nas diversas locuções enunciadas, revelando, dessa forma a partição de A5. Deduzimos, a partir dos excertos 7, 8 e 9 analisados, que, conforme vimos apontando, a “dispersão do sujeito", nas palavras de Orlandi (2001, p. 53), nos auxilia a considerar que a heterogeneidade de vozes no discurso de A5 gera um efeito de indeterminação e indefinição

\footnotetext{
94 Segundo Charaudeau e Maingueneau (2004, p. 311), essa expressão é usada para designar os autores dos discursos advindos de partidos, sindicatos ou outros grupos organizados que sejam representativos (textos de congressos, moções, resoluções diversas).

95 Esclarecemos que adaptamos algumas sentenças para transcrevê-las no esquema por julgarmos serem mais representativas dos enunciadores em questão.
} 
das subjetividades (do aluno e do professor), assim como da noção de formação de professores de inglês.

Reiterando o que vimos na análise desses excertos, quanto ao perfil do aluno, pudemos detectar, primeiramente, uma identificação com o papel do professor, a rejeição de algumas características "não apropriadas" para um professor "ideal", para em seguida, articular sobre a questão da formação e do seu preparo profissional, mostrando, por meio de um jogo polifônico, uma fragmentação que busca compartilhar com seu interlocutor (professorpesquisador). Ou seja, ao mesmo tempo que questões de conteúdo (currículo) são criticadas, há, de maneira implícita, uma aceitação (submissão) por parte de A5 às condições impostas pelo contexto institucional e mercadológico. Desse modo, A5 sinaliza um tipo de interação de caráter confessional com o interlocutor (professor-pesquisador). Lembramos, aqui, sua sugestão, trazida em outro momento da enunciação, para que a Instituição 1 criasse uma escola-modelo, fornecendo cursos à comunidade. Tais cursos poderiam ser ministrados pelos alunos de licenciatura que teriam "na prática"96 a vivência necessária para a docência ainda dentro da universidade, tendo, desse modo, a chance de serem supervisionados pelos próprios professores-formadores que trabalham na sua formação. Para A5, isso tornaria os alunos mais “competentes e preparados" para a carreira docente.

Buscando ler ou, nas palavras de Pêcheux (2002, p. 44), ““entender' a presença de não-ditos no interior do que é dito", temos, no discurso, formulação que nos leva a compreender que a preparação do aluno para a carreira docente não ocorreu conforme "modelo ideal" construído e colocado à distância pelo funcionamento discursivo apresentado. Cabe, ainda, destacar uma formulação trazida no excerto 8 que diz respeito à transformação de "pessoas em seres humanos completos". Nesse imaginário discursivo, identificamos aquilo que Mascia (2002, p. 18) analisou como "ideário de progresso", ou seja, uma visão educacional pautada nos ideais da modernidade ou na crença de que, com a educação e o trabalho, obtém-se uma melhoria do indivíduo e da sociedade.

\subsection{Modos de constituição de um pacto tácito sobre a formação}

\footnotetext{
${ }^{96}$ Esse aspecto será retomado mais adiante na análise.
} 
Quanto ao caráter confessional que acabamos de mencionar, cabe justificar como ele é obtido. Lembremos, para tal propósito, a teoria bakhtiniana dos gêneros do discurso. Para Bakhtin (2003, 1929/2004), não se pode prescindir dos aspectos discursivos e interacionais da linguagem. Esse lingüista russo entende que o texto é resultado de uma interação social. É por meio dele que formula a noção de gêneros do discurso como sendo os diversos modos de funcionamento da linguagem, com conteúdos e características lingüísticas próprias vinculadas a tais modos e aos usos que se faz da linguagem. Para os propósitos deste trabalho, o fato de estarmos diante do gênero "entrevista" instiga algumas ponderações.

Maingueneau (1998/2004, p. 87) amplia essa discussão sobre os gêneros do discurso criando o conceito de cenografia para indicar uma relação na qual o enunciado é legitimado pela própria enunciação: "a cenografia é ao mesmo tempo a fonte do discurso e aquilo que ele engendra". Conforme o lingüista, a cena de enunciação, portanto, envolve um quadro que apresenta uma cena genérica (entrevista, no nosso caso), inserida em uma cena englobante (pesquisa científica, idem). Ou seja, para nossos interesses, a cenografia é um fator relevante que propicia a construção de uma interlocução, na qual se cria uma relação pactual de confidência, de cumplicidade entre os "atores" da cena enunciativa (alunos ou professoresformadores/professor-pesquisador). Com isso, a enunciação torna-se inteligível em função dessa conjunção de elementos. A mobilização de tal conceito deve-se ao fato de entendermos que certos fragmentos enunciativos "fazem sentido" por serem compreendidos, socializados, compartilhados entre alunos e professores-formadores da Instituição 1, no ato da entrevista. ${ }^{97}$

Reiteramos que vimos explorando o discurso por meio de categorias (polifonia enunciativa, negação, narrativização) que, sob nosso ponto de vista, se constituem em uma malha basilar, a partir da qual capturamos marcas que apontam para uma ambivalência constitutiva. Nesta dimensão, notamos que ela ocorre por meio da diluição dos sentidos sobre a questão da formação de professores de inglês. Com isso, vemos no funcionamento discursivo um dizer que se torna impossível de ser expresso. No entanto, esse dizer, de alguma forma, se apresenta com efeito camuflado e compartilhado entre os sujeitos desse discurso. Deste momento em diante, passamos a enfatizar sinais no discurso que sugerem uma

\footnotetext{
${ }^{97}$ Lembramos trabalho de Guirado (2000) que mobiliza o conceito de cena genérica e cenografia ao investigar pontos de articulação entre a $\mathrm{AD}$ e a clínica psicanalítica. Sintetizamos como, para a autora, a $\mathrm{AD}$ pode influenciar de três maneiras o trabalho clínico. Primeiramente, na compreensão das terapias ou análises como práticas discursivas. A segunda contribuição diz respeito à mudança de perspectiva que noções como discurso e enunciação imprimem ao ato analítico. Finalmente, a AD influencia a clínica psicanalítica ao trazer à baila a noção da não-transparência do discurso, assim como da sua heterogeneidade constitutiva.
} 
situação de caráter condicionante, lasso e ambíguo na formação. Postulamos que, por meio de tais momentos, esse "dizer impossível" se mostra, delineando, de forma tácita, um pacto sobre a impossibilidade da formação mediante determinadas condições. Identificamos que tal pacto tácito esboça-se em diferentes instâncias. Voltemos nossa atenção, agora, para o afloramento de tais sinais no discurso que, somados, ao final da análise, insinuam a constituição de um pacto tácito sobre a impossibilidade da formação.

As formulações que exploramos, a seguir, abordam aspectos ligados ao preparo e à profissionalização do futuro professor de inglês, atividades docentes, expectativas com relação ao mercado de trabalho e outras questões similares. Vejamos o excerto:

Excerto 10 P5: [...] a gente tem alguns alunos que são assim extremamente compromissados... eu acho que esses vão pra frente... são aqueles que vão atrás... que... que te procuram pra tirar dúvida... que te procuram pra te pedir material extra... que... que sempre têm interesse em participar... em fazer... em aprender e que você sabe que quando eles saírem daqui eles não vão se acomodar... a gente tem um número razoável de alunos assim... em compensação temos outros assim que... ou por falta de base... né? ou por falta de interesse são pessoas que vão se arrastando assim pelo curso e... eu acredito que... na área de inglês... não vão se desenvolver muito... mas tem um bom número assim que que tem potencial e que... que eu acho que vão deslanchar... eles vão sair daqui... com condição de... de... se aprimorar e de encarar o mercado de trabalho...

Ao fazer referência ao futuro desse aluno, P5 elabora uma divisão em dois grupos, definindo o primeiro, como "compromissados" e criando, para o segundo ("em compensação temos outros assim que...") uma interdição, um "silêncio local”, conforme propõe Orlandi (1997, p. 108). Em outras palavras, há uma formulação possível para esse segundo grupo, criada - mas não enunciada -, suscitando um compartilhamento do professor-pesquisador para o silenciamento por meio da pausa e do marcador conversacional "né". No que diz respeito ao primeiro grupo, identificamos uma formação discursiva do senso comum expressa pelo verbo "ir" no presente do indicativo seguido da expressão "pra frente", que pode ser vista como representativa de um desejo sacralizado pela busca de sucesso. Imbuído em tal enunciado, de nossa ótica, está o ideal de uma realização pessoal e profissional que tem suas raízes no projeto iluminista. Nesse trecho, identificamos, novamente, um momento de conflito do professor-formador em face da diversidade e da incerteza trazida pela história pessoal dos alunos, uma vez que eles não estão "maduros" para a vida universitária. Do nosso ponto de vista, tal aspecto demonstra o "não-cumprimento" de um projeto moderno de educação. Essa 
"falta de base" deve ser "resgatada" pelo professor-formador? Além desse "resgate", o professor-formador também se confronta com a necessidade e a urgência de preparar o aluno (futuro professor de inglês) para sua inserção no mercado de trabalho.

A fim de destacar o aspecto condicionante, lasso, ambíguo que mencionamos acima, observemos como a construção subjuntiva expressa com o verbo "sair", juntamente com a formulação seguinte que emprega o verbo opinativo "achar" revelam esse efeito de sentido (“eu acho que vão deslanchar... eles vão sair daqui... com condição de... de... se aprimorar e de encarar o mercado de trabalho...”). Há de se observar, ainda, a utilização dos verbos "deslanchar" e "aprimorar" cujo campo semântico se aproxima da expressão "ir para frente", visto anteriormente. Quanto ao fato de poder "encarar o mercado de trabalho", isso está intimamente condicionado ao aprimoramento do aluno. Diante desse fragmento, compreendemos que a ambigüidade provocada pelo silenciamento, a debilidade da divisão dos grupos e a impossibilidade de uniformização de interesses e saberes desestabilizam a atitude do professor-formador. Essa desestabilização gera conflitos que põem em xeque sua visão educacional, seu papel, sua subjetividade, enfim. Somos da opinião de que, no bojo desse conflito, figura o embate das certezas modernistas com a flexibilização, a amplitude dos sentidos, ou seja, traços que a pós-modernidade faz despontar.

No que tange ao silenciamento, acima destacado, cabe trazer de volta para a discussão a teoria dos gêneros do discurso. Dissemos que estamos diante do gênero entrevista e que, portanto, a cena enunciativa propicia uma atmosfera de confidência, cujos fragmentos ali enunciados tornam-se compartilhados, compreendidos, anuídos pelos interlocutores (aluno/professor-pesquisador ou professor-formador/professor-pesquisador). O modo como a linguagem é colocada em funcionamento no gênero entrevista "interpela"98 os participantes da cena enunciativa (alunos, professores-formadores e, sobretudo, o professor-pesquisador) em sujeitos conhecedores ou legitimadores das reproduções de vozes (do aluno ou do professorformador) ou, no caso acima, dos "sentidos" que são postos em silêncio. Com isso, cria-se no discurso de P5 um momento de pausa, no qual se espera do professor-pesquisador uma atitude responsiva de anuência, de compreensão acerca do dizer que foi silenciado. Logo, o silenciamento compartilhado e, por conseguinte, legitimado entre os participantes da cena

\footnotetext{
${ }^{98}$ Nesse e nos demais casos em que o termo é empregado, baseamo-nos na noção pecheutiana de interpelação do sujeito.
} 
enunciativa traz para o discurso um efeito de cumplicidade que evidencia a constituição tácita de um pacto, nesse caso, entre professor-formador e professor-pesquisador.

Examinemos uma outra instância de ocorrência do pacto tácito: aluno e aluno(s). Vejamos o excerto a seguir:

Excerto 11 A1: [...] na parte de inglês eu acho que não::: não foi legal... eu já sou formada pelo ((citou escola de idioma))... e o que eu vi aqui não foi nada diferente do que eu já tinha visto... [...] eu to saindo assim ainda meio insegura do curso... [...] eu acho que eu to bem preparada na parte de inglês... mas não pelo curso da ((citou instituição 1)) pelo curso que eu já tive... [...] e a gente já tem esse estereótipo... os próprios alunos de letras ahn... a gente já tem esse... a gente criou mesmo esse estereótipo de "ah não o curso de letras não é legal aqui"...

Notamos, no excerto acima, a inclusão do substantivo pronominalizado "a gente" que revela um processo dialético para sustentação da argumentação de A1. Tal indicação nos leva a concluir que A1 se vê autorizado a enunciar julgamento sobre a Instituição 1, pois tal formulação já foi elaborada juntamente com outros alunos. Essa inferência é possível a partir do verbo no passado perfeito (criou) e pelo emprego da palavra "estereótipo"; ou seja, houve a "fixação" temporária de um sentido. Há de se destacar também a presença dos advérbios "já" e "mesmo" que reforçam sua argumentação. Ao expressar sua "própria"99 opinião, A1 declara, ainda, que sua formação com relação à língua-alvo já ocorrera em outro local (“já sou formada pelo...”), sugerindo, portanto, que o mesmo não ocorre em relação à sua preparação profissional, o que vem marcado pelo advérbio "ainda", seguido do adjetivo "insegura".

Convém notar que a presença desse advérbio sugere uma pressuposição, que, segundo Kerbrat-Orecchioni (1986), é uma informação que não está posta de maneira clara; ou seja, o aluno revela que o estado de insegurança já existia anteriormente, e, especialmente, que ele persiste em um momento no qual já não era mais esperado (segundo pressuposto decorrente). Temos, desse modo, formulações que remetem aos dizeres dos professores-formadores (seção anterior) quanto à falta de preparo para a vida profissional. No caso do excerto 11, parte dessa preparação ocorrera em outro local. Podemos afirmar que esse excerto esboça a constituição do que estamos chamando de pacto tácito, nesta instância, entre alunos. Nela, há uma formulação que sugere a debilidade do curso de formação, noção criada entre os alunos, no dizer de A1. No entanto, não se esboça nem um tipo de ruptura com o vínculo

\footnotetext{
${ }^{99} \mathrm{O}$ emprego das aspas refere-se à ilusão do sujeito de ser origem do seu dizer, segundo Pêcheux (1997b).
} 
aluno/instituição, mesmo tendo tal estado de insegurança existido durante todo o curso. O fato de esse vínculo não ser rompido leva-nos a conceber a constituição de uma condição pactuária, na qual ambas as partes se beneficiam mutuamente.

No excerto que se segue, voltamos a identificar, conforme vimos no excerto 11, reprodução de vozes do(s) aluno(s), provocando um efeito de legitimação no discurso. Do ponto de vista enunciativo, há um jogo polifônico, eminentemente, híbrido ${ }^{100}$, a ponto de criar uma absorção díspar de vozes, por isso o efeito de legitimidade no discurso. Podemos afirmar que tal característica propicia o apagamento da voz do sujeito, ou ainda funciona como mecanismo de "dizer sem se comprometer", de acordo com Fiorin (2002/2006, p. 184). Vejamos, então, o excerto:

Excerto 12 A3: olha eu não sei... se é da ((citou instituição 1))... como funciona mas a gente sente muita falta não sou só eu a turma como um todo né a gente sente muita falta... do que a gente vai dar de matéria porque a gente tem matéria... a gente tem o conteúdo... a gente sabe o conteúdo... mas a gente não sabe dar aula... então por ser formação de professores... não sei também se é porque é segundo ano no terceiro ano a gente tem mais a parte mais prática... mas a gente sente falta disso... a gente... ta:.: ((pausa longa)) "... mas o que a gente vai dar de aula? ... como é dar essa aula? ... ta bom a gente tem o conteúdo aqui... mas... pra que série isso vai?" ... né... de... ter essas/algumas informações assim... apesar de eu achar que assim muita coisa ainda vem no ano que vem... que vai... dar suporte pra isso tem muita... desde o começo do ano que a gente espera mais aquela coisa focada "vamos dar aula então o que vamos fazer... o que é dar aula? né...o que a gente precisa passar pro aluno?" [...] porque tem gente que fala "você é professor você dá aula de qualquer coisa se você tiver o conhecimento daquele conteúdo você dá aula... porque você SABE DAR AULA" então às vezes eu sinto um pouco... falta disso... principalmente porque a gente vai pro estágio agora né? e vai pras aulas de regência a gente ta perdido porque a gente fala "como que é preparar uma aula? ... o que que é preparar uma aula? o que que a gente faz né que... se baseando em quê essa matéria é pra essa série... e não pra outra isso é muito difícil isso é muito fácil né..." então assim às vezes eu sinto um pouco de falta disso... dessa idéia assim... "o que fazer pra... como é dar aula?" ((risos)) né de ter um pouco de bagagem né eu acho que isso vem também... que é um pouco do tempo né se vai... conforme se vai dando aula se vai... pegando a prática de planejar de saber a turma de identificar... mas assim... dá::: um pouco de medo porque a gente vai pra situação de sala de aula... sem esse certo preparo né...

Com a exposição desse fragmento, examinemos, primeiramente, como esse sujeito compõe as diversas vozes que mencionamos acima. O sujeito constrói sua argumentação

\footnotetext{
${ }^{100}$ Empregamos esse termo como uma tradução do conceito de "Hibridity", elaborado por Bhabha (2007) que, nesse contexto, designa uma coexistência simultânea de enunciados fragmentados que ajudam a compor um painel do aluno, mas mantendo uma origem conhecida ou socializada entre entrevistado e entrevistador.
} 
recorrendo a diferentes enunciadores: "a gente", "a turma", "nós" (sujeito elíptico em "vamos") e, finalmente, "eu". Dessa forma, a responsabilidade pela formulação torna-se velada, imprimindo ao seu conteúdo, em virtude da disseminação de sujeitos da enunciação, um estatuto de uma verdade abrangente, pois a totalidade da fala está assim socializada, dividida, compartilhada entre os diversos "responsáveis" pelos dizeres. Notamos uma conduta expectante causada pelo uso da palavra "falta", em diversos momentos da enunciação, compartilhada entre diversos "enunciadores".

Da posição de locutor, A3 passa para a posição de alocutário, marcado explicitamente pelo pronome "você" (porque tem gente que fala "você é professor você dá aula de qualquer coisa se você tiver o conhecimento daquele conteúdo você dá aula... porque você SABE DAR AULA"). A inclusão de uma terceira voz subjetivada "tem gente que fala", "exterior" à enunciação, torna o discurso ainda mais velado, há a inclusão de uma voz outra, cuja autoria é desconhecida e acaba por produzir um efeito de diluição no discurso, produzindo, conforme aponta Maingueneau (2004, p. 133), “uma espécie de apagamento das fronteiras entre as posições de primeira, segunda e terceira pessoas." Em outras palavras, o sujeito circula entre dizeres, construindo de forma dialógica uma sustentação no discurso e revelando a existência de múltiplos fluxos de idéias que se associam e acabam por mostrar um abafamento desse sujeito, pois ele se dilui nas diversas instâncias enunciativas.

Com esse efeito, então, inferimos a existência de uma voz que, embora diluída, apresenta-se compactuada com vozes diversas que são trazidas para a enunciação. Podemos observar, a partir das formulações de A3, a presença de um desdobramento do pacto tácito. Primeiramente, a repetição da expressão "a gente" nos faz supor que a instância primeira seria aluno/aluno(s). Em seguida, a mesma expressão assume uma dimensão mais coletiva, externa, uma voz "social" que traz para o discurso uma noção linear sobre ensino, de causa e efeito (basta ser professor para dar aula de "qualquer coisa"). Ao ser perpassado por tal formação discursiva, o sujeito estabelece uma relação de conformidade com esse dizer, um pacto, portanto entre aluno e um "enunciador-genérico"101 , pois resgata uma formulação cristalizada do senso comum.

${ }^{101}$ Guimarães $(2005$, p. 25) propõe tal designação para indicar o enunciador que se mostra "dizendo com todos os outros", isto é, não se trata de um lugar individual, mas de uma perspectiva ocupada por qualquer outro enunciador para, por exemplo, repetir um dito popular. 
Outro aspecto que é igualmente pertinente salientar diz respeito à série de perguntas retóricas formuladas (“o que a gente vai dar de aula?”, “como é dar essa aula?”, "pra que série isso vai?"). Podemos lembrar, novamente, a contribuição de Austin (1990, p. 95) sobre os atos ilocucionários para refletirmos sobre tais questões. Segundo esse filósofo da linguagem, há "proferimentos que têm uma certa força (convencional)", isto é, podemos dizer que implicam, envolvem o alocutário. No que diz respeito à enunciação acima descrita, concluímos que A3, conforme vimos, anteriormente, de locutor, foi interpelado como alocutário. Nos questionamentos, assume novamente a posição de locutor, interpelando, por conseguinte, o professor-pesquisador, pela força do ato ilocucionário, em alocutário (você), pois, na qualidade de professor-formador da Instituição 1, teria condições de atender ao pedido expresso em forma de sentenças interrogativas. Entendemos que tais questões, embora retóricas, são carregadas de incertezas que são "transferidas" para o alocutário (professorpesquisador) ao envolvê-lo no ato ilocucionário. A atitude "não responsiva" do professorpesquisador, inerente ao gênero entrevista, cria um efeito de concordância, de acordo tácito com as dúvidas e questões levantadas por A3. Fato que, seguindo nossa linha de raciocínio, constitui-se, novamente, em um pacto. Nessa instância, entre aluno e professor-pesquisador.

Observemos, no mesmo excerto 12, que, quando a questão do perfil profissional futuro desse sujeito é mencionada, há no discurso um efeito de compartilhamento, de anuência em: "apesar de eu achar que assim muita coisa ainda vem no ano que vem eu acho que isso vem também... que é um pouco do tempo né se vai...” Do ponto de vista da materialidade lingüística, ao mesmo tempo que aparecem críticas em relação ao curso, ao conteúdo, enfim, por meio do encadeamento com a locução concessiva "apesar de", a crítica é amenizada, pois essa "falta" que foi mencionada anteriormente será preenchida com o tempo (elemento outro). Há que se atentar também para a coincidência de vozes em: “conforme se vai dando aula se vai... pegando a prática de planejar de saber a turma de identificar". Introduzido por uma conjunção conformativa que sinaliza, portanto, uma circunstância de conformidade, de acordo, pactual. Esse encadeamento remete a uma formação discursiva que poderíamos classificar como discurso da prática pedagógica, que, conforme analisou Bertoldo (2003), cria uma dicotomia entre teoria e prática na formação de professores.

Em outro momento da enunciação, apresentada no excerto 13, há formulações que, conforme vimos detectando, mostram um caráter provisional da formação. 
Excerto 13 A3: [...] no resto eu acho que a gente tem um curso muito produtivo apesar do pouco espaço de tempo mas... você percebe que depende muito mais do aluno não do professor... pelo menos eu vejo isso não só por mim mas até mesmo comparando com outros alunos ou entre professores assim você percebe que depende muito pouco... deles depende muito mais de nós alunos assim... porque eles vão lá e eles passam e ainda fica na condição né "a gente ta passando... é um pouco... porque a gente não tem tempo" ((risos)) porque tem sempre o problema do tempo né... não sei se isso... porque por outro lado a gente tem que buscar muito mais... por fora né e aí no final você... tá tendo uma formação... mas ela é meio por conta própria você tem que se empenhar muito mais... né

Do ponto de vista argumentativo, no primeiro encadeamento da formulação, o conector argumentativo "mas" enfraquece a primeira proposição ("curso produtivo apesar do pouco espaço de tempo"), transferindo maior força argumentativa para a conclusão que se segue ("depende muito mais do aluno"). A inclusão de depoimentos originados de "outros alunos" ou "entre professores" provoca um efeito de respaldo à enunciação. Isso nos faz ver a presença de duas instâncias de ocorrência do pacto sobre a formação. Tanto na primeira, aluno/aluno ("outros alunos") como, na segunda, professor-formador/professor-formador (“entre professores”), há um sentido disseminado de que a "formação" está a cargo do aluno. Reparemos o efeito do uso da preposição "entre" funcionando como um argumento de autoridade, que relata uma voz genérica, permitindo ao sujeito silenciar sua inquietação, pois essa voz funciona como elemento confirmador de que a formação (objeto que se busca) está a cargo do próprio aluno. Há um efeito de justificação no dizer de A3 por meio do encadeamento da conjunção causal "porque”. Para Brandão (1998, p. 117), essa seqüência iniciada com tal conjunção faz com que o enunciador se veja engajado nessa relação de justificação. Percebemos um efeito de isenção da responsabilidade dos professoresformadores, agora como protagonistas delocutários: "eles" (excluindo, dessa forma, a interpelação do professor-pesquisador), pois as ações são realizadas dentro das condições possíveis. Há, portanto, uma anuência desse aluno de que o vínculo estabelecido com esse professor-formador é temporário e compartilhado, pois essa relação, conforme sugere Bauman (2005, p. 37), existe na aparência enquanto há um compromisso para perdurar. ${ }^{102}$

Voltando à materialidade da língua, atentemos para outros encadeamentos, nessa seqüência, que sugerem essa cumplicidade dialética na relação aluno/professor-formador. $\mathrm{O}$ primeiro, também marcado pela conjunção "porque", ocorre por meio da reprodução da voz

${ }^{102}$ Bauman cunha a expressão "comunidades guarda-roupa" para designar a transitoriedade de certos tipos de relações pessoais que congregam indivíduos em torno de uma questão inusitada, de uma dificuldade ou problema, mas, são rapidamente desfeitas quando a necessidade que os juntou deixar de existir. 
do professor-formador em uma outra situação de enunciação ("a gente ta passando... é um pouco... porque a gente não tem tempo"), no entanto, ao abandonar a posição desse outro enunciador, A3 volta a enunciar da perspectiva do aluno, justificando o argumento empregado e assumindo que a formação depende, em última análise, do empenho de cada aluno. No segundo, novamente encadeado pela conjunção "mas", o sujeito ressalta a importância da sua segunda proposição, diminuindo o valor da proposição anterior ("você... tá tendo uma formação... mas ela é meio por conta própria”).

Resumindo as considerações propostas a partir dos excertos 12 e 13, compreendemos que o jogo dialético mostrado pelo sujeito aponta novamente para marcas de heterogeneidade no discurso e, sobretudo, que essas marcas, acrescidas de encadeamentos, ora concessivos, ora justificativos, criam um movimento contraditório na argumentação que torna o discurso difuso por meio da pulverização de diferentes vozes, em diferentes momentos da enunciação, que revelam conexões, ou manobras argumentativas (não intencionais) de convencimento mútuo, de compartilhamento de opiniões entre os protagonistas da enunciação. A existência dessas múltiplas vozes, especialmente as intercalações com a voz do professor-formador, produzem um efeito de leniência por parte do aluno, ou seja, ele parece compreender que sua formação é provisória. Desse modo, essa compreensão nos leva a reforçar a existência do acordo tácito sobre a interinidade da formação diante das circunstâncias mencionadas (tempo escasso, volume do conteúdo, falta de preparo etc.).

No excerto 14, trazemos ainda a questão da qualificação do aluno, no qual o ponto de partida da argumentação é a reprodução da voz de um colega de turma. A instância do pacto tácito dá-se, desse modo, entre aluno/aluno.

Excerto 14 A4: [...] eu vejo os alunos que nem o ((citou colega de turma)) que ta dando aula EFETIVAMENTE na escola ele fala/fala "gente... o que a gente ouve em didática... em prática pedagógica" ele falou... "sabe o que que é você pegar... o preto... você chega lá na escola é branco... isso que eles falam aqui na escola... pra mim... entra por um ouvido e sai por outro... porque a realidade... é outra... não existe nada disso que a gente aprende aqui”... então é isso que eu penso... [...] a gente percebe que é assim... e o tempo que a gente tem de curso não é suficiente pra aprender tudo aquilo que a gente... precisa né... mesmo que seja só a base porque a gente sabe que a gente não vai sair daqui com todo o conteúdo gramatical de... tanto de português quanto inglês... que isso é uma coisa que a gente vai ter que pesquisar... que a gente vai ter que aperfeiçoar quando for dar aula... né... 
Como pudemos notar, A4, na posição de locutor que classificaremos como $E_{1}$, introduz a voz de um enunciador $\mathrm{E}_{2}$, imprimindo no discurso um caráter de veracidade por meio da adverbialização (efetivamente). Do ponto de vista da enunciação, a formulação reproduzida revela marcas de ambigüidade que vêm expressas pelo uso do pronome "você". A reflexão de Benveniste (1966/1995) sobre a estrutura das relações de pessoa no verbo nos permite identificar a presença de uma forma que o autor classificou como inclusiva (eu + vós). Isto é, temos a reprodução de uma cena, na qual esse $E_{2}$ interpela $E_{1}$, não mais como colega de turma, mas como futuro profissional, alertando-o sobre um panorama que difere totalmente do conteúdo visto durante o curso, relação que se mostra dicotômica e expressa pelo jogo antonímico dos adjetivos "preto/branco". Em seguida, $E_{2}$ iguala-se a $E_{1}$ em uma "correlação de subjetividade", conforme postulado por Benveniste (p. 257), marcada pela pronominalização na expressão "a gente". Essa oscilação enunciativa, conforme vimos também nos excertos 12 e 13, ajuda a construir uma argumentação que classificamos de referendada (por um outro autorizado). Diferentemente dos excertos 12 e 13, nos quais vimos a pulverização de vozes para dizer, no excerto 14, o dizer é partilhado entre os enunciadores $\left(E_{1}+E_{2}\right)$. Ao incluir a voz de $E_{2}$ no momento da enunciação, $E_{1}$ se molda ao seu dizer, comungando, dessa forma, da mesma opinião de $\mathrm{E}_{1}$. Daí o efeito do pacto na instância aluno/aluno.

Outro aspecto que gostaríamos de salientar, no excerto 14, trata da questão da formação, que parece estar pautada em fatores muito mais de nível conteudístico do que didático-pedagógico. Há novamente a menção da duração do curso, mas, no entanto, quanto a esse aspecto, não há evidências que denotem uma queixa, uma crítica. Pelo contrário, o sujeito parece estar ciente de que sua preparação/formação ocorrerá em um outro momento e local. Atente-se para o uso do verbo "saber" no presente do indicativo. Retomando contribuição de Weinrich (1974) sobre a função dos tempos verbais no discurso, vemos na formulação: "a gente sabe que a gente não vai sair daqui com todo o conteúdo gramatical de... tanto de português quanto inglês..." uma atitude comprometida de que nos fala o autor, sugerida por meio da forma verbal que expressa um "mundo comentado": "a gente sabe".

Outra característica do uso dos tempos verbais "comentadores" é criar uma tensão no discurso por promover a implicação do ouvinte, nesse caso, representado pelo professorpesquisador que, conforme já alertamos em momento anterior, faz parte do grupo de professores-formadores da Instituição 1. Atente-se também para o emprego do dêitico "daqui" 
que revela, mais uma vez, características que temos tentado demonstrar com relação à situação pactuante, de maneira implícita, entre A4 (aluno) e seu alocutário (professorpesquisador) interpelado, nesse momento, como figura institucional. Na cadeia discursiva, notamos também um efeito de compreensão com relação à necessidade de manter ou continuar buscando a formação em outro lugar, exterior ao contexto da enunciação. Para melhor esclarecimento, observemos o nível de comprometimento expresso por meio da locução verbal "vai ter", seguida de dois infinitivos ligados pelo pronome relativo "que" para enfatizar o dizer.

A respeito da locução verbal, retornemos ao estudo de Weinrich (1974, p. 347) que cunha a expressão "semitempo" para qualificar os modos subjuntivo, imperativo, infinitivo, gerúndio e particípio. ${ }^{103}$ Segundo ele, essas formas verbais vêm sempre ligadas a um outro tempo mais significativo dentro de um período, anterior ou posterior a elas. Partindo dessa análise, Koch (1984/2002, p. 41) postula que o emprego do perfeito composto pode ser considerado "como momento narrativo dentro do comentário" que acrescenta um argumento ou exemplificação em forma de um relato. Julgamos que a perífrase verbal empregada ("vai sair", "vai ter") é um exemplo ilustrativo dessa análise, pois em todos os casos ("a gente não vai sair daqui com todo o conteúdo gramatical", "a gente vai ter que pesquisar", "a gente vai ter que aperfeiçoar") estão em relação de dependência com um dizer anterior de maior expressividade (“a gente sabe que”).

Vemos, dessa forma, novamente, a construção do perfil desse aluno de maneira narrativizada, conforme já apontamos anteriormente. Essas construções verbais empregadas criam um efeito lacunar no discurso, ou seja, recorrendo a formulações que revelam uma relação de dependência ao serem expressas por diferentes enunciadores: "a gente", "eu", "você" $\left(E_{1}\right)$, "você" $\left(E_{1}+E_{2}\right)$, ou ainda por "ilhas enunciativas"104. Apontamos, portanto, que esses fatores deixam marcas no discurso que revelam uma situação flutuante na qual tanto a constituição desse sujeito, bem como a narrativização de uma situação futura, estão à espera

\footnotetext{
${ }^{103}$ Sobre a contribuição de Weinrich na AD, julgamos oportuno citar também os trabalhos de Coracini (1991) e Brandão (1998), mencionados anteriormente.

${ }^{104}$ Maingueneau (2004, p. 151) utiliza tal expressão para fazer referência a um determinado fragmento destacado por aspas ou itálico, numa enunciação, indicando que ele "provém" de um outro enunciador. Porém, tal fragmento está "perfeitamente integrado à sintaxe: só a tipografia permite verificar que essa parte do texto não é assumida pelo relator".
} 
de um momento de basteamento ${ }^{105}$, de fixação de um sentido. Enfim, há a busca por um momento, um ato de enunciação que encerre, forneça um "ponto de basta" a uma cadeia de significantes; nesse caso, pode ser expresso pela busca de uma significação de natureza identitária, formativa ou profissional. Vale ainda salientar que, nesses momentos, conforme já destacamos, há sempre a interpelação do professor-pesquisador como parte integrante desse processo.

Outro aspecto que destacamos, presente no discurso dos professores-formadores, diz respeito ao conhecimento e domínio da língua-alvo. De maneiras diferentes, há formulações que expressam preocupação com esse aspecto. Vejamos os excertos 15, 16 e 17 a seguir:

Excerto 15 P2: eu vejo assim que é muito difícil... uhn... pensar na/nos nossos alunos como um profissional completo porque... éh... ((suspirou)) a gente trabalha com diversos níveis de alunos e diversos focos de interesse... né então tem muito aluno que vem fazer língua inglesa... mas não quer fazer língua inglesa... na verdade... só queria língua portuguesa... então esse aluno... às vezes... te jura de pé junto que não vai fazer/que não vai fazer não... que não vai dar aula de língua inglesa e no final ele acaba dando aula de língua inglesa... e aí... a gente tem uma relação extremamente complexa... né... porque a gente tem uma sala completamente heterogênea... com alunos que têm um bom conhecimento... depois alunos que têm conhecimento mediano e aqueles alunos que não têm absolutamente nenhum conhecimento... não é?... e aí eles sempre falam que tem que nivelar por/por baixo... e essa relação do nivelamento por baixo acaba meio que desestimulando tanto aqueles alunos meio... de... nível médio... como de nível um pouquinho mais/mais avançado... né? ... então nesse sentido... o professor meio que se sente de mãos atadas... né dentro desse processo todo...

$\mathrm{Na}$ enunciação acima, a questão da dupla habilitação (português/inglês) é trazida. Notamos que ela parece funcionar como subterfúgio para "justificar" o baixo desempenho na língua-alvo. No dizer dos alunos (vozes resgatadas na cadeia discursiva), não há necessidade de "dominar" a língua inglesa, pois essa não será a área escolhida para ensinar. No entanto, de acordo com a formulação de P2, isso acaba funcionando como uma desculpa para justificar o nível precário da língua inglesa e que no futuro, certamente esses mesmos alunos irão eventualmente também ensinar inglês, "na hora da dificuldade". Com a enunciação acima, depreendemos um efeito de desconforto frente à diversidade (de interesses, níveis, concepções), gerando um conflito no professor-formador ("o professor meio que se sente de mãos atadas"). O efeito de indeterminação veiculado pelo pronome "eles” sugere, sobretudo,

105 Conceito elaborado por Jacques Lacan, que, segundo Žižek (1988/1991, p. 198), refere-se a "um ato essencialmente contingente pelo qual o campo ideológico-simbólico determina retroativamente suas 'razões"”. 
que há uma interferência externa (institucional, mercadológica etc.), ou até mesmo do alunado, que demanda uma atitude pactuária ("eles sempre falam que tem que nivelar por baixo"). Ou seja, a formação está pautada no conhecimento mínimo, busca-se assegurar um saber basilar no qual estará contida a grande maioria dos alunos. $\mathrm{O}$ pacto que se estabelece, nessa instância, visa, portanto escamotear as diferenças, deixando os alunos que têm "bom conhecimento" de inglês à deriva, ou, conforme apontado no excerto 13, a formação está "por conta" do próprio aluno.

Antes de analisarmos a enunciação contida no excerto 16, consideramos importante caracterizar, brevemente, seu enunciador, para melhor compreensão da instância pactuária que vamos sugerir. P9, que exercera a diretoria e a coordenação pedagógica em uma escola da rede oficial de ensino, à época da entrevista, além de atuar no curso de licenciatura como professor-formador, tinha responsabilidade pela orientação e acompanhamento do estágio supervisionado na Instituição 1. Passemos, então, ao excerto:

Excerto 16 P9: [...] inglês é uma coisa assim que me incomoda... o aluno... ele não sabe inglês... poucos sabem... e não têm interesse em saber de fato inglês... tem muito aluno preocupado só com o diploma... que diz assim... "eu vou trabalhar só com português mesmo... com inglês não..." aí eu falo... "mas tu é habilitado em inglês... então você tem que querer saber... conhecer... de realmente dominar... afinal de contas... você tem uma certificação que na prática não serve para nada..." "ah professora se eu for dar aula de inglês aí eu vou para um cursinho... eu vou me aperfeiçoar... mas se eu for para o estado... dependendo de onde for... qualquer coisa que eu for fazer serve" $[\ldots]$ o inglês é uma língua que foi a vida inteira mal trabalhada [...] eles vêm com essa reclamação principalmente das escolas estaduais... onde o professor da língua inglesa... ele não domina nada... não passa nada [...] tudo gera mais descrédito ainda na língua inglesa... a prática dos professores de inglês no estado... na prefeitura... é bem ruim... os professores desconhecem... é só exercício sem nenhuma conversação... sem nenhuma experiência... sem nenhum laboratório... e aqui acaba que eles são resistentes... vêm trazendo isso... que vem da vida estudantil deles... desde sempre... e aqui na faculdade repetem o modelo...

O incômodo com o fato de os alunos expressarem pouco interesse em aprender a língua inglesa também aparece na enunciação acima. A partir das formulações trazidas, vê-se que o interesse dos alunos está voltado apenas para a certificação, constatação que o professor-formador parece tentar combater. Conforme apontamos no excerto 15, a questão da habilitação dupla acaba funcionando aqui também (excerto 16), como uma "desculpa" para justificar o "baixo desempenho" na língua-alvo. Dessa forma, temos representações acerca do ensino da língua inglesa, nas escolas estaduais, e do seu professor, construídas durante o 
período do estágio supervisionado e, notadamente, durante a "vida estudantil" dos alunos, que parecem sedimentadas: a) só se aprende inglês em escolas de idiomas, b) o professor de inglês da escola estadual não "domina” a língua e não consegue ensiná-la.

Partindo da materialidade lingüística, notemos como tal efeito é provocado pelos sintagmas: "vida inteira", "vida estudantil" e "desde sempre" inseridos em formulações narrativizadas: "foi a vida inteira mal trabalhada", "vem da vida estudantil deles... desde sempre". Há também um efeito de totalização no enunciado "tudo gera mais descrédito ainda na língua inglesa", rendendo ao discurso uma noção de impossibilidade. Cria-se, assim, uma barreira, aparentemente, intransponível, cujas bases estão fortemente enraizadas. Diante do discurso da impossibilidade, parece-nos plausível interrogar sobre os objetivos do ensino de língua inglesa nas escolas estaduais. O enunciado "o inglês é uma língua que foi a vida inteira mal trabalhada" nos permite um modo de entrada nesse universo do impossível, pois cabe ponderar sobre a maneira de tornar o inglês "bem trabalhado". A despeito das interferências do professor-formador para tentar agir sobre as representações trazidas pelos alunos, notemos o efeito de resignação provocado com o segmento abaixo:

Excerto 17 P9: [...] eu vejo muito professor de inglês na rede... eles falam isso... o professor está sempre insatisfeito... está sempre reclamando... inglês não vale nada... inglês não reprova $[. .$.$] eu acho que é uma coisa que vem... culturalmente... a$ vida inteira... inglês sempre foi para poucos né [...] dentro das salas de inglês... ainda tenho::: visto muito resistência... "olha inglês não é uma coisa que funcione na grade no estado..." e não funciona mesmo né ((exclamou))... porque na nossa grade estadual ele não reprova... só é uma matéria que se somando a mais três aí faz um pacto... mas ela por si não tem interferência nenhuma... então essa desvalorização já vem do sistema... e que a gente vai... perpetuando... até porque eu acho que é um instrumento de::: de domínio mesmo... quem tem o inglês? é para poucos... interessa ao governo que poucos dominem o inglês... porque quanto mais dominar... quanto mais conhecimento... é uma pessoa difícil de lidar [...] é isso que eu tento discutir com eles e desvelar com eles... a favor de quem e contra quem está esse ensino de inglês? quem ganha e quem perde com isso? mas ainda há::: muita resistência... isso me incomoda demais...

Deparamo-nos, novamente, com materializações lingüísticas sugerindo a impossibilidade de transformação, por estarem atreladas ao "sistema". Notemos como esse efeito é produzido pela reiteração dos advérbios "sempre", "nada" ("inglês não vale nada") e "culturalmente". Ademais, as nominalizações em "desvalorização" e "resistência", além da locução verbal "vai perpetuando", sugerem a permanência da impossibilidade. Para Cardoso (1999/2003, p. 82), as nominalizações se apresentam no discurso "como uma forma de 
introduzir uma 'verdade' já posta, um dado 'inquestionável'”. De fato, podemos observar como tal mecanismo enunciativo rende ao fragmento discursivo apresentado um efeito de verdade absoluta. Notamos na cadeia discursiva uma tentativa redentora no sentido de levar os alunos à reflexão sobre a importância da língua inglesa, no entanto, há um efeito de compreensão por parte do professor-formador. Vemos, desse modo, posturas que se conflitam, que, da nossa visão, são reflexos de um contexto cujos paradigmas educacionais estão em transformação. No discurso, há o esboço de um professor-formador "imaginário", que busca encorajar, incentivar os alunos para a educação. Entretanto, tal atitude se mostra diluída, enfraquecida, ao deparar-se com uma situação "real” escolar. Esse efeito é provocado pela inclusão de um "enunciador-universal"106, no ato da enunciação: "olha inglês não é uma coisa que funcione na grade no estado..." Diante desse quadro, o professor-formador parece estar aprisionado, de modo inescapável (“e não funciona mesmo”). Em face de tal indefiniç̧ão e indeterminação (de papéis, objetivos, concepções), há no enunciado acima um efeito de resignação frente a uma estrutura macro (Estado, Governo, cultura, sistema) que perpetua, constrói representações com as quais, aparentemente, não há possibilidade de enfrentamento. É por isso que depreendemos aqui a constituição de um pacto, em uma instância transcendente, exógena, na qual os sujeitos (professor-formador e alunos) são mantidos no status quo de modo imponderável. Acrescentamos, ainda, outros dizeres dos alunos, trazidos por P9, sobre a tentativa de intervenção durante o estágio (observação de aulas), no sentido de sugerir ou propor alguma atividade para o professor responsável pela aula observada durante o estágio. No entanto, conforme $\mathrm{P} 9$, o que os alunos ouvem dos professores da rede pública é o seguinte: "você chega cheio de idéias daqui a pouco você está que nem a gente..." Ou seja, parece existir também, por parte dos alunos, a mesma atitude redentora, mas que se desvanece diante do discurso da impossibilidade.

\subsection{A linearização de procedimentos e deveres}

Nesta seção, trazemos excertos que abordam atividades de natureza didática e pedagógica realizadas pelos professores-formadores. Por meio de uma categoria de análise que nomeamos "linearização", entendemos que há um processo narrativo-descritivo de ações realizadas por esses sujeitos que sugere uma dependência seqüencial de procedimentos, os

\footnotetext{
${ }^{106}$ Retomando contribuição de Guimarães (2005), o "enunciador-universal” designa uma perspectiva enunciativa que se apresenta acima da história, é "o lugar do qual se diz sobre o mundo" (p. 26). O autor esclarece, como exemplo, que esse é o lugar, entre outros, do discurso científico.
} 
quais produzem efeitos na concepção de formação de professores. A fim de mostrarmos como vemos essa dependência de fazeres, passemos aos excertos:

Excerto 18 P1: [...] formar professores é um acidente... um acidente de percurso... vai ou uma::: uma::: decorrência... mas na verdade, meu intuito é sempre formar::: éh... ((suspirou)) pessoas críticas... críticas no sentido mesmo da... da não aceitação das imposições... das ideologias... né do que o professor diz [...] a primeira coisa é desmistificar o objeto não é... o objeto com que eu trabalho vem sempre cercado de muita de muita mistificação... tanto positiva quanto negativa... mais negativa do que positiva... ahn... a principal coisa que eu faço éh... justamente desmistificar né... a imagem desse objeto em todos os sentidos... quer dizer.... éh éh e aí é claro que sobra farpas para todos os meus colegas professores... ou seja no fundo eu vou dizer... "olha o grande culpado das mistificações são justamente os professores"... eles mistificam muito né... tanto para o bem quanto para o mal [...] se a intenção for... né ser mais do que meros professores... professores no sentido... vai rasteiro do termo que se usa né... professor de... nível médio... todo mundo pode ser professor de nível médio... mas acho que a gente não pode querer ficar só no nível médio... acho que a gente tem que querer mais...

A primeira formulação que nos chama a atenção trata da visão que esse sujeito tem de si: não se vê como formador de professor. Para esse sujeito, então, a formação de professores é algo que ocorrerá em momento ulterior como uma "decorrência" ou ainda um "acidente de percurso". A seqüência estabelecida, desse modo, passa a ser, em primeiro lugar, a formação de um indivíduo crítico que, para esse sujeito, significa alguém que saiba contestar "com razão", para depois se pensar em formação de professores. Sua justificativa está pautada no fato de que "ser mero professor" já é uma condição dada. Esse postulado não deixa espaço para se refletir sobre a formação, pois o status de professor está posto independentemente de qualquer esforço. Essa visão adulterada sobre o curso de formação causa um efeito de depreciação da profissão docente. No entanto, vemos que fatalmente funciona também de maneira ardilosa para incluir esse sujeito na "armadilha" que tenta revelar. Especifiquemos: os "professores" são apresentados como "culpados" por mistificações, contudo, no conjunto das formulações, esse sujeito também mistifica a questão da formação de professores, pois não há espaço para ela se, primeiramente, os alunos não se tornarem "críticos". Ou seja, emerge do discurso uma noção de formação (postergada) como meta decorrente de uma preparação crítica. Desse modo, no discurso, a formação de professores parece dissociada de tal visão crítica, como se ela não pudesse ocorrer junto com a "preparação crítica".

Examinemos outro modo de estabelecer dependência de procedimentos com relação à formação de professores: 
Excerto 19 P2: [...] eu sinto que tem uma deficiência muito grande... ah... por parte dos alunos $[\ldots]$ a gente trabalha assim com praticamente... vários níveis né... [...] 0 aluno que chega... e não tem nada e vai correr atrás e vai sair sem conseguir falar... ou ter estrutura de quase nada... a gente trabalha com um tipo de aluno que... vem e sabe muito mas também não vai estar interessado em... estar dividindo esse conhecimento com os outros alunos e a gente trabalha com o tipo de aluno meio que mediano que "ah o que vier ta bom e o que não vier também ta:.: ta bom..." então eu vejo essa problemática por parte dos alunos... na minha parte [...] eu sinto assim que... que falta mais oportunidade pra (ir) fazer... algum outro curso... palestra de:.: ... (vamos dizer assim) de atividades relacionadas com as dinâmicas né... eu sinto um pouco dessa/dessa deficiência [...] então eu sinto assim que existe uma passividade muito grande né por parte dos alunos... não éh... e quando não existe essa passividade quando a gente tenta fazer alguma outra coisa... ahn... existe assim um/um pouco da falta de/de interesse...

Nesse segmento (excerto 19), observamos que a formação de professores parece estar comprometida, em virtude, primeiramente, da falta de preparo dos alunos (proficiência na língua-alvo) - aspecto já detectado na seção anterior, bem como em relação ao próprio preparo do professor-formador. Esse sujeito esboça um perfil marcado por uma falta (de algum curso, palestra, dinâmicas), fazendo com que a formação dos alunos se inscreva de maneira condicionante. Temos, desse modo, um tipo de relação estabelecida, de forma temporária, na qual, por um lado, a "diferença de níveis" dos alunos se torna empecilho para a formação, e, de outro lado, a "falta" detectada pelo professor-formador também se constitui em fator, aparentemente, impeditivo para se trabalhar com a questão da formação de professores, nesse contexto. Essa dependência volta a emergir do discurso, quando a questão das atividades docentes é mencionada. Vejamos a seqüência a seguir:

Excerto 20 P2: [...] basicamente tento dar aulas práticas... mas... não ta muito possível ultimamente... eu diria... porque você só tem um/um tempo limitado de cinqüenta minutos $[\ldots .$.$] mesmo apresentando o aspecto prático da questão... a$ gente percebe que não tem muito espaço pra discutir as possibilidades... né... a bem da verdade... eu gostaria de dar muito mais coisas práticas ou... ou cursos né que pudessem ser voltados a::: a esse lado da praticidade... que eu quero dizer... a possibilidade de::: chamar alguém da área mesmo pra situar alguns tópicos... que eu acho que seria assim... interessante... né... mas... mesmo dentro desse questionamento prático... às vezes a gente percebe que os alunos... às vezes... não estão interessados nesse questionamento prático ou nessa produção de material prático... porque... muitas vezes... ele se... né se sente... não atraído pela questão mesmo da língua inglesa... né então... acho que existe uma deficiência... né nesse aspecto... por/pela questão do envolvimento do aluno... e uma deficiência minha mesmo... por parte do professor... por/pela questão mesmo de... talvez não conseguir fazer algum aspecto mais de reciclagem... de trazer outras pessoas pra virem participar::: desse processo de discussão da questão prática né e.:.: ... então acho que/que... é meio pobre... né infelizmente... 
Nesse outro momento da enunciação, o sujeito volta a formular sua necessidade de procurar algo externo para complementar suas aulas, tornando-as mais "práticas". Como esse elemento outro não é trazido, cujas causas podem estar relacionadas a questões institucionais, burocráticas, administrativas ou pessoais, a "praticidade” esperada não é obtida, pois ela está condicionada a esse fator externo (um outro professor, curso, reciclagem). Somando-se a esse aspecto, há também a limitação do tempo (já apontada na seção anterior) e a atitude "desinteressada" dos alunos com relação ao "questionamento prático". Com isso, esses aspectos passam a figurar como "impeditivos" da formação, ou seja, para pensar em formação de professores, nesse contexto analisado, é preciso seguir uma seqüência, na qual teremos: a) alunos interessados e proficientes na língua-alvo; b) tempo disponível; c) preparo do professor-formador.

Sobre o interesse dos alunos, evocamos aqui a maneira como Popkewitz (1998, p. 50) encara essa questão: the 'lack' of capabilities noted as students 'not motivated', 'not prepared', and 'not present in the classroom' is the struggle for the soul. The moral responsibility of the teacher is to re-vision the inner beliefs and feelings of the child. Observamos que, no excerto 20 , bem como em outros momentos analisados, o despertar do interesse, a tentativa de (re)direcionar perspectivas descrevem momentos nos quais o professor-formador busca um "resgate da alma"107 do aluno, uma essência perdida. No entanto, o resgate de tal essência torna-se desvanecido, pois há ainda outras questões a serem resgatadas: tempo escasso, inclusão de auxílio externo ("alguém da área") para discutir "praticidade". Além disso, nota-se que deve haver um movimento de "resgate da alma" do próprio professor-formador, uma vez que sua "falta" parece desvinculá-lo da atividade de formação. Ou seja, tem-se a impressão de que o modo de dizer torna P2 excluído da "área de formação". A questão da "prática" torna-se mitificada ao ser transportada para um momento “outro" longínquo. Há um efeito de desvanecimento no conjunto das formulações do excerto 20, encimado pelo dizer "é meio pobre". Com isso, concluímos que a questão do "resgate da alma" opera nos níveis docente e discente. Reiterando aspectos já apontados, vemos, nos excertos 19 e 20, o recorte de uma situação na qual há convergências de paradigmas. Por um lado, há uma visão educacional da modernidade, pautada na "completa" preparação docente, no controle sobre fazeres e saberes. No entanto, dada sua impossibilidade, o sujeito parece apartar-se ou posicionar-se de modo expectante em relação à formação, não se vendo

\footnotetext{
${ }^{107}$ Estamos emprestando a expressão no sentido em que ela é usada, criticamente, por Popkewitz (1998) para se
} referir à "responsabilidade moral" do professor de rever crenças e sentimentos dos seus alunos. 
suficientemente preparado para discutir a questão da "prática". Por outro lado, a tentativa de uma construção de conhecimento conjunto, concepção que a pós-modernidade ajuda a formular, também parece estar obstada pela "falta de interesse" por parte dos alunos.

Passemos para outro excerto, no qual observamos essa dependência de fazeres ocorrer também em um "nível emocional":

Excerto 21 P4: [...] uma coisa assim que eu procuro... que eu me vejo éh... acima de qualquer conteúdo... é transmitir para o aluno o gosto pela língua portuguesa... então eu me vejo assim ah... tentando desmistificar toda essa coisa que "a língua portuguesa é difícil... que não sei quê não sei quê" [...] eu tenho muito... muita paixão pela língua... procuro... não é que eu procuro... eu me vejo relacionando... me relacionando com eles éh... num nível bastante emocional... pra que eles percebam né essa coisa bonita da língua portuguesa... mas eu privilegio conteúdo... né... e::: procuro ah... eu procuro fazer com que eles reflitam qual é a aplicabilidade desse conteúdo fora de... fora da questão mais formal $[. .$.$] eu acredito que eles... na hora que eles articularem essas$ coisas é que aí eles vão ter paixão pela língua...

Embora o trecho acima selecionado não envolva aspecto mais direcionado à língua inglesa, nosso interesse é mostrar como vemos esse processo de linearização ocorrer em diversos níveis, formas e por diferentes sujeitos. De maneira análoga à formulação apresentada no excerto 18, aqui, notamos que, primeiramente, é preciso desmistificar o objeto de estudo por meio de um despertar da "paixão pela língua". Cria-se, com isso, uma sucessão de condutas ou procedimentos que culmina com a questão do conteúdo. Notamos que não há menção sobre a formação de professores em si, dando a impressão que ela é desconectada desse processo ou que, ainda, ocorrerá de modo aleatório. A formulação final aponta para uma noção de contingência: "na hora que eles articularem essas coisas é que aí eles vão ter paixão pela língua". Depreende-se que somente após os alunos terem percebido a maneira como a língua é usada, eles serão capazes de desenvolver essa "paixão pela língua". Assim, considerando a dependência de fatores exposta (gostar, desmistificar, privilegiar conteúdo e articular), supomos que a questão da formação está situada em momento posterior a essa articulação mencionada, ou seja, poderá ocorrer de maneira contingente e extemporânea.

Encontramos outra questão sobre o perfil do professor universitário de inglês que julgamos importante no excerto 22. Destaca-se um fator que parece constituir-se em "empecilho" para a formação de professores de inglês. Vejamos o excerto: 
Excerto 22 P7: [...] eles [alunos] esperam éh... uma aula de inglês naqueles moldes de escola de língua cheia de games e não é um ambiente pra isso né [...] coisas que são acadêmicas... discutidas na área de português... são bem menos discutidas em inglês... porque tem a formação lingüística que acompanha e limita e infantiliza o curso [...] o professor de inglês tem que ser mais dinâmico de todos da faculdade... quer dizer eles não pedem dinamismo pra a aula de literatura portuguesa né... eles dão aquelas aulas em que o professor fica sentado atrás da mesa com o livro aberto explicando... eu tenho que ficar em pé... a aula inteira... dando aula em pé... girando... fazendo pair-work... micagens e trazendo papel cortado... ((risos)) na cartolina... então eu éh... eu acho... nas faculdades particulares em que os alunos começam a aprender inglês na faculdade é muito difícil a formação de professor né...

A queixa apresentada na enunciação (excerto 22) revela a existência de um paradigma, com o qual o professor universitário de inglês se depara e busca romper, que é a noção de ensino de inglês nos moldes de uma escola de idiomas ou como um revival, um pouco mais avançado, do Ensino Médio. ${ }^{108}$ Isso, na nossa visão, ajuda a estabelecer o que temos chamado de processo de linearização na formação de professores de inglês. Temos um painel, no qual, no primeiro momento, é preciso romper com a expectativa dos alunos com relação ao professor universitário de inglês para, em seguida, formar um falante da língua. Novamente, vemos que não sobra espaço para se discutir a formação de professores. A formulação trazida no excerto 22 sobre "coisas mais acadêmicas", que parecem envolver aspectos não conteudísticos, tais como: aquisição e aprendizagem de línguas ou mesmo sobre formação de professores, ficam circunscritos à habilitação da língua materna. Ou seja, nessa ótica, o professor universitário de inglês, no universo da instituição privada, precisa, primeiramente, romper com a barreira da proficiência lingüística e com a visão distorcida sobre o ensino de inglês no Terceiro Grau, para, enfim, começar a pensar em formação de professores.

Desse modo, acreditamos encontrar, no excerto 22, a captura de um conflito vivido pelo professor-formador com relação ao rompimento do paradigma acima descrito. De forma simultânea, ele descreve a expectativa do aluno com relação à disciplina língua inglesa na universidade (com a qual tenta romper), mas sugere que acaba assumindo papel mais "dinâmico" para atender a essa expectativa. Nesse nível que acabamos de expor, então, o "resgate da alma" busca, primeiramente, um amadurecimento do aluno, pois seu comportamento é descrito como infantil, distorcido e imaturo, conforme vimos no excerto 4.

\footnotetext{
${ }^{108}$ Remetemos o leitor ao trabalho de Platero (2000), citado no capítulo Formação de professores, no qual a pesquisadora aponta essa questão do ensino de inglês visto como "revisão" do nível anterior (Ensino Médio em relação ao Fundamental) ou como "preparatório" para o nível seguinte (Ensino Médio para Terceiro Grau).
} 
Em seguida, deve-se transformar a visão trazida pelos alunos sobre o ensino de língua inglesa na universidade. Somente após ocupar-se com tais procedimentos, o professor-formador poderá voltar-se para a questão da formação. Em outras palavras, ela poderá se concretizar em um futuro contingente.

Cinco professores-formadores, entre nove entrevistados, apresentam a docência como ato de muita responsabilidade, pois sabem que os alunos buscam modelos e que eles são modelos para esses alunos. Detenhamo-nos em uma observação de Popkewitz sobre essa questão:

The notion of role model itself establishes an imaginary "nature" in which certain norms are inscribed about what children should have but lack. These norms are to rescue the child so that its "soul" has "morality", "fairness", "kindness", and "tolerance". [...] The idea of role model embodies a moral responsibility to rescue the child. The teacher as role model assumed a particular outlook about certain universal values about childhood that would morally uplift students by regulating behavior and manners. By having children model teachers' actions and behaviors, a redemptive quality can be instituted in the child. (1998, p. 51-52)

Com efeito, notamos que essa atitude redentora, de que nos fala esse teórico, está expressa em alguns enunciados. Vejamos como o excerto abaixo ilustra tal questão:

Excerto 23 P5: [...] procuro colocar sempre pra eles a questão da... da... não só... ( ) fundamental/do conhecimento técnico mesmo da coisa... da... da... língua inglesa... mas também da responsabilidade que eles têm na formação desses alunos com os quais eles vão trabalhar... quer dizer... formar alunos críticos... alunos pensantes... éh... sabe... éticos... assim no comportamento como profissionais como pessoas e lembrando que eles vão ser modelos [...] eu sempre lembro isso pra eles que como professores... futuros professores... eles têm obrigação MORAL de formar pessoas críticas [...] eu faço primeiro toda uma introdução daquilo que eu vou trabalhar e depois eu boto eles pra trabalhar também... eu acho que só assim quando eles saírem daqui eles vão... éh... vão... ser capazes de... de... pesquisar... de ir atrás... acho que a gente tem que lançar essa... essa semente da pesquisa...

Na visão desse professor-formador, a docência requer muita responsabilidade, pois formar alguém crítico é formar alguém "pensante e ético". Ou seja, essa questão ética tem um efeito que se aproxima do "resgate da alma", mencionado por Popkewitz (1998), despertando no aluno valores que poderíamos entender como generosidade, integridade, moralidade etc. Desse modo, considerando sua visão sobre a questão dos modelos, entendemos que esse resgate ou despertar de valores que os professores-formadores possam supor que os alunos 
não têm, na trilha que temos seguido, nesta seção, pode constituir-se em um embate tardio que poderá fazer com que questões relativas à formação de professores não encontrem terreno para discussões, ou possam se tornar obscurecidas. De modo semelhante, as formulações sobre a postura esperada para um aluno universitário (excerto 3) e sobre o comportamento “desrespeitoso e infantil" desse mesmo aluno (excerto 4) refletem também essa questão do embate inicial no curso de formação de professores.

Vejamos, também, como a formulação que detalha procedimentos didáticopedagógicos parece distanciar a discussão sobre aspectos formativos ao sugerir uma seqüência linear: "eu faço primeiro toda uma introdução daquilo que eu vou trabalhar" (primeiro procedimento); "depois eu boto eles pra trabalhar também" (segundo procedimento). A partir dos marcadores seqüenciais "primeiro" e "depois", obtém-se um efeito de que a "formação" está restrita a um procedimento preparatório apenas. $\mathrm{O}$ fio narrativo parece, a partir dessa fase preliminar, projetar-se para um momento futuro: "só assim quando eles saírem daqui eles vão... ser capazes de pesquisar... de ir atrás... acho que a gente tem que lançar essa semente da pesquisa". Ou seja, cria-se, no discurso, um intervalo que permanece silenciado, tornando o procedimento pedagógico descrito aparentemente desconectado da formação, considerando que, nesse momento da enunciação, o foco estava voltado para atividades formativas ${ }^{109}$. Destaca-se aí o sintagma "lançar semente da pesquisa", que sugere uma aleatoriedade a respeito da noção de formação.

Olhemos para outras formulações que sugerem essa questão do "resgate da alma", observando o trecho que se segue:

Excerto 24 P8: [...] sempre que eu dou qualquer curso ou qualquer aula... eu procuro formar... e não informar né... então eu acho muito mais importante... sempre a minha orientação é essa... eu acho muito mais importante você mostrar os instrumentos de pesquisa... os instrumentos de éh... busca pra eles do que simplesmente você fazer uma passagem de informações... então em todos os cursos seja língua literatura o que for... eu procuro formar uma consciência crítica [...] a partir da literatura que eles possam refletir... e sempre fornecendo... material de pesquisa... nunca trazendo nada completo... porque eu valorizo muito mais esse papel formativo [...] o objetivo de você formar um professor é fazer ESSE professor refletir [...] procurar dar para o aluno um senso crítico... e além do senso crítico um instrumental de busca para que futuramente se ele quiser... éh... procurar alguma... alguma coisa né ele

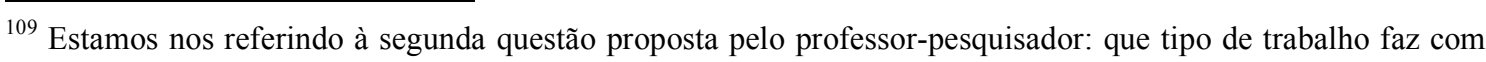
seus alunos que julga importante para sua formação? 
sabe por onde fazer essa pesquisa [...] nós conseguimos despertar um interesse deles para algumas coisas e acho que isso éh... fantástico [...] acho que essa consciência de que "olha a gente fez uma base mas tem muita coisa pra ver ainda e agora... você tem um longo caminho pela frente né... então vai atrás..." e eles saem com essa consciência de que eles precisam de mais... né... e que eles... vão atrás...

As formulações acima (excerto 24) nos remetem à análise das Diretrizes Curriculares que expusemos, no Capítulo 4 da Parte II, sobre as noções de "consciência" e "capacidade de reflexão crítica”. Sintetizando brevemente nossa exposição anterior, postulamos que a palavra "consciência", usada em diversos momentos das Diretrizes, no discurso, provoca um efeito de busca de uma completude, que, juntamente com a ênfase na "reflexão crítica", evoca a construção do perfil de um lifelong learner. No excerto 24, por meio de uma memória de dizeres que constitui o interdiscurso, vemos que tais conceitos despontam. Entretanto, conforme já apontamos, eles deslizam para outras esferas de sentido. Na cadeia discursiva, o termo "formar" parece significar "mostrar instrumentos de pesquisa" e os sintagmas "consciência crítica" ou "senso crítico" estão vinculados à reflexão. Ao observarmos mais duas formulações expressas na enunciação, inferimos que o "despertar do interesse" e a "consciência de que eles [alunos] precisam de mais" encontram proximidade com a noção de "formar uma consciência crítica". Cabe notar que, por meio da polifonia enunciativa, resgatase um dito ("olha a gente fez uma base mas tem muita coisa pra ver ainda e agora... você tem um longo caminho pela frente né... então vai atrás") que produz um efeito redentor, se tomarmos as condições de produção do discurso. Tratava-se do final do ano letivo, momento no qual os professores-formadores refletiam sobre os avanços ocorridos ao longo do período. Ou seja, a base foi instaurada e a responsabilidade pela formação foi dividida com o aluno concluinte ou transferida para ele. Note-se o efeito de autoridade impresso por meio do substantivo pronominalizado "a gente", que podemos entender como sendo uma voz institucional (da universidade), coletiva (dos professores-formadores) ou ainda secional (professores-formadores da área de inglês, implicando o próprio professor-pesquisador).

A análise do excerto 24 soma-se aos anteriores, desta seção, nos quais vimos apontando efeitos produzidos no discurso que entendemos como uma linearização de etapas ou procedimentos. Depreendemos que o primeiro momento envolve a noção desse "resgate da alma", que vimos como o despertar, a compreensão, por parte do aluno, de que, naquele contexto educacional, serão mostrados alguns caminhos e que, portanto, a formação profissional, poderá ocorrer após esse momento ("futuramente se ele quiser... éh... procurar 
alguma... alguma coisa né ele sabe por onde fazer essa pesquisa"). Essa imagem da formação converge para aquela que foi apresentada no excerto 23. Enfim, dentro desse painel preparatório ou procedimental: "formar base", "despertar interesse" (excerto 24) e "lançar semente" (excerto 23), considerando a ausência de formulações referentes à formação de professores, concluímos que não há espaço ou tempo para discutir essas questões, ou tem-se o efeito de que elas parecem ser desconectadas dessa "situação de formação".

Iniciamos análise do excerto 23 , levantando a questão do papel do professor como modelo, citado por alguns professores-formadores. Nesse contexto da Instituição 1, apenas um professor-formador, entre nove entrevistados, mencionou que não se pode falar em modelos, mas sim em estilos de professor. Vejamos mais alguns momentos antes de prosseguirmos com nossa análise:

Excerto 25 P6: [...] eu tento... no meu trabalho... estar procurando esse mergulho que eles façam dentro deles para que eles possam estar enfrentando as/os desafios que eles têm cotidianamente na sua disciplina... (ou) na sua escola... etc... então o meu trabalho é por aí... então... eu trabalho muito a questão... valorizando a experiência né que eles têm... habituar a pegar a experiência... o lado éh... positivo da experiência deles... que eles escapem de todas aquelas... éh... experiências negativas... que elas sirvam de/só de incentivo pra você estar revendo avaliando e ir para frente... trabalho com eles... valorizando em termos do conhecimento né como passar da informação para o conhecimento... que eu acho que é importante esse processo... que eles tenham essa visão e... (e eles tendo) também o domínio do conteúdo... porque sem esse domínio do conteúdo eles não... também não há um... desenvolvimento do trabalho...

Vimos apontando, nos excertos anteriores desta seção, um processo de linearização de atividades e procedimentos que se relacionam de maneira dependente. Observamos que, também no excerto 25 , há uma descrição de procedimentos semelhantes, contudo, vemos uma sinalização de questões que tocam a formação de professores mais especificamente. $\mathrm{Na}$ mesma direção que apontávamos acerca do conceito de "resgate da alma", compreendemos que, no excerto 25 , o primeiro procedimento realizado abrange exatamente tal questão. $\mathrm{Ou}$ seja, o sujeito propõe, inicialmente, aos alunos uma retomada da vida escolar e um resgate das "experiências positivas" e a transformação das "negativas" em incentivo, para, a partir delas, iniciar o trabalho de formação profissional. Cremos que cabe questionar aqui a visão educacional que o resgate proposto suscita. Entendemos que tal atividade pode abranger um universo vasto, incerto e complexo para ambos, alunos e professores-formadores. Caberia interrogar como essas "experiências negativas" durante a vida escolar foram registradas (se 
foram) pelos alunos e como a ressignificação (transformá-las em incentivo) poderá ocorrer. O resgate, na forma como é apresentado, parece ter um efeito de procedimento terapêutico, que supomos demandar tempo. Após a fase de ressignificação ("ir para frente"), então, aparece a passagem da informação para o conhecimento (que entendemos aproximar-se da questão da formação de professores) e o domínio do conteúdo ${ }^{110}$ como etapas para o desenvolvimento do trabalho.

Nos excertos 26 e 27 a seguir, trazemos outras formulações acerca das atividades realizadas pelos professores-formadores com o intuito de ajudar na formação dos alunos. ${ }^{111}$ Um aspecto bastante recorrente nas entrevistas é a preocupação ou a afirmação de que há uma busca para que as aulas sejam efetivamente "práticas". Vejamos como isso ocorre:

Excerto 26 P3: [...] eu procuro enfatizar bastante a questão prática... embora eu não dispense a teoria... então eu trabalho com textos teóricos que falam sobre o professor... a relação com o aluno... as teorias... principalmente... as mais recentes da pedagogia... [...] então eu trabalho um pouco com a teoria pra mostrar para os alunos que... é possível sair daquele esquema tradicional... e que a relação professor-aluno é uma relação de:.: de mão única... não é?... em que o professor é detentor do conteúdo e passa isso para o aluno... então... as teorias mais recentes... com as quais eu tenho trabalhado em sala de aula elas demonstram que não é esse o melhor caminho... é preciso abrir... é preciso expandir... é preciso se aproximar do aluno... e incorporar a experiência dele também na prática docente... agora isso é só teoria o que eu procuro fazer mesmo... é em sala de aula... é exercitar a:.: ... fazer com que o aluno exercite a docência... fazer com que cada aluno se responsabilize por um tema... com que o aluno apresente esse tema para os colegas... fazer com que o aluno prepare as suas aulas e depois éh... exponha isso pra sala ou por meio de seminários ou por meio de aula mesmo que o aluno ficou responsável... então eu procuro enfatizar bastante essa prática...

No recorte apresentado, o discurso se configura de modo a motivar um aspecto que já vimos discutindo: a dicotomização entre teoria e prática. Relembramos que, para Popkewitz (1998), essa é uma questão constitutiva na formação do professor. De fato, podemos observar, no dizer acima, o modo como ela é colocada de forma a fazer germinar essa divisão durante o processo de formação. Vemos, igualmente, a sugestão de atividades que apontam para a linearização. Inicialmente, há um efeito de valorização da prática sobre a teoria (“embora eu não dispense a teoria"), ou seja, primeiro procedimento: prática, segundo: teoria. No entanto,

${ }^{110}$ Lembramos que no capítulo que trata das Diretrizes Curriculares, assim como a noção de "consciência", analisamos essa questão do "domínio" sobre conteúdos.

${ }^{111}$ Reiteramos que uma das questões propostas pelo professor-pesquisador foi: que tipo de trabalho faz com seus alunos que julga importante para sua formação? Essa e outras questões foram apresentadas no início do presente capítulo. 
mais adiante, deparamo-nos com ações "teóricas" ("é preciso abrir... é preciso expandir... é preciso se aproximar do aluno... e incorporar a experiência dele"). Observe-se o efeito de diminuição de tais ações com a presença da expressão "agora isso é só teoria”. É com esse movimento contrastivo que entendemos ocorrer a instauração ou a intensificação dessa dicotomia. Contudo, atentemos para o fato de que o dizer desse sujeito mostra que, de certo modo, ele é ludibriado pela separação estabelecida, pois, ao enunciá-la ("agora isso é só teoria"), na verdade, lista procedimentos "práticos". Ou seja, emprega noções práticas para fazer referência à teoria que é apresentada como "esquema tradicional". Logo mais, volta a utilizar-se de conceitos teóricos (exercitar a docência por meio de aula/seminários) para referir-se a "questões práticas". No nosso entendimento, preparar uma aula envolve um conceito teórico, assim como preparar um seminário. Sendo assim, aplicando considerações de Popkewitz (1998) aos nossos propósitos, não obstante o efeito de separação entre teoria e prática, nas formulações trazidas no excerto 26, podemos observar como ambos os conceitos são e estão associados. Nosso empenho em discutir essa questão ${ }^{112}$ reside no fato de supormos que, apesar da não-intencionalidade, criar, gerar ou intensificar uma separação pode postergar a compreensão sobre a legitimidade de se ter uma atitude comprometida com a formação. A própria questão da divisão (teoria/prática) se constitui em um processo de linearização com o qual o professor-formador parece estar envolvido, tornando a formação docente adiada.

A respeito da tônica da praticidade relacionada às questões das atividades em aula, voltemos nosso olhar, novamente, à formulação trazida no excerto 24 , sobre o qual comentamos a valorização da "consciência crítica" e "reflexão" para, em seguida, compararmos com esta enunciação:

Excerto 27 P8: olha uma coisa que eu sinto falta que eu acho que::: ... eu acho que isso é um pouco da limitação da estrutura universitária em três anos... é um pouco de... de... de poder ver a prática do aluno [...] eu sinto falta de um tempo... pra que eu pudesse... avaliar né... o o/a aula do aluno... desse futuro professor né... como é que esse futuro professor daria aula... né... e aí sobre literatura língua ou qualquer outra coisa né... acho que isso falta... isso eu sinto falta... e isso é uma coisa que eu olho pro programa e não consigo encaixar... né...

Ao examinarmos esse outro momento da enunciação de P8, notamos o efeito dissociativo provocado no discurso com relação à "prática" dos alunos. O sujeito descreve

112 Analisamos recortes semelhantes no capítulo sobre as Diretrizes Curriculares, como também mencionamos que, em algumas pesquisas resenhadas no capítulo Formação de professores, a maneira como essa questão dicotômica é apresentada suscita a instauração ou intensificação de tal divisão. 
uma falta que atribui à questão da duração do curso e também à sua incapacidade de incluir, no programa, momentos de amostragem de uma "prática" futura dos alunos como professores. O efeito de dissociação que sugerimos é obtido por meio da ênfase para a reflexão como ação constitutiva da formação. Todavia, tal reflexão parece não contemplar a questão da "prática" do futuro professor, isto é, na cadeia discursiva, a "prática" não aparece como parte da reflexão. Sendo assim, depreende-se que o espaço que lhe é reservado está ainda por vir. Ou, conforme comentamos no início da seção, tem-se um efeito de que não cabe discutir a formação de professores durante essa etapa de desenvolvimento ou "preparação crítica" do aluno.

Nos excertos apresentados a seguir: 28, 29 e 30, encontramos formulações que sugerem, primeiramente, a necessidade do despertar de um "novo" ponto de vista nos alunos, para, em momento posterior, incluir a formação de professores. Passemos a eles:

Excerto 28 P4: [...] eu acho que se ele [aluno] assume essa postura... "eu sou um profissional... isso daqui é uma ferramenta... não é simplesmente um conteúdo que eu tenho que fazer prova... porque tenho que tirar um diploma" [...] aí eu acredito que a coisa vai florescer mais do que já é...

Nesse excerto, também por meio da polifonia enunciativa, temos a descrição de uma postura "desejável" do aluno. Podemos inferir que, de acordo com a enunciação, o aluno em formação não se vê como profissional, pois a formação está pautada em um procedimento linear de causa e efeito: adquire-se conteúdo, avalia-se o grau de aquisição do conteúdo e, finalmente, atribui-se a certificação. Uma ruptura com essa cadeia implica o desenvolvimento de uma "postura profissional", ou seja, há uma fase preliminar na qual o professor-formador deve, inicialmente, agir, despertando no aluno um desejo de transformação (de concepções e perspectivas). No entanto, a partir da enunciação mostrada no excerto 28 , essa intervenção seminal, supondo que ocorra, surtirá efeitos (irá florescer) de modo casual, incerto, condicionado a circunstâncias diversas.

Continuando nessa linha de raciocínio, tomemos outras formulações que, no nosso entender, reforçam esse caráter condicionante, transitório e duvidoso no que diz respeito à formação do aluno. Tomemos o próximo excerto: $:^{113}$

\footnotetext{
${ }^{113}$ Este trecho foi analisado, parcialmente, em momento anterior. Conforme já orientamos, há excertos que se prestam a diferentes propósitos ao longo da análise, daí a necessidade de retomá-los.
} 
Excerto 29

P7: eu acho que... a característica positiva nem é tão dos alunos é da oportunidade que eles têm de fazerem... de estudar mais né... poder fazer pós eles têm mais ambição de continuar os estudos depois que eles terminam a faculdade [...] parece que eles querem continuar estudando... porque eu acho que/aquela/ou a sensação de não ter aprendido nada é tão grande que parece que sempre tem que buscar mais [...] eu acho que os alunos saem superfrustrados o nível de frustração dos alunos do terceiro ano com a língua inglesa é muito grande... [...] eu penso que eles saem bem frustrados porque eles não têm muita opção de mercado né então a gente tenta... prometer várias coisas que vai ser melhor tentar formar incentivar para uma pós-graduação eu acho que eles saem assim com vontade de estudar a formação deles não é...

No excerto 29, há uma sugestão de que a característica "positiva" dos alunos, na verdade, é mais circunstancial do que pessoal. Considerando as inúmeras possibilidades existentes no sistema educacional que compelem esse aluno a continuar seus estudos, P7 vê como importante a "oportunidade que eles têm de fazerem... de estudar mais né... poder fazer pós eles têm mais ambição de continuar os estudos depois que eles terminam a faculdade". Conforme já mencionamos (excerto 4), a formulação: “eles saem assim com vontade de estudar a formação deles" apresenta certa ambigüidade. Se tomarmos a "formação" como uma relação causal, na qual seu sentido seria a preparação (para uma função ou tarefa), que levaria à efetiva execução (de tal função ou tarefa), como entender o efeito metalingüístico obtido por meio do sintagma verbal "estudar a formação"? A formação não foi suficiente, adequada, proporcional ao que se esperava? A partir de qual parâmetro é possível se afirmar que a formação foi adequada? Somada a essas questões, a tentativa de prometer, incentivar a continuidade dos estudos faz emergir do discurso uma associação que aponta para um tipo de formação postergada, um "sentido" da formação que se obterá alhures, após a conclusão do curso. O mesmo efeito é também obtido no excerto a seguir:

Excerto 30 P8: [...] dentro da medida do possível... o aluno sai com o pensamento um pouco mais crítico do que ele entrou [...] acho que ele aprende a ser crítico ele aprende a buscar algumas coisas... mas eu acho que a FORMAÇÃO dele não é sólida... nesse universo da instituição privada [...] então o aluno que se forma aqui ele... cinqüenta por cento quer ir atrás de alguma outra coisa mais... quer ir atrás para uma pós-graduação acha que tem que continuar o estudo acha que tem que... fazer uma especialização alguma coisa né... e eu acho isso importantíssimo né... [...] eles saem com essa vontade acho que essa é a palavra essa vontade... né de buscar mais coisas [...] então eles vão procurar uma pós... uma especialização alguma coisa... esse incentivo... esse despertar o desejo... né... de conhecer mais... a vontade de conhecer mais... a vontade de levar esse estudo essa reflexão que eu falei essa crítica... pra frente [...] eles entendem que três anos de universidade não é suficiente ((risos)) né... eles entendem assim "ó três anos... não bastou pra mim... né... e.:.: eu não quero só o diploma eu quero... eu quero... me desenvolver..." 
Como já acenamos, vemos, no excerto 30, marcas que indicam uma dubiedade na preparação docente do aluno, que, conforme vimos defendendo, apontam para um adiamento da sua formação. Primeiramente, destacamos a descrição de um processo de aprendizagem marcado pelo desenvolvimento do "senso crítico". Tal criticidade parece ser fruto da vivência universitária, porém, o resultado desse aprendizado surtirá efeito no futuro, momento no qual o aluno irá "buscar mais coisas". Ou seja, tomando as formulações do excerto 30, o despertar da "vontade" de procurar, de "buscar mais coisas" surtirá resultados após a "formação". No discurso, o espaço "durante" parece ser "indizível", silenciado. O desenvolvimento da capacidade crítica se instaura como característica complementar na formação, como um apêndice. Embora tal característica seja considerada produtiva, seus efeitos estão inscritos no terreno do acaso, do futuro, incerto e contingente.

Notamos a consonância das formulações apresentadas nos excertos 29 e 30 por meio dos sintagmas "estudar mais", "fazer pós" (excerto 29) com "buscar algumas/mais coisas" (excerto 30), que se assemelham também quanto ao uso das nominalizações: "especialização", “incentivo", "desejo" (excerto 30) e "ambição" (excerto 29), que, conforme nos diz Cardoso (2003, p. 82), se apresentam “como uma forma de introduzir uma 'verdade' já posta, um dado 'inquestionável"”. Para este trabalho, tal constatação é importante, pois, na nossa interpretação, além do fato de estarmos diante de uma voz "outra" presente nesses dizeres, a referida característica aponta para uma diluição de sentidos convencionados e socializados (entre professores-formadores e alunos) que fazem emergir a noção de constituição de um pacto tácito - por não ser intencional, articulado e consciente - sobre o adiamento da formação. Aspecto já discutido na seção anterior.

A "avaliação" da formação do aluno da instituição privada: "a FORMAÇÃO dele não é sólida" (excerto 30) nos leva a refletir que, por não ter sido suficientemente preparado para a vida profissional (“ó três anos... não bastou pra mim"), conseguindo "apenas" o diploma, o aluno conclui seu curso com um "desejo de buscar mais". Ou seja, depreende-se que o despertar de tal desejo pode e é, minimamente, assegurado, o que faz com que o desenvolvimento do aluno como professor esteja ainda por vir. Nessa perspectiva, P8 reproduz um enunciado que revela um desejo do aluno, uma busca pelo desenvolvimento profissional que fica prorrogado (“eu quero... me desenvolver”). Com esse dizer, obtém-se o efeito de que a formação de professores possui uma característica coadjuvante, suplementar, pois o fazer pedagógico relacionado ao desenvolvimento da capacidade crítica parece assumir 
uma função preliminar, aparentemente, desconectada do objetivo de formar professores. Criase um efeito de que a formação de professores acontecerá em um local outro. Ela passa a figurar, portanto, como uma promessa de realização que poderá se concretizar ou não.

Nossa análise sobre os excertos 29 e 30 nos faz retomar reflexões sobre a modernidade líquida de Bauman (2001). Para ele, o consumismo não se refere à satisfação das necessidades, mas ao "desejo", que define como uma entidade que tem uma natureza "muito mais volátil e efêmera, evasiva e caprichosa, e essencialmente não-referencial que as 'necessidades', um motivo autogerado e autopropelido que não precisa de outra justificação ou 'causa"' (p. 88). Com efeito, as formulações encontradas nos excertos 29 e 30 sobre os alunos parecem apontar para o despertar de uma vontade, um desejo que não é esclarecido. Conforme dizeres analisados, existe, nos alunos, o esboço de uma vontade de continuar seus estudos. Entretanto, não encontramos materializações lingüísticas e discursivas nos fragmentos analisados que justifiquem o desejo ou a vontade pela continuidade, algo como o despertar do interesse por uma determinada área de pesquisa ou qualquer outro aspecto, questão ou dúvida suscitada durante a formação. Há apenas referência ao continuar - sem causa aparente -, ou seja, é o "desejo que tem a si mesmo como objeto constante, e por essa razão está fadado a permanecer insaciável” (p. 88). ${ }^{114}$

\subsection{Considerações acerca da Instituição 1}

A fim de sintetizar a análise empreendida, neste capítulo, lembramos que a intenção era explorar como a ambivalência irrompe na dimensão do discurso didático-pedagógico em contextos educacionais. Ademais, a investigação procurou destacar as representações acerca da formação de professores de inglês em uma instituição específica. ${ }^{115}$ Havíamos postulado que há um modo de funcionamento discursivo que produz um efeito de adiamento da formação de professores de inglês. Ao longo da análise, portanto, buscamos evidenciar, no discurso, efeitos de instabilidade, de indeterminação, de não-fechamento de sentidos, obtidos por meio de determinadas formas lingüísticas e discursivas de dizer (a polifonia enunciativa, a

114 A esse respeito, lembramos que, conforme Usher e Edwards (1994, p. 11), o desejo está para a pósmodernidade, assim como a razão estava para a modernidade. Segundo esses teóricos, na pós-modernidade, há o prazer constante do desejo de experimentar (experiencing), pela simples justificativa do desejo em si, sem nenhuma outra razão.

115 Reiteramos que o mesmo procedimento será seguido no próximo capítulo, no qual a investigação estará voltada para a segunda instituição pesquisada. Esse e o próximo capítulo compõem a última dimensão na qual buscamos apontar as marcas daquilo que assumimos como ambivalência constitutiva. 
negação e a narrativização). Esse efeito de instabilidade, de incerteza, de indefinição de sentidos deve-se, particularmente, às reproduções de vozes diversas que ajudam a criar um discurso híbrido ${ }^{116}$ de imitações. No caso da representação da voz do aluno, o professorpesquisador é também interpelado como um conhecedor ou legitimador de tal voz. É esperado que, como professor-formador da Instituição 1, o professor-pesquisador dê anuência para as reproduções. Isso faz com que a cenografia seja também um elemento que propicia essa hibridização no discurso do professor-formador, sobretudo por tratar-se do gênero entrevista. Logo, a imitação da voz do aluno só é possível em virtude da confirmação ou da compreensão, por parte do professor-pesquisador, de que a representação enunciada é socializada e estabelecida como significativa dentro do contexto institucional.

Vimos, desse modo, na primeira seção, a construção de um perfil do futuro professor de inglês a partir da reprodução de vozes (inclusão de fragmentos estranhos à cadeia enunciativa), em forma de mini-relatos. Os fragmentos narrativos incluídos na enunciação sinalizam características negativas (ausência de preparo, interesse, maturidade, engajamento etc.). Há, então, a construção de um perfil de aluno que apresenta lacunas não apenas na formação anterior (Ensino Médio), como também após a formação profisssional no interior da Instituição 1. Essas lacunas dizem respeito, principalmente à competência lingüística, que entendemos não ter relação apenas com a proficiência da língua-alvo, mas também com a capacidade de ler um texto literário, bem como de escrever um texto. A ausência de conteúdos torna a formação de professores impossível no contexto analisado, pois cria-se uma hierarquia: primeiro a competência lingüística e a aquisição de conteúdos; depois, a formação de professor. Como a competência e os conteúdos são insuficientes, há um efeito de sentido de que a formação de professor é impossível. Entretanto, esse dizer impossível não se apresenta de forma explícita no discurso, ele se mostra "camuflado" por meio do efeito de tentativa de estabelecimento de um pacto (tácito) sobre a impossibilidade da formação. Há, nas materializações lingüísticas e discursivas, ou nos silenciamentos ${ }^{117}$, um efeito de anuência dos sujeitos envolvidos no processo da formação de professores de inglês, frente às “impossibilidades" enunciadas. ${ }^{118}$

\footnotetext{
${ }^{116}$ No sentido em que o termo é trabalhado por Bhabha (2007).

${ }^{117}$ No sentido que este conceito tem para Orlandi (1997).

${ }^{118}$ Nesse momento da análise, cabe retomar considerações feitas por Delibo (1999). O autor levantou um painel considerado "crítico" para a formação de professores de inglês. Quando apresentamos seu trabalho no capítulo Formação de professores, propusemo-nos a observar se encontraríamos quadro semelhante em nossa pesquisa. Após nossa análise, concluímos que alguns fatores apresentados pelo autor (tempo exíguo, ausência de conhecimento e preparo lingüístico) apresentam-se também aqui, no discurso, como elementos que
} 
$\mathrm{Na}$ segunda seção, então, partindo do pressuposto de que a concepção sobre a formação de professores de inglês tem seu sentido diluído, indefinido, distanciado, investigamos sinais no discurso que sugerem a constituição de um pacto tácito sobre a impossibilidade de formar um professor de inglês em face do contexto apresentado. Diante do quadro "impossível” apresentado: ausência de base, conteúdo, maturidade, falta de domínio na língua-alvo (no âmbito discente); restrições institucionais (carga horária, nivelamento) e esmaecimento didático-pedagógico (limitações e dificuldades dos professores-formadores) etc., a diluição do discurso provoca um efeito de impotência, de ausência de compromisso, de uma expectativa de que a "falta" possa ser complementada em momento futuro. Observamos que os fatores identificados acima (elementos "impeditivos" da formação) perpassam todo o discurso da formação, revelando, em vários momentos, um efeito de anuência, ora do aluno, ora do professor-formador, de que a formação profissional não se dará, enquanto os elementos apresentados como obstáculos não forem erradicados. Apontamos, então, no decorrer da análise, momentos pactuários ou marcas tácitas de compartilhamento da impossibilidade sugerida, implícita, camuflada - da formação em diversas instâncias: aluno/aluno, aluno/professor-formador, aluno/professor-pesquisador, professor-formador/professorpesquisador, professor-formador/instituição, professor-formador e ou aluno/“sistema”. Percebe-se no discurso um efeito de concordância, de consonância a respeito das dificuldades apresentadas em uma instância endógena (alunos, professores-formadores, instituição) como também exógena (enunciadores-genéricos ${ }^{119}$ ). Nesse caso, apontamos para os dizeres que tocaram na carreira profissional do docente, "obstáculos" da futura vida escolar (visão construída sobre a língua inglesa na rede oficial de ensino) e incertezas quanto à escolha da habilitação (investimento na língua inglesa ou portuguesa) etc.

Na terceira seção, por meio de uma categoria de análise que nomeamos "linearização", argumentamos que há um funcionamento discursivo que estabelece fases lineares que parecem tentar ordenar ou organizar as impossibilidades descritas anteriormente, priorizandoas de diferentes maneiras. Tem-se, então, um efeito de criação de demandas por parte dos professores-formadores envolvendo uma atitude de resgate (de interesse, conhecimento, postura etc.), de equiparação ou nivelamento para que se possa iniciar, a partir de um denominador comum, a formação para a vida profissional. Dada a impossibilidade de se

dificultam a formação de professores de inglês. Nessa mesma linha, incluímos o trabalho de Baghin-Spinelli (2003) que trata do "discurso da falta".

${ }^{119}$ Cf. Guimarães, 2005. 
estabelecer esse ponto de partida, em virtude de diversos fatores que apontamos (diferenças de nível de proficiência na língua-alvo, falta de interesse e comprometimento, limitação do tempo etc.), tem-se a impressão de que a opção é pela construção de uma formação basilar apenas. Entre a série de etapas estabelecidas pelos professores-formadores está o despertar da compreensão do aluno, de modo tácito, de que a construção do saber profissional está, de certo modo, sob a responsabilidade dele. Enfim, a contingência determinará o nível da necessidade de busca por essa formação. Os elementos que determinarão ou encaminharão esses alunos para uma "completa" formação estão vinculados ao contexto educacional/profissional nos quais estarão inseridos. Lembremo-nos, por exemplo, da visão compartilhada sobre o ensino público que foi (ou é) engendrada ou reforçada no interior do curso.

O efeito de ordenação de etapas parece restringir-se a condutas preliminares, preparatórias para algo que ainda está por vir. O modo como as atividades docentes são seqüenciadas faz emergir a noção de que a questão da formação de professores de inglês fica à margem de questões consideradas mais prementes, a saber: concepção de universidade e de aluno universitário (não definida), proficiência em ambas as línguas (inglês e português), homogeneização de nível de conhecimento da língua-alvo, despertar de valores morais e éticos (interesse, criticidade, reflexividade), preparação do professor-formador. A linearização sugere, então, um distanciamento da formação per se, pois os dizeres parecem priorizar a homogeneização de diferenças. Sendo assim, tem-se um efeito de que a formação poderá ocorrer somente quando tais diferenças forem "solucionadas". Ou seja, no discurso dos sujeitos investigados, a formação parece estar/ser desconectada, distanciada da situação "real" descrita. O efeito de valorização que se obtém com a descrição de uma série de procedimentos "introdutórios" na formação de professores torna a formação do professor de inglês postergada. As questões prementes e conflitantes apresentadas como "preliminares" se potencializam, deixando pouco ou nenhum espaço para a discussão de questões relacionadas à formação do professor de inglês - daí o efeito de adiamento da sua formação.

Em meio à linearização das atividades didáticas e pedagógicas, destacamos, em vários momentos da análise, o embate de perspectivas (dos professores-formadores e dos alunos) diante de um contexto que parece se caracterizar como um interregno. Em outras palavras, argumentamos como vimos algumas concepções da modernidade em confronto com noções da pós-modernidade. Essa transição de paradigma traz para a educação a necessidade da 
reformulação de conceitos (aula, aluno, professor, escola, formação etc.), os quais parecem estar pendentes de ressignificação. Não há, de modo explícito, formulações que postulem os papéis de cada um dos integrantes do contexto educacional. Não se sabe e não se diz, mas há um fazer concreto que se mostra à deriva, à espera de uma "reconfiguração"120. Para esse caso, é sugestiva a descrição seqüencial de procedimentos investidos sobre o aluno no sentido de "preparar o terreno" para a formação, atuando, primeiramente, sobre atributos éticos (um nível "pré”, portanto). Há, em seguida, uma valorização do conhecimento conteudístico. É um fazer que se apresenta, muitas vezes, dividido entre uma concepção educacional que totaliza, incorpora, integra, mas, ao mesmo tempo se desfaz, se fragmenta, se multiplica. Ou seja, a visão de professor (de um modo geral) é perpassada pelo discurso da modernidade que postula o domínio, o controle científico, a linearidade, a previsibilidade para poder exercer a função docente. Contudo, está presente também no discurso, a noção de que há o imprevisível, o incerto, o contingente (noções pós-modernas), características trazidas pelos sujeitos investigados que vão de encontro a determinadas representações já sedimentadas. Ao longo da descrição linear de etapas, notamos um efeito de reforço de algumas dicotomias (teoria/prática, por exemplo), como também vimos a irrupção de uma visão depreciativa da profissão docente. Além disso, criou-se um efeito dissociativo da formação com a exacerbação do pensamento crítico, como se aí não houvesse espaço para se pensar sobre a formação de professores de inglês.

Em suma, as diferentes formas de manifestação da polifonia, presentes nos discursos dos professores-formadores e dos alunos, nos dão a impressão de que o perfil desse futuro profissional apresenta uma constituição marcadamente dependente. A sobreposição de vozes (do colega, do professor-formador, de um outro alguém) inserida na cadeia discursiva causa um efeito de dependência entre os dizeres. Entendemos que todo discurso é fragmentado, diluído entre diversas vozes, marcas lingüísticas e discursivas que remetem a um outro. No entanto, considerando que o perfil do futuro profissional está imbricado por uma rede de significações que revela, mas também se camufla, que se constitui e se dilui, em última análise, tal perfil mostra-se atrelado a uma significação futura, contingente, à mercê das possibilidades que a carreira profissional apresentar. Desse modo, do ponto de vista da formação do professor de inglês, nesse contexto analisado, ela se constituirá, à medida que as contingências da vida profissional lhe atribuírem responsabilidades.

\footnotetext{
${ }^{120}$ No sentido em que o termo é usado no universo da informática.
} 


\title{
CAPÍTULO 6
}

\section{AS DUAS FACES DO TRAUMATRÓPIO: ${ }^{121}$ O DISCURSO DA FORMAÇÃO DE PROFESSORES DE INGLÊS (INSTITUIÇÃO 2) ${ }^{122}$}

\begin{abstract}
A verdade não pode estar diante de nós - não pode existir independentemente da mente humana - porque as frases não podem existir dessa maneira ou estar diante de nós dessa maneira. O mundo está diante de nós, mas as descrições do mundo não. Só as descrições do mundo podem ser verdadeiras ou falsas; o mundo por si próprio - sem auxílio das atividades descritivas dos seres humanos - não pode.

Richard Rorty. Contingência, ironia e solidariedade.
\end{abstract}

Neste capítulo, trazemos resultados da pesquisa realizada numa instituição de ensino superior, pública. Nela, realizamos 11 entrevistas, sendo seis com alunos do curso de licenciatura da Faculdade de Educação dessa universidade e cinco com professoresformadores do mesmo curso. À época da pesquisa, dos seis alunos selecionados, quatro já possuíam o bacharelado em letras, habilitação em inglês e dois eram concluintes do mesmo curso. No curso de licenciatura da Instituição 2, os bacharéis em letras não são divididos de acordo com suas especialidades, nas disciplinas iniciais oferecidas. Tal divisão ocorre apenas para a disciplina de Metodologia do Ensino. Desse modo, ao longo da análise, quando não houver referência específica sobre os bacharéis em letras, especialistas em inglês, a referência a "alunos de letras" contempla especialistas em português ou outras línguas estrangeiras, tais como: francês, espanhol, italiano, alemão etc.

No presente capítulo, dividido em seis seções, voltamos nosso olhar para um funcionamento discursivo que produz efeitos de "associação" e "dissociação" nas representações sobre: a) o aluno, futuro professor de inglês; b) o instituto no qual ocorreu sua graduação (bacharelado); c) o professor-formador; d) o instituto que prepara o aluno para a carreira docente (educação) e e) o curso de licenciatura. Esses modos enunciativos ajudamnos a detectar no discurso, efeitos agregadores, associativos, por um lado, mas, por outro lado,

\footnotetext{
${ }^{121}$ Brinquedo óptico composto de um pequeno disco com desenhos diferentes impressos em cada um dos lados. À medida que o círculo é posto em movimento, os dois desenhos se fundem numa única imagem.

${ }^{122}$ Por razões éticas, esse é o modo que adotamos para nos referir à segunda instituição pesquisada.
} 
pela própria ambivalência da linguagem (BAUMAN, 1999a), acabam por mostrar formas desagregadoras e fragmentadas no discurso da formação de professores.

\subsection{Em busca do amadurecimento necessário}

O primeiro aspecto que levantamos diz respeito ao perfil dos alunos de letras, característica trazida por quatro professores-formadores, dos cinco entrevistados. Comecemos pelo trecho que se segue:

Excerto $31 \quad$ P2: [...] nas turmas que eu tenho concentração de alunos que vêm das turmas de letras... é muito interessante como eles lidam com a palavra... gosto muito... e procuro evidenciar e procuro ressaltar o domínio... o domínio da palavra né... da palavra... falada... da palavra escrita... isso me parece muito interessante... e eu... identifico... eu reconheço e eu valorizo... [...] escrevem bem... se colocam bem... domínio de linguagem... isso é o que me salta muito... não me salta/o que não me salta muito neles é a questão... eu acho que... da politização que eu vejo mais nítido no pessoal de ciências sociais... geografia... história... [...] o pessoal que faz história... geografia... ciências sociais... filosofia... eles têm uma visão mais politizada da educação... muito mais politizada... muito mais engajados... têm uma visão crítica da realidade... têm uma concepção crítica em relação ao modo de produção capitalista... as contradições do mundo capitalista... o que eu noto menos nos alunos que vêm... da área de letras né... pelo menos... eu não tenho isso empiricamente para demonstrar mas é intuitivo...

Notamos, no excerto acima, reflexos de uma concepção cristalizada sobre o curso de letras, que também ecoam nos discursos analisados, no capítulo anterior. Apontamos, naquele momento, algumas visões que se conflitavam, colocando em cena ideais modernistas (domínio da palavra, da linguagem etc.) frente a um conjunto de fatores (emergidos com a pós-modernidade) que "desarmonizavam" a pretensa estabilidade daquelas características. O efeito que obtivemos foi de uma tentativa de equiparação das "discrepâncias" por meio de um processo de linearização, que buscou nivelar subjetividades, interesses, conhecimento para, posteriormente, abordar a formação de professores de inglês.

No excerto 31, os alunos de letras emergem da cadeia discursiva como sendo um elemento diferente (não são politizados), provocando um efeito de dissociação no discurso. A visão sobre os alunos de outras áreas diversas (ciências sociais, geografia, história, filosofia) parece ser uma padronização, por apresentar-se constituída em um grupo mais amplo, cujas características são semelhantes. Tal modo de dizer faz com que os alunos de letras se 
constituam em um grupo desvirtuado, divergente, pois sua descrição ocorre de forma a destacar um elemento subtraído (efeito obtido por meio do advérbio "menos" nas expressões comparativas). Ou seja, tem-se a impressão de que, com exceção dos alunos de letras, os outros grupos apresentam patamares necessários ou adequados para se trabalhar com a formação.

Encontramos formulações parecidas com relação à característica prototípica dos alunos de um curso de letras no excerto a seguir. Do mesmo modo, aparece um elemento outro na enunciação ("eles não debatem") que parece não se coadunar com os requisitos necessários para se discutir a questão da formação. Vejamos um pouco mais da enunciação:

Excerto 32 P3: [...] o pessoal de letras é muito... disciplinado... lê tudo... fala pouco... lê muito... não está acostumado a debater... é uma coisa que talvez venha lá da origem... são muito quietinhos... [...] eu to falando uma coisa assim que não é baseado muito... em observações muito organizadas né... o que eu me lembro assim... eu gosto muito deles porque eles são disciplinados... porque eles lêem tudo o que você pede... se você pede fichamento... eles fazem... na hora de participar fazendo... problematizando o texto eles vão... cumprem a tarefa... mas falam pouco... participam pouco no sentido da crítica... no sentido de se expor... eu tenho impressão que... eu tenho IMPRESSÃO ... não sei... eu já conversei um pouco com eles... "ó pessoal de letras... fala aí um pouco... vocês são..." eu brinco com eles... "vocês são os escritores... têm que falar..." e eles... éh::: alguns afirmam que eles não têm muito essa prática na unidade... isso dá para perceber claramente... então eles ficam fascinados quando você abre espaço...

No excerto 32, emerge uma sugestão de que a falta de predisposição para a discussão é algo que se deve à formação específica. Isto é, o perfil do aluno de letras parece ser constituído de uma forma tal que não se valoriza um aspecto necessário para sua formação como professor ("alguns [alunos] afirmam que eles não têm muito essa prática [debater, criticar] na unidade"). Assim, com esse outro excerto, notamos que se esboça um aluno de letras cujo traço mais característico (prática de leitura) parece não ser relevante para sua formação como professor. Existem, ainda, atributos a serem despertados, como, por exemplo, um posicionamento crítico. Ainda com relação à materialidade lingüística, notemos como a formulação "eles [alunos de letras] ficam fascinados quando você abre espaço" faz ecoar uma representação fundamentada na perspectiva da modernidade que preconiza a emancipação do indivíduo a fim de exercer sua subjetividade, conforme discutem Usher e Edwards (1994, p. 24). Nessa linha de raciocínio, Popkewitz (1998, p. 4) também postula que o fato de "dar voz" (“abrir espaço", no segmento analisado) está pautado na crença de que por meio de tal atitude, 
há possibilidade de promover a "inclusão" dos "excluídos". Julgando por esse efeito de sentido de exclusão dos alunos de letras, evidencia-se, no discurso, uma imagem desses alunos iniciando sua formação com um traço de desvantagem. Vejamos outro momento da enunciação de P3:

Excerto 33 P3: [...] só tem essa característica... eles participam... eles se entrosam bem... eles são receptivos... eles são amáveis... eu não tenho NADA contra eles... só acho que eles são quietos demais e a reivindicação que eu faço é que::: precisa pensar um pouco na relação... que::: ... como é que se dá a relação pedagógica lá né... acho que é um pouco massacrante né... eu acho que nós temos que nos preparar... [...] eu acho que a ((citou instituição 2)) tem que se democratizar... mas já devia ter um curso... um ano básico sabe... porque::: [...] eles se sentem muito fragilizados... porque na letras... eu não sei como é o curso de letras... eu não sei... se todo mundo é do mesmo tipo... se tem os mais... eu não sei como eles trabalham... como é que os professores também vêem... eu nunca conversei... eu tenho um colega que é de lá... mas nunca trabalhei essa questão... acho que é isso... está havendo um esforço da licenciatura hoje de se aproximar dos cursos das unidades né... das áreas... e::: mas ainda não compreendi muito bem a... dinâmica...

Nesse momento da enunciação, a relação pedagógica na unidade de letras é apresentada como causa da falta de amadurecimento crítico para a formação docente do aluno de letras. Emerge, então, do discurso, a questão pedagógica como efeito de solução para agregar valores ao aluno de letras. Entendemos que podem estar incluídos em tal relação aspectos, como: currículo, procedimentos didáticos, interação professor e aluno, entre outros. Mas o fato que queremos realçar diz respeito à "reivindicação" proposta por P3 e o efeito de resgate, de recuperação de alguma qualidade "perdida" ou ainda não construída devidamente. Com tal reivindicação, há uma sugestão de que a falta trazida para o espaço "formação de professores" pelos alunos de letras deve ser complementada na própria unidade de origem dos alunos. No entanto, surge, na enunciação, um efeito de imprecisão com relação a tal complementação, pois o sujeito desconhece o curso de letras ("eu não sei como é o curso de letras"), fato que torna sua reivindicação puramente retórica. Há uma falta descrita que deve ser completada a partir de um viés pedagógico. Essa "complementação" ou "reparo" pedagógico está sob a responsabilidade de quem, afinal? Pelo fio discursivo, concluímos que o traço a ser resgatado no aluno de letras está vinculado ao estabelecimento de uma relação de maior proximidade entre as duas unidades: letras e educação ("está havendo um esforço da licenciatura hoje de se aproximar dos cursos das unidades"). Ao final da enunciação, tem-se o efeito de que não depende apenas de uma delas, mas da criação de um mecanismo que as aproxime, pois a responsabilização por esse resgate parece estar distribuída entre elas. 
Lembramos que expusemos, anteriormente, exigências legais ${ }^{123}$, nas quais encontramos orientação para que os cursos de formação de professores promovam maior articulação do saber específico com o saber pedagógico. Acerca de tal propósito, cabe destacar trabalho de Guimarães (2004), apresentado no capítulo Formação de professores. O autor afirma que na Universidade Federal de Goiás, local onde realizou sua pesquisa, a partir da "transferência" de algumas disciplinas, antes ministradas pela Faculdade de Educação, para os institutos específicos (Letras e História, no caso da sua pesquisa) tal articulação proporcionou o "surgimento de atitudes mais positivas em relação ao formar professor" (p. $80)$.

A diversidade em termos de formação e expectativas com relação à educação emerge também do segmento abaixo (excerto 34). Segundo P4, como a grande maioria vem de programas de formação mais conservadores, temas como a renovação da escola, a busca por uma pedagogia mais interessada, que leve o aluno a ser um sujeito mais ativo, mais crítico, muitas vezes, não são compreendidos, pois os alunos não passaram por escolarização semelhante. Vejamos um pouco mais sobre os alunos de letras:

Excerto 34 P4: [...] são alunos mais preparados para o estudo... mais habituados com a leitura... me parece né... [...] alguns chamam a minha atenção porque são atualizados... assim... conseguem fazer... relações interessantes com diferentes campos... [...] falam de pesquisas muito recentes... [...] o pessoal de letras assim como história... ciências sociais costumam fazer análises mais densas e apresentar relatórios melhores elabora/mais... acho que redação melhor do que outras áreas do saber como essas que falei... matemática... biologia... são textos... são alunos que cuidam melhor do texto... são alunos que têm uma redação acho que mais... sólida... mais... mais fluida... [...] eu acho que::.: éh::: assim::: eu sinto um certo despreparo para discutir questões educacionais ((pausa longa)) ... mas isso é meio geral assim... não é restrito ao pessoal de letras né... mas eu acho que assim... há uma certa::: éh::: ((pausa longa)) ... imaturidade... uma certa ingenuidade quando trata de algum tema mais ligado ao mundo educacional... um certo despreparo... eu sinto... né... mas... nada que difira tanto dos outros né... é meio geral isso... exceto quando esse aluno já é professor... já está mais envolvido né... isso é um dado assim... são pessoas menos curiosas eu acho... menos interessadas em aprofundar... temas da educação... quer dizer... ficam mais circunscritos ao seu campo de interesse... me dá um pouco essa impressão... mas... um ponto a favor é que gosta muito de ler... então isso é bom né... o fato de ler... de consumir muita literatura... de conhecer os clássicos... acho que dá uma visão de mundo mais aberta... mais ampla né... mas frágil no campo educacional... é isso...

${ }^{123}$ Cf. Brasil, 1996 e 2001; Conselho Nacional de Educação / Conselho Pleno, 2002a e 2002b. 
O aspecto que detectamos nos excertos 31,32 e 33, com relação à visão cristalizada do curso de letras, volta a aparecer no fragmento acima (excerto 34). Do mesmo modo, desponta também a questão do "preparo", ou a falta dele, para a inserção do aluno no campo educacional. Despertamos, novamente, a partir dos fragmentos expostos, para o efeito de estabelecimento de uma etapa prévia para a formação docente. Por meio dos substantivos "imaturidade", "ingenuidade" e "despreparo", temos a sensação de que a formação de professores está condicionada a uma etapa preliminar, na qual há um investimento no "resgate da alma" do aluno, conforme visão crítica de Popkewitz (1998). No excerto 34, há dizeres que agregam valores aos alunos de letras: cuidado com o texto, solidez na redação, visão do mundo "ampla e aberta", que são semelhantes aos apontados nos excertos 31, 32 e 33 (domínio da palavra, disciplina, hábito de leitura etc.). No entanto, há algo que lhes falta. Essa falta não parece ser "empecilho" para a formação docente, mas julgando pela formulação “exceto quando esse aluno já é professor", tem-se um efeito de que a preparação docente não ocorre durante o curso de licenciatura, mas sim após tal período, quando o aluno já está exercendo/assumindo o papel de professor. Ou seja, há o efeito de uma naturalização de que a formação de professores se dá efetivamente no exercício da profissão.

A formulação trazida no início da enunciação sobre a preparação para o estudo e o conhecimento sobre "pesquisas recentes" provoca um efeito associativo/dissociativo acerca da representação do sujeito "aluno de letras". O interesse pela leitura, apontado como "um ponto a favor", assim como a atualização acerca de pesquisas ajudam a esboçar um perfil que, basicamente, possui características contrárias, adversas àquelas necessárias para a formação de professores. Não encontramos evidências discursivas de que as características "positivas" destacadas nos alunos de letras sejam importantes para sua formação docente. Há um efeito associativo, agregador para a vida do aluno, mas tal característica parece não contribuir para o campo educacional, ou parece estar dissociada da perspectiva educacional. Cabe interrogar em qual momento da vida escolar dos futuros docentes deve ser despertado o "interesse", a "curiosidade" por temas educacionais, uma vez que tais atributos lhes faltam.

Os segmentos apresentados até o momento (excertos 31, 32, 33 e 34) esboçam a constituição de um “duplo”, conforme contribuição de Popkewitz (1998, p. 41). Segundo esse autor, a partir de um pólo "normal" assumido e não problematizado, o olhar do professor cria um segundo pólo de ausência a ser resgatado no aprendiz. É nesse espaço entre pólos que se 
dá a agência ${ }^{124}$ do professor para promover a "redenção pessoal" do aluno. A visão crítica desse pesquisador nos faz enxergar, nos segmentos até aqui analisados, um funcionamento discursivo que sinaliza a constituição de um duplo. Os alunos provenientes de áreas, tais como: geografia, história, ciências sociais estão em um pólo tomado como "normal" esperado, pois não há problematização acerca das características de tais alunos. A partir desse primeiro pólo (alunos de outras áreas), cria-se um duplo, no qual os alunos de letras apresentam-se com ausências de atributos, os quais, em tese, "serão resgatados" pelo professor-formador. Ou seja, a ausência é discursivamente construída, "dissecada e reclassificada", nas palavras de Popkewitz (1998, p. 44), criando um objetivo de ensino. Entretanto, como tal ausência é construída pelo olhar do professor-formador (nesse caso), assim como o atributo "normal" do primeiro pólo é também uma construção socializada, instaura-se a impossibilidade de transformar os atributos dos alunos de letras (segundo pólo) na média, ou no pólo "normal”.

Com efeito, os segmentos apresentados nos sugerem a presença de um já dito (interdiscurso) que se materializa por meio de enunciados socialmente construídos: "alunos de letras escrevem bem”, “dominam a língua(gem)", “são bons leitores”, “gostam de ler” etc. Foucault (2007, p. 115) nos diz que os enunciados possuem um "regime de materialidade repetível”. Em outras palavras, esses dizeres pertencem a um imaginário discursivo que retornam e, ao retornarem, se firmam e se socializam como verdades naturais, assumidamente “normais". É a partir desse repetível que se constrói um duplo, conforme esclarece Popkewitz (1998). De modo similar, se invertermos os pólos, podemos notar - no discurso - a mesma impossibilidade de fazer com que alunos de outras áreas (geografia, história, ciências sociais etc.) sejam bons leitores, dominem a língua(gem) etc. Como esse espaço jamais deixará de existir, a questão que se impõe, então, é indagar sobre a legitimidade de nortear a formação a partir de um resgate que nunca se completará.

A fim de ilustrar aspecto que mencionamos acima com relação ao preparo para a formação docente durante o exercício da profissão, olhemos para o segmento abaixo:

Excerto 35 A1: o curso de licenciatura para mim... em inglês éh::: metodologia foi uma surpresa... porque eu não imaginava que houvesse tanta ciência em dar aula... para mim era só chegar na aula abrir o livro e simplesmente abrir a boca e dar gramática né... no caso era o que eu fazia já há três anos numa ONG... [...] e

${ }^{124}$ Utilizamos o termo "agência", conforme trabalhado por Bruner (2001, p. 41), para indicar a capacidade individual de iniciar, concluir e avaliar nossos atos, implicando, com isso, "habilidade e know-how" para concretizá-los. 
era muito prático porque... inclusive eu era tida como uma excelente professora porque seguia o método... seguia o livro [...] eu nunca pensei que houvesse um planejamento assim... eu sempre pensei que era um dom que a pessoa tinha... que punha o pezinho na sala de aula... baixava um santo... um professor... e aí ele se transformava num bom professor de inglês [...] eu acho que eu dei muita sorte... eu tive... excelentes professores na licenciatura... como essa é minha segunda licenciatura né... de fato a terceira porque eu faço português inglês... eu já havia feito a licenciatura em ciências sociais... [...] a coisa é::: talvez eu não tivesse maturidade suficiente para juntar tudo aquilo que eu aprendi nas diversas disciplinas da licenciatura... num (corpo) de ser professor... como eu me vejo professora com toda essa bagagem... eu não consigo fazer essa transição entre... todo esse conhecimento e o que eu posso fazer numa sala de aula... de fato é uma coisa que... não me passou ainda... pela cabeça... eu só estou tomando consciência dessa postura de ser professor... agora nessa licenciatura... de letras né...

Conforme apontamos no excerto 34, o "preparo" necessário para discutir temas educacionais parece estar vinculado ao efetivo exercício docente ("exceto quando esse aluno já é professor"). De fato, se tomarmos o fragmento acima (excerto 35), o primeiro curso de licenciatura só passa a produzir significados após um período de trabalho como professor e início de uma segunda licenciatura. Do ponto de vista da materialidade lingüística, a expressão retificadora "de fato a terceira" e as palavras denotativas "só" e "agora" realçam o efeito de uma compreensão "tardia" sobre o curso de licenciatura. Com isso, o efeito de sentido que subjaz ao excerto é de que a "compreensão" do trabalho docente ocorre de forma aleatória, intuitiva, como conseqüência de um insight. Desse modo, na nossa interpretação, inscreve-se no discurso uma representação sobre a formação docente como um ato contingente, pois se anula a possibilidade de produção de sentidos durante o curso de formação, por estar atrelada a uma região desconhecida da intuição, da incerteza, do porvir. Cria-se com esse discurso uma imagem da docência como fruto de uma experimentação, resultado de sucessivas tentativas a fim de se obter a "compreensão" do que significa a formação e o tornar-se professor.

Na cadeia discursiva, surgem, também, algumas concepções sobre o ensino de inglês, merecedoras de reflexão. Primeiramente, a questão do percurso profissional do professor de inglês. A1 inicia preparo para sua carreira após já ter lecionado língua inglesa. ${ }^{125}$ Ou seja, identificamos um movimento que descreve o ingresso na carreira profissional de modo circunstancial, fato que julgamos ser recorrente na área. Lembramos, aqui, pesquisa de Monte

${ }^{125}$ Conforme estudo da UNESCO (2004, p. 83), realizado com 5.000 docentes brasileiros do ensino fundamental e médio, em escolas públicas e privadas de área urbana, $53 \%$ dos professores iniciaram a carreira docente antes de concluir o curso de habilitação. 
Mór (2006) sobre a função educacional da língua inglesa e a maneira pela qual alguns docentes ingressam na profissão. Para a autora, muitas vezes, a escolha profissional deve-se a fatores sociais como, por exemplo, a falta de oportunidade no mercado de trabalho. Com isso, é possível encontrarmos um quadro, no qual muitos profissionais ingressam no magistério por possuírem conhecimento da língua inglesa; fruto, às vezes, de uma vivência em um país onde o inglês é primeira língua ou da preparação em cursos de línguas em escolas de idiomas.

Outro aspecto com o qual nos deparamos, no segmento acima (excerto 35), diz respeito a uma concepção de educação, com raízes nos ideais modernistas, na qual o professor tem papel central. ${ }^{126}$ Nessa visão, há a exclusão do aluno e do professor como produtores de conhecimento, pois se destaca, sobretudo, o papel do material didático ${ }^{127}$ como fonte única de saber. O professor é mero reprodutor do saber pronto e acabado, seu papel resume-se, então, a transmitir tais conhecimentos, estando o ato de ensinar centrado somente nele. Emerge também do discurso uma visão de domínio da língua por meio do controle e aprendizado de suas regras gramaticais, crença bastante recorrente entre alunos de letras, conforme apontado em estudo de Barcelos, Batista e Andrade (2004). O recorte acima (excerto 35) parece capturar o sujeito em um momento de estranhamento, de questionamento de visões, pois parecia identificar-se com o papel do professor de inglês como seguidor de regras e métodos, dotado de um "dom" para ensinar. Entretanto, tal visão passa a ser questionada após um determinado período de trabalho docente e ao deparar-se com um elemento outro (um novo curso de licenciatura). Desse modo, o segmento acima provoca um efeito de que a formação depende de um retorno à universidade como uma maneira de possibilitar o despertar da compreensão acerca do papel do professor. Notemos o efeito provocado por meio do vocábulo "transição" que sugere uma transformação ou uma tradução do conhecimento acadêmico como resultado de um retorno à universidade, como o fechamento de um círculo.

Conforme argumentamos acima, no discurso dos professores-formadores, a formação específica do aluno de letras, vista de uma perspectiva educacional, parece se apresentar de modo lacunar. Emergem, então, do discurso analisado, dizeres que sugerem ações reparadoras

\footnotetext{
${ }^{126}$ Lembramos que, em momentos anteriores da análise, apontamos características da modernidade permeando o discurso da formação de professores.

127 Sobre esse tema, lembramos trabalho de Coracini (1999a), no qual vários autores lançam um olhar crítico sobre o livro didático, questionando seu modo de funcionamento e seus efeitos de sentido provocados na sala de aula. Apontam, por exemplo, para a maneira como algumas atividades de leituras em livros didáticos não permitem a produção de "novos" sentidos. Problematizam, também, certas atividades propostas, nas quais vêem a hierarquização da interpretação, estabelecendo (ou reforçando) com isso, relações de poder e legitimando verdades absolutas.
} 
para despertar o interesse educacional, ocorrendo um efeito de adaptação ou transposição do conhecimento específico para o educacional. No próximo segmento (excerto 36), por exemplo, há formulações que indicam uma falta de clareza sobre os objetivos do curso de licenciatura, por parte dos alunos, em geral. Ao traçar o perfil inicial do grupo, no início de cada semestre, P2 propõe que alunos escrevam um texto, explicitando como a licenciatura entrou no projeto de vida de cada um. Isso, para os alunos, causa um "embaraço inicial, causa certo constrangimento", pois, segundo P2, o curso de licenciatura, para os alunos, não é um projeto de vida. O texto produzido passa, então, a funcionar como "fio condutor" do curso, sobre o qual se busca fazer inserções pedagógicas. A partir do texto inicial, começa um processo de reescrita e constantes articulações com o conteúdo da disciplina, com a educação, mas, sobretudo, com a questão do "projeto de vida" de cada aprendiz. Vejamos o fragmento:

Excerto $36 \quad$ P2: [...] esse movimento [processo de reescrita] percorre todo o curso de licenciatura como percorre o curso de pedagogia... que é o projeto de vida... então os conteúdos discutidos ((citou exemplos)) ... sob a ótica de diferentes autores mas sempre numa perspectiva considerada crítica né... e eu sempre vou fazendo ganchos e articulações com esse projeto de vida... tem sido interessante porque ao final os alunos avaliam positivamente... dizendo "olha eu nunca tinha pensado nisso não é" ... e eu articulo... "olha você precisa ter nas suas mãos o seu projeto da vida... porque se você não tem um projeto alguém terá por você... o seu pai... a sua mãe... o estado... ou o seu empregador não é... então é importante que você tenha esse projeto... que esse projeto oriente as suas escolhas com maior clareza... com uma aguda consciência crítica nas suas escolhas no mundo pessoal e profissional"... e é interessante também que nessa questão do projeto de vida eu articulo a pessoa... o profissional e o institucional... porque geralmente eles não estão muito acostumados (com) a discussão da pessoa dele... a pessoa não conta muito né... e eu valorizo muito a pessoa dele né... porque uma parte importante dessa pessoa vai ser o professor... e essa pessoa e esse professor trabalharão numa determinada instituição... num determinado tempo e espaço...

Identificamos, nas formulações acima, a descrição de um procedimento voltado a propiciar um amadurecimento do aluno para a docência. Cria-se, com o modo de dizer, um efeito de redenção como parte de um fazer pedagógico estratégico para promover autoreflexão, crescimento moral e autogestão. Conforme já apontamos em outro momento da análise, essas são características daquilo que Popkewitz (1998) denominou como "resgate da alma". Esse autor aponta ainda que "a busca da alma deriva de uma tradição messiânica de redenção especificamente ocidental" (1999/2000, p. 146). De fato, há no discurso a exploração de uma região de sentido (interdiscurso) que se aproxima do discurso eclesiástico. Não estamos questionando as articulações didático-pedagógicas passíveis de ocorrer a partir do movimento descrito, nem nos interessa o modo como elas são realizadas. Enfatizamos a 
maneira como os dizeres parecem estar voltados, sobejamente, para um investimento no amadurecimento do aluno. Já vimos, em outros momentos da análise, formulações que insinuavam uma concepção do papel do professor como redentor. Percebemos também o mesmo efeito no trecho acima analisado. Contudo, surge, na seqüência, a constituição de uma hiância entre a formação específica (letras) e a licenciatura, figurando como terreno da incerteza, da imprecisão, da contingência. Emana do discurso da formação de professores um propósito implícito de agir, primeiramente, no "preenchimento" desse intervalo. Há, desse modo, um efeito de imprecisão na formação docente, em virtude da ausência de marcas lingüísticas e discursivas precisas sobre o surgimento dos resultados dessa atitude de resgate.

Considerando a existência de um processo de escolarização no qual houve a cristalização da figura do professor como central e entendendo também que os resultados de tal visão perpassam os discursos de professores e alunos no universo acadêmico, é, no mínimo, precipitado supor que uma disciplina ou um curso isolado dêem conta de transformar uma visão "ingênua e imatura" em crítica e comprometida com a educação. Nosso interesse não é desqualificar fazeres pedagógicos, pois acreditamos nas soluções locais para realidades e dificuldades específicas e contextuais. Nossa intenção está voltada para o efeito de valorização do "resgate da alma" na cadeia discursiva, provocando um esvaziamento ou embaciamento da formação docente, por meio de fazeres lineares, como se a formação pudesse acontecer em algum momento da seqüência.

Nessa mesma linha, olhemos para outro aspecto recorrente no discurso dos professores-formadores com relação ao despertar do senso crítico. Examinemos, primeiramente, os três fragmentos abaixo:

Excerto 37 P3: [...] uma outra coisa que eu faço... que eu dou uns temas de sugestão... é fazer com que ele [aluno] leia o jornal... então ele é obrigado e ler o jornal... com freqüência... eu falo todo dia... mas é com freqüência... e levantando as matérias sobre educação... revistas... ((citou nomes de jornais)) ... na imprensa em geral... e depois a partir dessas leituras eles também vão ficando mais sensíveis a temáticas para pesquisar... então... depois no final do semestre eles têm uma... prova conjunta para avaliar... a perspectiva da imprensa sobre as questões educacionais e tendo como contraponto o que eles viram no curso... então eu tenho muito essa preocupação de desenvolver um pouco a crítica... de conseguir fazer com que eles superem... principalmente... os alunos que vêm de outras áreas... o senso comum... 
Excerto 38 P4: [...] eu faço um trabalho de sensibilização na verdade inicial... para a problemática educacional que existe lá fora... no país que a gente vive... que nem todos estão... devidamente sensibilizados para o fato de... que é ocupar esse lugar (que esse aluno) num curso de licenciatura numa unversidade pública? ... se preparando para ser professor... coordenador... diretor de uma escola brasileira né... ou atuar em instituições ou fundações não importa exatamente onde ele vai atuar mas o campo da educação está muito complicado no Brasil né... e aí eu procuro logo no começo do curso trazer dados mais estatísticos... artigos de jornais que falam dos problemas... da realidade brasileira que nem todos têm... a devida consciência né...

Excerto 39 P5: [...] a finalidade não é que eles dominem esse ou aquele autor... essa ou aquela obra... tal ou qual teoria... inversamente... é que eles coloquem problemas... que eles debatam a respeito desses problemas... que eles consigam... formar um juízo... constituir um juízo fundamentado a respeito desses problemas... e para isso os subsídios... e outros subsídios são... pessoas que nós/que eu convido/sugiro para trazer... procuro fazer com que pessoas que têm... certas experiências... algumas práticas... que têm mais afinidade com as temáticas... que venham fazer uma breve apresentação... oral... e conversar com a turma a respeito... concretiza um pouco mais... como exemplos de esforços... empenhos... naqueles campos temáticos... que têm sido abordados... diretoras de escolas... professoras de escolas estaduais... às vezes são ativistas sindicais...

Nos três segmentos apresentados (excertos 37, 38 e 39), a conduta "reparadora" voltase para a questão da sensibilização e do desenvolvimento crítico do aluno. Ambos os objetivos parecem possíveis por meio da leitura constante sobre temas educacionais na mídia, ou por meio da participação de agentes externos ao contexto imediato (outros professores, diretores de escolas estaduais etc.). Ou seja, o despertar da consciência crítica depende de um elemento "outro" (outra fonte, outro recurso, outra pessoa), o qual tornará o aluno mais "consciente", mais "sensibilizado" ou com juízo mais "fundamentado". ${ }^{28}$ Conforme nos lembra Coracini (2003b, p. 282), "se a língua é o lugar do equívoco e se o sujeito é múltiplo, cindido, inconsciente, não é possível falar de autonomia e de consciência como ideais a serem perseguidos sem incorrer em falácias e engodos" (grifo nosso). Nos trechos apresentados (excertos 37, 38 e 39), fica estabelecido que para iniciar a formação docente, é necessário alcançar consciência, ter sensibilidade e espírito crítico. Assim, considerando contribuição de Coracini, acreditando na impossibilidade de tornar a conscientização e a criticidade mensuráveis, e, sobretudo, na complexidade do processo de leitura (temas educacionais na mídia - excertos 37 e 38), julgamos que o nível do "resgate da alma" operado nas

\footnotetext{
${ }^{128}$ No mesmo estudo da UNESCO (2004, p. 108), anteriormente citado, as duas mais importantes finalidades da educação apontadas foram: formar cidadãos conscientes e desenvolver a criatividade e o espírito crítico. Com efeito, lembramos que nos discursos dos professores-formadores analisados no capítulo anterior, assim como nas Diretrizes Curriculares, tais noções figuram como prioritárias na questão da formação de professores. Naqueles momentos, apresentamos alguns efeitos de sentido veiculados por tais conceitos.
} 
formulações acima (desenvolver a crítica, tornar sensível, ter consciência/juízo fundamentado) parece inscrever-se no espaço do acaso, do contingente. Do ponto de vista educacional, não acreditamos na possibilidade de criação e adoção de mecanismos que possam garantir o alcance de atributos tão abstratos sem incorrer em armadilhas tautológicas e efeitos retóricos. O efeito de investimento no despertar desses atributos parece se aproximar daquilo que Popkewitz (1999, p. 18) classifica como a democratização do indivíduo, fruto de uma modernização na educação, cuja meta era fazer com que as pessoas fossem vistas e se vissem como indivíduos capazes de agir no mundo. Podemos extrair daí uma imagem de transferência de responsabilidade pela formação, condicionada ao despertar de tais valores (consciência crítica, sensibilidade). No nosso entender, tal responsabilização parece eximir a agência do professor-formador, pois além de acreditarmos na impossibilidade de averiguar como e se tais atributos são apreendidos, não há materializações lingüísticas e discursivas que apontem para tal apreensão de valores.

Novamente, cabe reiterar que não estamos pondo em xeque o fazer educacional. Nossa intenção é chamar a atenção para o fato de certos dizeres sobre a formação docente serem formulados de modo a torná-la inalcançável. Há um funcionamento discursivo que parece prorrogar incessantemente a formação, ora por meio da polifonia enunciativa, da narrativização (capítulo anterior), ora pela remissão a ações e condutas "ideais” para capacitar o aluno, antes de habilitá-lo. Pensando, ainda, como o papel do professor, do material didático e da escola são historicamente sacralizados, é possível pensar em garantias de conquista ou aquisição de consciência, criticidade, sensibilização no trato com questões educacionais? Basear a formação docente em conceitos que, ao serem formulados, produzem efeitos contínuos de não-fixação de sentidos não é produzir nesse discurso um efeito de prorrogação da formação?

\subsection{A incerteza das escolhas profissionais}

Nesta seção, nosso objetivo volta-se para a questão do ingresso na vida profissional docente, do aluno do curso de letras. $\mathrm{Na}$ seqüência dos excertos expostos abaixo, reconhecemos na cadeia discursiva um movimento associativo/dissociativo similar ao que apontamos na seção anterior. Na análise mostrada acima, buscamos evidenciar como o perfil do aprendiz de letras foi esboçado a partir de um modo de dizer que o dissociava de uma base considerada "padrão". Aqui, as construções destacadas criam uma representação do curso de 
licenciatura, cujo traço característico é a congregação de alunos com interesses comuns. Contudo, há um desconhecimento sobre os resultados "efetivos" da formação, tornando-a, desse modo, indeterminada, incerta. Daí o efeito de dissociação, pelo fato de a formação apresentar-se "dissolvida" entre as contingências da vida profissional que determinará, em última análise, a "real" necessidade da sua realização. Ou seja, há um efeito de construção do professor que terá sua formação "concretizada" ao deparar-se com as necessidades contextuais, pessoais, sociais, econômicas etc. Voltemo-nos aos fragmentos:

Excerto $40 \quad \mathrm{P} 1:[\ldots]$ do ponto de vista assim se eles estão dispostos a atuar em educação básica... se eles vão... se eles vão valorizar essa atuação né... não tenho/não é uma coisa que eu possa dizer assim no geral [...] em instituição particular de ensino superior né... é totalmente diferente... o fluxo dos alunos é muito diferente...você tem uma continuidade na instituição particular e eu acho que até uma certa homogeneidade assim... em relação a quem são os alunos... como é que eles vão passando pelo curso né... aqui não... aqui é um caleidoscópio mesmo... a sala de aula é uma... coisa de louco assim... que eu acho bom... eu gosto mais de dar aula aqui né... sem dúvida... até pelo grau de envolvimento né... agora eu espero né... eu ((citou seu nome)) ... professora um ((risos)) espero mesmo que os alunos saiam... minimamente éh::: desejosos... de experimentar... aqueles que não dão aula em educação básica que saiam minimamente desejosos de experimentar né... porque é o que eu gostaria né... que esses alunos fossem para as escolas e que nas escolas eles pudessem ajudar a gente a mudar um pouco esse quadro né...

No excerto 40, há um efeito de indeterminação quanto à inserção do aluno no universo docente com a formulação: "não é uma coisa que eu possa dizer assim no geral”. Por um lado, há o destaque para a heterogeneidade do público-alvo no curso de licenciatura, daí o efeito de associação que mencionamos. Há uma agregação de valores ao curso. No entanto, o desconhecimento do "destino" do egresso torna a questão da formação pendente, criando, desse modo, um efeito de neutralização da licenciatura. Partindo da materialidade lingüística, com a formulação: "eu gostaria né... que esses alunos fossem para as escolas", concluímos que a licenciatura passa a figurar de modo distorcido, difuso, pois, havendo o preparo docente, o ingresso do aluno no mundo escolar não seria uma decorrência óbvia? Dessa maneira, há um efeito de sentido de dissociação do curso de formação de professores. O curso de licenciatura parece assumir um caráter suplementar, provisional, mantido à disposição para um uso futuro contingente. Chamamos a atenção para a imagem de incerteza provocada pela incidência de orações com verbos no subjuntivo, tais como: "que saiam minimamente desejosos de experimentar", "que esses alunos fossem para as escolas", "e que nas escolas eles pudessem ajudar a gente a mudar um pouco esse quadro". Tais construções sintáticas parecem 
provocar na voz do sujeito um efeito de submissão a um desejo individual, causando, portanto, um traço de incerteza sobre os resultados do seu trabalho. Quanto a esse aspecto, vejamos o segmento abaixo:

Excerto $41 \quad$ P1: [...] mas... por exemplo... ontem recebi um e-mail de uma ex-aluna minha de dois anos me contando que estava dando aula em uma escola... e que agora sim então ela começava a entender muitas coisas que a gente tinha discutido... muitas das coisas que a gente tinha falado... e me perguntando se ela podia voltar para conversar... eu tenho vários alunos assim que voltam né... depois que vão dar aula em algum lugar...

No excerto 41, parece haver eco das formulações trazidas no excerto 34 (seção anterior) sobre o amadurecimento para a discussão de questões educacionais. Aqui (excerto 41), o curso de licenciatura passa a surtir efeitos para o egresso após iniciar seu trabalho docente, de modo efetivo. A locução adverbial "agora sim" sinaliza uma existência "real" de um momento de "compreensão" do conteúdo do curso de licenciatura. Há, também, na enunciação um efeito de dissolução das vozes do aluno e do professor-formador; no entanto, o dizer expresso por meio de um relato indireto, sobreposto à voz do aluno, torna-o inexpressivo, fazendo com que a voz do professor-formador pareça destacada, ancorada em um argumento "verdadeiro". Em outras palavras, parece haver, no discurso, um efeito de anuência (do professor-formador) de que o curso de formação docente somente produz significados para o aluno quando ele está efetivamente lecionando. A partir do segmento exposto, temos, também, um efeito de divisão do egresso em dois grupos: alunos em efetivo exercício da docência e outros cujo destino é desconhecido. Aqueles que voltam (e já estão lecionando) parecem constituir o grupo de alunos que "compreenderam" o "sentido" da formação.

Esse quadro leva-nos a perceber a fragilidade e a inconsistência da noção de formação de professores. Diante disso, considerando a precariedade e a indefinibilidade, primeiramente, dos sentidos sobre a formação de professores, das ações pedagógicas, das condições "reais" dos alunos para se iniciar um processo de formação docente, cabe-nos indagar se o conceito de formação é legítimo. Acrescentando a tais considerações o efeito de que a compreensão da formação está vinculada às contingências das relações pessoais, profissionais, sociais etc., acreditamos que o conceito de formação de professores pode tornar-se esvaziado, desgastado, anacrônico. Conforme vimos argumentando, o discurso político-educacional (Diretrizes Curriculares) e o didático-pedagógico (professores-formadores e alunos das instituições 
pesquisadas) trazem palavras e expressões, tais como: domínio, consciência crítica, sensibilização, cuja plausibilidade vimos questionando. Em virtude da impossibilidade de determinar a abrangência dos seus sentidos, bem como sua exeqüibilidade, parece-nos paradoxal pautar a noção de formação sobre conceitos que, de um paradigma pós-moderno, tornam-se esvaziados de sentidos. Ou seja, se a noção de formação de professores está baseada em conceitos ilusórios, acreditamos que o conceito de formação docente é falacioso. Passemos a outro excerto, envolvendo a representação dos professores-formadores sobre o curso:

Excerto 42 P3: [...] eu tenho um carinho especial pela licenciatura... talvez porque eu não tenha::: éh::: também fiz licenciatura... sou formada em pedagogia... e eu tenho um pouco de empatia com os problemas né... porque eu vivi alguns problemas... e também porque a licenciatura reúne aqueles que serão de fato os professores da rede né... aqueles que vão dar aula mesmo né da quinta a oitava e ensino médio e tal... então eu tenho assim um carinho especial... eu sei que muitos que vêm para a licenciatura não vão dar aula na escola pública... até alguns começam e abandonam... mas é um... público... muito interessante...

Vemos, novamente, no fragmento acima (excerto 42), o efeito de um movimento de associação e dissociação com relação ao público-alvo e aos seus interesses profissionais. Ocorre uma agregação de valores ao curso por meio da identificação do sujeito ("tenho empatia"), pela descrição do público (são “interessantes”), e, sobretudo pela possibilidade de congregar os futuros professores da rede. Por outro lado, há, da mesma forma, um movimento de dissociação com relação às efetivas conseqüências do curso na vida dos alunos. Com a formulação "eu sei que muitos que vêm para a licenciatura não vão dar aula na escola pública”, há um efeito de desalento de P3 ao expressar a ausência de comprometimento com esse segmento educacional. Além disso, notemos também o efeito de verdade provocado pelo verbo "saber" que denota autoridade e comprometimento ${ }^{129}$ no dizer, considerando o fato de o enunciador ser professor-formador da instituição pesquisada. Ou seja, esta condição está posta: os alunos da Instituição 2, futuros professores, não vão para a escola pública. Notemos, principalmente, o efeito de fragilidade dos propósitos educacionais ao serem vinculados ao acaso ("alguns começam e abandonam”). Salientamos, novamente, o efeito dissociativo no discurso que vimos apontando. A escola pública parece figurar como meta da formação docente, na instituição pesquisada. No entanto, ela não parece ser o destino principal dos

${ }^{129}$ Cf. Weinrich, 1974. 
alunos após a conclusão do curso de licenciatura. $\mathrm{O}$ excerto abaixo parece suscitar algumas razões:

Excerto 43 P4: [...] mas há uma diversidade brutal mesmo né... em termos de formação e::: e também expectativas para a educação... alguns já lecionam... outros tiveram alguma experiência... ainda muito::: pequena na área... da prática... escolar né... alguns não querem ser professor... então... eu acho que isso:.: é uma coisa... que me incomoda e acho que é uma coisa muito contemporânea... estão na licenciatura um pouco por prevenção... se não conseguir emprego... uma coisa assim meio... complicada né... uma relação que (acho que) tem mais a ver com falta de perspectiva profissional do que vontade mesmo de ser professor né... e outros querem mesmo ser professor e estão dispostos a::: ter uma formação mais adequada...

A enunciação acima (excerto 43) nos remete ao efeito obtido a partir das formulações apontadas no excerto 40 com relação ao aspecto provisional do curso de licenciatura. A questão da "prevenção" sugerida acima parece enfraquecer a profissionalidade ${ }^{130}$ do professor, pois está implícito aí que seu trabalho, para alguns alunos, não é encarado como uma profissão. Embora esses alunos não sejam apenas aqueles provenientes do curso de letras, conforme já esclarecemos, é necessário supor que bacharelandos em língua inglesa estão aí contemplados. Quanto à questão da "profissionalidade", retomamos considerações de Monte Mór (2006, p. 351) sobre o ingresso na profissão do professor de inglês. Nas suas palavras, lecionar inglês, para alguns profissionais, "pode representar uma oportunidade em face de uma falta de oportunidade”. Isto é, diante das incertezas do mercado de trabalho, dar aulas de inglês pode representar uma garantia, uma segurança, um ancoradouro para as adversidades ou contingências da vida profissional. Desse modo, a formação de professores passa a figurar como um estratagema, uma preparação possível para uma necessidade possível e contingente. Como decorrência, o efeito de sentido veiculado pelo segmento é de uma desvalorização da carreira docente, pois sua preparação figura como ato secundário, complementar, adicional.

De fato, Bauman (2001, p. 159) nos alerta que na modernidade líquida existe a noção de atos de trabalho, como "estratégias de um jogador que se põe modestos objetivos de curto prazo". Ou seja, obtém-se um efeito da carreira docente como um trabalho de "passagem" até que outro mais "promissor" seja apresentado ao profissional docente. Mas, voltemo-nos para

\footnotetext{
${ }^{130}$ Retomando estudo de Estrela (2002), apresentado no capítulo Formação de professores, lembramos que, para a autora, a "nova profissionalidade" docente requer valores de cooperação, capacidade de iniciativa, questionamento crítico, abertura à mudança e responsabilidade ética.
} 
um último excerto sobre o tema das escolhas profissionais, no qual há o mesmo efeito de movimento associativo/dissociativo no discurso da formação:

Excerto 44 P5: [...] eu vejo uma grande contr/oportunidade para::.: a minha formação como docente... né... diante do desafio de contribuir... na formação desses que eventualmente se tornarão profissionais docentes de educação básica... não são todos que trabalharão... não consegui ainda ter idéia de qual é a porcentagem... qual é a proporção dos que se tornam... mesmo docentes...

No excerto 44 acima, destaca-se a importância do curso de licenciatura por representar uma oportunidade de auto-aperfeiçoamento. Com isso, tem-se um efeito associativo à carreira, pois "formar" pode representar um processo de "aprender". Cremos que temos aí efeitos que remetem ao conceito de formação continuada e de lifelong learner, ou seja, o profissional em constante e interminável busca do seu aprimoramento. No entanto, surge também, na cadeia discursiva, o mesmo efeito de dissociação mencionado em outros fragmentos. Primeiramente, o advérbio "eventualmente" sugere a indefinibilidade sobre a inserção profissional do egresso do curso de licenciatura. Outro efeito dissociativo é obtido, ainda, por meio da impossibilidade de precisar a quantidade daqueles que, efetivamente, tornam-se professores. Ou seja, a enunciação trazida no excerto 44 parece somar-se aos segmentos anteriores (excertos 41, 42 e 43), reforçando o efeito de condicionalidade, tornando, portanto, a noção de formação atrelada a fatores contingentes.

Vimos, nessa seção, que o principal aspecto valorativo do curso (congregação de alunos que atuarão na escola básica) torna-se enfraquecido diante da dificuldade de precisar o "real" destino dos egressos. Ou seja, a noção de "interesse comum" torna-se esvaziada do valor "prático", pois a avaliação sobre os resultados do curso permanece no âmbito da premonição. Cabe retomar aqui a noção de "ecologia da ação", proposta por Morin (2006, p. 86). O autor elabora esse conceito para referir-se aos desvios de toda ação proposta, ao deixar o âmbito daquele que a iniciou, isto é, ao entrar em contato com o espaço "exterior". Isto significa dizer que o desconhecimento, a incerteza sobre as conseqüências de qualquer ação são suas características constitutivas. Assim sendo, o desconhecimento do destino do egresso do curso de formação não poderia surtir um efeito de enfraquecimento no discurso da formação. Parece que temos aí um desejo camuflado pelo controle (pastoral care) ${ }^{131}$ pelo conhecimento (impossível), pelo cuidado acerca do futuro profissional dos egressos. Noção

${ }^{131}$ Cf. Popkewitz, 1998. 
que nos parece estar calcada no "ideário positivista", conforme explorado por Mascia (2002). Ou seja, há uma expectativa no discurso dos professores-formadores de que o curso de licenciatura possa levar a educação básica a um estado de melhoria. Em outras palavras, há um efeito de estabelecimento de uma seqüência a ser cumprida, na qual o conhecimento do curso pode ajudar a contribuir para o "progresso" da educação básica.

\subsection{A seleção e o residual}

Outro aspecto suscitado no discurso da formação trata do modo como os alunos expressam suas escolhas em relação aos docentes do curso de licenciatura, movimento que nos coloca frente a algumas representações sobre o curso e seus professores-formadores. Nesta seção, nossa discussão volta-se, então, para a maneira como um movimento associativo/dissociativo opera no discurso por meio da seleção de professores-formadores e da divisão de saberes (teoria/prática, espaço acadêmico/espaço não acadêmico). Comecemos por esse último, observando o fragmento a seguir:

Excerto 45 A3: eu acho que quando eu comecei o curso... de licenciatura... a primeira matéria... eu não fui com muita::: convicção assim... nem muita empolgação... mas... porque eu já dou aula tal... então (eu falei) não sei se esse curso vai ser útil mesmo ou não... se tem alguma coisa interessante e tal... e depois que eu comecei a fazer nas duas primeiras aulas eu já gostei muito mais do que eu achei que eu fosse gostar... eu tinha um pouco de preconceito até... (porque) é muita teorização e pouca prática...

A3, que é docente em uma escola de idiomas, atribui ao curso de licenciatura um efeito de chancela sobre sua carreira profissional, pois, excluindo-se (dissociação) do públicoalvo do curso ("eu já dou aula"), sua "formação" mostra-se completa. Resta-lhe, então, o reconhecimento profissional por meio da certificação. Com isso, o curso de licenciatura emerge do discurso como um bônus, o que para nós, causa um efeito de debilidade ao curso. Entendemos a impossibilidade de haver homogeneização de interesses, necessidades, saberes, portanto, não é essa nossa preocupação. Nossa crítica reside na constatação de que o discurso da formação docente parece se delinear de modo a fragilizar a própria noção de formação e, por conseguinte, de professor, pois deparamo-nos com dizeres que propiciam um apagamento ou esvaziamento dessas noções. 
Outro aspecto que emerge do segmento acima (excerto 45) trata da visão preconcebida sobre o curso de licenciatura. Podemos capturar, no excerto ora em análise, o efeito de autoridade veiculado pelo enunciado "é muita teorização e pouca prática", pois como A3 está lecionando ("porque eu já dou aula tal") sua fala assume um estatuto de verdade. Considerando, ainda, o tempo do verbo "ser", nota-se que, apesar da aparente mudança de perspectiva do sujeito, persiste a divisão entre prática e teoria. Isto é, a prática está em outro espaço (na sala de aula, por exemplo) e no curso de licenciatura, portanto, não há espaço para ela, cabendo somente a teorização. Como, de acordo com o segmento, a teorização só se completa com a prática, e isso o sujeito já possui, nada parece lhe faltar. Daí a noção da licenciatura como um bônus, um título ou uma "nova" experiência. Conforme já expusemos, tomamos o enunciado como um dizer que se repete. Assim, notemos como há na seqüência dos sintagmas nominais "é muita teorização" e "pouca prática" esse efeito de dizer cristalizado pela repetição. Tais enunciados emergem do discurso com uma aparente naturalização, por estarem acompanhados do vocábulo "preconceito", que sugere a noção de fixação de uma representação: “o curso de licenciatura privilegia a teoria". A idéia de preconceito parece privar o enunciador de agir sobre os enunciados e desnaturalizá-los, fazendo com que pareça submetido a tais dizeres.

Para A5 (excerto 46), docente e coordenador em uma escola de idiomas há mais de vinte anos, a diversidade do público no curso de licenciatura é um fator de enriquecimento para sua vida profissional (efeito associativo). No entanto, há uma sugestão de que foram poucos os cursos que acrescentaram "algum ponto de vista diferente" para a carreira profissional. Vejamos o excerto abaixo:

Excerto 46 A5: [...] teve alguns cursos que eu realmente gostei... que eu achei que adicionaram... algo né... para::: ... não só para o lance da educação mas para a minha vida mesmo... assim... da gente abrir uma janela... criar um novo ponto de vista... ou modificou algum ponto de vista existente... e::: mas foram poucos... ahn... muitos cursos... eu... sei lá... eu achei que o que estava sendo falado... não estava adicionando muito... eram coisas que::: de repente era muita teoria... que na hora do vamos ver... na hora de entrar numa sala de aula e aplicar isso... não ia na verdade levar a lugar nenhum... quer dizer... uma coisa muito bonita entendeu? ... um ideal muito legal... mas na prática não funciona muito porque não parte só do professor entendeu? ... tem toda uma estrutura em volta... da sala de aula... do aluno... da situação...

Conforme pudemos notar, a questão da divisão teoria/prática retorna no segmento acima. Há um efeito de estabelecimento do espaço "sala de aula" como local da prática - 
visão que nos parece distorcida, pois o próprio conceito de "aplicação" ("na hora de entrar numa sala de aula e aplicar isso") envolve uma teorização. Chama-nos a atenção, ainda, a inclusão de outros fatores (a estrutura em volta, a sala de aula, o aluno, a situação) como elementos importantes para a "aplicação da teoria". Notemos, do mesmo modo, como na consideração de tais fatores há uma mobilização de conceitos teóricos para se referir à "prática". Como definir a "estrutura em volta", por exemplo? O que está implicado em tal conceito? Ou ainda, como tais elementos interferem no ensino? Ou seja, é necessária uma “teoria" para explicar como tais noções são elaboradas da forma que se apresentam. É curioso notar, ainda, que apesar da experiência declarada de A5 como professor, a expectativa com relação ao curso de licenciatura parece ser pela busca de modelos. Vejamos como isso se dá:

Excerto 47 A5: [...] eu creio que seria um pouco mais útil... principalmente para pessoas que não tem experiência... não é meu caso né... se... se os professores procurassem dar... ministrar as aulas aqui não tão... academicamente mas mais praticamente entendeu? ... de um modo mais prático... que sirva de exemplo... sei lá... no futuro... o cara que está dando aula ele sempre vai lembrar de algum professor antigo né... (o cara)... eu gostava do jeito que aquele professor fazia... ou aquela professora fazia... procurar imitar isso né... aquilo funcionou... talvez funcione...

Há, novamente, nesse excerto, um movimento discursivo que torna o sujeito dissociado do público-alvo, em virtude da sua experiência. Notemos o efeito de isenção da exigência de se "ter aulas mais práticas" obtido com a formulação: "não é o meu caso". No entanto, obtém-se um efeito de necessidade camuflada, isto é, depreende-se uma busca implícita por modelos, pois embora o sujeito se mostre discursivamente dissociado do público-alvo (já tem experiência), ele está implicado no grupo de alunos. Reparemos como a sugestão para se ministrar aulas menos "academicamente", opondo-se à "mais praticamente" delineia-se como um modelo de aula. Apesar da experiência sugerida, então, parece haver ainda uma busca por um determinado tipo de aula. Com tal sugestão, a teoria torna-se vinculada ao espaço acadêmico, havendo, portanto, sua territorialização, pois no espaço acadêmico as aulas parecem ser sempre teóricas. Cabe reiterar como tais enunciados que parecem instaurar/reforçar a dicotomia teoria/prática acabam por sugerir a falsidade dessa divisão, pois, de modo involuntário, ao criticar o excesso de teoria, o sujeito também se mostra constituído por modos teorizadores de dizer. O que significa dar aula "não tão academicamente" ou "mais praticamente"? Por isso, parece-nos possível apontarmos aqui para um momento de captura da "traição" do discurso da dicotomia teoria/prática, o que vem ao encontro da tese de Coracini e Bertoldo (2003c) sobre a falácia dessa divisão. 
A noção de professor como modelo emerge também do fragmento abaixo. Reparemos os efeitos de sentido suscitados pela polifonia enunciativa:

Excerto 48 A3: [...] no meu curso de licenciatura... na matéria de introdução... a própria professora falava assim... "ah não me tomem como padrão" ... porque ela não é professora de didática... de nada disso né... metodologia... então (ela falava) "eu estou aqui para falar de ((citou sua disciplina))... então não me tomem como padrão" [...] quando a gente pensa em educação... a gente... inocentemente talvez imagina que todos os professores que dão aula no curso de licenciatura são professores maravilhosos... que dão uma aula maravilhosa... e que tem uma didática maravilhosa... a gente tem uma:.: uma expectativa... eu acho... mas eu sou realista o suficiente para saber que não vai ser bem assim... [...] mas a expectativa de alguém que está te ensinando a ensinar... acho que a nossa expectativa é que a pessoa... no mínimo... ofereça algo muito interessante e muito bom... não só na teoria mas na prática também...

Nesse excerto, nota-se a recorrência da questão do papel do professor-formador como alguém que "ensina a ensinar", devendo, portanto, ser um "bom professor". Essas concepções já foram analisadas em momentos anteriores. No entanto, um elemento de destaque diz respeito à noção de professor modelar perpassando os dizeres dos próprios professoresformadores. Há um movimento de transferência do "encargo" de ser modelo para professores de disciplinas como didática e metodologia. Com isso, a questão que merece ser levantada é sobre a legitimidade de se alimentar a concepção de modelo de professor no interior de um curso de licenciatura. Ou seja, parece haver a necessidade de postular a existência de um modelo que está por vir. ${ }^{132}$ Diante disso, não há motivo para surpresa quando nos deparamos com os dizeres que sugerem uma expectativa de encontrar professores no curso de licenciatura capazes de fornecer "algo muito interessante e muito bom... não só na teoria mas na prática". Dessa forma, há uma representação sobre o curso de licenciatura como um fornecedor de regras e fazeres adequados e possíveis de serem "utilizados na prática". Isso cria uma concepção redutora da licenciatura e dos seus professores. Considerando o movimento de dissociação dos sujeitos até aqui analisados (já têm experiência de ensino), o curso de licenciatura passa, desse modo, a figurar como um fornecedor de "novos modos de ensinar". Anula-se assim a importância da agência individual como geradora de possibilidades dentro da sua própria sala de aula, pois há necessidade de se buscar uma "fonte" de produção de conhecimentos do lado de fora dela, ou seja, na universidade.

\footnotetext{
${ }^{132}$ Estamos levando em consideração as condições de produção da formulação do professor-formador, trazido por A3, pois, segundo o aluno, tratava-se de uma disciplina introdutória do curso de licenciatura.
} 
Parece surgir daí uma representação do papel do professor como "seguidor de regras" ou "leitor de livros-guias", conforme sublinha Kincheloe (1997, p. 20), atributos que sugerem uma visão educacional norteada por princípios veiculados pela modernidade. Ou seja, há, no imaginário discursivo desses sujeitos, um modelo de professor ideal cuja postura deve ser, se não seguida, ao menos observada. No Capítulo 2 (Formação de professores), ao olharmos para análise de Ferro (1998), na qual a autora constatou a preponderância do modelo do Ofício $^{133}$ de formação profissional, propusemo-nos a observar se, apesar do intervalo de dez anos decorridos entre sua pesquisa e a nossa, poderíamos encontrar evidências que apontassem para a ênfase de tal modelo na formação docente. Julgando pela análise empreendida ao longo do trabalho e, notadamente, nesta seção, a representação do mestre exemplar, capaz de instruir o aluno por meio da demonstração de "como fazer" parece estar contemplada no discurso.

Voltemos-nos agora para a questão da escolha dos professores-formadores. A2, também docente em uma escola de idiomas, sugere ter percorrido uma "trajetória diferenciada". Vejamos suas formulações:

Excerto 49 A2: [...] quando eu comecei a fazer eu já não tinha nenhum compromisso... nenhum vínculo com a graduação aqui da letras... então eu pude me dedicar integralmente à licenciatura... e como eu tinha essa preocupação em... fazer uma BOA ... licenciatura... eu nem tinha tanta preocupação em fazer uma boa graduação... mas depois que eu estava livre das disciplinas aqui ((faculdade de letras)) ... eu... tive... como meta fazer uma boa licenciatura... eu tinha/por exemplo eu fui atrás dos melhores professores de cada disciplina... informações que a gente pega com os colegas... "olha ((exclamou))... esse sim... aquele não..." então eu realmente assim... eu dei uma... eu selecionei... se a gente pode dizer assim... os professores de acordo com informações de colegas e de pessoas que já tinham feito as disciplinas...

Da enunciação acima, emerge a importância do papel do professor como único responsável pela qualidade do curso de licenciatura. Depreendemos, com isso, um efeito dissociativo por parte do sujeito com relação ao seu próprio conhecimento e de outros possíveis agentes (colegas, outros recursos didáticos), pois parece anular-se como possível fonte de produção de saber, uma vez que deposita somente no professor do curso a responsabilidade pela formação. Parece emergir também um efeito associativo (satisfação), muito mais pautado pela possibilidade de seleção, do que pelo próprio "produto" selecionado (o professor-formador). Dessa forma, considerando a contextualização trazida por A2 (já

${ }^{133}$ Cf. Wallace, 1991. 
havia concluído o curso de letras), "fazer uma boa licenciatura" tem estreita relação com a possibilidade de escolha, independentemente, dos resultados obtidos. A valorização do papel do professor sugere, novamente, a noção de mestre como modelo. Sua influência, portanto, para a representação da noção de formação torna-se acentuada, uma vez que a expectativa de se cursar uma "boa licenciatura" está vinculada ao que possa advir dessa figura modelar. A formulação a respeito da "consulta aos colegas" para a seleção dos professores-formadores sugere existir uma representação socializada acerca do curso de licenciatura.

No próximo segmento (excerto 50), volta à baila a questão da seleção de docentes do curso de licenciatura. A6, sem experiência de ensino, sugere que ter estudado com alunos "mais experientes" foi positivo no sentido de proporcionar reflexões sobre procedimentos didático-pedagógicos. Na linha que vimos seguindo, tal dizer agrega valores ao curso (associação). Vejamos um pouco mais:

Excerto 50 A6: então... olha eu sou meio chata com umas coisas... então eu via muito... as pessoas falarem mal do curso de licenciatura... assim é uma prática comum né... então o que que eu fiz? ... as matérias que eu cursei... todas elas sem restrição eu perguntava para as pessoas antes... "ah tal matéria você fez com quem? ... como é que é o professor? ... ah ele é legal? ... ele dá mesmo? ... ele enrola?" né... então todas as matérias que eu fiz... eu fiz com excelentes professores... e eu aproveitei muito...

Com o excerto acima, vemos surgir no discurso uma noção de descartabilidade nas relações humanas. Bauman (2003/2004) posiciona-se com relação à fragilidade dos relacionamentos na pós-modernidade. Sua análise sobre os modos como as mercadorias são consumidas e descartadas com a mesma rapidez, assim que a satisfação imediata é atingida, nos leva a ver na questão da seleção dos professores do curso de licenciatura um movimento semelhante. Ou seja, há, primeiramente, a seleção dos "melhores professores" escolhidos como produtos para consumo, por outro lado, aqueles não selecionados tornam-se resíduos indesejáveis, elementos descartados do processo seletivo. Essa lógica de mercado (uso e descarte) no contexto educacional pode fazer com que a busca pelo "modelo ideal" de professor se perpetue, criando, além disso, a exclusão das capacidades individuais dos alunos para produzir sentidos à formação, ao papel do professor e à educação, de um modo geral.

Para Bauman (2001, p. 102-103), a escolha do consumidor na sociedade atual, "é um valor em si mesma; a ação de escolher é mais importante que a coisa escolhida". Percebemos 
no discurso dos alunos reflexos dessa facilidade para escolher e descartar, características tão presentes na sociedade de consumo. Não é raro encontrar exemplos de alunos que iniciam um curso e, após algumas aulas, preferem trocar de professor, por exemplo. Não nos cabe julgar as mais variadas razões, mas a lógica da busca pela satisfação imediata parece ter seu sentido estendido para a sala de aula e, conseqüentemente, para o professor. Ou seja, a demanda é por aulas "prazerosas", a concepção de professor assume proporção de entertainer, o conteúdo deve ser facilmente "digerido" e aplicado "na prática". Constrói-se com isso uma representação de aluno como colecionador de experiências, ou consumidor de "novos" fazeres educacionais.

Para encerrar esta seção, retomamos uma formulação apresentada no início do capítulo (seção 6.1 - excerto 35) por corroborar nossa análise: "eu acho que eu dei muita sorte... eu tive... excelentes professores na licenciatura". Diferentemente do processo de seleção sugerido nos excertos 49 e 50, a formulação que ora resgatamos imprime ao curso de licenciatura um efeito lotérico. Com isso, tomando os trechos analisados (excertos 35, 49 e 50), somos levados a entender que há dois modos de iniciar o curso de formação: o primeiro é baseado na seleção prévia de professores, o segundo, cabe ao acaso decidir. Ou seja, descartando a opção de seleção, e, se o aluno não tiver "sorte", seu curso de licenciatura pode ser uma experiência mal sucedida.

O efeito de depreciação do curso de licenciatura que vimos detectando no discurso é foco de interesse de estudos acadêmicos. Houssaye (2002/2004), de um ponto de vista histórico-filosófico, analisa o modo como os teóricos da educação, entre eles, filósofos e cientistas da educação (psicólogos, sociólogos, historiadores etc.), buscam deslegitimar a pedagogia, negando-a como disciplina e apontando para sua falta de especificidade. É o que esse pedagogo francês chama de "negação da pedagogia". Para ele, tal mecanismo não cessa de operar, mesmo quando há uma aparente compreensão sobre os saberes veiculados pela pedagogia. O autor advoga que o modo como alguns temas são tratados, recentemente, apesar de, aparentemente, sugerir "uma melhor compreensão da pedagogia", corresponde a um "falso reconhecimento" (p. 24). É o que chama de "novos deslocamentos da negação". Por exemplo, no trato com a questão do "par teoria-prática", afirma que há uma tendência para se admitir que "a prática produz muitos saberes a serem reconhecidos" (p. 25). Embora tal "constatação" possa parecer uma valorização da pedagogia, segundo o autor, trata-se, na verdade, de um diferente modo de afirmar a superioridade do saber científico - que segue um 
método de pesquisa reconhecido. Por outro lado, o saber pedagógico, fruto de "saberes práticos", acaba ficando restrito à "ordem da arte ou da experiência cega" (p. 25), fato que, para o autor, continua a deixar a pedagogia num plano subalterno no universo acadêmico.

Acerca das representações depreciativas sobre o curso de licenciatura, o estudo de Garcia (1994) sobre a constituição e institucionalização do campo da didática no ensino superior brasileiro também nos traz contribuições. Com o objetivo de buscar a gênese da didática como um campo de conhecimento dos currículos de formação de professores em nível superior, a autora recorre às memórias de quatro entrevistadas que viveram os primeiros tempos da didática, inicialmente como alunas e, posteriormente, como professoras, em diferentes instituições ${ }^{134}$. Essas memórias remontam à origem das Faculdades de Filosofia, no final da década de 1930, divididas em quatro departamentos: filosofia, ciências, letras e pedagogia. Após três anos de curso em alguma dessas seções fundamentais, o aluno receberia o diploma de bacharel, podendo matricular-se no curso de didática, que o habilitaria para exercer o magistério. Com esse esquema, aponta a autora, criava-se uma divisão no campo da formação pedagógica do professor em nível superior, tendo por um lado, o curso de didática para os bacharéis que aspirassem à licenciatura, e, por outro, a formação de profissionais do ensino com o curso de pedagogia.

Outro fato significativo diz respeito à contratação dos professores. Segundo pesquisa de Nadai, citada por Garcia (1994, p. 52), para as disciplinas dos cursos de filosofia, ciências e letras da Universidade de São Paulo, por exemplo, professores estrangeiros foram convidados, como resultado das "missões culturais" que o governador paulista Armando de Salles Oliveira envia à Europa, a partir de 1934, na tentativa de imprimir um caráter verdadeiramente científico à instituição. No entanto, para a área pedagógica, os professores contratados eram oriundos da Escola Normal da Praça da República ou de Escolas Normais do interior. Como esses professores estavam mais envolvidos com uma formação para a escola primária, eles enfrentavam dificuldades para ministrar o curso de didática para os demais cursos da Faculdade de Filosofia, afirma Garcia (1994, p. 53).

Apesar da respeitabilidade conquistada pela didática a partir dos anos 1960 (GARCIA, 1994, p. 121) e da ampliação do seu status acadêmico com os primeiros cursos de pós-

134 Faculdade de Filosofia, Ciências e Letras da Universidade de São Paulo, Faculdade de Filosofia da Universidade do Rio Grande do Sul e da Faculdade de Filosofia da Universidade de Minas Gerais. 
graduação, a partir dos anos 1970 (p. 147), pensamos que o modo como a didática se constituiu no meio universitário tornou sua natureza ontológica e epistemológica estigmatizada. Algumas representações depreciativas sobre o curso de licenciatura e sobre seus professores com as quais nos deparamos, no discurso aqui analisado, podem ser, portanto, reflexos de um percurso histórico marcado por dificuldades que a didática precisou superar no universo acadêmico, tais como: o estabelecimento do seu objeto de estudo e a qualificação dos seus docentes.

\subsection{A fragmentação institucional}

Esta seção tem como objetivo investigar a maneira como algumas materializações discursivas ajudam a criar um efeito dissociativo no âmbito institucional. Como vimos, o curso de licenciatura é apontado como um lócus para onde convergem alunos com interesses, formações e saberes diversos, sendo, por isso, por vezes, sugerido que, para o professorformador, tal característica representa um enriquecimento profissional. Nos fragmentos abaixo (excertos 51, 52, 53 e 54), vemos formulações que sugerem uma separação entre alguns agentes educacionais. Para melhor explicar-nos, passemos a eles:

Excerto 51 P3: [...] eu guardo uma interface assim trabalhando com educação... sociologia da educação... história da educação... sociologia do trabalho... uma área bem complicada né... eu tenho que superar um pouco... essa fragmentação institucional que existe... quem trabalha com sociologia para cá... assume um trabalho... quem trabalha com a sociologia da educação pega a sociologia da escola... só escolar né... e::: história é considerada um campo também separado... você tem que superar o bloqueio institucional... [...] aqui (( na instituição dois)) a introdução... por exemplo... à educação... eu vou fazer isso porque é denúncia... eu entrei agora na comissão de graduação e vou brigar... porque eles colocaram lá que introdução à educação é um curso... que abre né... as disciplinas... então põe assim... visão sociológica... visão histórica... visão filosófica... quer dizer... o professor/se eu sou professor na área de filosofia eu dou visão filosófica não importa o aluno... você já não tem/já é fragmentado... ainda você põe uma introdução que... que visa saber qual o professor não... então... não tem que ter essa visão... você tem que dar um curso de educação que contemple... aqueles conteúdos necessários para quem está começando a discutir educação...

A compartimentalização educacional trazida no excerto acima parece constituir-se em um trabalho desafiador para o professor-formador. A enunciação sugere um modo de operação do curso de formação. Primeiramente, com os vocábulos "fragmentação" e "bloqueio" tem-se um efeito de que a divisão interna é endêmica. Em seguida, a divisão da 
disciplina introdutória por áreas (sociologia, história e filosofia) sugere a existência de um mecanismo de criação que parece reforçar o efeito de dissociação existente no interior do curso de formação docente. A divisão proposta sinaliza a criação ou perpetuação de um movimento sistêmico no interior do curso. Supomos haver, com tal subdivisão, uma tentativa de transformação do funcionamento do curso de licenciatura para atender exigências sociais, históricas, culturais etc. No entanto, estando as características da pós-modernidade permeando a sociedade, a educação e os discursos aí produzidos, identificamos, nesse movimento sistêmico, uma visão que sugere um conflito de paradigmas. Por um lado, a noção de que a subdivisão pode levar a uma integralização; a especificidade de cada disciplina, considerada separadamente, ajudaria a compor a totalização da formação, como conceito e como realização concreta. Por outro lado, a aparente recusa do enunciador à proposta da divisão sugere a existência de uma dúvida com relação à definição de tendências pedagógicas, fato que nos parece representativo em um contexto, no qual as incertezas são mais evidenciadas do que as certezas. A partir desse momento capturado, podemos inferir que a estrutura institucional do curso, já endemicamente fragmentada, conforme sugere o discurso, considerando as noções de transitoriedade, precariedade, fluidez da pós-modernidade, pode ter seu funcionamento dissociativo exacerbado. Sob nossa ótica, tal divisão pode agregar à noção de formação um efeito ainda maior de adiamento.

Há outro efeito de sentido obtido a partir do segmento acima (excerto 51). As formulações: "eu tenho que superar um pouco... essa fragmentação institucional", "você tem que superar o bloqueio institucional" e, "eu entrei agora na comissão de graduação e vou brigar" nos provocam algumas reflexões. A repetição da expressão "ter que" traduz uma intimativa na qual o sujeito se vê envolvido. A idéia de obrigatoriedade emanada de tais expressões, encimadas pela locução verbal "vou brigar", desenha um quadro que sugere um embate individual frente a uma estrutura educacional. A irrupção do termo "denúncia" no discurso cria também um efeito "estratégico" que parece iniciar a ação do sujeito.

Conforme sublinha Bauman (2001, p. 170), “a incerteza do presente é uma poderosa força individualizadora". Tomando também suas contribuições a respeito da desregulamentação e privatização das tarefas e deveres, vemos, com as formulações surgidas no excerto 51 acima, reflexos dessa responsabilização da qual nos fala esse sociólogo. Conforme propõe, a força individualizadora torna a idéia de "interesse comum" nebulosa. Com efeito, na cadeia discursiva, o sujeito parece tomar para si a responsabilidade de 
esclarecer que a divisão da disciplina introdutória poderá fragmentar ainda mais o curso. Encontramos proximidade das reflexões do autor de Modernidade líquida em Debord (1992/1997, p. 173), em seus Comentários sobre a sociedade do espetáculo, ao advogar que "o centro diretor tornou-se oculto: já não se coloca aí um chefe conhecido, nem uma ideologia clara”. A partir do excerto 51, temos um modo de dizer que sugere uma agência individual, situacional, desvinculada de uma proposta clara de mudança ou de continuidade e, sobretudo, de suas implicações sobre a formação.

Entendemos que essa forma de ação individualizadora pode vincular à instituição e, por decorrência, à noção de formação, um efeito de fragilização. Somemos a essa reflexão formulações trazidas no excerto abaixo:

Excerto 52 P5: [...] há alguns ((aspectos sobre o curso)) de infelicidade né... que são... ((pausa longa)) praticamente incomunicação entre docentes aqui... a gente não arruma espaço tempo ou oportunidade para conversar sobre o nosso trabalho... nós... nos ignoramos mutuamente... muito fortemente... só:.: com alguns que::: eu tenho amizade anterior né... de fora daqui da faculdade... que eu chego a conversar... mesmo assim... de forma muito desencontrada... muito... episódica... e isso:.: me preocupa... fica muito lotérica a coisa... você não sabe bem para onde está indo... em que que a gente conjuga com os colegas... além de uma série de outras dúvidas... por exemplo essa... não sei quem é que se torna mesmo professor ou professora... que tipo de aproveitamento fazem... na::: enfim desta parte da formação...

Vimos acompanhando no discurso o surgimento de vários aspectos positivos do curso de licenciatura (associação), entre eles: a heterogeneidade do público-alvo, a proposta "aberta" de certas disciplinas e a "liberdade" docente. No entanto, a partir do recorte ora apresentado (excerto 52), deparamo-nos com formulações que denotam um efeito de dissociação. Primeiramente, o aspecto da "incomunicação" entre docentes. Mais uma vez, Bauman $(2001,2004)$ nos ajuda a entender que o relacionamento humano, a noção de parceria, de comunidade estão enfraquecidos. Conforme esse autor, os vínculos são mantidos até que finalidades específicas sejam obtidas. Tomando o vocábulo "incomunicação", o estado de parceria temporária da qual nos fala o sociólogo parece, então, se confirmar, ou seja, a parceria não existe mais, sua duração foi temporária.

A fragilidade das relações no âmbito educacional e, especialmente, no curso de formação traz à baila aspectos analisados no Capítulo 3 da Parte I, sobre as condições de produção das Diretrizes Curriculares. Apontamos, naquele momento, por meio do par 
"hopelfear" (POPKEWITZ, 2006), aspectos citados pelo membro do comitê elaborador das Diretrizes Curriculares de Letras, que poderiam tornar a leitura e a discussão dos documentos acontecimentos eventuais (fear). Entre eles, o individualismo e o comodismo por parte do professor, cujo trabalho solitário impede a integração entre os conteúdos das diversas disciplinas. Foi apontada também a questão da demanda universitária e do predomínio do interesse docente pela pós-graduação em detrimento da graduação. Desse modo, as formulações com as quais nos deparamos no excerto 52, somadas àquelas trazidas no excerto 51, parecem ser representativas dos dizeres do membro da equipe elaboradora das DCL. Entendemos que o trabalho educativo não se restringe ao espaço sala de aula, pois envolve o estabelecimento de diversas relações (com outros docentes, visitas a instituições de ensino etc.). No entanto, se tomarmos a formulação "nós... nos ignoramos mutuamente" há um quadro bastante diferente. O segmento abaixo parece corroborar tal efeito:

Excerto 53 P5: [...] o trabalho educativo deve ser também... estabelecer vínculos com outros agentes educativos... isso quer dizer... se entender... se comunicar... entender os outros... colocar perguntas... enfim... oferecer-se a colaboração... tudo isso que não é o que a gente faz... isso para nós não é educação especialmente educação escolar... isso aí é coisa que a gente não pode fazer porque está dando aula ((risos)) ... seria até legal... diriam os professores... mas... não posso... professor... eu tenho que dar aula ((risos)) ... isso não é educação... não é educação escolar... isso é extra-escolar... extraordinário... tangencial... eventual... não central...

A partir do segmento ora exposto, deparamo-nos com efeitos de sentido que contemplam os dizeres do membro do comitê elaborador das Diretrizes Curriculares de Letras a respeito do individualismo e do comodismo dos docentes universitários. Não temos materializações lingüísticas que apontem para razões, tais como a priorização da pósgraduação, entretanto, quanto à demanda interna ("eu tenho que dar aula"), entendemos surgir daí uma enunciação indeterminada ("diriam os professores"), que produz um efeito de coletivização. Emerge, então, do discurso, a noção de um professor do curso de licenciatura cujo trabalho docente está, unicamente, restrito ao espaço sala de aula. Tal representação parece-nos pouco condizente com uma visão pós-moderna de educação que busca reformular concepções e relações, valorizar a imprevisibilidade do trabalho didático-pedagógico e considerar os saberes locais. ${ }^{135}$

${ }^{135}$ Cf. Kiziltan, Bain e Cañizares, 1993; Usher e Edwards, 1994; Kincheloe, 1997. 
No excerto 53, deparamo-nos com um painel interno que se mostra dissonante, marcado pela incompreensão entre os docentes, cujos procedimentos pedagógicos parecem ser padronizados (valorização da aula). Ponderemos sobre a representação da instituição que as formulações trazidas ajudam a compor. Considerando as reflexões de pensadores, apresentadas em nosso primeiro capítulo (Pós-modernidade, educação e contingência), sobre os desafios da educação e, por conseguinte, da formação a partir de um paradigma pósmoderno, parece-nos que, pelos dizeres ora analisados, a noção de formação de professores está fragilizada. As formulações trazidas por P5 parecem não encontrar eco, ou seja, tem-se um efeito de uma "luta" solitária; existe um dizível (é preciso investir nas relações, é preciso haver interação entre os docentes, é preciso estar "aberto" a novas propostas e procedimentos) que, no entanto, não é concretizado. É um esboço de enunciado, pois ao não ser "assumido" pelo sujeito, parece permanecer flutuante, à espera de ser materializado. A partir de um funcionamento discursivo que sugere uma dissociação (institucional e corporativa), cria-se no discurso uma imagem esfacelada da formação docente.

Para concluir esta seção, trazemos um segmento, no qual a questão da fragmentação institucional é abordada, em um nível diferente dos apresentados anteriormente (excertos 51, 52 e 53). Passemos a ele:

Excerto 54 A2: [...] porque aqui na letras a gente não tem nada que direcione a gente para a área de educação... e isso eu sinto muita falta... [...] eu acho que a universidade deveria dar as mãos... para tentar fazer/dar alguma contribuição para o ensino::: fundamental e médio... para você ver... o que a gente estuda no mestrado e no doutorado não tem nada a ver com a linguagem que é utilizada no ensino escolar... no ensino formal... então há um descompasso tremendo... ninguém está interessado por exemplo em... em promover alguma coisa diferente na área do ensino... [...] eu acho que tem um descompasso muito grande entre aquilo que a gente estuda... no mestrado... no doutorado... e aquilo que a escola promove... porque não existe um diálogo... entre as partes... é o meu ponto de vista... eu não vejo nenhum ponto assim que a gente pudesse dizer... dialogamos...

O segmento acima nos faz resgatar momentos anteriores da análise (excerto 33), nos quais tivemos um efeito de indeterminação a respeito da responsabilização pelo “direcionamento pedagógico" dos alunos originários do curso de letras. Aqui (excerto 54), temos efeito semelhante. Inicialmente, há na enunciação uma sugestão de que o curso de letras poderia, também, aproximar-se das discussões educacionais. Ou seja, atribui-se ao curso de letras a responsabilidade pelo amadurecimento dos alunos acerca de questões educacionais. 
No entanto, há um deslizamento da instância departamental para a universitária ("a universidade deveria dar as mãos”), fazendo com que tal responsabilização torne-se diluída entre os departamentos (letras e educação). Em momento posterior, ainda, o substantivo pronominalizado "a gente" dilui a responsabilização da "transferência" daquilo que aí se estuda para a educação básica, pois não está claro, no fio discursivo, se a referência é feita ao corpo discente, à academia, ou à instituição universitária como um todo. Com o enunciado "ninguém está interessado [...] em promover alguma coisa diferente na área do ensino", temse um efeito de prostração generalizada (academia, departamentos, alunos, docentes etc.). Fato que nos traz de volta análise anterior sobre a iniciativa individual de "reparação". Isto é, o painel trazido, no segmento ora em análise, nos causa um efeito de abandono, de falência de interesses de propósitos educacionais. Com isso, cria-se uma situação expectante: alguém deverá fazê-lo (reparar o painel, contribuir com a educação básica, ajudar no amadurecimento "educacional" dos alunos etc.), contudo, isso permanece incerto, vago. No nosso entendimento, com esses efeitos, temos uma imagem de fragilização da instituição acadêmica, da docência e, notadamente, da formação de professores.

Há, também, um efeito de territorialização do saber. Assim como em fragmentos discursivos anteriores (excertos 45 e 46) vincula-se a teoria ao espaço acadêmico e a prática, à sala de aula, no fragmento acima (excerto 54) ocorre um movimento similar. Nesse imaginário discursivo, no qual a universidade é o espaço onde se produz conhecimento, a responsabilidade pela "solução" dos problemas da educação básica parece estar somente a cargo da instituição acadêmica. A formulação "não existe um diálogo... entre as partes... [...] eu não vejo nenhum ponto assim que a gente pudesse dizer... dialogamos" sugere essa atribuição de dever à universidade, pois a separação inicial (letras/educação) parece estar contida em uma das partes mencionadas. Ou seja, pela própria ambivalência da linguagem, notamos ocorrer aqui um deslizamento de sentidos, tornando difusa a questão da responsabilização, pois cabe também supor que as partes referidas poderiam ser: a universidade de um lado, e, de outro, a “escola”, representada pela educação básica.

Por A2 ser aluno e professor, entendemos que seu dizer situa-se, duplamente, entre fronteiras. Primeiramente, entre a fronteira do saber específico (letras) e o saber pedagógico (educação). Mas, em seguida, pelo efeito de deslizamento da linguagem, figura também entre a fronteira do "centro autorizado e provedor do saber" (universidade) e seu exterior, região marcada como espaço carente de contribuição (escola). Tal representação parece excluir a 
concepção de conhecimento como algo a ser construído e a escola como lugar de produção de conhecimento.

Sant'Anna (2007) apresenta discussão importante nesse sentido, ao investigar as representações de/sobre professores de literatura. Por um lado, o professor da educação básica é representado como um sujeito marcado pela falta (de conteúdo, eficiência, interesse etc.). No entanto, quando esse mesmo professor passa para o outro lado da fronteira (a universidade), ocupando a posição de pesquisador, sua falta não se completa. Ele passa, por sua vez, a apontar para as faltas do sujeito professor da educação básica (posição que, até então, ocupava), dando continuidade a um processo de reprodução de representações. Segundo a autora, essa falta não se completa, pois é dela "que se alimentam as representações dos discursos sobre o sujeito que está na escola" (p. 79). Isto é, mesmo estando na universidade, o pesquisador continua defasado com relação à produção acadêmica, pois a parte que o completaria torna-se ilusória, fictícia. De acordo com Geraldi (1991, p. 88), é neste sentido que "o professor emerge como categoria sob o signo da desatualização", isto é, não consegue estar atualizado com as pesquisas mais recentes em sua área e, tampouco, é produtor de conhecimento. Perante esse quadro, entendemos ser possível falar de institucionalização de uma formação constantemente prorrogada, considerando que os sujeitos são interpelados por um tipo de funcionamento discursivo circular, no qual a falta é a fonte propulsora.

\section{5 "A sociedade de segredo"}

Nesta seção, os fragmentos apresentam maior estreitamento com os alunos de letras da área de língua inglesa. Além de algumas representações sobre eles, os excertos aqui reunidos trazem visões sobre a educação básica e sobre a relação estabelecida entre a universidade e esse segmento de ensino. Segundo P1 (excerto 55), a maioria dos alunos já tem experiência de ensino, trabalhando no ensino formal ou em escolas de idiomas. Desse modo, embora a licenciatura seja um curso de formação inicial, na verdade, não há "professores" em formação inicial. Quanto ao perfil desse alunado, há uma sugestão de divisão em três grupos, sendo o primeiro composto por alunos-professores ${ }^{136}$ "mais experientes”. Esses já lecionam, há algum

\footnotetext{
136 Empregamos a expressão "aluno-professor" para fazer referência ao aluno do curso de licenciatura que também leciona.
} 
tempo, em escolas de idiomas e voltam para a licenciatura a fim de "buscar uma identidade profissional". Vejamos, primeiramente, os trechos abaixo para seguirmos com nossa análise:

Excerto $55 \quad \mathrm{P} 1:[\ldots]$ alunos que já trabalharam em muitos lugares que voltam com uma vontade de assim... "não agora eu quero me profissionalizar... eu quero brigar para ter um registro que não me diga lá que eu sou técnico de laboratório de línguas né... eu quero ser professor na minha carteira de trabalho né... ou eu quero ter essa oficialização daquilo que eu faço... eu não sou amador... eu sou profissional... então eu acho que eu tenho que ter a qualificação também reconhecida" [...] aí tem esse perfil de alunos mais maduros... que conseguem éh::: por uma opção muito clara né... gente que volta depois de muito tempo fazer licenciatura então parece que está disposto a encontrar um outro modo de trabalho né...

Há um segundo grupo formado por alunos, na faixa etária situada entre 20 e 25 anos, cujo percurso universitário parece ser a graduação no instituto específico seguido pela licenciatura. Com relação a esse público, olhemos para o trecho abaixo:

Excerto $56 \quad \mathrm{P} 1:[\ldots]$ os mais novos são mais saudosistas $[\ldots]$ os mais novos às vezes vão para a escola e acham que sabem todas as respostas... [...] e essa coisa do saudosismo é mais ou menos assim... tem dia que eu brigo até na sala né... pega um menino/menina de vinte e pouquinhos anos que fala assim... "ah mais no meu tempo não era assim" ... eu digo qual é o seu tempo filha? ... o seu tempo é agora... você ((falou rindo)) não pode falar no meu tempo não era assim... imagina que idéia que no seu tempo era diferente você tem vinte e poucos anos o seu tempo é hoje ((exclamou)) [...] mas os alunos... parece que compram mais esse discurso... os mais novos... parece que é mais difícil fazer com que eles percebam que eventualmente isso é uma... uma... é um modo de falar sobre o que que é a escola que é generalista... não é específico... [...] é mais difícil com quem é mais novo do que com quem já tem mais experiência né... é interessante isso né... éh::: e aí/então tem esse perfil assim do aluno mais novinho que é o mais nostálgico... nostálgico não sei por que né... pela idade não deveria ser né... mas parece que compra essa idéia de que é tudo ruim hoje... de que a escola é uma porcaria... de que o professor é um sofredor né... e fica muito impressionado quando ele vai fazer estágio e um professor fala para ele assim... "ah você é tão novinho pensa em outra coisa para a sua vida" né... daí quando ele escuta isso de um professor... o relatório dele quando você lê é só sobre problemas e as dificuldades ele não consegue nem... nem visualizar uma luzinha no fim do túnel... eu acho interessante isso...

Finalmente, no excerto 57, apresentamos o terceiro grupo constituído também por alunos-professores que estão atuando no ensino formal (público ou privado). Vejamos o excerto:

Excerto $57 \quad$ P1: [...] e tem um terceiro grupo que é difícil também que é dos alunos que já dão aula em escola... não em escola de língua que já dão aula em escola né... porque no geral eles dão aula em uma escola ou já deram aula em uma escola e 
aí tomam a parte pelo todo... então assim... dar aula naquela escola é como dar aula em todas as escolas... [...] também assumem um pouco essa idéia de... agora eu já sei qual é a verdade... é difícil quebrar com essas... é difícil lidar com essas situações né...

Acreditamos que o painel que acabamos de expor (excertos 55, 56 e 57) ilustra o efeito associativo provocado pela diversidade de perfis, apontado anteriormente, a partir da formulação: "aqui é um caleidoscópio mesmo... a sala de aula é uma... coisa de louco assim... que eu acho bom... eu gosto mais de dar aula aqui" (excerto 40). Entretanto, nossa observação volta-se para a possível produção de sentidos sobre o papel do professor de inglês da escola pública, a formação docente e a educação, de modo geral. Considerando a heterogeneidade dos alunos do curso de licenciatura, supomos ocorrer uma hibridização ${ }^{137}$ de perspectivas, representações, interesses profissionais, objetivos educacionais, cujos efeitos devem ser investigados. Monte Mór (2006, p. 355), por exemplo, analisa que os objetivos do ensino de idiomas na educação básica (ensino fundamental e médio) se confundem com as propostas do ensino de inglês em escolas de idiomas. Tal visão poderia ser fruto de uma adaptação (tradução) das representações acerca do objetivo do ensino de língua estrangeira na educação básica, ocorrido durante o próprio processo de formação?

De uma perspectiva bakhtiniana, entendemos que as identidades são produzidas a partir do contato com um elemento outro, tornando possível, dessa forma, incontáveis processos de identificação. No entanto, julgamos pertinente levantar algumas ponderações acerca de possíveis representações conflitantes coabitando o espaço da formação. De um lado, ao olharmos a reprodução dos dizeres dos alunos do "segundo grupo" (excerto 56): "é tudo ruim hoje", "a escola é uma porcaria" e "o professor é um sofredor", que nos parecem do domínio do repetível ${ }^{138}$, notamos um efeito de fomentação de uma visão depreciativa do ensino de inglês na educação básica e, por conseguinte, do seu professor. Essa, portanto, parece ser uma representação existente entre o grupo de alunos da licenciatura.

Juntamente com tal representação, identificamos uma outra, na qual a imagem de professor experiente está atrelada ao período trabalhado dos alunos-professores do "primeiro" e do "terceiro grupo" (excertos 55 e 57), também observada anteriormente na análise dos excertos 45, 46 e 47. Cabe ressaltar que os alunos-professores do primeiro grupo, na maioria,

\footnotetext{
${ }^{137}$ No sentido em que o termo é trabalhado por Bhabha (2007).

${ }^{138}$ Cf. Foucault, 2007.
} 
não atuam na educação básica, conforme dizeres de P1. Mediante, então, uma representação da escola básica como "local da impossibilidade" coabitando o espaço da formação com uma outra representação da docência que prioriza o fator tempo de experiência em sala de aula, julgamos haver um cenário propício para a criação de uma imagem da docência que, ao enfatizar apenas o saber docente como fruto do tempo de experiência de ensino, exclui a possibilidade de construir uma noção de conhecimento que leve em conta desafios intelectuais, emocionais e estéticos. É o que afirma Britzman (2003, p. 229), ao analisar mitos culturais $^{139}$ que parecem assolar os futuros professores. Dessa perspectiva, os professores “experientes" parecem prescindir da interação com os alunos "inexperientes" (segundo grupo, conforme divisão proposta), uma vez que o saber docente depende do seu esforço individual e da sua autonomia na sala de aula (adquiridos com o tempo). Para esse grupo, então, buscar a licenciatura, ou buscar uma profissionalização ou uma oficialização de um fazer pedagógico pode significar simplesmente uma nova rotulação ("eu quero ser professor na minha carteira de trabalho"), pois se já possui "experiência" e, para ser professor, isso basta, nada the resta buscar na licenciatura. Com isso, além da interação e do compartilhamento de experiências como fontes produtoras de saber se tornarem "descartadas", supomos ocorrer também uma desvalorização da imagem da educação básica e, principalmente, do seu professor, com a decorrente valorização do ensino "informal" 140 .

A expectativa de encontrar um "outro modo de trabalho" (excerto 55) faz emergir, novamente, a representação da universidade como fonte produtora e provedora de métodos e teorias que podem aplacar as dúvidas e dificuldades existentes "lá fora". Como isso não é possível, pode haver um efeito de frustração, pois os professores que "ensinam a ensinar" também não possuem todas as "respostas". Isso pode fazer com que o aluno "experiente" torne a valorizar sua vivência em sala de aula, depreciando a vivência do curso de licenciatura e perdendo de vista a possibilidade de construir conhecimento por meio de novos encontros pedagógicos. Algumas formulações a respeito de um modo de ensinar "prático" (apontadas nos excertos 45,46 e 47) e a busca por um "outro modo de trabalho" (formulação trazida no

139 Os três mitos apresentados pela autora são: "Tudo depende do professor" (Everything depends on the teacher), "O professor como especialista" (The teacher as expert) e "O professor se faz por si mesmo" (Teachers are self-made). No primeiro, a autora aborda a noção de que, para haver aprendizagem, o professor precisa saber exercer controle e poder sobre os alunos. O segundo mito trata da valorização do saber docente; quanto maior seu conhecimento sobre métodos e teorias, mais apto ele estará para ensinar. Quanto ao último mito, a discussão volta-se para a construção de imagens do professor como alguém que se faz por esforço próprio e possui qualidades inatas para a profissão.

140 Adotamos esse termo no sentido em que é empregado por Monte Mór (2006), para fazer referência a institutos de idiomas. 
excerto 55) podem sugerir uma tentativa de encontrar um modelo de professor, o que nos faz retomar reflexões de Britzman (2003, p. 230) sobre o mito do "self-made teacher". Tal possibilidade pode construir uma representação do ato pedagógico como uma "incorporação" (identificação forjada) de características comportamentais e atitudinais, ou "uma roupa que se prova até conseguir resultado desejado", nas palavras de Britzman (2003, p. 231, tradução nossa).

A análise de Quirino de Souza (2006) ${ }^{141}$ sobre a influência do modelo neoliberal ${ }^{142}$ na educação contribui com nossa discussão. Uma de suas conclusões aponta para a valorização do conhecimento da língua inglesa como ferramenta indispensável para se alcançar o "sucesso" no mercado de trabalho. Noção que é transmitida para os alunos, conforme aponta a pesquisadora. Além do discurso da necessidade de aprendizagem dessa língua, a autora destaca também a tentativa de busca por modelos institucionalizados e bem sucedidos de professor, ocorrendo com isso, uma valorização da necessidade de aperfeiçoamento constante do docente.

Esses ideais neoliberais parecem presentes no movimento de retorno à universidade, materializados no enunciado "encontrar um outro modo de trabalho" (excerto 55). Na nossa perspectiva, a volta à universidade como busca por uma "nova profissionalização" ou "oficialização" do trabalho não representa apenas uma nova configuração profíssional. Parece-nos também presente aí a naturalização de uma busca incessante por modelos (ideais neoliberais), uma vez que apontamos para o efeito de neutralização do curso em si (busca pela certificação). Ademais, é possível depreender a incapacidade ou a debilidade do profissional como construtor de possibilidades educacionais. Ou seja, parece existir, de forma naturalizada, um discurso da formação que preconiza a retorno ao meio acadêmico como forma de complementar o saber docente. Obviamente não estamos desconsiderando as rápidas transformações sociais, culturais, econômicas etc., que perpassam a vida em sociedade e compelem o indivíduo a estar e ser literalmente "plugado" (para usar uma metáfora pósmoderna). Mas o aspecto que merece ser questionado é o discurso da soberania acadêmica

\footnotetext{
${ }^{141}$ Nesse trabalho, a pesquisadora investigou a construção identitária do professor de inglês do ensino médio em escolas públicas da cidade de São Paulo e as influências dos ideais neoliberais sobre eles.

142 Conforme esclarece Bianchetti (2001, p. 21), o neoliberalismo surgiu durante a década de 1970, sendo definido como "um movimento político-econômico heterogêneo consolidado nos países capitalistas desenvolvidos, cuja proposta econômica significa o retorno aos princípios ortodoxos do liberalismo, ou seja, às propostas da economia clássica como única alternativa de superação da crise pela qual passam essas sociedades".
} 
prevalecendo como fonte de saber, de novos métodos, novos modelos etc., que subjaz nesse movimento de retorno.

Tal visão nos faz pensar que o discurso da formação já traz no seu bojo essa "semente do retorno". Nessa linha de pensamento, a representação da formação como instituição fragilizada desperta no profissional o desejo de busca incessante. Há, sobretudo, um efeito de veiculação, no aluno, de uma imagem de professor que nasce marcado pela heteronomia, que o torna incapaz ou inábil para promover ou gerar mudanças no seu trabalho. Nesse sentido, tem-se o efeito de uma habilitação voltada para a compreensão da transitoriedade do conhecimento, mas não para a possibilidade de agência sobre ele. Dessa forma, o profissional deve sempre regressar, pois não está suficientemente preparado para enfrentar as incertezas do seu trabalho. Nesse sentido, Pignatelli (1994) nos fornece uma interpretação provocadora ao afirmar que embora a pesquisa seja valorizada pelos professores, é raro vê-los engajados no processo de construção e administração da pesquisa. Por isso, conclui que "é mais freqüente que os professores se vejam como consumidores de pesquisa" (p. 141).

Outra imagem dissociativa no discurso é sugerida a partir da característica específica do terceiro grupo acima mencionado (professores do ensino formal - excerto 57). Esses alunos, por já serem também professores, segundo P1, acreditam possuir respostas para várias questões de ordem pedagógica, assumindo uma postura de "donos da verdade" (tomam "a parte pelo todo"). Ou seja, os alunos tomam questões específicas de uma determinada escola e transferem para todas as escolas, universalizando, portanto, características locais. Com isso, há, novamente, um efeito de neutralização da licenciatura, pois se "a verdade" está em outro local, a preparação docente parece estar desvinculada dessa outra realidade. Seu propósito torna-se, então, meramente burocrático.

Reiterando a questão da incerteza das escolhas profissionais, olhemos para o excerto seguinte:

Excerto $58 \quad \mathrm{P} 1:$ [...] então eu tenho muitos retornos assim de alunos que... que... já... que abraçaram mesmo a idéia de dar aula em educação básica né... e acho também que às vezes é uma coisa também... de interesse financeiro até né... é... notório a diferença entre pagamento de professor em escola de língua e a::: ... e a::: ... vamos dizer assim a::: a tranqüilidade né para você se organizar ao longo de um ano né... a atribuição de aulas né para quem dá aula em escola regular e para quem dá aula em escola de língua né... o sujeito que dá aula em 
escola de língua tem que... tem que jogar com muitas variações ao longo do ano né... e na escola regular... se ele consegue se envolver... aquilo que ele tem no começo do ano é aquilo que ele vai ter até o final do ano... tem esse lado também... as pessoas talvez vão amadurecendo e vão... e vão achando que isso é mais... negócio para a vida delas né... não sei...

Outra questão que parece perpassar o discurso dos alunos diz respeito à perspectiva do mercado de trabalho. Lembramos que, ao analisarmos o excerto 43, apontamos para questão semelhante a respeito da escolha da licenciatura como "prevenção", tomando reflexões de Monte Mór (2006, p. 351) sobre o ingresso na profissão do professor de inglês, representando uma "oportunidade em face de uma falta de oportunidade". Nessa perspectiva, o excerto 58 traz algumas materializações lingüísticas que apontam para uma imagem desoladora da profissão. Quando P1 enuncia “já... que abraçaram mesmo a idéia de dar aula em educação básica", a locução conjuntiva causal "já que" ajuda a criar um efeito dissociativo na "profissionalidade" do professor de inglês. Voltar-se para a educação básica passa a significar aí um retrocesso, uma escolha circunstancial. Mesmo representando uma opção menos nobre, há de se considerar o aspecto financeiro (acaba sendo mais "negócio" para a vida deles). Logicamente, não estamos ignorando as necessidades sociais, econômicas dos indivíduos, mas o fato de, no discurso, a construção da "profissionalidade" do professor de inglês estar associada a aspectos, aparentemente, imponderáveis (licenciatura com status de bônus e casualidade da escolha profissional). Sendo assim, a imagem do docente, do curso e da própria noção de formação tornam-se desprestigiadas.

Julgamos haver no segundo grupo (excerto 56), composto por alunos cuja trajetória universitária é, aparentemente, "linear" (graduação em língua inglesa, seguido da licenciatura), alguns aspectos conflitantes com relação à profissão docente. Lembramos que o grupo destaca-se por ser mais "saudosista", "nostálgico" - característica questionada pelo enunciador (P1) ao levar em conta a idade dos alunos. No entanto, do nosso ponto de vista, a nostalgia parece sugerir a falência do ideal de progresso da modernidade. É relevante considerar, por meio da polifonia enunciativa, as vozes trazidas, pelos alunos, dos professores da rede oficial de ensino, onde realizam os estágios supervisionados. Retomando os enunciados: [os alunos] “compram essa idéia de que é tudo ruim hoje... de que a escola é uma porcaria... de que o professor é um sofredor", sobretudo, com o dizer "ah você é tão novinho pensa em outra coisa para a sua vida", vemos uma representação da carreira docente e da escola básica como um local de exílio para onde convergem degredados do mercado de trabalho. 
Conforme análise de Lindblad e Popkewitz (2004b, p. xxv), a nostalgia reúne um duplo: um sentimento de perda e desarmonia (do/com o passado) e de esperança com a possibilidade de renovação (do futuro). Do nosso ponto de vista, a nostalgia dos alunos é significativa se considerarmos um contexto no qual visões da modernidade se conflitam com as concepções sociais, culturais e educacionais da pós-modernidade. Tomando dizeres de P1, então, o discurso dos alunos parece estar encharcado da desilusão "emprestada" dos professores da educação básica - reflexo da falência do ideal modernista de escola -, pautado no controle, nas certezas de conceitos e fundamentos. No entanto, tomando a formulação: [os alunos não conseguem] "nem visualizar uma luzinha no fim do túnel" (excerto 56), a esperança de renovação parece não se constituir. Nesse sentido, a nostalgia parece figurar como um sentimento forjado em virtude da inadequação com a faixa etária dos alunos. Tampouco encontramos materializações lingüísticas e discursivas no sentido de sugerir a tal esperança de renovação veiculada pelo vocábulo "nostalgia", conforme Lindblad e Popkewitz (2004b) propõem. Se considerarmos, ainda, a variedade de interesses e perspectivas de outros colegas (alunos-professores "mais experientes") que procuram na licenciatura uma nova "profissionalização", supomos que o professor-formador necessita de uma força hercúlea para fazer despertar nos alunos o interesse pela educação básica. Julgando pelo quadro que ora apresentamos (incerteza das escolhas profissionais, falta de amadurecimento educacional, esforço individual do professor-formador etc.), os resultados do despertar do interesse pelo ensino básico parecem inscrever-se num futuro casual.

O recorte abaixo parece retratar os diversos embates do professor-formador com relação ao ensino da língua inglesa na rede pública. Vejamos o excerto:

Excerto $59 \quad \mathrm{P} 1:[\ldots]$ eu acho que o mais difícil o que eu mais me empenho assim é em dizer pra eles que... mostrar pra eles né... e fazê-los acreditar que é possível a gente sair desse círculo vicioso assim de dizer... "ah o professor não consegue dar/ensinar muito bem a língua porque não tem material... porque tem muitos alunos na sala" ... sempre tem uma muleta né? ... "é porque os alunos são terríveis... é porque... tem muita gente... é porque o professor tem pouco apoio..." acho que a gente tem que encontrar caminhos de superação... nisso eu me empenho bastante pra fazer com que... pelo menos eles ponham de lado essas... essas síndromes...

Os dizeres dos alunos, trazidos no segmento acima (excerto 59), parecem evidenciar um quadro patológico da educação básica que se mantém. Vale notar o efeito do termo "síndromes" na cadeia discursiva. Cabe retomar aqui conceito de Guilhon Albuquerque 
(1980) sobre institucionalização. Ou seja, há um efeito de perpetuação do quadro sindrômico $^{143}$ acerca da educação básica que se mantém pelo reconhecimento. Podemos acrescentar que esse reconhecimento é duplo, uma vez que os alunos repetem noções enunciadas por professores da rede oficial de ensino. Ao repetirem, portanto, além de ajudarem a sedimentar uma representação, dão "ares" de reconhecimento acerca do quadro apresentado. Há, ainda, um efeito de exuberância acrescentado ao quadro acima esboçado, ao tomarmos o trecho seguinte:

Excerto 60 P1: [...] por mais que você tenha evidências de uma situação que mostre o contrário dizer que não se aprende língua estrangeira na escola é ah... máxima né... a máxima na boca dos alunos... na boca dos pais... na boca dos donos de escola... na boca dos professores né... então/eu digo isso por mais que se tenha evidência contrária... porque tem muitos... muitos professores muito bons... fazendo trabalhos muitos bons né...

Outro efeito de embate surgido no discurso parece estar centrado na tentativa de desnaturalização da "máxima" apresentada. Ou seja, há um dizer, do domínio do repetível, compartilhado entre alunos, pais, professores, donos de escolas etc., que irrompe no discurso, ocasionando um efeito de reconhecimento acerca da "disfunção" do ensino de língua estrangeira na educação básica. Conforme Guilhon Albuquerque (1980, p. 99), o reconhecimento advém "de fora". Com efeito, podemos capturar, na enunciação acima, dizeres que atestam o efeito de reconhecimento num espaço exterior à escola. Primeiramente, julgando pelos excertos ora apresentados (59 e 60), entendemos existir uma falta de clareza acerca dos propósitos do ensino de língua estrangeira na educação básica. Admitindo que os objetivos da aprendizagem de língua estrangeira não devem restringir-se à capacitação do aprendiz para usar uma língua estrangeira apenas para fins comunicativos (SECRETARIA DE EDUCAÇÃO BÁSICA, 2006, p. 92), vemos um efeito de desconhecimento generalizado (por parte dos pais, alunos, professores, donos de escola etc.) no discurso. Se tomarmos, novamente, pesquisa de Monte Mór (2006), no qual a autora discute o modo como a escola "informal" (institutos de idiomas) acaba por interferir na escola formal (educação básica) e nos cursos de formação de professores, supomos que, do ponto de vista mercadológico, a ausência de compreensão dos objetivos educacionais ligados ao ensino de língua estrangeira torna-se produtiva. Em outras palavras, a escola "informal" se beneficia também do efeito de desorientação acerca dos propósitos educacionais da aprendizagem de língua estrangeira na 143 Termo comumente empregado na medicina para designar um "grupo de sintomas e sinais que, considerados
em conjunto, caracterizam uma moléstia ou lesão" (ANDREI, 1979, p. 960). 
educação básica. A situação torna-se ainda mais agravada quando se observa a maneira pela qual o discurso da mídia acaba produzindo efeitos no campo educacional. ${ }^{144}$ Desse modo, temos, novamente, com os excertos acima (59 e 60), o mesmo efeito de luta individual, conforme vimos em segmentos anteriores (excertos 51, 52 e 53). A voz que enuncia nos excertos 59 e 60 parece sufocada diante do entrecruzamento de diversas vozes ou discursos (da mídia, dos pais, da escola "informal” etc.). Compreendemos que essa é condição inerente do diálogo, conforme teoria bakhtiniana, portanto, não pressupomos um discurso homogêneo, de vozes uníssonas. No entanto, os efeitos que vimos apontando, ao longo da análise, nos sugerem a construção de uma noção de formação como uma luta solitária - fato que, conforme já apontamos, fragiliza o funcionamento institucional, a concepção de professorformador e do futuro professor.

Concluímos a presente seção com algumas representações, envolvendo a questão do estágio supervisionado, realizado numa escola pública, como também sobre os cursos de bacharelado e licenciatura da Instituição 2, entre outras. Vejamos como o funcionamento discursivo parece indicar o estabelecimento de um tipo de relação na qual o curso de licenciatura só passa a produzir significados quando há uma transferência do conteúdo (teoria) para a sala de aula ("prática"). Além disso, vejamos também algumas representações que agregam valores à educação (efeito associativo), enquanto outras corroboram uma noção de fragilidade da profissão (dissociação). Comecemos com A5 que, conforme explicitamos, é professor e coordenador em uma escola de idiomas há mais de vinte anos:

Excerto 61 A5: [...] cada um ((aluno)) com celular na mão... um ficava tirando foto do outro assim... ficavam olhando as fotos do celular... a professora falando com a parede... né... as meninas ali lixando a unha... uma deitada no colo da outra... puxando... sabe... arrancando cílios... né... assim... então era uma sala de aula que tinha... a que eu assisti mais... tinha mais ou menos uns trinta e poucos alunos... ahn... fisicamente a sala não era muito legal... era meio detonada... as carteiras eram... algumas estavam quebradas... nem sempre eu arrumava um lugar decente para eu poder sentar...

O efeito de desolação obtido a partir do excerto acima parece ser exemplar do quadro sindrômico da educação básica, trazido no discurso dos alunos e mencionado anteriormente. A enunciação de A5 vem, então, carregada de desapreço pela educação pública, trazendo de

${ }^{144}$ A esse respeito, lembramos pesquisa de Carmagnani (2003, p. 305) sobre a questão da identidade na mídia e seus reflexos na sala de aula. A autora advoga que a mídia "vem ocupando um espaço cada vez maior na sala de aula, tanto nos materiais didáticos utilizados como nas falas de professores e de alunos". 
volta, a imagem do professor como um lutador solitário ("a professora falando com a parede"). No entanto, após cursar licenciatura, esse mesmo aluno parece rever algumas de suas concepções:

Excerto 62 A5: [...] abriu um pouco/a introdução foi bem isso... foi uma introdução à educação... para mim foi... realmente... apesar de já trabalhar... mas... é aquela história... eu trabalho com aula de inglês... não trabalho com educação né... tanto que:.: isso acabou se refletindo nos meus alunos adolescentes... agora eu... em vez de simplesmente ensinar a matéria... o que eu tenho que ensinar ali... vocabulário... gramática... pronúncia... etc... às vezes eu fíco::: sabe... trabalhando com o próprio modo deles de:.: encarar... o mundo assim... sabe... eu pego muito um pessoal de classe A... A... A... que muitas vezes tem umas idéias que... (eu falo assim) ... "tudo bem mas o que você pensa é um por cento da população que pensa e os outros noventa e nove?" ... "como é que é o resto do mundo em volta de você?" ... e é uma coisa que eu não fazia antes né... quer dizer... isso daí... realmente me afetou...

Vemos no fragmento transcrito (excerto 62) um modo de dizer sobre a licenciatura que produz efeitos associativos à noção de formação. Contudo, cabe ressaltar que a mudança de perspectiva mencionada por esse sujeito parece surtir efeitos imediatos num nicho específico onde ele é professor: a escola de idiomas.

A4, por estar concluindo o curso de letras e iniciando a licenciatura, poderia ser situado entre os alunos do segundo grupo, caracterizado no excerto 56. Vejamos suas formulações sobre esse momento de transição entre os cursos:

Excerto 63 A4: [...] o que espero éh:.:. a interação... porque... no curso de bacharelado a gente tem a parte da pesquisa... do entrosamento da nossa área... na licenciatura... ahn... a gente tem que pensar... como os alunos podem responder... no tempo atual... todo o foco de trabalho em sala... de grupo... e de estágio... é já pensando como uma pré-aula... então fazemos nossos seminários... imaginando como se já estivéssemos ensinando de acordo com aquela teoria que foi ensinada naquele momento...[...] a gente percebe que éh:.: há estímulo... para que a gente faça... há esperança ainda... de se::: tornar professor... principalmente no ensino público... contanto que a::: a aplicabilidade da licenciatura esteja sendo trabalhada conforme... a sociedade a que se propõe...

Além do efeito de divisão entre o bacharelado (pesquisa) e a licenciatura (ensino), suscitada com o segmento acima, há uma imagem do ensino como sendo resultado de um processo alquímico. Num primeiro momento, obtém-se um efeito de transferência dos saberes da área específica ("parte da pesquisa"), para a licenciatura, que, por sua vez, "transforma", ou deve ajudar a transformar, tais conhecimentos teóricos em saberes "práticos" e adaptáveis 
às necessidades da sociedade. Desse modo, há a construção de uma imagem da licenciatura como uma "atividade-meio", isto é, um local mediador, adaptador dos conhecimentos específicos (pesquisa) em "práticos". Tomando ainda a locução conjuntiva condicional "contanto que" iniciando a formulação sobre a "aplicabilidade da licenciatura", temos o efeito de construção de uma imagem da licenciatura como local onde os conhecimentos são pasteurizados e distribuídos na sociedade como produto para consumo. Com isso, tem-se um efeito de desmerecimento do curso de licenciatura, como se ali não fosse local possível de produção de conhecimentos próprios. Em meio a essa alquimia de saberes, a preparação docente parece surgir como um resultado contingente: "há esperança ainda de se tornar professor". Os professores-formadores adquirem, então, estatuto de meros incentivadores, geradores de "esperança" nos alunos para que se tornem professores. Notemos, sobretudo, como tal enunciado parece pertencer a uma região do interdiscurso, aparentemente, vinculada ao discurso religioso.

Outros aparentes efeitos de mudança de perspectiva após o curso de licenciatura e, particularmente, do estágio supervisionado são sugeridos no excerto abaixo:

Excerto 64 A2: [...] o estágio eu acho que me deu um panorama do que é a escola... [...] no início me pareceu assim aquela balbúrdia... aquela coisa que::: ... me parecia muito diferen/tudo era muito diferente do que eu tinha experimentado como aluna... de ensino fundamental e médio... e dentro daquela::: desorganização... digamos assim... não sei se/existe uma organização... mas aos meus olhos... era uma desorganização... eu achei que os alunos tinham muito mais liberdade... proximidade com os professores... [...] é por isso que eu acredito que o local assim... onde existe mais chance de haver transformações... para melhor... é na escola pública... e é onde estão a maioria dos alunos... então eu acredito muito na transformação... MESMO... e eu acho que ela tem mais facilidade de ser... de iniciar na escola pública... exatamente por ser menos controlada... eu achei muito menos controlada e::: e a espontaneidade dos sujeitos envolvidos alí... professor... aluno... eles são muito mais... próximos... e isso foi o estágio que me ajudou a ver...

Há, no segmento apresentado (excerto 64), um efeito associativo à licenciatura decorrente do estágio supervisionado. No entanto, se tomarmos formulações sobre a possibilidade de mudança na escola pública, nota-se uma indeterminação acerca da responsabilidade de tal "transformação". A seqüência de verbos em suas formas nominais (chance de haver, facilidade de ser, de iniciar) atribui uma marca de impersonalização à mudança. Ou seja, há possibilidade de ocorrer, mas o agente de tal mudança permanece anônimo ou está por vir. Valemo-nos uma vez mais de Bauman (2001, p. 153) e suas 
considerações sobre a pós-modernidade: "a mais pungente e menos respondível das questões dos nossos tempos de modernidade líquida não é 'o que fazer?' (para tornar o mundo melhor ou mais feliz), mas 'quem vai fazê-lo?"” Ou seja, não obstante a constatação da necessidade de mudanças, determinando-se inclusive, o local onde elas podem ocorrer (na escola pública), não depreendemos no fio discursivo quem deverá promovê-las.

Concluímos a presente seção, trazendo de volta o título que a nomeia. A1, cursando a terceira licenciatura, conforme expusemos anteriormente, sugere existir o que chamou de "sociedade de segredo", da qual parece passar a fazer parte. Vejamos, primeiramente, o trecho abaixo:

Excerto 65 A1: [...] há outros valores que estão entrando que não mais a instrução... e que eu percebo isso nos alunos... [...] então eu acho que é fundamental nós estarmos na escola [...] eu vejo as professoras da licenciatura... como pessoas que já sabem disso... [...] o fato de elas terem essa consciência quando nós mostramos o relatório... discutimos o relatório... é como se elas já esperassem que a gente trouxesse esse tipo de informação para elas... então eu acho que é uma sociedade de segredo né... tipo... "espera um pouco minha filha... quando você for para escola você vai ver o que é... porque a gente está vendo a teoria..." elas deixam bem claro isso... existe uma teoria... didática... pedagógica... que coloca o aluno... como um ser... que fica sentado na cadeira o tempo todo ouvindo né... [...] na maioria das vezes não é nada disso... então cabe ao professor desenvolver criativamente... estratégias para chamar a atenção do aluno... [...] é uma coisa que é fundamental... você estar numa situação limite que o aluno não está prestando atenção... está conversando... e cabe a você criar um interesse para que esse aluno preste atenção... e é uma coisa que não é ensinada na licenciatura... é uma coisa que você aprende no estágio [...] eu acho que a teoria não vale nada sem a prática... e o que eu pude perceber das minhas professoras da licenciatura é que elas deixaram muito claro... o texto é uma coisa... a teoria é uma coisa... quando você estiver na sala de aula você vai ver... criar de algum lugar o seu ser professor... entendeu? ... a teoria subjaz... porque faz parte do seu conhecimento... mas ao mesmo tempo... essa coisa muito pessoal de cada professor... é importante... e cabe a nós desenvolvermos isso na prática... e isso realmente foi importante em relação aos professores da licenciatura... eles deixaram bem claro... ninguém engana ninguém... foi muito claro... elas foram muito claras desde o começo...

No excerto 65 , obtemos um efeito de responsabilização pela formação centrada na capacidade dos alunos. As características individuais assumem proporções significativas na formação docente, pois há uma representação sobre tornar-se professor como resultado de uma germinação, propiciada por meio do contato com a experiência individual de ensino. Dessa forma, o conhecimento didático-pedagógico parece pré-existir, de maneira estável, portanto, à espera de ser articulado pelo "novo professor". Essa imagem de um saber 
transcendente acessado somente no momento da experiência "prática" de ensino torna a noção de formação um acontecimento lotérico, fortuito. Como garantir acessibilidade a esse saber transcendente? Há, sobretudo, a possibilidade de o novo professor não conseguir acessá-lo. Isso representaria sua não-formação? Como incorporar, então, ao curso de formação, esse saber transcendente, acessado somente após início efetivo do trabalho docente? Qual a necessidade de se mitificar o trabalho docente ("quando você for para escola você vai ver o que é") durante o curso de formação? Há, ainda, de se considerar a possibilidade de o "novo" professor não ser criativo. Estaria, então, esse docente incapacitado de criar "estratégias para chamar a atenção do aluno"? Ou melhor, estaria esse mesmo docente predestinado a ser apontado como o único responsável pelos “insucessos” da não-aprendizagem?

Dessa perspectiva, o professor seria compelido a buscar incessantemente "respostas" para as incertezas do trabalho educacional, na universidade, entre outros lugares. Assim, criase um movimento circular, conforme sugere Sant'Anna (2007, p. 84); ou seja, o professor busca completar sua falta na universidade, mas, uma vez lá, percebe que sua falta também não se completa, pois lhe falta a "prática" que está alhures, ou o saber científico também não corresponde às necessidades específicas do seu cotidiano de ensino. No entanto, sua "culpa" pelo "insucesso" do ensino poderá ser redimida caso continue a buscar "novos modos" de ensinar, uma vez que aqueles adotados não estão surtindo os efeitos esperados. Esse movimento circular de busca acaba por excluir o docente como produtor de conhecimento, uma vez privado (não habilitado) de criar suas próprias respostas. Resta-lhe, então, buscar incessantemente um outro que lhe complete. Nesse sentido, então, esse tipo de busca pela "satisfação" do trabalho docente parece sugerir um efeito semelhante ao phármakon de Derrida (1991). Isto é, depende unicamente do professor encontrar uma "droga curativa" para aplacar os "males" encontrados em sua realidade educacional, estando também responsável pela "dosagem" adequada da droga para não transformá-la em veneno.

\subsection{Considerações acerca da Instituição 2}

Conforme explicamos no início do capítulo, buscamos encaminhar nossa discussão no sentido de mostrar um funcionamento discursivo que sugere a constituição de uma noção de formação condicionada à união de duas faces complementares de um mesmo universo. Observamos que essas duas faces emergem por meio de um movimento associativo/dissociativo no discurso, criando uma imagem na qual a formação do professor de 
inglês é vislumbrada apenas quando essas duas faces se juntam. Por isso a imagem do traumatrópio, título do capítulo, por sugerir uma imagem ilusória que pode se constituir e se manter "estável", contanto que haja uma força constante para colocá-la em movimento. Passemos, então, a sintetizar, brevemente, as duas faces do traumatrópio no discurso ora analisado.

O primeiro aspecto abordado diz respeito ao perfil do aluno de letras. Notamos o efeito de uma padronização sugerida a partir de atributos trazidos por alunos de diversas áreas (ciências sociais, geografia, história, filosofia), que não são encontrados nos alunos originários do curso de letras. Tais atributos dizem respeito a certas posturas críticas e reflexivas no trato de questões educacionais. Desse modo, o aluno de letras parece figurar em uma das faces do traumatrópio, e do outro lado, os demais alunos de outras áreas. Ações pedagógicas são estabelecidas com o objetivo de provocar uma aproximação; no entanto, não encontramos materializações lingüísticas e discursivas sugerindo a união dos "dois pólos", para empregar termo apresentado por Popkewitz (1998). É desse mesmo teórico educacional que tomamos emprestada a noção de "resgate da alma" do aprendiz. É a partir dessa visão crítica que apontamos algumas ações pedagógicas que parecem trazer, no seu cerne, essa concepção. Tais ações constituíam-se em forma de metas educacionais, sugerindo um distanciamento da formação, conforme argumentamos.

Identificamos outro momento, no qual a imagem da formação se constitui a partir da união de duas outras faces, quando o aluno se insere no universo escolar. Dito de outro modo, a licenciatura adquire significados somente quando se está exercendo a docência. Nesse momento da análise, destacamos alguns efeitos de sentido sobre o curso de formação como um bônus universitário, ou ainda sobre o ingresso na carreira docente de modo circunstancial. Destacamos, sobremaneira, a dicotomia entre teoria e prática, como duas faces que somente se unem quando ocorre uma transferência da teoria informada para a prática (sala de aula). Há ênfase, principalmente, para que tal teoria seja factível e apresente bons resultados.

A seleção empreendida pelos alunos para escolher os docentes do curso de licenciatura, além de sugerir representações acerca dos professores-formadores e do curso em si que sugerem um baixo status acadêmico de ambos, tende a reforçar a compartimentalização do conhecimento científico. Cria-se uma imagem de conflito entre a pedagogia e as demais áreas do saber, totalmente improdutiva do nosso ponto de vista. Além disso, o papel do 
professor-formador surge como um fornecedor de "dicas" sobre situações "reais" do espaço escolar. Para o foco deste trabalho, temos aqui, novamente, a imagem do traumatrópio agora constituído pelas faces: arcabouço teórico-linguístico de um lado, e do outro, arcabouço teórico-pedagógico. A partir dessa divisão, identificamos, no discurso, momentos de imprecisão acerca de determinadas ações educativas, fruto, nos parece, da fragmentação universitária. Exemplos ilustrativos dessa imprecisão, encontramos na indefinição quanto à responsabilidade pelo "reparo" pedagógico dos alunos do curso de letras, bem como quanto à interferência da universidade, detentora de um saber institucionalizado, na escola pública (ensino básico). Há ainda outras conseqüências, tais como a perpetuação da noção de professor modelar, excluindo-se, portanto, a agência individual para a construção de conhecimento. Apontamos, também, para o efeito de fragmentação no nível departamental, momento no qual depreendemos uma representação do trabalho docente como um embate individual, ao tomarmos o aspecto da "incomunicação" entre docentes, trazido no discurso.

No decorrer da análise, ao nos aproximarmos dos alunos cujo bacharelado ocorreu em língua inglesa, mostramos a existência de uma "classificação" entre eles. Independentemente da maneira pela qual ela ocorre, entendemos que os processos de hibridização a partir da interação desses grupos, ou ainda, os fatores que possibilitam a convergência de grupos de diferentes origens (nichos educacionais) para a licenciatura são merecedores de mais investigação. Por exemplo, levantamos a hipótese de a falta de clareza dos propósitos do ensino de língua estrangeira na educação básica emergir de tal congregação. Outra questão que também apontamos foi o funcionamento de um tipo de discurso que deprecia a educação pública. Em ambos os casos, o ensino "informal" parece ser um dos beneficiados com tais representações. Diante desse quadro, mais uma vez, chamamos a atenção para o enfrentamento individual do docente ao deparar-se com representações que ajudam a fragilizar e distorcer a noção de formação, de docência e de professor. Demo (1999), por exemplo, reconhece a precariedade da aprendizagem no Brasil. No entanto, defende a nãoresponsabilização unicamente do professor, argumento este utilizado pelos "neoliberais, que se aproveitam dele para manter a situação precária atual” (p. 50).

Levantamos a hipótese de que o discurso da formação já traz no seu bojo a semente do eterno regresso aos bancos escolares. Desse ponto de vista, há um cumprimento fiel à Lei ${ }^{\circ}$ 9394, de 20/12/1996 (LDB): "suscitar o desejo permanente de aperfeiçoamento cultural e profissional" (BRASIL, 1996, Artigo 43, parágrafo V). Nesse sentido, a partir da 
"compreensão" do aluno (licenciando ou bacharelando) sobre a precariedade e transitoriedade do conhecimento na pós-modernidade, ele deve sempre retornar à fonte (não necessariamente acadêmica) para seu reabastecimento, alimentando, com isso, uma cadeia de interesses políticos, econômicos, sociais e culturais. Entendemos que está nas mãos dos educadores investigar se a responsabilização individual pela formação é reflexo de uma atitude docente redentora que busca "conscientizar" o aprendiz para que possa se autogerir ou se é o cumprimento "tácito" de um discurso neoliberal, que mercantiliza os indivíduos, conforme sugere Bianchetti (2001, p. 111).

Diante de tais ponderações, um questionamento se impõe: qual é a extensão da aderência apresentada no discurso da formação de professores a essa noção fluida, temporária, de "curto prazo" a respeito da preparação docente? Considerando a visão discursiva à qual nos filiamos, sabemos que somos perpassados por vários discursos sobre os quais não exercemos controle; porém, isso não deve impedir uma atitude de vigilância sobre determinados funcionamentos discursivos. Para melhor explorar esse aspecto, parece-nos imprescindível, nesse momento, tomarmos contribuição de Foucault (1971/2003a) sobre a "ordem do discurso". Segundo ele, a produção do discurso é organizada por alguns procedimentos (mecanismos discursivos) de controle e delimitação dos discursos. Existe um primeiro grupo cuja função é estabelecer os poderes do discurso, por meio da interdição, da rejeição e da vontade de saber (práticas com suporte institucional). Nesse âmbito, por exemplo, se estabelece "que não se pode falar de tudo em qualquer circunstância" (p. 9). O segundo grupo, trata da dimensão "do acontecimento e do acaso" da aparição do discurso. Nessa dimensão, os procedimentos de controle funcionam para classificar, ordenar e distribuir os discursos. Nesse âmbito, Foucault (2003a, p. 21) discute, por exemplo, o papel do comentário. O terceiro grupo determina as condições de funcionamento dos discursos, isto é, "ninguém entrará na ordem do discurso se não satisfizer a certas exigências ou se não for, de início, qualificado para fazê-lo" (p. 37).

No que tange às condições de funcionamento do discurso, tomando como exemplo o sistema educativo, Foucault (2003a, p. 44) nos alerta sobre a maneira política com que a educação mantém ou modifica "a apropriação dos discursos, com os saberes e os poderes que eles trazem consigo". Isto posto, considerando nossa questão acima sobre a aderência involuntária e inconsciente dos sujeitos e sobre a atitude de vigilância acerca de determinados funcionamentos discursivos, julgando pelos efeitos de sentido obtidos por meio dos 
segmentos apresentados durante nossa análise, acreditamos, sim, na possibilidade de intervenção ou, no mínimo, de vigilância sobre o modo como determinados discursos se repetem por meio do comentário. Vimos salientando que algumas formulações sugerem um efeito de distanciamento da formação, imputando, por conseguinte, ao professor-formador, um papel coadjuvante, submisso a determinadas condições sociais, culturais e educacionais etc. Considerando que alguns dizeres que temos apontado até o momento tornam a formação um acontecimento condicionado a fatores imponderáveis, e sabendo que o comentário permite o retorno de um já dito, dando-lhe ares de "novo", não caberia, então, maior vigilância para tentar entender por que certos dizeres sobrevivem no discurso da formação?

Há um funcionamento discursivo que esboça um painel, no qual as representações ontológicas e epistemológicas acerca da formação e do papel do professor se desenham de modo condicional. Ou seja, a constituição da noção de formação é, indefinidamente, postergada. Primeiramente, em virtude da "compreensão" tardia do significado do curso de licenciatura por parte dos alunos. Em seguida, há um efeito de supervalorização do "resgate da alma" do aprendiz, isto é, busca-se, prioritariamente, o "preenchimento" de uma qualidade ainda não adquirida no aluno do curso de licenciatura. Por fim, pelo fato de o preparo docente estar pautado em conceitos abstratos que não apresentam efeitos de fechamento ou que não são passíveis de concretização imediata.

Tomando o discurso aqui analisado e seu funcionamento, notamos também um efeito de neutralização do curso de licenciatura, em virtude de dizeres que sugerem: a) o curso de formação de professores não se consolida como uma etapa de formação em si; isto é, para os alunos, ele figura como um bônus, uma atividade-meio, uma etapa preventiva ou, simplesmente, uma "nova experiência"; b) os professores-formadores ganham status de fornecedores de regras e dicas que devem ser seguidas na realidade da escola básica; c) o curso de licenciatura deve transformar o conhecimento específico (da unidade de letras, no caso) em conhecimento aplicável no ensino básico; d) o curso de licenciatura adquire estatuto de chancela ao certificar alunos-professores que já possuem experiência de ensino e, finalmente, e) o destino do egresso do curso de licenciatura é desconhecido e há baixa inserção de novos professores na escola básica (objetivo principal do curso de licenciatura).

É nesse sentido que as contribuições de Bourdieu e Champagne (1993/1997) podem nos ajudar. Os autores nos alertam sobre um tipo de funcionamento institucional escolar que 
opera sob "categorias fictícias da aparência, do simulacro" (p. 486). Para esses pensadores, a instituição escolar funciona como uma espécie de "terra prometida" para indivíduos de classes menos favorecidas economicamente. Como esses indivíduos acabam tendo acesso a cursos universitários cujas vagas não são tão disputadas, ao final de um longo período de escolaridade, eles obtêm um diploma, muitas vezes desvalorizado. Daí a noção de "excluídos do interior" por representar uma diferente "versão" de exclusão. Apesar da oportunidade "aparente" da vivência escolar, a chance de tais indivíduos "fracassarem" no universo profissional é alta. A importância da titulação, em detrimento da produção de conhecimento, transforma, então, a certificação em fetiche. É nesse sentido, então, que falamos em constituição de uma aparência de formação, considerando os motivos acima listados.

Evidentemente não queremos insinuar que há uma intenção consciente dos sujeitos envolvidos em simular a preparação profissional. Nosso olhar aqui se volta para os efeitos obtidos por meio de formulações que sugerem uma desvalorização do curso de formação docente, do professor-formador e do futuro professor de inglês. Desejamos concluir o presente capítulo retomando a imagem do traumatrópio. Colocando-nos na posição de seu observador, cabe-nos, então, colocá-lo em movimento a fim de que a imagem da formação possa se delinear com mais precisão e que seus contornos não sejam apenas ilusórios. 


\section{CONCLUSÃO}

Uma leitura precipitada deste trabalho poderá suscitar uma interpretação de que nosso único objetivo é criticar a formação de professores de inglês, assim como seus professoresformadores. Não é disso que tratamos. Portanto, é mister enfatizarmos, novamente, que nosso interesse está centrado no discurso da formação de professores de inglês e seu funcionamento. Se, a partir do nosso diagnóstico ora apresentado, provocarmos educadores a refletirem sobre o interior dos diversos cursos de formação de professores, já é um bom começo para acreditarmos que nosso trabalho não foi em vão. Entendemos o processo de leitura como produção de sentidos, portanto, não há como delimitar possíveis e passíveis representações que a análise que apresentamos possa provocar. Para retomar contribuição de Morin (2006), nosso texto entra agora na "ecologia da ação". Desse modo, a fim de tentarmos contribuir para que alguns deslizamentos tomem rumos mais produtivos educacionalmente, sintetizamos nossas principais discussões.

Lembramos que nossas reflexões estão pautadas em conceitos da AD de orientação pecheutiana, que busca uma articulação do campo lingüístico com o social, incluindo, assim, aspectos históricos, culturais, políticos, econômicos etc. Daí a noção de discurso como "efeitos de sentido entre locutores" (PÊCHEUX, 1997b; ORLANDI, 2002), pois os sentidos não estão determinados no texto, mas nas relações possíveis estabelecidas com tais elementos externos a ele. Consideramos, também, conceitos de pós-modernidade, notadamente, os relacionados ao universo educacional. A partir deles, vimos como vários teóricos entendem que a educação está diante de grandes desafios, pois suas bases estão firmadas em terreno da modernidade. Com isso, destacamos noções que são trazidas à tona, tais como: instabilidade, transitoriedade, imprevisibilidade, incerteza, ambivalência, contingência, entre outras. Diante de tais conceitos, podemos afirmar que a condição pós-moderna pode provocar um efeito de sentido de que a sociedade, as instituições e as relações pessoais foram "desconfiguradas", para emprestar um termo da linguagem tecnológica pós-moderna. Essa "desconfiguração" coletiva traz também seus reflexos para a educação. Nesse campo, então, promulga-se a emergência da reformulação de metas educacionais, curriculares, do papel de agentes educacionais etc. Ou seja, a demanda é por uma "reconfiguração" da educação, assim como das diversas representações a ela atreladas (escola, ensino, professor, aluno etc.). 
Diferentemente do universo da informática, no qual se apaga um programa e se instala um novo, a linguagem não pode ser simplesmente "trocada", pois ela deixa resquícios, marcas, traços de "programas anteriores". Diante disso, a partir da análise empreendida neste trabalho, notamos emergir, do discurso da formação, conflitos de natureza ontológica e epistemológica. Em diversos momentos, centramo-nos em um funcionamento discursivo que permite entrever um conjunto de princípios e procedimentos baseados nos ideais da modernidade. Conforme Kincheloe (1997), na pós-modernidade, professores e alunos devem aprender a produzir conhecimentos próprios e rejeitar procedimentos padronizados, pois todas as verdades são locais e temporárias. Como arriscar-se nas veredas da incerteza, da instabilidade, da contingência sem tornar-se normativo ou adotar uma lógica interna que acabe por revelar fundamentos modernistas de linearidade, de totalidade e de controle? A partir do nosso recorte discursivo e da análise ora concluída, acreditamos que professoresformadores e alunos não sabem, não conseguem ou são incapazes de movimentar-se num terreno de incertezas. Fato este, que os leva, involuntariamente, a ancorar-se nos princípios e fundamentos da modernidade para garantir, mesmo que minimamente, o cumprimento de um ideal de progresso pessoal e a inserção do indivíduo no mercado de trabalho.

A metáfora da linguagem que empregamos acima nos faz ver que de modo semelhante, as representações de ensino, de formação, educação escolar, professor e aluno não são simplesmente trocadas, pois assim sendo, estaríamos apenas colocando outras representações no lugar daquelas. Além disso, não estaríamos sendo "coerentes" com uma perspectiva pós-moderna de educação. Não é possível promover um upgrade em questões educacionais e pessoais sem considerar as implicações, riscos e danos aí envolvidos. Sabemos que transformações históricas acontecem ao longo de anos por meio de pequenas rupturas de amarras políticas, sociais, culturais, econômicas etc. Dessa forma, concluir este trabalho com uma lista de propostas é temerário, falacioso ou, no mínimo, ingênuo. Contudo, reconhecendo o papel da função-autor que nos cabe neste trabalho, como diria Foucault (2006), a partir dos discursos aqui reunidos, trazemos algumas formulações com efeito de conclusão.

Nossa filiação teórica nos ensina sobre a fragmentação do discurso. De fato, é possível observar como diversas vozes coabitam o discurso da formação docente. No entanto, podemos identificar discursos com aparentes efeitos de fechamento e outros com efeitos de adiamento. Nossa análise nos faz ver que o discurso da formação de professores de inglês está entre o segundo grupo. Isso pode ser apenas resultado de uma condição pós-moderna? Nossa 
resposta é negativa, pois se assim o fosse, como ficaria a questão da agência docente? No entanto, conforme analisamos, deparamo-nos com bifurcações de sentidos. Como os sentidos são sempre contingentes, resta-nos a conduta expectante de aguardar e deixar que a formação de professores de inglês ocorra de forma casual, ou é possível inscrever marcas, pequenas rupturas, nesse funcionamento discursivo? Para essa última questão, nossa resposta é afirmativa. Aprendemos com Foucault (2003a) que estamos sob a "ordem do discurso", mas sabemos, também, que assim como há mecanismos discursivos que nos tornam assujeitados, há outros que nos permitem fazer inscrições no discurso. No entanto, julgando pelas vozes que identificamos no discurso aqui analisado, os modos de dizer acerca da formação de professores de inglês a tornam inatingível, distante, mitificada. É nesse sentido que a vemos com efeito de contingente.

Conforme afirmamos, o currículo é o espaço da ambivalência. Desse modo, as pequenas rupturas podem encontrar aí um terreno propício. Bauman (1999a, p. 261) nos diz que a "pós-modernidade é a idade da contingência". Tomando sua asserção, concordamos que, na pós-modernidade, a maior certeza é a incerteza, resgatando reflexões apresentadas por Usher e Edwards (1994), Kincheloe (1997), Morin (2006), entre outros. Nessa linha de pensamento, parece-nos um caminho possível trazer para o currículo a noção de contingência, de incerteza. No entanto, não basta fazer "despertar", por meio do currículo, que tais noções permeiam o trabalho docente de modo inescapável. Antes de tudo, parece-nos necessário fazer o aluno compreender que a noção de contingência é a maior certeza do seu futuro trabalho, para, assim, prepará-lo para agir sobre ela. Pelo que vimos, a formação parece não dar conta de tal preparação, restringindo-se a despertar o desejo de continuar buscando novos meios de se pensar e agir no campo educacional.

Conforme dissemos acima, não podemos desconsiderar amarras de natureza política, social, econômica, institucional, cultural etc., com as quais o docente se depara no seu trabalho. Se essa é, então, uma noção basilar, não seria mais "produtivo" habilitar o futuro professor a ser criador ou gerador de pequenas transformações locais e contextuais? Julgando pelas vozes analisadas, isso não parece acontecer. Pelo discurso, a noção de heteronomia desponta com abrangência. O sentimento de autonomia parece existir no que tange à continuidade pela busca de um elemento outro. Não percebemos um investimento na autonomia para produção de conhecimento, no discurso aqui analisado. Isso pode ser decorrência de uma condição pós-moderna? É possível, pois se as verdades são locais e 
temporárias, faz-se necessário continuar buscando. Entretanto, não se pode perder de vista que, apesar de sermos perpassados por diversos discursos, é possível determinar nosso grau de aderência a eles. Valorizar o aperfeiçoamento contínuo e incessante pode significar o cumprimento de uma concepção de professor idealista e missionário como pode significar também uma aderência ao discurso neoliberal, ou seja, exercer a função ora de cliente, ora de mercadoria, retomando contribuição de Bauman (2005).

Levantamos também várias pesquisas enfatizando o caráter individualista do trabalho docente, ao longo da análise. Conforme Britzman (2003, p. 237), aceitar o diálogo é uma forma de considerar a contingência, ou para retomarmos Bauman (1999a, p. 261), “a contingência requer amizade como alternativa". Sendo assim, outra consideração a fazer diz respeito à questão da solidariedade. De maneiras diferentes, encontramos esse tema em discussões de autores como Kincheloe (1997), Bauman (1999a, 2001, 2004), Rorty (1994), Perrenoud (2000, 2002), para citar apenas alguns. Julgando pelo corpus de nossa pesquisa, o aspecto da solidariedade docente parece inexistir ou é silenciada. Portanto, essa questão, juntamente com o currículo, parecem-nos caminhos possíveis para inscrever pequenos rompimentos de amarras políticas, institucionais, culturais etc.

Ao longo do trabalho, dedicamo-nos a investigar os modos de irrupção da ambivalência no discurso didático-pedagógico e político-educacional. Dessa forma, voltemonos, agora, para a análise documental empreendida. Sabemos que as Diretrizes Curriculares não se propõem a definir procedimentos específicos para a formação de professores e formandos de letras, nem é isso que buscamos. É pertinente enfatizar que não pretendemos defender as orientações ali preconizadas, tampouco rejeitá-las. Conforme dissemos, nosso objetivo foi tomar tais documentos como exemplares de discurso. Assim, fazemos algumas reiterações. Apesar de a noção de flexibilidade figurar como princípio fundante nos documentos, apropriado para uma condição pós-moderna, deparamo-nos com orientações que nos remetem a fundamentos da modernidade, tais como: domínio, controle, totalidade etc. De uma perspectiva discursiva, tal dissonância de vozes não nos causa estranhamento. Há de se ressaltar que essas vozes são representativas de um conflito de paradigmas da pósmodernidade, sobretudo, no campo educacional. Contudo, o surgimento de conceitos que demandam escrutínio e constante reflexão, ao lado de orientações pontuais com efeitos de sentido afinados com interesses mercadológicos, além de poder render uma noção de performatização à formação do professor de inglês, pode também estimular ideais 
modernistas, por parecerem mais "seguros", levando a uma perpetuação de representações tais como as trazidas no discurso didático-pedagógico, apontadas neste trabalho: impossibilidade e adiamento da formação do professor de inglês, responsabilização individual pela formação, depreciação da licenciatura, do professor-formador, do ensino público e do seu professor, com conseqüente valorização do ensino "informal" e do seu professor.

Nossa análise sugere, também, que o discurso da formação de professores de inglês se apresenta como duas faces de um traumatrópio. Sabemos que isso não é privilégio do discurso educacional, pois como dissemos, somos constituídos por amarras históricas, políticas, sociais etc.; desse modo, estamos sempre entre fronteiras, contemplando diferentes dimensões, em diversos universos sociais. Porém, a questão é pensar sobre a intensidade com a qual colocaremos o traumatrópio em movimento a fim de tornar sua imagem mais acentuada e evidente. Considerando que a noção de formação docente não envolve apenas o saber didático e pedagógico, entendemos encontrar na intensificação desse movimento, um caminho para a desconstrução de polarizações. Dessa forma, defendemos o investimento em modos que estimulem maior aproximação e aumento de diálogos entre diferentes saberes educacionais para a melhoria da formação docente - uma porta aberta para futuros olhares preocupados com a formação de professores, especialmente, professores de língua inglesa. 


\section{REFERÊNCIAS BIBLIOGRÁFICAS}

ABBAGNANO, N. Dicionário de filosofia. 4. ed. Trad. Ivone C. Benedetti. São Paulo: Martins Fontes, 2000. Tradução de: Dizionario di filosofia.

AMORIM, A. C. R. Photo grafias, escritascotidiano e currículos deformação. In: FERRAÇO, C. E. (Org.). Cotidiano escolar, formação de professores(as) e currículo. São Paulo: Cortez, 2005, p. 112-127. (Cultura, memória e currículo, v. 6).

APPLE, M. W. A política do conhecimento oficial: faz sentido a idéia de um currículo nacional? In: MOREIRA, A. F. B.; SILVA, T. T. (Org.). Currículo, cultura e sociedade. São Paulo: Cortez, 1994, p. 59-91.

ANDERSON, P. (1998). As origens da pós-modernidade. Trad. Marcus Penchel. Rio de Janeiro: Jorge Zahar, 1999. Tradução de: The origins of postmodernity.

ANDREI, E. (Ed.). Dicionário médico Blakiston. 2. ed. São Paulo: Andrei, [1979].

AUSTIN, J. L. (1962). Quando dizer é fazer: palavras e ação. Trad. Danilo M. de Souza Filho. Porto Alegre: Artes médicas, 1990. Tradução de: How to do things with words.

AUTHIER-REVUZ, J. Entre a transparência e a opacidade: um estudo enunciativo do sentido. Trad. (Revisão técnica) Leci B. Barbisan e Valdir N. Flores. Porto Alegre: EDIPUCRS, 2004.

. (1998). Palavras incertas: as não-coincidências do dizer. Trad. Claudia R. C. Pfeiffer et al. Campinas: Ed. da UNICAMP, 2001.

AZEVEDO, F. M. T. A concepção de contingência em Richard Rorty. 2007. Dissertação (Mestrado em Filosofia) - Pontifícia Universidade Católica do Rio de Janeiro, Rio de Janeiro, 2007. Disponível em: http://www.maxwell.lambda.ele.puc-rio.br/cgi-

bin/db2www/PRG_0991.D2W/SHOW?Cont=10499:pt\&Mat=\&Sys $=\& N r=\& F u n=\& C d L i n P r$ $\mathrm{g}=\mathrm{pt}>$. Acesso em: 20 nov. 2007.

BAGHIN-SPINELLI, D. C. M. O professor de língua inglesa em formação e sua relação com o dizer nessa língua-alvo: um estudo dos silenciamentos nas práticas de ensino. Crop: Revista da área de língua e literatura inglesa e norte-americana do Departamento de Letras Modernas/FFLCH/USP. São Paulo: Humanitas/FFLCH/USP, 2003, n. 9, p. 189-220.

BAKHTIN, M. (Volochínov, 1929). Marxismo e filosofia da linguagem. 11. ed. Trad. Michel Lahud e Yara F. Vieira. São Paulo: Hucitec, 2004.

. (1979). A estética da criação verbal. 4. ed. Trad. Paulo Bezerra. São Paulo: Martins Fontes, 2003. Tradução de: Estetika esloviésnova tvórtchestva.

BARCELOS, A. M. F.; BATISTA, F. S.; ANDRADE, J. C. Ser professor de inglês: crenças, expectativas e dificuldades dos alunos de letras. In: ABRAHÃO, M. H. V. (Org.). Prática de ensino de língua estrangeira: experiências e reflexões. Campinas, SP: Pontes; ArteLíngua, 2004, p. 11-29. 
BARRETO, R. G. A presença das tecnologias. In: FERRAÇO, C. E. (Org.). Cotidiano escolar, formação de professores(as) e currículo. São Paulo: Cortez, 2005, p. 141-157. (Cultura, memória e currículo, v. 6).

BARROS, M. E. B. Formação de professores/as e os desafios para a (re)invenção da escola. In: FERRAÇO, C. E. (Org.). Cotidiano escolar, formação de professores(as) e currículo. São Paulo: Cortez, 2005, p. 68-93. (Cultura, memória e currículo, v. 6).

BARTHES, R. Lição. Trad. Ana M. Leite. Lisboa: Edições 70, 1979. Tradução de: Leçon.

BAUMAN, Z. (1997). O mal-estar da pós-modernidade. Trad. Mauro Gama e Cláudia M. Gama. Rio de Janeiro: Jorge Zahar, 1998. Tradução de: Postmodernity and its discontents.

(1991). Modernidade e ambivalência. Trad. Marcus Penchel. Rio de Janeiro: Jorge Zahar, 1999a. Tradução de: Modernity and ambivalence.

. (1998). Globalização: as conseqüências humanas. Trad. Marcus Penchel. Rio de Janeiro: Jorge Zahar, 1999b. Tradução de: Globalization: the human consequences.

. (2000). Modernidade líquida. Trad. Plínio Dentzien. Rio de Janeiro: Jorge Zahar, 2001. Tradução de: Liquid modernity.

. (2003). Amor líquido: sobre a fragilidade dos laços humanos. Trad. Carlos A. Medeiros. Rio de Janeiro: Jorge Zahar, 2004. Tradução de: Liquid love: on the frailty of human bonds.

(2004). Identidade: entrevista a Benedetto Vecchi. Trad. Carlos A. Medeiros. Rio de Janeiro: Jorge Zahar, 2005. Tradução de: Identity (conversations with Benedetto Vecchi).

BENVENISTE, E. (1966). O homem na língua. In: . Problemas de lingüistica geral I. 4. ed. Trad. Maria G. Novak e Maria L. Neri. Campinas: Pontes; Ed. da UNICAMP, 1995, p. 245-315. Tradução de: Problèmes de linguistique générale.

BERTOLDO, E. S. O discurso pedagógico da lingüística aplicada. In: CORACINI, M. J.; BERTOLDO, E. S. (Org.). O desejo da teoria e a contingência da prática: discursos sobre e na sala de aula: (língua materna e língua estrangeira). Campinas: Mercado de Letras, 2003, p. 161-189.

BHABHA, H. K. (1994). O local da cultura. Trad. Myriam Ávila, Eliana L. L. Reis e Gláucia R. Gonçalves. Belo Horizonte: Ed. da UFMG, 2007. Tradução de: The location of culture. Coleção Humanitas, 4. reimpr.

BIANCHETTI, R. G. Modelo neoliberal e politicas educacionais. 3. ed. São Paulo: Cortez, 2001. (Questões da nossa época, v. 56).

BOURDIEU, P.; CHAMPAGNE, P. (1993). Os excluídos do interior. In: BOURDIEU, P. et al. A miséria do mundo. Trad. Mateus S. Soares Azevedo et al. Petrópolis, RJ: Vozes, 1997, p. 481-486. Tradução de: La misère du monde. 
BRANDÃO, H. H. N. (1991). Introdução à análise do discurso. 5. ed. Campinas: Ed. da UNICAMP, 1996.

. (1997). Subjetividade, argumentação, polifonia. A propaganda da Petrobrás. São Paulo: Ed. da UNESP: Imprensa Oficial do Estado, 1998.

Texto, gêneros do discurso e ensino. In: . (Coord.). Gêneros do discurso na escola: mito, conto, cordel, discurso político, divulgação científica. São Paulo: Cortez, 2000, p. 17-45. (Aprender e ensinar com textos, v. 5).

BRASIL. Lei ${ }^{0}$ 9.394, de 20 de dezembro de 1996. Estabelece as diretrizes e bases da educação nacional. Diário Oficial da União, Brasília, DF, 23 dez. 1996. Disponível em: $<$ http://www.planalto.gov.br/CCIVIL_03/LEIS/L9394.htm>. Acesso em: 10 jan.2008.

BRASIL. Decreto 3.276, de 06 de dezembro de 1999. Dispõe sobre a formação em nível superior de professores para atuar na educação básica, e dá outras providências. Diário Oficial da União, Brasília, DF, 7 dez. 1999. Disponível em: $<$ http://portal.mec.gov.br/cne/arquivos/doc/decr3276_99.doc $>$. Acesso em: 10 jan.2008.

BRASIL. Lei $\mathrm{n}^{\mathrm{o}}$ 10.172, de 9 de janeiro de 2001. Aprova o Plano Nacional de Educação e dá outras providências. Diário Oficial da União, Brasília, DF, 10 jan. 2001. Disponível em: $<$ http://www.planalto.gov.br/ccivil/LEIS/LEIS_2001/L10172.htm>. Acesso em: 10 jan.2008.

BRITZMAN, D. P. Practice makes practice: the given and the possible in teacher education. In:__ Practice makes practice: a critical study of learning to teach (revised edition). Albany: State University of New York Press, 2003, p. 221-241.

BRUNER, J. (1996). A cultura da educação. Trad. Marcos A. G. Domingues. Porto Alegre: Artmed, 2001. Tradução de: The culture of education.

CACHAPUZ, A. F. A universidade, a valorização do ensino e a formação dos seus docentes. In: SHIGUNOV NETO, A.; MACIEL, L. S. B. (Org.). Reflexões sobre a formação de professores. Campinas: Papirus, 2002, p. 115-139. (Magistério: formação e trabalho pedagógico).

CAMPOS, A. M. Accountability: quando poderemos traduzi-la para o português? Revista de administração pública, Rio de Janeiro, v. 24, n. 2, p. 30-50, fev./abr. 1990.

CANEN, A. Sentidos e dilemas do multiculturalismo: desafios curriculares para o novo milênio. In: LOPES, A. C.; MACEDO, E. (Org.). Currículo: debates contemporâneos. 2. ed. São Paulo: Cortez, 2005, p. 174-195. (Cultura, memória e currículo, v. 2).

CARDOSO, S. H. B. (1999). Discurso e ensino. 2. ed. Belo Horizonte: Autêntica, 2003.

CARMAGNANI, A. M. G. A questão da identidade na mídia: reflexos na sala de aula. In: CORACINI, M. J. (Org.). Identidade e discurso: (des)construindo subjetividades. Campinas: Ed. da UNICAMP; Chapecó: Argos Ed. Universitária, 2003, p. 305-317. 
CARVALHO, J. M. Pensando o currículo escolar a partir do outro que está em mim. In: FERRAÇO, C. E. (Org.). Cotidiano escolar, formação de professores(as) e currículo. São Paulo: Cortez, 2005, p. 94-111. (Cultura, memória e currículo, v. 6).

CHARAUDEAU, P.; MAINGUENEAU, D. Dicionário de análise do discurso. Trad. (Coord.) Fabiana Komesu. São Paulo: Contexto, 2004. Tradução de: Dictionnaire d'analyse du discours.

CHEN, Y. Changing patterns of power: rethinking decentralization in the educational reform in Taiwan. In: LINDBLAD, S.; POPKEWITZ, T. S. (Ed.). Educational restructuring: international perspectives on traveling policies. Greenwich, Connecticut: Information Age Publishing, 2004, p. 43-68.

CHEVALLARD, Y. La transposition didactique: du savoir savant au savoir enseigné. (Suivie de Yves Chevallard et Marie-Alberte Johsua: Un exemple d'analyse de la transposition didactique). [Grenoble]: La Pensée Sauvage, 1991.

COCHRAN-SMITH, M.; LYTLE, S. L. Troubling images of teaching in no child left behind. Harvard educational review, Cambridge, v. 76, n. 4, p. 668-697, winter 2006.

COMISSION OF THE EUROPEAN COMMUNITIES. White paper on education and training: teaching and learning: towards the learning society. Brussels, 29 Nov. 1995 COM (95), 590 final. Disponível em:

$<$ http://aei.pitt.edu/1132/01/education_train_wp_COM_95_590.pdf $>$ Acesso em: 17 out. 2007.

CONSELHO NACIONAL DE EDUCAÇÃO / CÂMARA DE EDUCAÇÃO SUPERIOR. Parecer CNE/CES 492/2001. Diretrizes Curriculares Nacionais dos cursos de Filosofia, História, Geografia, Serviço Social, Comunicação Social, Ciências Sociais, Letras, Biblioteconomia, Arquivologia e Museologia. Diário Oficial da União, Brasília, DF, 9 jul. 2001. Seção 1e, p. 50. Disponível em:

$<$ http://portal.mec.gov.br/cne/arquivos/pdf/CES492.pdf> Acesso em: 10 jan.2008.

CONSELHO NACIONAL DE EDUCAÇÃO / CÂMARA DE EDUCAÇÃO SUPERIOR. Resolução CNE/CES 18, de 13 de março de 2002. Estabelece as Diretrizes Curriculares para os cursos de Letras. Diário Oficial da União, Poder Executivo, Brasília, DF, 9 abr. 2002. Seção 1, p. 34. Disponível em: <http://portal.mec.gov.br/cne/arquivos/pdf/CES182002.pdf>. Acesso em: 10 jan.2008.

CONSELHO NACIONAL DE EDUCAÇÃO / CONSELHO PLENO. Resolução CNE/CP 1, de 18 de fevereiro de 2002. Institui Diretrizes Curriculares Nacionais para a Formação de Professores da Educação Básica, em nível superior, curso de licenciatura, de graduação plena. Diário Oficial da União, Poder Executivo, Brasília, DF, 9 abr. 2002a. Seção 1, p. 31. Disponível em: $<$ http://portal.mec.gov.br/cne/arquivos/pdf/CP012002.pdf $>$. Acesso em: 10 jan.2008.

CONSELHO NACIONAL DE EDUCAÇÃO / CONSELHO PLENO. Resolução CNE/CP 2, de 19 de fevereiro de 2002. Institui a duração e a carga horária dos cursos de licenciatura, de graduação plena, de formação de professores da Educação Básica em nível superior. Diário 
Oficial da União, Poder Executivo, Brasília, DF, 4 mar. 2002b. Seção 1, p. 9. Disponível em: $<$ http://portal.mec.gov.br/cne/arquivos/pdf/CP022002.pdf $>$. Acesso em: 10 jan.2008.

CORACINI, M. J. R. F. Um fazer persuasivo: o discurso subjetivo da ciência. São Paulo: EDUC; Campinas: Pontes, 1991.

. (Org.). Interpretação, autoria e legitimação do livro didático: língua materna e língua estrangeira. Campinas: Pontes, 1999a.

. O processo de legitimação do livro didático na escola de ensino fundamental e médio: uma questão de ética. In: (Org.). Interpretação, autoria e legitimação do livro didático: língua materna e língua estrangeira. Campinas: Pontes, 1999b, p. 33-43.

. A abordagem reflexiva na formação do professor de língua. In:

BERTOLDO, E. S. (Org.). O desejo da teoria e a contingência da prática: discursos sobre e na sala de aula: (língua materna e língua estrangeira). Campinas: Mercado de Letras, 2003a, p. 305-327.

. A consciência crítica nos discursos sobre e da sala de aula. In: ; BERTOLDO, E. S. (Org.). O desejo da teoria e a contingência da prática: discursos sobre e na sala de aula: (língua materna e língua estrangeira). Campinas: Mercado de Letras, 2003b, p. 271-289.

; BERTOLDO, E. S. (Org.). O desejo da teoria e a contingência da prática: discursos sobre e na sala de aula: (língua materna e língua estrangeira). Campinas: Mercado de Letras, $2003 \mathrm{c}$.

CORACINI, M. J. Pós-modernidade e novas tecnologias - no discurso do professor de línguas. In:__. A celebração do outro: arquivo, memória e identidade: línguas (materna e estrangeira), plurilingüismo e tradução. Campinas: Mercado de Letras, 2007, p. 209-224.

CORAZZA, S. M. Diferença pura de um pós-currículo. In: LOPES, A. C.; MACEDO, E. (Org.). Currículo: debates contemporâneos. 2. ed. São Paulo: Cortez, 2005, p. 103-114. (Cultura, memória e currículo, v. 2).

COSTA, M. V. Poder, discurso e política cultural: contribuições dos estudos culturais ao campo do currículo. In: LOPES, A. C.; MACEDO, E. (Org.). Currículo: debates contemporâneos. 2. ed. São Paulo: Cortez, 2005, p. 133-149. (Cultura, memória e currículo, v. 2).

COURTINE, J. J. Quelques problèmes théoriques et méthodologiques en analyse du discours, à propos du discours communiste adressé aux chrétiens. Langages, Paris, n. 62, p. 9-128, 1981.

DEBORD, G. (1992). A sociedade do espetáculo. Trad. Estela dos Santos Abreu. Rio de Janeiro: Contraponto, 1997. Tradução de: La société du spectacle.

DELIBO, J. A. Formação e prática do professor de inglês: repensando o espaço da língua materna. 1999. Tese (Doutorado em Educação) - Faculdade de Educação, Universidade de São Paulo, São Paulo, 1999. 
DEMO, P. (1997). A nova LDB: ranços e avanços. 8. ed. Campinas, SP: Papirus, 1999. (Magistério: formação e trabalho pedagógico).

DERRIDA, J. (1972). A farmácia de Platão. Trad. Rogério da Costa. São Paulo: Iluminuras, 1991. Tradução de: La pharmacie de Platon.

DUCROT, O. (1972). Princípios de semântica lingüistica (dizer e não dizer). Trad. Carlos Vogt, Rodolfo Ilari e Rosa A. Figueira. São Paulo: Cultrix, 1977. Tradução de: Dire et ne pas dire: principes de sémantique linguistique.

(1984). O dizer e o dito. Trad. (Revisão técnica) Eduardo Guimarães. Campinas: Pontes, 1987. Tradução de: Le dire et le dit.

DUSSEL, I. Educational restructuring and the reshaping of school governance in Argentina. In: LINDBLAD, S.; POPKEWITZ, T. S. (Ed.). Educational restructuring: international perspectives on traveling policies. Greenwich, Connecticut: Information Age Publishing, 2004, p. 3-20.

. O currículo híbrido: domesticação ou pluralização das diferenças? Trad. Alice C. Lopes e Elizabeth Macedo. In: LOPES, A. C.; MACEDO, E. (Org.). Currículo: debates contemporâneos. 2. ed. São Paulo: Cortez, 2005, p. 55-77. (Cultura, memória e currículo, v. 2).

ESTRELA, M. T. A investigação como estratégia de formação contínua de professores: reflexão sobre uma experiência. In: SHIGUNOV NETO, A.; MACIEL, L. S. B. (Org.). Reflexões sobre a formação de professores. Campinas: Papirus, 2002, p. 141-172. (Magistério: formação e trabalho pedagógico).

EURÍPIDES. Medéia. Trad. Edvanda B. da Rosa. Araraquara: FCL/UNESP, 1995. (Giz-enscène, v. 4).

FERRATER MORA, J. Dicionário de filosofia. Trad. Maria Stela Gonçalves et al. São Paulo: Loyola, 2000, p. 567-568. Tradução de: Diccionario de filosofía.

FERRAÇO, C. E. Currículo, formação continuada de professores e cotidiano escolar: fragmentos de complexidade das redes vividas. In: (Org.). Cotidiano escolar, formação de professores(as) e currículo. São Paulo: Cortez, 2005, p. 15-42. (Cultura, memória e currículo, v. 6).

FERRO, G. D. M. A formação do professor de inglês: trajetória da prática de ensino de inglês na Universidade de São Paulo. 1998. Tese (Doutorado em Educação) - Faculdade de Educação, Universidade de São Paulo, São Paulo, 1998.

FIORIN, J. L. (2002). A linguagem em uso. In: ed. São Paulo: Contexto, 2006, p. 165-186. . (Org.). Introdução à lingüística. 5.

FOUCAULT, M. (1969). O que é um autor? In: MOTTA, M. B. (Org.). Estética: literatura e pintura, música e cinema / Michel Foucault. 2. ed. Trad. Inês A. D. Barbosa. Rio de Janeiro: Forense Universitária, 2006, p. 264-298. (Ditos e escritos III). 
. (1969). A arqueologia do saber. 7. ed. Trad. Luiz Felipe B. Neves. Rio de Janeiro: Forense Universitária, 2007. Tradução de: L’archéologie du savoir. (Campo Teórico).

(1971). A ordem do discurso. 9. ed. Trad. Laura F. A. Sampaio. São Paulo: Loyola, 2003a. Tradução de: L'ordre du discours.

. (1975). Vigiar e punir: nascimento da prisão. 27. ed. Trad. Raquel Ramalhete.

Petrópolis: Vozes, 2003b. Tradução de: Surveiller et punir.

(1979). Governamentalidade. In: MACHADO, R. (Org.). Microfísica do poder. 18. ed. Trad. Roberto Machado. Rio de Janeiro: Graal, 2003c, p. 277-293.

. (1979). Verdade e poder. In: MACHADO, R. (Org.). Microfisica do poder. 18. ed. Trad. Roberto Machado. Rio de Janeiro: Graal, 2003d, p. 1-14.

(1979). Soberania e disciplina. In: MACHADO, R. (Org.). Microfísica do poder. 18. ed. Trad. Roberto Machado. Rio de Janeiro: Graal, 2003e, p. 179-191.

. (1982). The subject and power. In: DREYFUS, H. L.; RABINOW, P. Michel Foucault: beyond structuralism and hermeneutics. 2nd ed. Chicago: The University of Chicago Press, 1983, p. 208-226 (afterword).

GARCIA, M. M. A. A didática no ensino superior. Campinas: Papirus, 1994.

GERALDI, J. W. Portos de passagem. São Paulo: Martins Fontes, 1991. (Texto e liguagem).

GIROUX, H. A. (1988). Os professores como intelectuais: rumo a uma pedagogia crítica da aprendizagem. Trad. Daniel Bueno. Porto Alegre: Artes Médicas, 1997. Tradução de: Teachers as intellectuals: toward a critical pedagogy of learning.

GRIGOLETTO, M. A resistência das palavras: discurso e colonização britânica na Índia. Campinas: Ed. da UNICAMP, 2002.

. Um saber sobre os sujeitos: práticas de subjetivação no discurso político-educacional sobre línguas estrangeiras. In: SEMINÁRIO INTERNACIONAL MICHEL FOUCAULT: PERSPECTIVAS, 2004, Florianópolis. Anais. Florianópolis: UFSC, 2004. p. 453-459.

GUILHON ALBUQUERQUE, J. A. Instituição e poder: a análise concreta das relações de poder nas instituições. Rio de Janeiro: Graal, 1980. (Biblioteca de Filosofia e história das ciências, v. 10).

GUIMARÃES, E. (2002). Semântica do acontecimento: um estudo enunciativo da designação. 2. ed. Campinas: Pontes, 2005.

GUIMARÃES, V. S. Formação de professores: saberes, identidade e profissão. Campinas: Papirus, 2004. (Entre nós professores).

GUIRADO, M. A clínica psicanalítica na sombra do discurso: diálogos com aulas de Dominique Maingueneau. São Paulo: Casa do psicólogo, 2000. 
HALL, S. (Ed.). Representation: cultural representations and signifying practices. New York: Sage Publications, 1997.

HENRY. P. (1975). Construções relativas e articulações discursivas. Trad. João W. Geraldi e Celene M. Cruz. Cadernos de estudos lingüísticos. Campinas: Ed. da UNICAMP, n. 19, p. 43-64, jul./dez. 1990.

HOUAISS, A.; MELLO FRANCO, F. M.; VILLAR, M. S. (Ed.). Dicionário eletrônico Houaiss da língua portuguesa. Versão 1.0. [Rio de Janeiro]: Objetiva, 2001. CD-ROM.

HOUSSAYE, J. (2002). Pedagogia: justiça para uma causa perdida? In: et al. Manifesto a favor dos pedagogos. Trad. Vanise Dresch. Porto Alegre: Artmed, 2004, p. 9-45. Tradução de: Manifeste pour les pédagogues.

INDURSKY, F. A fragmentação do sujeito em análise do discurso. In: ; CAMPOS, M. C. (Org.). Discurso, memória, identidade. Porto Alegre: Sagra Luzzatto, 2000, p. 70-81.

KERBRAT-ORECCHIONI, C. L'énonciation: de la subjectivité dans le langage. Paris: Librairie Armand Colin, 1980. . L'implicite. Paris: Librairie Armand Colin, 1986.

KINCHELOE, J. L. (1993). A formação do professor como compromisso político: mapeando o pós-moderno. Trad. Nize M. C. Pellanda. Porto Alegre: Artes Médicas, 1997. Tradução de: Toward a critical politics of teacher thinking: mapping the postmodern.

KIZILTAN, M. Ü.; BAIN, W. J.; CAÑIZARES M., A. Condições pós-modernas: repensando a educação pública. Trad. Tomaz T da Silva. In: SILVA, T. T. (Org.). Teoria educacional crítica em tempos pós-modernos. Porto Alegre: Artes Médicas, 1993, p. 205-232.

KOCH, I. G. V. (1984). Argumentação e linguagem. 8. ed. São Paulo: Cortez, 2002.

LALANDE, A. Vocabulário técnico e crítico da filosofia. 3. ed. Trad. Fátima Sá Correia et al. São Paulo: Martins Fontes, 1999, p. 203-204. Tradução de: Vocabulaire technique et critique de la philosophie.

LARANJEIRA, M. I. Diretrizes curriculares nacionais para a formação de professores: entre a ambição e a realidade ou sobre a coerência e a facilidade. 2003. Tese (Doutorado) Faculdade de Filosofia e Ciências, Universidade Estadual Paulista, Marília, SP, 2003.

LEITE, C. O currículo e o exercício profissional docente face aos desafios sociais desta transição de século. In: FERRAÇO, C. E. (Org.). Cotidiano escolar, formação de professores(as) e currículo. São Paulo: Cortez, 2005, p. 128-140. (Cultura, memória e currículo, v. 6).

LINDBLAD, S.; POPKEWITZ, T. S. (Ed.). Educational restructuring: international perspectives on traveling policies. Greenwich, Connecticut: Information Age Publishing, 2004a. 
; __ Educational restructuring: (re)thinking the problematic of reform. In:

; . (Ed.). Educational restructuring: international perspectives on traveling

policies. Greenwich, Connecticut: Information Age Publishing, 2004b, p. vii-xxxi

(introduction).

$\overline{\mathrm{In}} \quad ; \quad \ldots \quad$ Education restructuring: governance in the narratives of progress and denials. policies. Greenwich, Connecticut: Information Age Publishing, 2004c, p. 69-94.

LOPES, A. C.; MACEDO, E. (Org.). Currículo: debates contemporâneos. 2. ed. São Paulo: Cortez, 2005a. (Cultura, memória e currículo, v. 2).

; _ O pensamento curricular no Brasil. In: ; . (Org.). Currículo: debates contemporâneos. 2. ed. São Paulo: Cortez, 2005b, p. 13-54. (Cultura, memória e currículo, v. 2).

; $\quad$ Pensamento e política curricular: entrevista com William Pinar. In: . (Org.). Políticas de currículo em múltiplos contextos. São Paulo: Cortez, $\overline{2006, \mathrm{p}}$. 13-37. (Cultura, memória e currículo, v. 7).

LYOTARD, J. F. (1979). O pós-moderno. Trad. Ricardo C. Barbosa. Rio de Janeiro: José Olympio, 1986. Tradução de: La condition postmoderne.

MACEDO, E. F. Novas tecnologias e currículo. In: MOREIRA, A. F. B. (Org.). Currículo: questões atuais. Campinas: Papirus, 1997, p. 39-58. (Magistério: formação e trabalho pedagógico).

MAGUIRE, M. The modern teacher: a textual analysis of educational restructuration. In: LINDBLAD, S.; POPKEWITZ, T. S. (Ed.). Educational restructuring: international perspectives on traveling policies. Greenwich, Connecticut: Information Age Publishing, 2004, p. 121-141.

MAINGUENEAU, D. (1998). Análise de textos de comunicação. 3. ed. Trad. Cecília P. de Souza-e-Silva e Décio Rocha. São Paulo: Cortez, 2004. Tradução de: Analyser les textes de communication.

MALDIDIER, D. A inquietação do discurso: re(ler) Michel Pêcheux hoje. Trad. Eni P. Orlandi. Campinas: Pontes, 2003.

MASCIA, M. A. A. Investigações discursivas na pós-modernidade: uma análise das relações de poder-saber do discurso político educacional de língua estrangeira. Campinas, SP:

Mercado de Letras; São Paulo: Fapesp, 2002.

MCLAREN, P. Teoria crítica e o significado da esperança. In: GIROUX, H. A. Os professores como intelectuais: rumo a uma pedagogia crítica da aprendizagem. Trad. Daniel Bueno. Porto Alegre: Artes Médicas, 1997, p. xi-xxi (prefácio). Tradução de: Teachers as intellectuals: toward a critical pedagogy of learning. 
MCLENNAN, G. (1992). The enlightenment project revisited. In: HALL, S.; HELD, D.; MCGREW, T. (Ed.). Modernity and its futures. Cambridge: The Open University, [1996?], p. 328-377.

MENEZES DE SOUZA, L. M. T. Hibridismo e tradução cultural em Bhabha. In: ABDALA JÚNIOR, B. (Org.). Margens da cultura: mestiçagem, hibridismo e outras misturas. São Paulo: Boitempo, 2004, p. 113-133.

MILNER, J. C. (1978). O amor da língua. Trad. Ângela C. Jesuíno. Porto Alegre: Artes Médicas, 1987. Tradução de: L'amour de la langue.

MONTE MÓR, W. A mediação entre a teoria e a prática no ensino de línguas estrangeiras. Crop: Revista da área de língua e literatura inglesa e norte-americana do Departamento de Letras Modernas/FFLCH/USP. São Paulo: Humanitas/FFLCH/USP, 2006, n. 11, p. 347-361.

MOREIRA, A. F. B.; SILVA, T. T. Sociologia e teoria crítica do currículo: uma introdução. In: . (Org.). Currículo, cultura e sociedade. São Paulo: Cortez, 1994, p. 7-37.

MORIN, E. (1999). A cabeça bem-feita: repensar a reforma, reformar o pensamento. Trad. Eloá Jacobina. Rio de Janeiro: Bertrand Brasil, 2000. Tradução de: La tête bien faite: repenser la réforme, réformer la pensée.

. (1999). Os sete saberes necessários à educação do futuro. 11. ed. Trad. Catarina E. F. da Silva e Jeanne Sawaya. São Paulo: Cortez; Brasília, DF: UNESCO, 2006. Tradução de: Les sept savoirs nécessaires à l'education du futur.

MULLER, J. Responsiveness and innovation in higher education restructuring: the South African case. In: LINDBLAD, S.; POPKEWITZ, T. S. (Ed.). Educational restructuring: international perspectives on traveling policies. Greenwich, Connecticut: Information Age Publishing, 2004, p. 143-165.

NÓVOA, A. (Coord.) (1992). Os professores e a sua formação. 2. ed. Lisboa: Publicações Dom Quixote, 1995.

OLIVEIRA, I. B. Criação curricular, autoformação e formação continuada no cotidiano escolar. In: FERRAÇO, C. E. (Org.). Cotidiano escolar, formação de professores(as) e currículo. São Paulo: Cortez, 2005, p. 43-67. (Cultura, memória e currículo, v. 6).

ORLANDI, E. P. (1983). A linguagem e seu funcionamento: as formas do discurso. 4. ed. Campinas: Pontes, 2006.

. Segmentar ou recortar. Série Estudos, Uberaba, n. 10, p. 9-26, 1984.

2001. . (1988). Discurso e leitura. 6. ed. São Paulo: Cortez; Campinas: Ed. da UNICAMP, . (1992). As formas do silêncio: no movimento dos sentidos. 4. ed. Campinas: Ed. da UNICAMP, 1997. 

2002.

(1999). Análise de discurso: princípios e procedimentos. 4. ed. Campinas: Pontes,

PAIVA, E. V.; FRANGELLA, R. C. P.; DIAS. R. E. Políticas curriculares no foco das investigações. In: LOPES, A. C.; MACEDO, E. (Org.). Políticas de currículo em múltiplos contextos. São Paulo: Cortez, 2006, p. 241-269. (Cultura, memória e currículo, v. 7).

PASSOS, D. M. S. P. Linguagem, política e ecologia: uma análise do discurso de partidos verdes. São Paulo: FFLCH/USP; Campinas: Pontes, 2006.

PÊCHEUX, M. (1969). Análise automática do discurso (AAD-69). In: GADET, F.; HAK, T. (Org.). Por uma análise automática do discurso: uma introdução à obra de Michel Pêcheux. 3. ed. Trad. Bethânia S. Mariani et al. Campinas: Ed. da UNICAMP, 1997a, p. 61-105. Tradução de: Towards an automatic discurse analysis.

(1975). Semântica e discurso: uma crítica à afirmação do óbvio. 3. ed. Trad. Eni P. Orlandi et al. Campinas: Ed. da UNICAMP, 1997b. Tradução de: Les vérités de la Palice.

; FUCHS, C. (1975). A propósito da análise automática do discurso: atualização e perspectivas (1975). In: GADET, F.; HAK, T. Por uma análise automática do discurso: uma introdução à obra de Michel Pêcheux. 3. ed. Trad. Bethânia S. Mariani et al. Campinas: Ed. da UNICAMP, 1997, p. 163-235. Tradução de: Towards an automatic discurse analysis.

(1983). O discurso: estrutura ou acontecimento. Trad. Eni P. Orlandi. 3. ed. Campinas: Pontes, 2002. Tradução de: Discourse: structure or event?

PERRENOUD, P. (1997). Construir as competências desde a escola. Trad. Bruno C. Magne. Porto Alegre: Artmed, 1999. Tradução de: Construire des compétences dès l'école.

(1999). Dez novas competências para ensinar. Trad. Patrícia C. Ramos. Porto Alegre: Artmed, 2000. Tradução de: Dix nouvelles compétences pour enseigner.

. et al. As competências para ensinar no século XXI: a formação dos professores e o

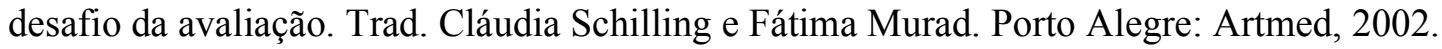

PETERS, M. Governamentalidade neoliberal e educação. In: SILVA, T. T. (Org.). O sujeito da educação: estudos foucaultianos. Trad. Tomaz T. da Silva. Petrópolis: Vozes, 1994, p. 211-224.

Modernismo e pós-modernismo. In: Pós-estruturalismo e filosofia da diferença: uma introdução. Trad. Tomaz T. da Silva. Belo Horizonte: Autêntica, 2000, p.12-19.

PLATERO, L. G. Is the book still on the table? Considerações sobre o ensino-aprendizagem de línguas estrangeiras no ensino médio: uma experiência pedagógica em língua inglesa. 2000. Dissertação (Mestrado em Educação) - Faculdade de Educação, Universidade de São Paulo, São Paulo, 2000.

PIGNATELLI, F. Que posso fazer? Foucault e a questão da liberdade e da agência docente. In: SILVA, T. T. (Org.). O sujeito da educação: estudos foucaultianos. Petrópolis: Vozes, 1994, p. 127-154. 
PIMENTA, S. G.; GHEDIN, E. (Org.). Professor reflexivo no Brasil: gênese e crítica de um conceito. São Paulo: Cortez, 2002.

POPKEWITZ, T. S. (1991). Reforma educacional: uma política sociológica - poder e conhecimento em educação. Trad. Beatriz A. Neves. Porto Alegre: Artes Médicas, 1997.

. História do currículo, regulação social e poder. In: SILVA, T. T. (Org.). O sujeito da educação: estudos foucaultianos. Trad. Tomaz T. da Silva. Petrópolis: Vozes, 1994, p. 173210.

. Struggling for the soul: the politics of schooling and the construction of the teacher. New York: Teachers College, 1998.

A social epistemology of educational research. In: ; FENDLER, L. (Ed.). Critical theories in education: changing terrains of knowledge and politics. New York: Routledge, 1999, p. 17-42.

. (1999). Reforma, conhecimento pedagógico e administração social da individualidade: a educação escolar como efeito do poder. In: IMBERNÓN, F. (Org). $A$ educação no século XXI: os desafios do futuro imediato. 2. ed. Trad. Ernani Rosa. Porto Alegre: Artmed, 2000, p. 141-169. Tradução de: La educación en el siglo XXI: los retos del futuro inmediato.

; LINDBLAD, S. Educational governance and social inclusion and exclusion: some conceptual difficulties and problematics in policy and research. Discourse: studies in the cultural politics of education, London, v. 21, n. 1, p. 5-44, Apr. 2000.

. Lutando em defesa da alma: a política do ensino e a construção do professor. Trad. Magda F. Lopes. Porto Alegre: Artmed, 2001. Tradução de: Struggling for the soul: the politics of schooling and the construction of the teacher.

. Hopes of progress and fears of the dangerous: research, cultural theses, and planning different human kinds. In: LADSON-BILLINGS, G; TATE, W. F. (Ed.). Education research in the public interest: social justice, action and policy. New York: Teachers College Press, 2006, p. 119-140.

PRETI, D. (Org.). Estudos de língua falada: variações e confrontos. 2. ed. São Paulo: Humanitas/FFLCH/USP, 1999. (Projetos paralelos, v. 3).

QUIRINO DE SOUSA, R. M. R. Professores de inglês da escola pública: investigações sobre suas identidades numa rede de conflitos. 2006. Dissertação (Mestrado em Letras) - Faculdade de Filosofia, Letras e Ciências Humanas, Universidade de São Paulo, São Paulo, 2006. Disponível em: <http://www.teses.usp.br/teses/disponiveis/8/8147/tde-01112006-155417>. Acesso em: 30 jan. 2008.

RODRIGUES, L. A. D. Dos fios, das tramas e dos nós: a tessitura da rede de crenças, pressupostos e conhecimento de professores de inglês que atuam no Ciclo I do Ensino Fundamental. 2005. Tese (Doutorado em Educação) - Faculdade de Educação, Universidade de São Paulo, São Paulo, 2005. 
RORTY, R. (1989). Contingência, ironia e solidariedade. Trad. Nuno F. da Fonseca. Lisboa: Editorial Presença, 1994. Tradução de: Contingency, irony and solidarity.

ROUANET, S. P. A verdade e a ilusão do pós-modernismo. In: . As razões do iluminismo. São Paulo: Cia. das Letras, 1989, p. 229-277.

SANT'ANNA, J. B. O discurso como prática social: representações e identidades de/sobre professores de literatura. 2007. Dissertação (Mestrado em Educação) - Faculdade de Educação, Universidade de São Paulo, São Paulo, 2007.

SANTOS, L. L. C. P. Formação de professores e saberes docentes. In: SHIGUNOV NETO, A.; MACIEL, L. S. B. (Org.). Reflexões sobre a formação de professores. Campinas: Papirus, 2002, p. 89-102. (Magistério: formação e trabalho pedagógico).

SCHÖN, D. A. (1998). Educando o profissional reflexivo: um novo design para o ensino e a aprendizagem. Trad. Roberto C. Costa. Porto Alegre: Artmed, 2000. Tradução de: Educating the reflective practioner: toward a new design for teaching and learning in the professions.

SECRETARIA DE EDUCAÇÃO BÁSICA. Linguagens, códigos e suas tecnologias. Brasília: Ministério da Educação, Secretaria de Educação Básica, 2006. (Orientações curriculares para o ensino médio, v. 1).

SEVERINO, A. J. A significação ideológica do processo pedagógico. In: . Educação, ideologia e contra-ideologia. São Paulo: EPU, 1986, p. 39-58. (Temas básicos de educação e ensino).

. Filosofia da educação: construindo a cidadania. São Paulo: FTD, 1994.

SILVA, T. T. (Org.). Teoria educacional crítica em tempos pós-modernos. Porto Alegre: Artes Médicas, 1993.

. (1999). O currículo como fetiche: a poética e a política do texto curricular. 2. ed. Belo Horizonte: Autêntica, 2001. Vozes, 2003.

(Org.). Identidade e diferença: a perspectiva dos estudos culturais. 2. ed. Petrópolis:

SKLIAR, C. Pedagogia (improvável) da diferença: e se o outro não estivesse aí? Trad. Giane Lessa. Rio de Janeiro: DP\&A, 2003. Tradução de: Y si el otro no estuviera ahí? Notas para una pedagogía (improbable) de la diferencia.

SOUZA, D. M. Identidade transversal e política de verdades: políticas curriculares e a construção da identidade do professor de línguas estrangeiras. In: CORACINI, M. J. (Org.). Identidade e discurso: (des)construindo subjetividades. Campinas: Ed. da UNICAMP; Chapecó: Argos Ed. Universitária, 2003, p. 337-350.

TAGATA, W. M. Reflective teaching na formação do professor de língua estrangeira: análise de uma experiência. 2000. Dissertação (Mestrado em Língua Inglesa e Literaturas Inglesa e Norte-Americana) - Faculdade de Filosofia, Letras e Ciências Humanas, Universidade de São Paulo, São Paulo, 2000. 
TEIXEIRA, M. A constituição heterogênea do sujeito discursivo: um exercício de análise em Partido alto de Chico Buarque. In: CORACINI, M. J.; PEREIRA, A. E. (Org.) Discurso e sociedade: práticas em análise do discurso. Pelotas: EDUCAT, 2001, p. 257-300.

THERRIEN, J. O saber do trabalho docente e a formação do professor. In: SHIGUNOV NETO, A.; MACIEL, L. S. B. (Org.). Reflexões sobre a formação de professores. Campinas: Papirus, 2002, p. 103-114. (Magistério: formação e trabalho pedagógico).

UNESCO (Brasil). O perfil dos professores brasileiros: o que fazem, o que pensam, o que almejam. São Paulo: Moderna, 2004.

U.S. DEPARTMENT OF EDUCATION. No Child Left Behind. Disponível em: $<$ http://answers.ed.gov/cgi-bin/education.cfg/php/enduser/std_adp.php?p_faqid=4>. Acesso em: 22 set. 2007.

USHER, R.; EDWARDS, R. Postmodernism and education. London: Routledge, 1994.

VAN ZANTEN, A. Education restructuring in France: middle-class parents and educational policy in metropolitan contexts. In: LINDBLAD, S.; POPKEWITZ, T. S. (Ed.). Educational restructuring: international perspectives on traveling policies. Greenwich, Connecticut: Information Age Publishing, 2004, p. 167-189.

WALLACE, M. J. Training foreign language teachers: a reflective approach. Cambridge: Cambridge University Press, 1991. (Cambridge teacher training and development).

WEINRICH, H. (1964). Estructura y función de los tiempos en el lenguaje. Trad. espanhola de Federico Latorre. Madrid: Ed. Gredos, 1974. Tradução de: Tempus. Besprochene und erzählte welt.

WIDDOWSON, H. G. Aspects of language teaching. Oxford: Oxford University Press, 1990.

ŽIŽEK, S. (1988). O basteamento ideológico: por que Lacan não é "pós-estruturalista"? In: O mais sublime dos histéricos: Hegel com Lacan. Trad. Vera Ribeiro. Rio de Janeiro: Jorge Zahar, 1991, p. 195-207. . (1994). O espectro da ideologia. In: Vera Ribeiro. Rio de Janeiro: Contraponto, 1996, p. 7-38. . (Org.). Um mapa da ideologia. Trad. 


\section{ANEXOS}

Anexo 1 - Diretrizes Curriculares Nacionais para a Formação de Professores da Educação Básica, em nível superior, curso de licenciatura, de graduação plena.

Anexo 2 - Diretrizes Curriculares para os cursos de Letras.

Anexo 3 - Transcrição das entrevistas com os professores e alunos - amostragem da Instituição 1.

Anexo 4 - Transcrição das entrevistas com os professores e alunos - amostragem da Instituição 2 


\section{Anexo 1}

\section{DIRETRIZES CURRICULARES NACIONAIS PARA A}

\section{FORMAÇÃO DE PROFESSORES DA EDUCAÇÃO BÁSICA, EM NÍVEL SUPERIOR, CURSO DE LICENCIATURA, DE GRADUAÇÃO PLENA}

O Presidente do Conselho Nacional de Educação, no uso de suas atribuições legais e tendo em vista o disposto no Art. $9^{\circ}, \S 2^{\circ}$, alínea "c" da Lei 4.024, de 20 de dezembro de 1961, com a redação dada pela Lei 9.131, de 25 de novembro de 1995, e com fundamento nos Pareceres CNE/CP 9/2001 e 27/2001, peças indispensáveis do conjunto das presentes Diretrizes Curriculares Nacionais, homologados pelo Senhor Ministro da Educação em 17 de janeiro de 2002, resolve:

Art. $1^{\circ}$ As Diretrizes Curriculares Nacionais para a Formação de Professores da Educação Básica, em nível superior, em curso de licenciatura, de graduação plena, constituem-se de um conjunto de princípios, fundamentos e procedimentos a serem observados na organização institucional e curricular de cada estabelecimento de ensino e aplicam-se a todas as etapas e modalidades da educação básica.

Art. $2^{\circ}$ A. organização curricular de cada instituição observará, além do disposto nos artigos 12 e 13 da Lei 9.394, de 20 de dezembro de 1996, outras formas de orientação inerentes à formação para a atividade docente, entre as quais o preparo para:

I - o ensino visando à aprendizagem do aluno;

II - o acolhimento e o trato da diversidade;

III - o exercício de atividades de enriquecimento cultural;

IV - o aprimoramento em práticas investigativas;

V - a elaboração e a execução de projetos de desenvolvimento dos conteúdos curriculares;

VI - o uso de tecnologias da informação e da comunicação e de metodologias, estratégias e materiais de apoio inovadores;

VII - o desenvolvimento de hábitos de colaboração e de trabalho em equipe.

Art. $3^{\circ}$ A formação de professores que atuarão nas diferentes etapas e modalidades da educação básica observará princípios norteadores desse preparo para o exercício profissional 
específico, que considerem:

I - a competência como concepção nuclear na orientação do curso;

II - a coerência entre a formação oferecida e a prática esperada do futuro professor, tendo em vista:

a) a simetria invertida, onde o preparo do professor, por ocorrer em lugar similar àquele em que vai atuar, demanda consistência entre o que faz na formação e o que dele se espera;

b) a aprendizagem como processo de construção de conhecimentos, habilidades e valores em interação com a realidade e com os demais indivíduos, no qual são colocadas em uso capacidades pessoais;

c) os conteúdos, como meio e suporte para a constituição das competências;

d) a avaliação como parte integrante do processo de formação, que possibilita o diagnóstico de lacunas e a aferição dos resultados alcançados, consideradas as competências a serem constituídas e a identificação das mudanças de percurso eventualmente necessárias.

III - a pesquisa, com foco no processo de ensino e de aprendizagem, uma vez que ensinar requer, tanto dispor de conhecimentos e mobilizá-los para a ação, como compreender o processo de construção do conhecimento.

Art. $4^{\circ} \mathrm{Na}$ concepção, no desenvolvimento e na abrangência dos cursos de formação é fundamental que se busque:

I - considerar o conjunto das competências necessárias à atuação profissional;

II - adotar essas competências como norteadoras, tanto da proposta pedagógica, em especial do currículo e da avaliação, quanto da organização institucional e da gestão da escola de formação.

Art. $5^{\circ} \mathrm{O}$ projeto pedagógico de cada curso, considerado o artigo anterior, levará em conta que:

I - a formação deverá garantir a constituição das competências objetivadas na educação básica;

II - o desenvolvimento das competências exige que a formação contemple diferentes âmbitos do conhecimento profissional do professor;

III - a seleção dos conteúdos das áreas de ensino da educação básica deve orientar-se por ir além daquilo que os professores irão ensinar nas diferentes etapas da escolaridade; 
IV - os conteúdos a serem ensinados na escolaridade básica devem ser tratados de modo articulado com suas didáticas específicas;

$\mathrm{V}$ - a avaliação deve ter como finalidade a orientação do trabalho dos formadores, a autonomia dos futuros professores em relação ao seu processo de aprendizagem e a qualificação dos profissionais com condições de iniciar a carreira."

Parágrafo único. A aprendizagem deverá ser orientada pelo princípio metodológico geral, que pode ser traduzido pela ação-reflexão-ação e que aponta a resolução de situações-problema como uma das estratégias didáticas privilegiadas.

Art. $6^{\circ} \mathrm{Na}$ construção do projeto pedagógico dos cursos de formação dos docentes, serão consideradas:

I - as competências referentes ao comprometimento com os valores inspiradores da sociedade democrática;

II - as competências referentes à compreensão do papel social da escola;

III - as competências referentes ao domínio dos conteúdos a seres socializados, aos seus significados em diferentes contextos e sua articulação interdisciplinar;

IV - as competências referentes ao domínio do conhecimento pedagógico;

$\mathrm{V}$ - as competências referentes ao conhecimento de processos de investigação que possibilitem o aperfeiçoamento da prática pedagógica;

VI - as competências referentes ao gerenciamento do próprio desenvolvimento profissional.

$\S 1^{\circ} \mathrm{O}$ conjunto das competências enumeradas neste artigo não esgota tudo que uma escola de formação possa oferecer aos seus alunos, mas pontua demandas importantes oriundas da análise da atuação profissional e assenta-se na legislação vigente e nas diretrizes curriculares nacionais para a educação básica.

$\S 2^{\circ}$ As referidas competências deverão ser contextualizadas e complementadas pelas competências específicas próprias de cada etapa e modalidade da educação básica e de cada área do conhecimento a ser contemplada na formação.

$\S 3^{\circ}$ A definição dos conhecimentos exigidos para a constituição de competências deverá além da formação específica relacionada às diferentes etapas da educação básica, propiciar a inserção no debate contemporâneo mais amplo, envolvendo questões culturais, sociais, econômicas e o conhecimento sobre o desenvolvimento humano e a própria docência, contemplando:

I - cultura geral e profissional; 
II - conhecimento sobre crianças, adolescentes, jovens e adultos, aí incluídas as especificidades dos alunos com necessidades educacionais especiais $\mathrm{e}$ as das comunidades indígenas;

III - conhecimento sobre dimensão cultural, social, política e econômica da educação;

IV - conteúdos das áreas de conhecimento que serão objeto de ensino;

$\mathrm{V}$ - conhecimento pedagógico;

VI - conhecimento advindo da experiência.

Art. $7^{\circ}$ A organização institucional da formação dos professores, a serviço do desenvolvimento de competências, levará em conta que:

I - a formação deverá ser realizada em processo autônomo, em curso de licenciatura plena, numa estrutura com identidade própria;

II - será mantida, quando couber, estreita articulação com institutos, departamentos e cursos de áreas específicas;

III - as instituições constituirão direção e colegiados próprios, que formulem seus próprios projetos pedagógicos, articulem as unidades acadêmicas envolvidas e, a partir do projeto, tomem as decisões sobre organização institucional e sobre as questões administrativas no âmbito de suas competências;

IV - as instituições de formação trabalharão em interação sistemática com as escolas de educação básica, desenvolvendo projetos de formação compartilhados;

V - a organização institucional preverá a formação dos formadores, incluindo na sua jornada de trabalho tempo e espaço para as atividades coletivas dos docentes do curso, estudos e investigações sobre as questões referentes ao aprendizado dos professores em formação;

VI - as escolas de formação garantirão, com qualidade e quantidade, recursos pedagógicos como biblioteca, laboratórios, videoteca, entre outros, além de recursos de tecnologias da informação e da comunicação;

VII - serão adotadas iniciativas que garantam parcerias para a promoção de atividades culturais destinadas aos formadores e futuros professores;

VIII - nas instituições de ensino superior não detentoras de autonomia universitária serão criados Institutos Superiores de Educação, para congregar os cursos de formação de professores que ofereçam licenciaturas em curso Normal Superior para docência multidisciplinar na educação infantil e anos iniciais do ensino fundamental ou licenciaturas para docência nas etapas subseqüentes da educação básica. 
Art. $8^{\circ}$ As competências profissionais a serem constituídas pelos professores em formação, de acordo com as presentes Diretrizes, devem ser a referência para todas as formas de avaliação dos cursos, sendo estas:

I - periódicas e sistemáticas, com procedimentos e processos diversificados, incluindo conteúdos trabalhados, modelo de organização, desempenho do quadro de formadores e qualidade da vinculação com escolas de educação infantil, ensino fundamental e ensino médio, conforme o caso;

II - feitas por procedimentos internos e externos, que permitam a identificação das diferentes dimensões daquilo que for avaliado;

III - incidentes sobre processos e resultados.

Art. $9^{\circ}$ A autorização de funcionamento e o reconhecimento de cursos de formação e o credenciamento da instituição decorrerão de avaliação externa no locus institucional, por corpo de especialistas direta ou indiretamente ligados à formação ou ao exercício profissional de professores para a educação básica, tomando como referência as competências profissionais de que trata esta Resolução e as normas aplicáveis à matéria.

Art. $10^{\circ}$ A seleção e o ordenamento dos conteúdos dos diferentes âmbitos de conhecimento que comporão a matriz curricular para a formação de professores, de que trata esta Resolução, serão de competência da instituição de ensino, sendo o seu planejamento o primeiro passo para a transposição didática, que visa a transformar os conteúdos selecionados em objeto de ensino dos futuros professores.

Art. $11^{\circ}$ Os critérios de organização da matriz curricular, bem como a alocação de tempos e espaços curriculares se expressam em eixos em torno dos quais se articulam dimensões a serem contempladas, na forma a seguir indicada:

I - eixo articulador dos diferentes âmbitos de conhecimento profissional;

II - eixo articulador da interação e da comunicação, bem como do desenvolvimento da autonomia intelectual e profissional;

III - eixo articulador entre disciplinaridade e interdisciplinaridade;

IV - eixo articulador da formação comum com a formação específica;

V - eixo articulador dos conhecimentos a serem ensinados e dos conhecimentos filosóficos, educacionais e pedagógicos que fundamentam a ação educativa; 
VI - eixo articulador das dimensões teóricas e práticas.

Parágrafo único. Nas licenciaturas em educação infantil e anos iniciais do ensino fundamental deverão preponderar os tempos dedicados à constituição de conhecimento sobre os objetos de ensino e nas demais licenciaturas o tempo dedicado às dimensões pedagógicas não será inferior à quinta parte da carga horária total.

Art. $12^{\circ}$ Os cursos de formação de professores em nível superior terão a sua duração definida pelo Conselho Pleno, em parecer e resolução específica sobre sua carga horária.

$\S 1^{\circ}$ A prática, na matriz curricular, não poderá ficar reduzida a um espaço isolado, que a restrinja ao estágio, desarticulado do restante do curso.

$\S 2^{\circ}$ A prática deverá estar presente desde o início do curso e permear toda a formação do professor.

$\S 3^{\circ}$ No interior das áreas ou das disciplinas que constituírem os componentes curriculares de formação, e não apenas nas disciplinas pedagógicas, todas terão a sua dimensão prática.

Art. $13^{\circ}$ Em tempo e espaço curricular específico, a coordenação da dimensão prática transcenderá o estágio e terá como finalidade promover a articulação das diferentes práticas, numa perspectiva interdisciplinar.

$\S 1^{\circ}$ A prática será desenvolvida com ênfase nos procedimentos de observação e reflexão, visando à atuação em situações contextualizadas, com o registro dessas observações realizadas e a resolução de situações-problema.

$\S 2^{\circ}$ A presença da prática profissional na formação do professor, que não prescinde da observação e ação direta, poderá ser enriquecida com tecnologias da informação, incluídos o computador e o vídeo, narrativas orais e escritas de professores, produções de alunos, situações simuladoras e estudo de casos.

$\S 3^{\circ} \mathrm{O}$ estágio curricular supervisionado, definido por lei, a ser realizado em escola de educação básica, e respeitado o regime de colaboração entre os sistemas de ensino, deve ser desenvolvido a partir do início da segunda metade do curso e ser avaliado conjuntamente pela escola formadora e a escola campo de estágio.

Art. $14^{\circ}$ Nestas Diretrizes, é enfatizada a flexibilidade necessária, de modo que cada instituição formadora construa projetos inovadores e próprios, integrando os eixos articuladores nelas mencionados. 
$\S 1^{\circ}$ A flexibilidade abrangerá as dimensões teóricas e práticas, de interdisciplinaridade, dos conhecimentos a serem ensinados, dos que fundamentam a ação pedagógica, da formação comum e específica, bem como dos diferentes âmbitos do conhecimento e da autonomia intelectual e profissional.

$\S 2^{\circ} \mathrm{Na}$ definição da estrutura institucional e curricular do curso, caberá a concepção de um sistema de oferta de formação continuada, que propicie oportunidade de retorno planejado e sistemático dos professores às agências formadoras.

Art. $15^{\circ}$ Os cursos de formação de professores para a educação básica que se encontrarem em funcionamento deverão se adaptar a esta Resolução, no prazo de dois anos.

$\S 1^{\circ}$ Nenhum novo curso será autorizado, a partir da vigência destas normas, sem que o seu projeto seja organizado nos termos das mesmas.

$\S 2^{\circ}$ Os projetos em tramitação deverão ser restituídos aos requerentes para a devida adequação.

Art. $16^{\circ} \mathrm{O}$ Ministério da Educação, em conformidade com $\S 1^{\circ}$ Art. 8 da Lei 9.394, coordenará e articulará em regime de colaboração com o Conselho Nacional de Educação, o Conselho Nacional de Secretários Estaduais de Educação, o Fórum Nacional de Conselhos Estaduais de Educação, a União Nacional dos Dirigentes Municipais de Educação e representantes de Conselhos Municipais de Educação e das associações profissionais e científicas, a formulação de proposta de diretrizes para a organização de um sistema federativo de certificação de competência dos professores de educação básica.

Art. $17^{\circ}$ As dúvidas eventualmente surgidas, quanto a estas disposições, serão dirimidas pelo Conselho Nacional de Educação, nos termos do Art. 90 da Lei 9.394.

Art. $18^{\circ} \mathrm{O}$ parecer e a resolução referentes à carga horária, previstos no Artigo 12 desta resolução, serão elaborados por comissão bicameral, a qual terá cinqüenta dias de prazo para submeter suas propostas ao Conselho Pleno.

Art. $19^{\circ}$ Esta Resolução entra em vigor na data de sua publicação, revogadas as disposições em contrário. 


\section{Anexo 2}

\section{DIRETRIZES CURRICULARES PARA OS CURSOS DE LETRAS}

\section{Introdução}

Esta proposta de Diretrizes Curriculares leva em consideração os desafios da educação superior diante das intensas transformações que têm ocorrido na sociedade contemporânea, no mercado de trabalho e nas condições de exercício profissional. Concebe-se a Universidade não apenas como produtora e detentora do conhecimento e do saber, mas, também, como instância voltada para atender às necessidades educativas e tecnológicas da sociedade. Ressalta-se, no entanto, que a Universidade não pode ser vista apenas como instância reflexa da sociedade e do mundo do trabalho. Ela deve ser um espaço de cultura e de imaginação criativa, capaz de intervir na sociedade, transformando-a em termos éticos

A área de Letras, abrigada nas ciências humanas, põe em relevo a relação dialética entre o pragmatismo da sociedade moderna e o cultivo dos valores humanistas.

Decorre daí que os cursos de graduação em Letras deverão ter estruturas flexíveis que:

- facultem ao profissional a ser formado opções de conhecimento e de atuação no mercado de trabalho;

- criem oportunidade para o desenvolvimento de habilidades necessárias para se atingir a competência desejada no desempenho profissional;

- dêem prioridade à abordagem pedagógica centrada no desenvolvimento da autonomia do aluno;

- promovam articulação constante entre ensino, pesquisa e extensão, além de articulação direta com a pós-graduação;

- propiciem o exercício da autonomia universitária, ficando a cargo da Instituição de Ensino Superior definições como perfil profissional, carga horária, atividades curriculares básicas, complementares e de estágio.

Portanto, é necessário que se amplie o conceito de currículo, que deve ser concebido como construção cultural que propicie a aquisição do saber de forma articulada. Por sua 
natureza teórico-prática, essencialmente orgânica, o currículo deve ser constituído tanto pelo conjunto de conhecimentos, competências a habilidades, como pelos objetivos que busca alcançar. Assim, define-se currículo como todo e qualquer conjunto de atividades acadêmicas que integralizam um curso. Essa definição introduz o conceito de atividade acadêmica curricular - aquela considerada relevante para que o estudante adquira competências a habilidades necessárias a sua formação e que possa ser avaliada interna e externamente como processo continuo e transformador, conceito que não exclui as disciplinas convencionais.

Os princípios que norteiam esta proposta de Diretrizes Curriculares são a flexibilidade na organização do curso de Letras e a consciência da diversidade / heterogeneidade do conhecimento do aluno, tanto no que se refere à sua formação anterior, quanto aos interesses e expectativas em relação ao curso a ao futuro exercício da profissão.

A flexibilização curricular, para responder às novas demandas sociais a aos princípios expostos, é entendida como a possibilidade de:

- eliminar a rigidez estrutural do curso;

- imprimir ritmo e duração ao curso, nos limites adiante estabelecidos;

- utilizar, de modo mais eficiente, os recursos de formação já existentes nas instituições de ensino superior.

A flexibilização do currículo, na qual se prevê nova validação de atividades acadêmicas, requer o desdobramento do papel de professor na figura de orientador, que deverá responder não só pelo ensino de conteúdos programáticos, mas também pela qualidade da formação do aluno. Da mesma forma, o colegiado de graduação do curso de Letras é a instância competente para a concepção e o acompanhamento da diversidade curricular que a IES implantará.

\section{Diretrizes Curriculares}

\section{Perfil dos Formandos}


O objetivo do Curso de Letras é formar profissionais interculturalmente competentes, capazes de lidar, de forma crítica, com as linguagens, especialmente a verbal, nos contextos oral e escrito, e conscientes de sua inserção na sociedade e das relações com o outro.

Independentemente da modalidade escolhida, o profissional em Letras deve ter domínio do uso da língua ou das línguas que sejam objeto de seus estudos, em termos de sua estrutura, funcionamento e manifestações culturais, além de ter consciência das variedades lingüísticas e culturais. Deve ser capaz de refletir teoricamente sobre a linguagem, de fazer uso de novas tecnologias e de compreender sua formação profissional como processo contínuo, autônomo e permanente. A pesquisa e a extensão, além do ensino, devem articular-se neste processo. $\mathrm{O}$ profissional deve, ainda, ter capacidade de reflexão crítica sobre temas e questões relativas aos conhecimentos lingüísticos e literários.

\section{Competências e Habilidades}

O graduado em Letras, tanto em língua materna quanto em língua estrangeira clássica ou moderna, nas modalidades de bacharelado e de licenciatura, deverá ser identificado por múltiplas competências e habilidades adquiridas durante sua formação acadêmica convencional, teórica e prática, ou fora dela.

Nesse sentido, visando à formação de profissionais que demandem o domínio da língua estudada e suas culturas para atuar como professores, pesquisadores, críticos literários, tradutores, intérpretes, revisores de textos, roteiristas, secretários, assessores culturais, entre outras atividades, o curso de Letras deve contribuir para o desenvolvimento das seguintes competências a habilidades:

- domínio do uso da língua portuguesa ou de uma língua estrangeira, nas suas manifestações oral e escrita, em termos de recepção e produção de textos;

- reflexão analítica e crítica sobre a linguagem como fenômeno psicológico, educacional, social, histórico, cultural, político e ideológico;

- visão crítica das perspectivas teóricas adotadas nas investigações lingüísticas e literárias, que fundamentam sua formação profissional;

- preparação profissional atualizada, de acordo com a dinâmica do mercado de trabalho;

- percepção de diferentes contextos interculturais;

- utilização dos recursos da informática; 
- domínio dos conteúdos básicos que são objeto dos processos de ensino e aprendizagem no ensino fundamental e médio;

- domínio dos métodos e técnicas pedagógicas que permitam a transposição dos conhecimentos para os diferentes níveis de ensino.

O resultado do processo de aprendizagem deverá ser a formação de profissional que, além da base específica consolidada, esteja apto a atuar, interdisciplinarmente, em áreas afins. Deverá ter, também, a capacidade de resolver problemas, tomar decisões, trabalhar em equipe e comunicar-se dentro da multidisciplinaridade dos diversos saberes que compõem a formação universitária em Letras. O profissional de Letras deverá, ainda, estar compromissado com a ética, com a responsabilidade social e educacional, e com as conseqüências de sua atuação no mundo do trabalho. Finalmente, deverá ampliar o senso crítico necessário para compreender a importância da busca permanente da educação continuada e do desenvolvimento profissional.

\section{Conteúdos Curriculares}

Considerando os diversos profissionais que o curso de Letras pode formar, os conteúdos caracterizadores básicos devem estar ligados à área dos Estudos Lingüísticos e Literários, contemplando o desenvolvimento de competências a habilidades específicas. Os estudos lingüísticos e literários devem fundar-se na percepção da língua e da literatura como prática social e como forma mais elaborada das manifestações culturais. Devem articular a reflexão teórico-crítica com os domínios da prática - essenciais aos profissionais de Letras, de modo a dar prioridade à abordagem intercultural, que concebe a diferença como valor antropológico e como forma de desenvolver o espírito crítico frente à realidade.

De forma integrada aos conteúdos caracterizadores básicos do curso de Letras, devem estar os conteúdos caracterizadores de formação profissional em Letras. Estes devem ser entendidos como toda e qualquer atividade acadêmica que constitua o processo de aquisição de competências e habilidades necessárias ao exercício da profissão, e incluem os estudos lingüísticos e literários, práticas profissionalizantes, estudos complementares, estágios,

seminários, congressos, projetos de pesquisa, de extensão e de docência, cursos seqüenciais, de acordo com as diferentes propostas dos colegiados das IES e cursadas pelos estudantes. 
No caso das licenciaturas deverão ser incluídos os conteúdos definidos para a educação básica, as didáticas próprias de cada conteúdo a as pesquisas que as embasam.

O processo articulatório entre habilidades e competências no curso de Letras pressupõe o desenvolvimento de atividades de caráter prático durante o período de integralização do curso.

\section{Estruturação do Curso}

Os cursos devem incluir no seu projeto pedagógico os critérios para o estabelecimento das disciplinas obrigatórias e optativas das atividades acadêmicas do bacharelado e da licenciatura, e a sua forma de organização: modular, por crédito ou seriado.

Os cursos de licenciatura deverão ser orientados também pelas Diretrizes para a Formação Inicial de Professores da Educação Básica em cursos de nível superior.

\section{Avaliação}

A avaliação a ser implementada pelo colegiado do curso de Letras deve constituir processo de aperfeiçoamento contínuo e de crescimento qualitativo, devendo pautar-se:

- pela coerência das atividades quanto à concepção e aos objetivos do projeto pedagógico e quanto ao perfil do profissional formado pelo curso de Letras;

- pela validação das atividades acadêmicas por colegiados competentes;

- pela orientação acadêmica individualizada;

- pela adoção de instrumentos variados de avaliação interna;

- pela disposição permanente de participar de avaliação externa. 


\section{Anexo 3}

\section{TRANSCRIÇÃO DAS ENTREVISTAS COM OS PROFESSORES E ALUNOS - AMOSTRAGEM DA INSTITUIÇÃO 1}

\section{Professor 3 - P3}

Pergunta 1

eu me sinto assim com uma responsabilidade muito grande até muito maior do que... quando são professores de conteúdo de uma determinada disciplina... porque afinal de contas... eu to formando alguém que vai passar pra frente... essa formação... essa experiência... e eu dou aula de prática de ensino... e::: aí eu sinto uma responsabilidade grande... principalmente pelo seguinte... éh os alunos eu acho... que eles acabam reproduzindo bastante... a experiência que eles têm... em sala de aula como alunos... então o professor fica um pouco como um espelho... e::: ... eles... de certa maneira... vão tentar reproduzir... o que ele acha que é positivo... do professor que eles tiveram pros seus futuros alunos... eu tenho ouvido alunos falar comigo... por exemplo... "ah eu gostei dessa sua aula... quando eu der aula eu quero fazer assim... eu quero usar esse material... quero usar esse método..." então eu acho que é a nossa responsabilidade é grande por isso... a gente acaba sendo modelo... acaba sendo um exemplo... éh... basicamente... isso...

\section{Pergunta 2}

eu procuro enfatizar... quando eu penso em formação de professor... eu procuro enfatizar bastante a questão prática... embora eu não dispense a teoria... então eu trabalho com textos teóricos que falam... sobre o professor... a relação com o aluno... as teorias... principalmente... as mais recentes da pedagogia... o... a... o que defende a idéia de que o aluno deve... ter uma liberdade e uma autonomia pra buscar o conhecimento... o professor acaba sendo um canal de de::: éh veiculação desse conhecimento... mas ele não é a autoridade que tem... todo o saber... que detém esse saber... então eu trabalho um pouco com a teoria pra mostrar para os alunos que... é possível sair daquele esquema tradicional... e que a relação professor-aluno é uma relação de::: de mão única... não é?... em que o professor é detentor do conteúdo e passa isso pro aluno... então... as teorias mais recentes... com as quais eu tenho trabalhado em sala de aula elas demonstram que não é esse o melhor caminho... é preciso abrir... é preciso 
expandir... é preciso se aproximar do aluno... e incorporar a experiência dele também na prática docente... agora isso é só teoria o que eu procuro fazer mesmo... é em sala de aula... é exercitar a::. ... fazer com que o aluno exercite a docência... fazer com que cada aluno se responsabilize por um tema... com que o aluno apresente esse tema pros colegas... fazer com que o aluno prepare as suas aulas e depois éh... exponha isso pra sala... ou por meio de seminários ou por meio de aula mesmo que o aluno fica responsável... então eu procuro enfatizar bastante essa prática... até pra que os alunos possam sentir como que é::: ... na realidade... uma aula... eu sei que eles têm por exemplo... estágio... que é um estágio de observação e que eles já têm experiência nesse sentido... mas eu acho importante eles mesmos serem responsáveis por todo o processo... preparação de aula... apresentação... dessa aula... pela... na verdade... pelo contato com a sala de aula... e aluno fica muito nervoso quando ele tem que expor... a sua maneira de apresentar um conteúdo... então... acho que é uma forma de exercitar isso... eu procuro enfatizar esse aspecto...

\section{Pergunta 3}

bom... eu vejo o aluno um pouco perdido... na verdade... primeiro... porque ele tem muita dificuldade em relação a conteúdos... então eles... até têm consciência por exemplo que um curso de três anos... como é atualmente na maior parte das faculdades... é um curso que não supre todas as suas necessidades... então o aluno vem falar... "olha... eu tenho falhas nesse conteúdo... eu não vi isso... eu não li essa obra... eu não vi esse período..." seja lá o que for... esse tema... então eles têm dificuldade de conteúdo... ah... isso já é alguma coisa que os incomoda um pouco... ah... agora do ponto de vista prático... as experiências que os alunos têm... eles contam... por exemplo... quando eles fazem estágio... ou então quando eles têm que preparar uma aula e expor... eu os vejo também um pouco perdidos... porque... talvez não só perdidos... desanimados também... porque eles escutam as... os testemunhos dos colegas... dos outros professores... e esses testemunhos em geral são em relação à escola pública... e a gente sabe que a escola pública passa por uma fase bastante crítica... então eles ficam um pouco desnorteados... alguns ainda não têm aquele ideal que é... "eu quero trabalhar... eu quero ser professor... eu quero ir para a escola pública... eu quero tentar mudar a situação...” mas muitos deles... algo que há alguns anos atrás eu não escutava de aluno... muitos deles vêm dizer que... eh não têm interesse em ser professor porque a profissão não é valorizada... porque... o que eles presenciam... testemunham... o que eles escutam é alguma coisa absolutamente... desabonadora da docência... então... éh... eu vejo o aluno... como... alguém um pouco perdido nessa atual situação... nessa atual conjuntura... mas vejo também aspectos positivos... o 
aluno... éh em geral... quando ele não desiste totalmente... e são poucos os que assumem... a desistência e falam "ah eu não vou mais dar aula... eu não quero... eu vou mudar de profissão... eu vou buscar outra coisa...” eles ainda guardam um ideal... eles têm consciência do problema... eles sabem mais ou menos quais são os caminhos que devem ser seguidos pra solucionar os problemas... quer dizer... "nós não podemos manter esse tipo de ensino... precisamos incentivar o aluno a fazer essa atividade... precisamos mudar o material didático... precisamos atuar de forma diferente...” tem consciência e alguns têm vontade de fazer isso... vários também vêm me relatar que... por exemplo... uma experiência de estágio... uma experiência... como professor eventual... que alguns já são... eles me dizem que fizeram determinada atividade e que foi altamente positivo... que a sala deu uma resposta... bastante positiva... gostaram deles... querem que eles voltem... então têm alguns alunos que... ainda mantém uma disposição pra mudança... pra levar adiante a profissão docente... agora se eu fosse pesar tudo na balança... eu diria que há muito mais... que há muito mais... éh... aspectos negativos... não é?... os alunos estão muito mais preocupados... muito mais perdidos... muito mais... até desinteressados do que os aspectos positivos... essa é a impressão que eu tenho... num contato assim até um pouco impressionista com o aluno... não é nada muito científico... mas é a impressão que acaba sobrando dessa relação com os alunos... 


\section{Aluno 1 - A1}

Pergunta 1

bom éh... eu me vejo assim... em cima da ((citou instituição um)) assim que eu tive... ah... eu não sei se::: vai me ajudar na prática... acho que na parte de literatura... portuguesa e brasileira... vai fazer diferença... agora na parte de inglês eu acho que não::: não foi legal... eu já sou formada pelo ((citou instituto de idiomas))... e o que eu vi aqui não foi nada diferente do que eu já tinha visto... a não ser alguma coisa de literatura... porque a gente acaba não vendo tanto mas... a questão de português eu senti defasagem... no ensino de língua portuguesa... é assim... éh... realmente eu não sei se porque eu sou muito nova também... eu to saindo assim ainda meio insegura do curso... eu acho que eu to bem preparada na parte de inglês... mas não pelo curso da ((citou instituição um)) pelo curso que eu já tive... então acho que não fez diferença... agora aquilo que eu já te falei na questão de literatura... brasileira e portuguesa eu já me sinto segura...

\section{Pergunta 2}

bom primeiro eu acho que deve ter prática... não só aqui dentro... acho que devem existir ( ) dicas de... sei lá... de atividades que falem da situação... que você ta na sala de aula... prática fora também acho que o estágio podia ser voltado pra isso... as horas podiam ser diminuídas e::: a gente poder ter uma prática mesmo em cima... acompanhamento melhor...

Professor-pesquisador: na aula de prática isso não aconteceu?

não... não::: é tudo teoria... na prática de ensino a gente só vê teoria... e sinceramente... eu particularmente não gosto... desses teóricos... eu vejo assim como uma coisa quase que utópica eles falando das teorias... eu não acho que isso possa ser aplicado... então/mesmo/na aula que seria de prática (tanto)... pedagógica como de português ou inglês... a gente só lê o texto e::: ... poucas discussões... até prática de ensino de português a gente teve um pouco mais mas... mesmo assim eu acho que podia ter sido muito melhor... podia ter sido realmente PRÁTICA fazer juz ao nome... mas a gente só leu teoria... e isso acho que faz falta... (pra aqui) a ((citou instituição um)) ta formando... é um curso de licenciatura então... você tem que visar isso... até a própria matéria de psicologia... éh... psicologia não foi voltada pra psicologia da educação... de forma alguma... acho que podia ter sido bem melhor essa parte também... eu senti assim um curso muito teórico... e eu particularmente... não gosto... 


\section{Pergunta 3}

é... eu tive impressão assim de... ter... sei lá meia dúzia de professores muito bem formados e informados... saberem passar mesmo todo o conteúdo que eu acho que esse é o grande problema você ter conhecimento e não saber transmitir... então eu acho que da para contar uma meia dúzia... aqui... que realmente faz um trabalho legal se preocupa... que realmente ta dentro da proposta de licenciatura... do curso tal... agora a grande maioria eu vejo com... ((pausa)) assim a formação em defasagem... eu vejo defasagem na formação... ((pausa)) eu vejo como pessoas que tão aqui... só... sei lá... até sendo bem realista pra ganhar dinheiro mesmo não tão nem aí com a gente... não tão nem ai com a formação que eles estão dando... e mesmo com um modelo de aula do tipo você senta... lê um slide... a aula inteira... poxa ((exclamou)) se for pra eu ler um slide eu leio na minha casa eu sei ler... a pessoa não explica... a pessoa... lê o que ta ali... e não acrescenta nada... então eu acho que a maioria dos professores que eu tive aqui... foram pra esse lado... mas porém eu acho que o que vai ficar marcado pra mim são os professores realmente bons que eu tive... porque os bons são realmente bons... e realmente vão fazer diferença pela (ação)... mas eu acho que... pelo que eu converso... isso não é só aqui da ((citou instituição um))... eu acho que... pelo que eu converso tem cursos... piores... e a gente já tem esse estereótipo... os próprios alunos de letras ahn... a gente já tem esse... a gente criou mesmo esse estereótipo de "ah não o curso de letras não é legal aqui..." mas se você for comparar... éh... é muito melhor do que muitos lugares... é um... tem alguns professores que tem uma visão mais... ehn... eu não sei mais moderna não é aquela coisa... antiga tal... (isso além da)... eles te ensinam a analisar etc que eu acho que é isso que vale... eles... te ensinarem te darem dicas pra você:.: ... poder fazer uma análise e tal... porque... dar um livro pra ler... e destacar características qualquer um faz o problema é uma análise... éh... é ta puxando isso no aluno... é fazer o aluno ir pesquisar... então esses bons professores que conseguiram isso vão ficar marcados apesar/apesar de serem muito poucos assim acho que dá pra contar assim na mão... numa mão só... 


\section{Anexo 4}

\section{TRANSCRIÇÃO DAS ENTREVISTAS COM OS PROFESSORES E ALUNOS - AMOSTRAGEM DA INSTITUIÇÃO 2}

\section{Professor 4 - P4}

Pergunta 1

bom... eu... eu me realizo muito na licenciatura né... eu dou aula na licenciatura desde que entrei aqui na ((citou instituição dois))... portanto há nove anos... e:.: aqui a gente... se reveza né... um semestre a gente está na licenciatura... outro no curso de graduação da pedagogia... e outro... na::: pós-graduação... nem sempre com essa regularidade... mas.... não existe professores exclusivos da pós... da graduação... para não ter essa hierarquia né... além de nós nos rodiziarmos nos diferentes cursos... nós fazemos pesquisa... e trabalhamos na extensão né... então o trabalho de docência é uma das partes da nossa tarefa né... eu particularmente gosto muito de lecionar... é o que eu sei fazer... enfim trabalho com isso há muitos anos... antes de ser professora da ((citou instituição dois)) fui da ((citou outra universidade)) também... e tal... e a atividade acadêmica de um modo geral me realiza muito... mas ser professora da licenciatura em particular... é algo que me dá muito prazer... né... por várias razões... primeiro porque::: eu acho que é um desafio enorme né... agora mesmo... daqui a pouco eu vou entrar em aula ((falou rindo))... tenho quase setenta e cinco alunos... né... classes cheias e mais do que isso há uma diversidade muito grande... do ponto de vista dos cursos de origem... das expectativas né... das trajetórias pessoais... então o que eles têm em comum é o fato de serem estudante da ((citou instituição dois)) e estarem em um curso que (em tese) irá prepará-los para a docência... mas há uma diversidade brutal mesmo né... em termos de formação e::: e também expectativas para a educação... alguns já lecionam... outros tiveram alguma experiência... ainda muito::. pequena na área... da prática... escolar né... alguns não querem ser professor... então... eu acho que isso:.: é uma coisa... que me incomoda e acho que é uma coisa muito contemporânea... estão na licenciatura um pouco por prevenção... se não conseguir emprego... uma coisa assim meio... complicada né... uma relação que (acho que) tem mais a ver com falta de perspectiva profissional do que vontade mesmo de ser professor né... e outros querem mesmo ser professor e estão dispostos a::: ter uma formação mais adequada ( ) mas então lidar com essa diversidade é um desafio enorme... 
e::: fazê-los éhn... num certo estágio do curso falar a mesma língua... falar dessa temática... que o meu campo é psicologia da educação né... no começo é um pouco difícil... mas da metade em diante é muito interessante porque na verdade... eu tenho a favor o fato de lidar com a temática do humano né... da complexidade do desenvolvimento psicológico e tal... que é um tema ainda que hermético mas altamente atraente... as pessoas se entusiasmam pelo assunto né... querem saber mais sobre os processos psicológicos... como é que a criança aprende... se desenvolve e tal... então ahn... ao mesmo tempo que é um desafío... eles... conseguirem... lidar com um texto às vezes um pouco mais complexo... (ou) textos que não têm utilidade... autores que eles nunca ouviram falar né... é muito prazeroso porque eu vejo o grupo se envolver... e se interessar né... eu particularmente gosto muito de ser professora da licenciatura... acho muito legal...

\section{Pergunta 2}

eu tomo alguns cuidados assim... eu na verdade persigo::: eu busco uma coerência entre aquilo que eu apregôo... em termos de prática educativa e aquilo que eu faço como professora né... eu acho que... especialmente aqui na faculdade de educação nós somos modelos... não adianta::: eu gastar duas aulas falando dos malefícios de uma aula expositiva por meio::: de uma aula expositiva né... eu acho que essas contradições esses paradoxos ainda que muito presentes nos cursos de licenciatura... cursos de formação de professor né... de um modo geral... eles são muito perversos né... e::: são alunos que quase sempre via de regra vieram de formaç/programas de formação mais conservadores... né... então quando a gente fala da renovação da escola... de buscar uma pedagogia mais interessada... mais... que leve o aluno a ser um sujeito mais ativo mais crítico tal... muitas vezes a gente está falando::: grego porque::: esses alunos não passaram por esse tipo de escolarização... né... e::: eu acho que as nossas práticas elas têm que ser reveladoras... e exemplares daquilo que a gente defende né... então como fazer isso? ... bom... desde a escolha da temática... da organização das aulas... o planejamento das aulas... eu planejo as aulas né... acho que... por mais/eu já dei aulas por muitos anos... eu acho que é um respeito aos alunos... planejar cada aula como um momento muito especial mesmo... como um momento único... né... que eles viverão e eu também vou viver né... éh... mas procuro::: tornar as aulas mais dinâmicas possíveis... levo bastante recursos... trabalho muito com filmografia... gosto muito de documentários... especialmente documentários... brasileiros ou não... mas documentários que::: que concretizem aquilo que a gente está estudando né... então sempre faço uma seleção de documentários interessantes de...

filmes de arte que::: dizem respeito aos estudos que a gente está fazendo... levo muitos 
recortes de jornais e outros/invento algumas dinâmicas... apropriadas ali mas que tenham a intenção... de provocar a reflexão... a crítica... especialmente a participação deles né... ahn... em alguns momentos dou aula expositiva porque acho que isso também é meu papel... mas eu gosto muito que os alunos falem... eu acho que o fato de falar... ajuda a sistematizar um pouco as idéias né... uma outra coisa que eu faço éh::: bom tem uma carga de leitura grande meu curso né... até um pouco grande demais... eles falam... mas professora isso não é comum né... será que eu vou agüentar? ((falou rindo))... o pessoal mais de exatas fala... mas... nossa... imagina... eu não tenho o hábito... dói meu olho... eu fico com sono... umas coisas engraçadas... ((riu)) é que nós de humanas já estamos muito acostumados a ler muito né... mas eles agüentam bem... eles se entusiasmam pelas leituras... e a leitura é tão importante que::: que vale... nota no meu curso... então eu cobro resumos... né... resumos que não precisam ser resumos críticos... opinativos... mas resumos que sintetizem as idéias... defendidas ali::: no::: texto... né... como um instrumento de estudo mesmo né... e é interessante que nas avaliações que eu faço... avaliações do curso né... que eu faço com eles no meio... no final... eles acabam elogiando muito isso... essa exigência da::: da leitura e o retorno né... a importância de::: de ser considerado também um item da avaliação... uma outra coisa que parece banal mas que eu cuido muito éh::: o que eu chamo de contrato pedagógico... assim... alguns combinados que a gente faz logo no começo do curso... claro que isso tem que ser reiterado inúmeras vezes... mas acho que há uma cultura no ensino superior muito complicada que é assim... é como se o aluno já::: tivesse conquistado um grau de autonomia... né... que na verdade éh:.: fictício... né... éh::: e esse grau de autonomia muitas vezes é confundido com desrespeito... com abandono... né... e::: alguns alunos... eu vejo que se não entra nesse contrato... chegam a hora que querem na sala... vão embora a hora que querem... né... então a gente tem um combinado assim... tem uma tolerância de uns vinte minutos no início... mas quem chegar atrasado depois desse horário não entra na sala... né... e terminamos a aula juntos... eu fico realmente muito feliz... muito lisonjeada ((sorriu)) porque eu consigo esse FATO heróico ((falou com satisfação))... é não é controlando... punindo... dando/tirando nota... não é isso... é o contrato mesmo... no trato... no combinado... né... participar da aula... estar presente na aula... não é uma aula virtual... não dá para ser feita a distância... estar presente é muito importante... né... e contar com a participação de todos... e é interessante que eles ficam... eles chegam na hora... eles ficam até o final né... e isso é um fato assim... isso é raro... é uma cultura do desrespeito... eu acho... e:.: bom além desse contrato... acho que tem um compromisso mesmo de levar a sério esse trabalho... e isso eu faço com a intenção... eu faço um trabalho de sensibilização na verdade inicial... para a problemática educacional que existe lá fora... no país que a gente 
vive... que nem todos estão... devidamente sensibilizados para o fato de... que é ocupar esse lugar (que esse aluno) num curso de licenciatura numa unversidade pública? ... se preparando para ser professor... coordenador... diretor de uma escola brasileira né... ou atuar em instituições ou fundações não importa exatamente onde ele vai atuar mas o campo da educação está muito complicado no Brasil né... e aí eu procuro logo no começo do curso trazer dados mais estatísticos... artigos de jornais que falam dos problemas... da realidade brasileira que nem todos têm... a devida consciência né...e esse compromisso mesmo... do que é estar aqui... o que é se preparar para ser um bom profissional da educação né... e isso é uma coisa que eu costumo cuidar muito porque eu acho que::: com certeza afeta na qualidade da participação desse aluno né... enfim é isso... uma outra... ainda do ponto de vista do conteúdo que você me perguntou... eu trabalho bastante com... aqui a gente não tem o compromisso de fazer uma::: uma apresentação de todos os autores da ((citou sua disciplina)) né... então a gente não dá um pouquinho de ((citou alguns autores)) ... a nossa organização aqui é mais temática né... então em que sentido? ... cada professor tem a liberdade de montar seu curso... claro obedecendo alguns preceitos básicos... que esse conteúdo deverá contemplar né... mas... tem autonomia para montar esse::: esse programa né... especialmente se utilizando de autores que cada um de nós tem mais intimidade em nossa área de estudo e tal... então eu trabalho bastante na linha::: histórico-cultural... porque eu acho que a perspectiva histórico-cultural... ela inspira algumas visões para a educação muito interessantes né... especialmente enaltecem a importância da educação para a formação... do sujeito humano... e então o curso todo ele é montado... éh:.: vamos dizer... ele tem esse referencial teórico muito claro... da metade para o final tem uma certa visão mais... são temas um pouco mais aplicados à realidade lá fora né... (são) temas como a indisciplina na escola... a questão dos portadores de deficiência... alguns temas um pouco mais... éh::: relacionados a::: questões... candentes do (mundo) educacional... basicamente isso...

\section{Pergunta 3}

bom... a gente consegue sim mapear um pouco né... claro que cada aluno é um aluno e::: não dá para generalizar... mas é possível mapear um pouco o perfil sim né... então o pessoal de letras particularmente... costuma freqüentar muito os meus cursos... tem muita gente de letras... eu até brinco... "por que tanta gente de letras sempre e tal?" ... eles... uma vez me contaram que tem um ranking lá... na faculdade não sei... dos professores de licenciatura... que eles brincam... "fuja dessa... vai nessa que é boa..." sei lá... eu acho que assim... o pessoal de letras gosta da nossa abordagem... da abordagem histórico-cultural porque é uma área que 
mexe muito com linguagem... relações linguagem e pensamento e tal né... então eu acho que assim... eu não sei se as pessoas que vêm para o meu curso já vêm também com esse interesse... mas/como eu consigo mapear... são pessoas muito interessadas... muito interessadas... interessadas... de modo geral... na temática e interessadas em particular (quando) as discussões são mais focadas nessa relação de pensamento/linguagem que é um pedaço relativamente grande do meu curso... que tem a ver com esses pressupostos teóricos... além disso... éh::: eu acho que::: se comparado a outras/outros... alunos de outros cursos como por exemplo matemática... química... biologia... são alunos mais preparados para o estudo... mais habituados com a leitura... me parece né... não fariam aquele comentário que eu falei... não temos hábitos de ler... não lemos muito... não... ao contrário... alguns chamam a minha atenção porque são atualizados... assim... conseguem fazer... relações interessantes com diferentes campos... falam... na área do::: desenvolvimento da linguagem de criança... falam de pesquisas muito recentes que eu particularmente conheço mas eles também conhecem... então isso... me chama a atenção né... como trabalhos sobre ((citou alguns exemplos)) ... muitos fazem referência... sobre o estágio assim... eu acho que são textos mais bem acabados... porque assim... o estágio nosso consiste numa entrevista... com alunos... um ou dois alunos ou três... eles escolhem... e depois eles fazem um relatório e uma análise crítica desse depoimento que foi coletado... éh::: o pessoal de letras assim como história... ciências sociais costumam fazer análises mais densas e apresentar relatórios melhores elabora/mais... acho que redação melhor do que outras áreas do saber como essas falei... matemática... biologia... são textos... são alunos que cuidam melhor do texto... são alunos que têm uma redação acho que mais... sólida... mais... mais fluída... éh::: eu particularmente tenho boa impressão dos alunos de letras... mas não sei de te dizer... tem a ver com as experiências que eu tive... eu... por exemplo... atualmente eu tenho duas alunas... que eram minhas alunas de letras da licenciatura que hoje fazem mestrado comigo... são minhas orientandas... eram alunas que se destacavam muito por esse perfil que eu estou comentando né... assim... eu estranharia muito um aluno com esse perfil... em outras áreas como matemática... biologia... mas em letras é mais aceitável... isso costuma acontecer... eu acho que::: éh::: assim::: eu sinto um certo despreparo para discutir questões educacionais ((pausa longa)) ... mas isso é meio geral assim... não é restrito ao pessoal de letras né... mas eu acho que assim... há uma certa::: éh::: ((pausa longa)) ... imaturidade... uma certa ingenuidade quando trata de algum tema mais ligado ao mundo educacional... um certo despreparo... eu sinto... né... mas... nada que difira tanto dos outros né... é meio geral isso... exceto quando esse aluno já é professor... já está mais envolvido né... isso é um dado assim... são pessoas menos curiosas eu acho... menos 
interessadas em aprofundar... temas da educação... quer dizer... ficam mais circunscritos ao seu campo de interesse... me dá um pouco essa impressão... mas... um ponto a favor é que gosta muito de ler... então isso é bom né... o fato de ler... de consumir muita literatura... de conhecer os clássicos... acho que dá uma visão de mundo mais aberta... mais ampla né... mas frágil no campo educacional... é isso. 


\section{Aluno 1 - A1}

Pergunta 1

o curso de licenciatura para mim... em inglês éh::: metodologia foi uma surpresa... porque eu não imaginava que houvesse tanta ciência em dar aula... para mim era só chegar na aula abrir o livro e simplesmente abrir a boca e dar gramática né... no caso era o que eu fazia já há três anos numa ONG... que lecionava para pessoas... inglês... que não podiam pagar uma mensalidade uma coisa assim... e era muito prático porque... inclusive eu era tida como uma excelente professora porque seguia o método seguia o livro... inclusive um dos meus alunos disse assim o método é bom mas o professor tem que segui-lo... então você é bom ou ruim na medida que você segue o livro... porque é uma coisa que os alunos podem acompanhar... então não se tira nada de fora... e se enche lousas para que eles escrevam eles simplesmente acompanham exercícios no livro... até então eu pensava que essa era a maneira de dar aula de inglês... aí quando eu comecei a fazer a metodologia... do ensino do inglês eu vi que não era bem assim né... eu de fato nunca tive aula assim... eram aulas muito boas... mas eu nunca pensei que houvesse um planejamento assim... eu sempre pensei que era um dom que a pessoa tinha... que punha o pezinho na sala de aula... baixava um santo... um professor... e aí ele se transformava num bom professor de inglês que eu gostava de assistir... aí quando eu vi que tinha TODO um estudo... TODA uma seleção de métodos... que existiam métodos... assim determinados... dez métodos... doze... vinte que sejam... livros de acordo com determinada metodologia ou outra... aí eu vi... nossa ((exclamou)) ... havia inclusive uma evolução dessa metodologia ao longo da história... isso me deixou muito assim... primeiro... desapontada... porque eu tinha uma boa opinião sobre... mim e de fato não corresponde à verdade... de fato eu era uma professora horrorosa porque... não atendia principalmente a uma coisa chamada... students' needs... que é as necessidades reais dos alunos... nunca pensei nisso... pensei... bom se eu estou com o livro e os alunos estão aí é porque o livro diz o que os alunos precisam saber... então eu tinha uma crença tão grande no livro no método que eu não abria para outras coisas... então era uma aula muito quadradinha... e por incrível que pareça... essa aula agradava os alunos... talvez porque eles tivessem visto isso ao longo de sua vida... escolar e etc... só viram esse tipo de aula... como eu pude estudar em lugares bons né... ((citou escolas de idiomas))... eu via esse tipo de professor mediúnico né... que punha o pé na sala de aula e a aula saía... como se não houvesse preparo nenhum... com uma facilidade incrível... aí quando eu fui estudando na metodologia eu via que realmente é um trabalho insano de pesquisa... não é só simplesmente chegar e abrir o livro... numa sala de aula... você tem todo um 
planejamento... das necessidades do aluno em questão... que é uma coisa que eu nunca tinha aprendido a fazer... porque eu era meio a professora selvagem... chegava abria o livro e ((reproduziu som onomatopéico))... dar gramática... dá-lhe gramática... e era isso né... e foi uma surpresa... uma decepção porque eu me considerava boa... aí eu vi que não era boa... que era só::: regular né... e que eu posso melhorar... é nesse sentido que eu me vejo como aluna da licenciatura...

Pergunta 2

éh::: no caso... as atividades que eu acho que contribuíram... primeiro para um tomada de consciência... do quão ruim eu era... foi justamente a exposição da metodologia... do ensino de inglês como língua estrangeira ao longo do tempo... que eu pude ver uma evolução... e que as coisas são frutos de pesquisa séria... agora a coisa que está faltando e eu vou ter só no segundo semestre... é justamente dar um curso de inglês... com acompanhamento da professora que::: nós somos em duas alunas né... como eu tenho experiência... de ensino e a outra minha colega não tem... ela estará... a frente da aula e eu vou ficar... ajudando na elaboração da aula e discutindo como se faz o planejamento com ela... serão quinze aulas... que nós vamos planejar... ao longo de/a primeira aula ao longo de julho que seria justamente aquilo que eu não/que eu desconhecia antes né... a questão de você saber... detectar... diagnosticar as necessidades dos alunos... e o nível que eles estão... não só os que eles querem o que eles desejam... mas o que eles podem fazer com o que eles já têm... que é uma coisa que eu jamais me preocupei... isso é nossa primeira atividade... e:.: como eu falei antes... de fato... eu acho que está faltando justamente ESTA parte... para eu sentir na prática como se faz um curso de verdade... que é todo um preparo... porque nós temos aulas uma vez por semana... e o minicurso de inglês é também dado... uma vez por semana... antes da nossa aula... eu a minha colega vamos dar quinze aulas... só que ela estará a maioria do tempo na frente... e o problema é que eu não sei ainda como será porque eu já tomei a consciência que não é nada disso... você não abre simplesmente o livro... mas que há todo um planejamento... eu não sei como planejar ainda né... de onde eu pego as coisas... existe uma sala com materiais... que você pode... fazer uso e tal... mas eu ainda me sinto muito insegura quanto a isso... apesar de eu conhecer as metodologias... eu não sei por onde começar por exemplo com aluno que é um true beginner... ou um aluno que é um false beginner... antes eu nem tinha idéia do que era isso né... agora pelo menos eu posso distinguir essas duas categorias... mas de fato está faltando ainda ESSA... atividade com acompanhamento da professora... que agora será no segundo semestre... 
Pergunta 3

ah... eu acho que eu dei muita sorte... eu tive... excelentes professores na licenciatura... como essa é minha segunda licenciatura né... de fato a terceira porque eu faço português inglês... eu já havia feito a licenciatura em ciências sociais... então os professores que eu tive... todos na minha opinião... cooperaram... a coisa é::: talvez eu não tivesse maturidade suficiente para juntar tudo aquilo que eu aprendi nas diversas disciplinas da licenciatura... num (corpo) de ser professor... como eu me vejo professora com toda essa bagagem... eu não consigo fazer essa transição entre... todo esse conhecimento e o que eu posso fazer numa sala de aula... de fato é uma coisa que... não me passou ainda... pela cabeça... eu só estou tomando consciência dessa postura de ser professor... agora nessa licenciatura... de letras né... porque eu pude ver que a questão de sala de aula é sempre colocada... não é uma coisa que eu via por exemplo na outra licenciatura... de ciências sociais... eu não vi por exemplo um planejamento de aulas para a sociologia em/no ensino médio... isso eu não vi... eu conversei com um professor de sociologia... num colégio estadual quando eu fiz estágio... assisti algumas aulas... mas eu ainda senti que... éh::: não havia nada correspondente... na disciplina de licenciatura para ciências humanas... eu pude descobrir isso apenas agora na letras... que no meu entender há um preparo assim muito consciente... a pessoa quer dar aula... aqui estão os parâmetros... inclusive parâmetros curriculares... coisa que eu nunca ouvi falar... ouvi falar agora... e de uma maneira muito clara... não foi/a própria questão de você ir numa escola e fazer estágio... por exemplo de português e inglês me forçou a sentar numa mesa e copiar a MÃO muitos dos projetos pedagógicos da escola... que eu pude ver os parâmetros ali... corporificados... eu não tinha idéia do que eram objetivos gerais e específicos... até então... então eu pude aprender isso copiando o projeto pedagógico simplesmente... havia claro um seminário sobre isso mas eu acho que o seminário da sala de aula... fica uma coisa muito artificial... porque você só vê como é uma escola mesmo quando você está na escola... e esse dia coincidiu/houve uma coincidência muito interessante... eu estava copiando o projeto pedagógico... e parecia uma delegacia de polícia porque entraram dois policiais com cinco alunos... que foram pegos fazendo alguma coisa muito séria... porque ninguém disse o que era... eles foram expulsos imediatamente... os pais foram chamados... o pai de um deles começou a passar mal... foi assim... uma novela $(($ exclamou $)) \ldots$ durante as três horas que eu fiquei lá copiando... e é um colégio muito bom... assim... fica no centro de São Paulo... não é periferia... e me chamou a atenção muito para isso... inclusive com a conversa com a::: a coordenadora pedagógica de que de fato há coisas muito externas à escola que acabam interferindo demais no que acontece 
dentro... e isso eu vi especificamente na licenciatura de português... que a escola não é uma resposta para tudo que acontece... ela não pode ser uma panacéia... a escola tem uma finalidade específica... ela não pode resolver TODOS os problemas da sociedade... mas o problema é que... as pessoas de baixa renda vêem a escola como... a única maneira de ascender socialmente... pela instrução... então a questão ideológica é... se eu estudar se eu me dedicar eu serei alguém... só que o aluno presente... que eu pude perceber da escola... diz assim... "não vai adiantar nada eu me instruir porque será a mesma coisa... a mesma droga... entendeu?" ... então o que eu estou sentindo é que há uma diferença entre o que havia no passado... que é uma coisa que a gente viu em textos em sala de aula na licenciatura... uma expectativa que havia muito séria e muito ideológica também do sucesso... a idéia do sucesso através da instrução... da educação... que hoje os jovens... já percebem que... não adianta mais se educar tanto... eu já cheguei a ouvir numa aula de português... coisas do gênero... "ah o presidente Lula fez até o quarto ano e é presidente... por que que eu tenho que estudar?” ... coisas assim... claro que em tom de piada né... mas fica aquela mensagem de que... bom se você for esperto... não é preciso ter tanto conhecimento... então há outros valores que estão entrando que não mais a instrução... e que eu percebo isso nos alunos... se não fossem os alunos... e a minha presença na escola... eu jamais faria ligação de uma coisa com a outra... então eu acho que é fundamental nós estarmos na escola... os textos são bons... eu vejo as professoras da licenciatura... como pessoas que já sabem disso... porque elas fazem absoluta questão que o aluno vá para a escola e faça pelo menos vinte horas de regência... que é o caso de português... no caso de inglês... são trinta horas... mas o fato de elas terem essa consciência quando nós mostramos o relatório... discutimos o relatório... é como se elas já esperassem que a gente trouxesse esse tipo de informação para elas... então eu acho que é uma sociedade de segredo né... tipo... "espera um pouco minha filha... quando você for para escola você vai ver o que é... porque a gente está vendo a teoria” ... elas deixam bem claro isso... existe uma teoria... didática... pedagógica... que coloca o aluno... como um ser... que fica sentado na cadeira o tempo todo ouvindo né... interessado... às vezes não é bem isso... aliás na maioria das vezes não é nada disso... então cabe ao professor desenvolver criativamente... estratégias para chamar a atenção do aluno... eu vi isso acontecer em sala de aula... e é uma coisa que não se aprende no curso de licenciatura... essa coisa de você se jogar... conhecer o seu público... se identificar com ele de uma certa forma... que haja uma conexão... uma relação realmente interpessoal entre professor e aluno... que a gente vê um pouco em psicologia... mas não adianta nada... a teoria não vale se você não estiver na escola... por isso éh::: eu achei muito interessante a professora de português nossa... da licenciatura... deixar claro... que ela faz 
questão que o aluno esteja na escola e que a assistente dela iria ligar para a escola para ver se o aluno estava fazendo estágio... porque não vale nada nós lermos textos com experiências de terceiros... se a sua própria experiência fica negativada... você tem que ter essa experiência e depois que eu terminei o estágio... eu dei graças a Deus... eu sofri para fazer estágio... que eu tinha que fazer à noite... eram sessenta horas de português... trinta de inglês... mas valeu muito a pena... porque até mesmo as aulas de inglês eu pude aprender alguma coisa que eu não sabia que era o present perfect... sabe muito interessante... eu tive aqui no ((citou escola de idioma))... em vários cursos de inglês... mas a professora colocou de uma maneira assim que eu... não sei explicar... eu entendi o que ela quis dizer... porque ela contextualizou de uma forma não abstrata... porque eu acho... na minha opinião... quando ela juntou a teoria com o aluno... a teoria ganhou um corpo... ela não estava falando para um aluno do curso de inglês... estava falando para um aluno do ensino médio... então ela trouxe a teoria para o mundo desse aluno... e isso eu aprendi com a professora de inglês do colégio que eu fiz o meu estágio... não desmerecendo as nossas professoras da licenciatura... nem os professores do ((citou escola de idioma)) etc... mas é uma coisa que é fundamental... você estar numa situação limite que o aluno não está prestando atenção... está conversando... e cabe a você criar um interesse para que esse aluno preste atenção... e é uma coisa que não é ensinada na licenciatura... é uma coisa que você aprende no estágio... por isso eu sou muito entusiasta do estágio apesar da gente sofrer para fazer essas horas... eu fui muito bem recebida na escola... eu acho que a teoria não vale nada sem a prática... e o que eu pude perceber das minhas professoras da licenciatura é que elas deixaram muito claro... o texto é uma coisa... a teoria é uma coisa... quando você estiver na sala de aula você vai ver... criar de algum lugar o seu ser professor... entendeu? ... a teoria subjaz... porque faz parte do seu conhecimento... mas ao mesmo tempo... essa coisa muito pessoal de cada professor... é importante... e cabe a nós desenvolvermos isso na prática... e isso realmente foi importante em relação aos professores da licenciatura... eles deixaram bem claro... ninguém engana ninguém... foi muito claro... elas foram muito claras desde o começo... 